Ukrainian Association of Educational and Developmental Psychology Institute of Psychology at Szczecin University

\title{
Socialization
}

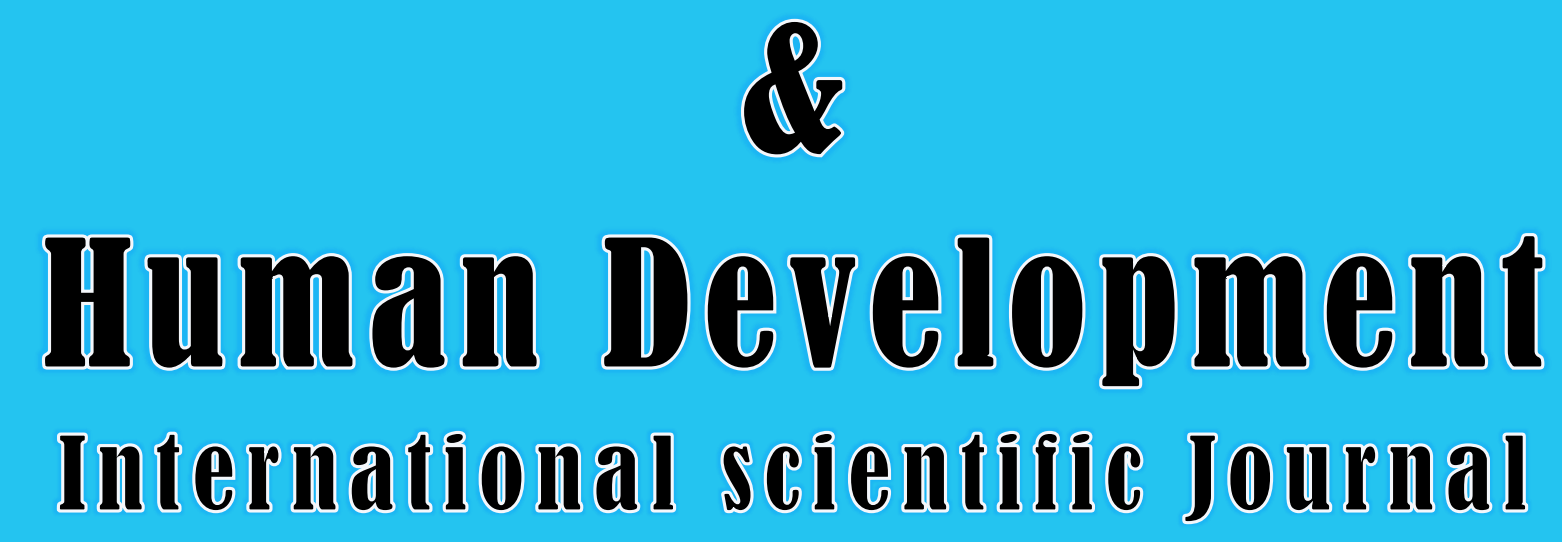

ISSN Online: 2706-8706

Uraine-Poland 


\section{"SOCIALIZATION \&}

\section{HUMAN DEVELOPMENT"}

\section{INTERNATIONAL SCIENTIFIC JOURNAL}

Kyiv-Szczecin 
"SOCIALIZATION \& HUMAN DEVELOPMENT" INTERNATIONAL JOURNAL

\section{Certificate ID: 925111839}

Issue 2 DOI: https://doi.org/10.37096/SHDISJ-20-1.1

Socialization \& Human Development: International Scientific Journal. Volume 2. №1 2020 / Kyiv Taras Shevchenko National University, University of Szczecin (Poland), Ukrainian Association of Educational and Developmental Psychology (Ukraine) - Szczecin, Kyiv, 2020.

The journal was launched in accordance with the founding agreement of Public Organization "Ukrainian Association of Educational and Developmental Psychology" (agreement dated apriele 02, 2019) \& Institute of Psychology at University of Szczecin, Poland.

\section{Executive editors}

\section{Editorial Board}

Editor-in-Chief (Ukraine) - Olena I. Vlasova, Dr. hab. of Psychology, Professor, Head of the Development Psychology Department at Kyiv Taras Shevchenko National University, Head of the Public Organization "Ukrainian Association of Educational and Developmental Psychology"; Coeditor-in-Chief (Poland) - Zdzistaw Kroplewski, Professor, dr hab. of Psychology, Director of the Institute of Psychology at Szczecin University Responsible Editor (Ukraine) -Natalia M. Dembitskaya, PhD, Assoc. Prof. of the Development Psychology Department of Taras Shevchenko National University of Kyiv; Responsible Editor (Poland).; - Celina Timoszyk -Tomczak, PhD, Assoc. Prof.; Creative editor - Vitaliy Lunyov, PhD of Psychology, Assoc. Prof. of the General Psychology Department, Kyiv National O.Bogomoltsya Medical University; Editor of the scientific papers in English - Svitlana Y. Paschenko - PhD of Psychology, Assoc. Prof., Kyiv National Taras Shevchenko University; Releasing editor - Mykola V. Maksymov - PhD of Psychology, Assoc. Prof. of the Development Psychology Department at Kyiv National Taras Shevchenko University (Ukraine).

\section{Editorial board members}

Pavel Boski - Dr. hab. of Psychology, Professor, Head of Department of Cross-Cultural Psychology Warsaw Faculty of Psychology at SWPS University (Poland) Tatyana M. Yablonskaya, Dr. hab. of Psychology, Sergey I. Yakovenko - Dr. hab. of Psychology, Professor, first vice-rector at Kiev Institute of Contemporary Psychology and Psychotherapy (Ukraine); Katerina L. Milyutina - Dr. hab. of Psychology, Professor of the Development Psychology Department at Kyiv Taras Shevchenko National University (Ukraine); Igor A. Furmanov, Dr. hab. of Psychology. Professor, Head of the Psychology Department at Belarusian State University. (Belarus); Manuele Shabus, Dr. Hab. in Psychology, Professor at the University of Salzburg (Austria); Dr. Matgorzata Szcześniak, Professor, of the Faculty of Psychology at Szczecin University (Poland), Maria Ligocka - Mr. of Psychology, assist. of Professor at Szczecin University (Poland), Leandro L. Di Stasi, PhD. of Psychology, assist. of Professor Mind, Brain and Behavior Research Center at University of Granada.(Spaine).

Publisher: Public Organization "Ukrainian Association of Educational and Developmental Psychology"Kyiv (Ukraine) http://www.UAPED.com

The publishers and editors do not accept responsibility for the expression of the authors in their writings which resulted from their research and personal beliefs.

(C) Authors of the Scientific Papers, 2020

(C) Ukrainian Association of Educational and Developmental Psychology, 2020

(C) Kyiv Taras Shevchenko National University, 2020

(C) University of Szczecin (Poland), 2020

(C) Editors: Olena I. Vlasova, Vitaliy E. Luniov, 2020 
"SOCIALIZATION \& HUMAN DEVELOPMENT" INTERNATIONAL JOURNAL

\section{CONTENTS}

1. Kolodych D., Zarzycka-Dertli J.E. DEVELOPMENT FEATURES OF EMOTIONAL INTELLEGENCE IN THE CONDITIONS OF INFORMAL EDUCATION (CROSS CULTURAL ASPECT)

2. Knyazev V.M. THE PECULIARITIES OF MENTAL DEVELOPMENT IN PRESCHOOL CHILDREN WITH ATTENTIVE DEFICIENCY SYNDROME WITH HYPERACTIVITY

3. Mambetova A. PSYCHOLOGICAL FEATURES OF DIFFERENT ETHNIC GROUPS' MALE REPRESENTATIVES WITH DIFFERENT CULTURAL MODES.

4. Molotokas A. FEATURES OF DEPRESSIVE DISORDER IN WOMAN DURING PREGNANCY

5. Onyshchenko V. M. FEATURES OF BEHAVIOR OF ADOLESCENTS FROM FAMILIES WITH DIFFERENT TYPES OF UPBRINGING AND PARENTHOOD ...

6. Prokopovych Y.M., Shykovets S.O. REFLEXIVE ABILITIES TO SELFREGULATION AS A COGNITIVE COMPONENT OF PERSONALITY'S PSYCHOLOGICAL WELL-BEING

7. Sadova M.A., Podshyvalkina V.I. DIFFERENCES IN PROFESSIONAL RESPONSIBILITY FOR STATUS AND ROLE IN THE WORKPLACE ............

8. Sedykh K., Metelska N. DYNAMICS OF DEVELOPMENT OF THE EDUCATORS' PROFESSIONAL SELF-CONSCIOUSNESS IN THE PROCESS OF PROFESSIONAL SKILLS IMPROVING

9. Shistko L.O., Riabchych I.Y., Prokopovych Y.M. EMPATHIC INTERACTION OF ADOLESCENTS: PSYCHOLOGICAL PECULIARITIES AND CORRELATES.. 96

10. Timoszyk-Tomczak C., Szcześniak M. "TIME FOR WISDOM" - THE RELATIONSHIP BETWEEN WISDOM AND THE TIME PERSPECTIVE ..........

11. Vlasova O. I., Kalenichenko K.M. THE EFFECTIVENESS OF THE PSYCHOLOGICAL SUPPORT PROGRAM OF THE PERSONALPROFESSIONAL GROWTH OF THE STATE EMPLOYMENT SERVICE OF UKRAINE PERSONNEL RESERVE

12. Yablonska T., Bulatevych N., Maksymchuk D. THE FEATURES OF ADOLESCENTS'S PERCEPTIONS ABOUT PARENTHOOD

13. Zapeka Y., Su Fey, Sirocha L. PECULIARITIES OF THE RELATED TYPE OF MOTIVATION AND ACADEMIC SUCCESS OF STUDENTS: CROSSCULTURAL ASPECT 
"SOCIALIZATION \& HUMAN DEVELOPMENT" INTERNATIONAL JOURNAL

\title{
DEVELOPMENT FEATURES OF EMOTIONAL INTELLEGENCE \\ IN THE CONDITIONS OF INFORMAL EDUCATION \\ (CROSS CULTURAL ASPECT)
}

https://doi.org/00.00000/SHDISJ-00-0.0-0000

\author{
Daria Kolodych \\ ORCID: 0000-0002-5960-9553 \\ Jolanta Ewa Zarzycka-Dertli \\ ORCID: 0000-0003-4651-8561
}

\begin{abstract}
The research involved 138 Ukrainian and 122 Vietnamese teenagers. The distribution of boys and girls was fairly uniform: there were 78 boys and 80 girls among, 63 boys and 59 girls among Vietnamese. The age of the respondents ranged from 11 to 15 years, the average age of the Ukrainian sample was 13.8, and the Vietnamese sample was 12.10. All children attended English language courses in small groups, were studied willingly and voluntarily. We used N. Hall`s EQ questionnaire to measure intra personal intelligence, interpersonal intelligence, understanding emotions, managing emotions and general level of emotional intelligence, which consists in all the mentioned elements. In addition, we examined the level of subjective control (J. Rotter's Locus of Control Scale test), lifestyle (The Life Style Index by R. Plutchik, H. Kellerman, and H. Conte (LSI)), professional inclinations (J. Holland's test), self-esteem in interpersonal relationships (Pip Wilson`s Blob Tree test). Revealed that emotional intelligence in teenagers affects their position in the team, professional inclinations, to some extent - the locus of control and defense mechanisms. There is a difference between Ukrainian and Vietnamese teenagers on interpersonal emotional intelligence and emotion recognition. Therefore, methods of teaching foreign language in Vietnam should include elements of acting, pay more attention to the definition of emotions. The ability to apply educational technologies aimed not only at learning, but also at the development of emotional intelligence, depending on the ethnic and cultural characteristics of children, should be included in the training program for foreign language teachers.
\end{abstract}

Keywords. Emotional intelligence, defense mechanisms, education, cross-cultural research.

\section{Introduction}

Nowadays there is an active development of informal education: courses, trainings, clubs and sections are becoming a common option for obtaining the knowledge necessary for further life and professional development. One of the distinctive options for information education has been foreign language courses that offer English to teens. The main focus (unlike school course in foreign language) focuses on the development of communication - the ability to freely express their thoughts, fluently speak and understand others. During this process, we believe, is the development of emotional intelligence, which was the subject of our study.

Previous studies analysis. In the context of globalization, the role of foreign 
"SOCIALIZATION \& HUMAN DEVELOPMENT" INTERNATIONAL JOURNAL

languages increases, because they actively acquire the status of a political, socioeconomic and cultural mechanism of international understanding in the world's community. This is due to several reasons, including:

- In the last decade, began to actively develop Ukrainian international relations with the European Union in various fields, such as business, education, social projects, lots of foreign companies, enterprises and organizations started to cooperate with Ukraine;

- The modern world has become more multinational and multilingual: on the one hand, the process of globalization and economic competition is intensifying, and on the other, the role of the national mentality is increasing;

- There have been changes in the labor market: almost everywhere requires professionals who have it-literacy and know at least one foreign language;

- society has become more mobile, enabling Ukrainian citizens to travel, study and work abroad [5].

The European pedagogical literature distinguishes three components of the educational system and it is generally accepted to use the following terms: formal education; - non-formal education; informal education [6]. For the first time, formal, non-formal and informal education was defined at the legislative level in Ukraine. Article 8 (Types of Education) of the recently adopted Law of Ukraine on Education provides:

1. A person uses his or her right to lifelong education through formal, nonformal and informal education. The state approves these types of education, creates conditions for the development of educational activities subjects that provide appropriate educational services and encourage education of all kinds.

2. Formal education is the education that is acquired according to educational programs in correspondence with certain levels of education legislation, disciplines specialties (professions) and provides specified standard educational results for learners relevant to their level of education and qualifications approved by the state.

3. Non-formal education - the education that is acquired usually by educational programs and does not include the awarding of state-approved educational qualifications by level of education, but could finish assigning professional and / or educational awarding partial qualifications.

4. Informal education (self-education) is an education that involves the selforganized acquisition by a person of certain competencies, in particular in the course of daily activities related to professional, social or other activities, family or leisure.

5. Learning outcomes gained through non-formal and / or informal education recognized in formal education system in accordance with the law. [5]

L. Moskalenko [3], as a result of a study of Ukrainians' involvement in information education, believes that the results of the study "Trends in the development of non-formal education in Ukraine" make a major conclusion - nonformal education has become a significant component of education in the country. It is advisable to further promote non-formal education and improve its effectiveness: to promote the concept of lifelong learning and non-formal education among different age, professional groups, with different levels of education; create conditions for establishing cross-sectoral partnerships in the field of non-formal education; create conditions for the spread of areas related to 
"SOCIALIZATION \& HUMAN DEVELOPMENT" INTERNATIONAL JOURNAL

informal education as a source of new jobs. O. Vlasova [2] considers the emotional intelligence development specifics of students, but only in Ukraine, and J. Breus [1] - the role of emotional intelligence in pedagogical education. S. Yablokov [7] draws attention to the importance of informal education in the foreign language learning process.

However, the problem remains unattended is informal teacher training education, including those who teach or plan to teach students from other cultures. Training future teachers in the theory and methods of teaching foreign languages should be carried out in general theoretical and methodological aspects. Postgraduate Education, which provides terminal foreign languages teachers training at the Institute of Postgraduate Education, should be based on the andragogical principles use. The foreign language teachers self-education importance should be emphasized. Their periodic training in the postgraduate pedagogical education system does not provide timely qualitative updating of professional knowledge, as the globalization process and educational technologies changes are rapidly developing. Therefore, one of the most important tasks of teachers' continuous education is self-developing skills that allow them to update theoretical knowledge and practical training to improve foreign language courses and its teaching methods independently. In addition, the vocational training of foreign language teachers should be proactive. Prepared in this way the teacher will be able to navigate changes in the concepts and content of the course, the new textbooks conclusion, teaching aids, preparing game- and training-style classes etc. Non-formal and informal education, which is not necessarily organized and systematic, can take place outside the traditional school and university education system and covers people of all ages. In this sector innovative approaches are most often applied, innovative teaching methods are tried. Foreign language teachers who have special access to modern information technologies and are interested in their widespread use, can actively use the opportunities of non-formal and informal education systems. In Ukraine, the existence of non-formal education covers the following areas: extracurricular education; postgraduate and adult education; civic education (diverse activities of NGOs); school and student self-government (due to the possibility of acquiring managerial, organizational, communication and other skills); educational initiatives to develop additional skills and abilities (computer and language courses, hobby groups, etc.). Recently Ukraine started to operate international language education projects.

Non-formal education can take place in any environment (school, family, church, community, etc.); at any age (from birth to death), which once again confirms the existence of non-formal education as part of lifelong learning; in individual or group form. Non-formal education can both complement and reinforce formal education, and contradict it, while remaining an important element that needs the necessary attention, study, implementation and use in the modern world to ensure a decent educational level for Ukrainian citizens. Thus, of particular relevance in our time become problems associated with the reform and development of the national system of continuous education of teachers, including foreign languages. It should be aimed at solving problems of professional and 
"SOCIALIZATION \& HUMAN DEVELOPMENT" INTERNATIONAL JOURNAL

personal development of teachers, specific activities and their range of functional responsibilities that are constantly changing.

However, the availability of informal education contributes not only to the knowledge acquisition as such, but also to the development of students and teachers' communicative competence and emotional intelligence. D. Goleman said: "What would have become of our school (and children), if the education program included the development of emotional intelligence capable of causing other people live feedback? Moreover, any employer would be happy to welcome such people into the ranks of their employees, those who have good competency in these life-important skills. This would also benefit the people themselves, which would result in partial elimination of social ailments - such as acts of violence, alcohol or drug abuse - that result from a lack of balance and self-control. The whole society would benefit from that - higher level of tolerance, care and personal responsibility would be a great boon for it"[3, p. 11].

J. Breus [1] suggested priority areas of emotional intelligence development during professional training in higher education institutions:

- understanding your own emotions and the emotions of others and as a result, the capacity for professional reflection, self-awareness as a person, as a professional, awareness of self-actions, behavior;

- self-control and self-regulation of emotions and as a result, the availability of personal professional identity, professional meanings (personal professional knowledge, professional attitude to the subject of work, professional ideals, norms and values, meaningful motives of professional activity);

- Awareness of their own emotions and management and, as a result, maintaining the health of the individual (physical, professional, psychological);

- The use of emotions, particularly in conflict situations and as a result, the ability to resolve conflicts in the professional activities and to sustain relationships with others (co-workers, supervisors, subordinates).

Some studies have shown that EI positively associated with quality of life, based on indicators of life satisfaction. The relation between EI, branching human social environment and social aspects of life satisfaction was found. A study of college students showed that a high level of EI indicators correlate with empathy and fewer conflicts, more interaction with peers. This suggests that EI is related to the social interaction quality. Similarly, a study of high-EI teenagers demonstrates their ability to manage other people's emotions successfully, potentially protecting them from negative emotions related to interpersonal communication.

Thus, we believe that the development of communication skills and emotional intelligence in the system of information education will promote a higher level of personal perception of their own well-being, as well as facilitate teenagers' transition to independent living and inclusion in new economically driven relationships in society. However, it should be noted that the researchers do not pay attention to ethnocultural features of the teenagers' emotional intelligence development, which is the subject of research in this article.

Therefore, the purpose of our empirical study was to compare the 
"SOCIALIZATION \& HUMAN DEVELOPMENT" INTERNATIONAL JOURNAL

emotional intelligence features of teenagers who are involved in the informal education system in Ukraine and Vietnam.

\section{Research methods}

The research involved 138 Ukrainian and 122 Vietnamese teenagers. The distribution of boys and girls was fairly uniform: there were 78 boys and 80 girls among, 63 boys and 59 girls among Vietnamese. The age of the respondents ranged from 11 to 15 years, the average age of the Ukrainian sample was 13.8, and the Vietnamese sample was 12.10. All children attended English language courses in small groups, were studied willingly and voluntarily. We used N. Hall`s EQ questionnaire to measure intra personal intelligence, interpersonal intelligence, understanding emotions, managing emotions and general level of emotional intelligence, which consists in all the mentioned elements. In addition, we examined the level of subjective control ( $\mathrm{J}$. Rotter's Locus of Control Scale test), lifestyle (The Life Style Index by R. Plutchik, H. Kellerman, and H. Conte (LSI)), professional inclinations (J. Holland's test), self-esteem in interpersonal relationships (Pip Wilson's Blob Tree test). This made it possible to identify links system between emotional intelligence level and its components with other mental symptoms, such as subjective control level, psychological defense mechanisms, types of professional inclination and the child s position in a group.

\section{Research results}

As a data obtained processing result, internal connections were found within the emotional intelligence test itself.

The interpersonal emotional intelligence indicator has the following correlative relations: average positive correlation with the scale Intra-personal emotional intelligence $\left(0.436^{* *}, \mathrm{p}=0.001\right)$; a strong positive correlation with Understanding Emotions (0.797 **, p = 0.000 ); average positive correlation with the Emotions Management scale $(0.578 * *$, $\mathrm{p}=0.001)$; a strong positive correlation with the Total Level of Emotional Intelligence $\left(0.831^{* *}, \mathrm{p}=0.000\right)$. The links with psychological defenses were interesting: this parameter was not related to most types of defense mechanisms, only the average negative correlation with Compensation was found $\left(-0.375^{* *}, \mathrm{p}=\right.$ 0.004). This means that the high level of interpersonal emotional intelligence person experiences less stress and does not use this type of psychological protection as compensation. It was also found links with professional inclinations: weak negative correlation with Realistic type $(*-0.262, \mathrm{p}$ $=0.049$ ); weak negative correlation with Convention type $\left(-0.330^{*}, \mathrm{p}=0.012\right)$; weak positive correlation with Artistic type $(0.276 *, p=0.038)$. Intra personal emotional intelligence indicator has the following correlation: a strong positive correlation with the Emotion Understanding Scale $(0.620 * *, p=0.000)$; strong positive correlation with the Emotion Management scale $(0.878 * *, p=$ $0.000)$; a strong positive correlation with the Total Emotional Intelligence $(0.863 * *$, $\mathrm{p}=0.000)$ scale. It was found a number of internal connections between emotional intelligence and personal self-esteem in interpersonal relationships: a weak negative correlation with Directivity ($0.267 *, \mathrm{p}=0.045)$; average negative correlation with Hostility $(-0.362 * *, \mathrm{p}=$ 0.006 ); a weak negative correlation with Inconsistency $\left(-0.296^{*}, \mathrm{p}=0.025\right)$. We could say that intra personal emotional intelligence makes teenagers less hostile 
"SOCIALIZATION \& HUMAN DEVELOPMENT" INTERNATIONAL JOURNAL

and more accommodating in interpersonal relationships. At the same time, unlike the previous variable, the intra personal emotional intelligence has a weak positive correlation with such psychological defenses as Denial $(0.272 *, \mathrm{p}=0.041)$; Intellectualization $(0.302 *, \mathrm{p}=0.023)$; average negative correlation with Regression $(-0.511 * *, p=0.000)$. This means that with the level of the first, second level decreases, and vice versa; weak negative correlation with the overall strength of defenses $\left(^{*}-0.270, p=0.042\right)$. This means that intra personal intelligence has no clear impact on the stress level and psychological defenses. In addition, this type of emotional intelligence has no significant effect on teenagers` professional inclinations. Emotion Understanding is related to: weak negative correlation with Inconsistency $\left(-0.336^{*}, \mathrm{p}\right.$ $=0.011)$; weak negative correlation with Regression (-0.269*, p $=0.043)$; weak negative correlation with Compensation ($\left.0.281^{*}, \mathrm{p}=0.034\right)$. This means that such indicator as understanding emotions reduces the overall tension of interpersonal relationships, reduces symptoms of psychological defenses. This is confirmed by a weak positive correlation of the parameter defined with the Interpersonal Relationship Internality $(0.282 *, \mathrm{p}=$ $0.033)$. This parameter is also associated with teenagers ' professional inclinations: it has an average negative correlation with the Convention type $(-0.349 * *, p=0.008)$; weak positive correlation with Artistic type $\left(0.334^{*}, \mathrm{p}=0.011\right)$.

While in the sample of Vietnamese students, the indicator "Understanding of emotions" is associated with a weak negative correlation with the psychological protection of "Suppression" (-0.293*, $\mathrm{p}=$ 0.028); and the parameter "Emotion
Management" is associated with a weak positive correlation with the "Internality of interpersonal relationships" $\left(0.338^{*}, \mathrm{p}=\right.$ 0.012 ). This means that together indicators such as understanding and managing emotions reduce the overall tension of interpersonal relationships and reduce the manifestations of suppression as a psychological defense.

Thus, we can predict that the emotional intelligence development will have a positive effect on teenagers' interpersonal relationships, reducing levels of conflict and force interaction. Emotional intelligence is particularly important for teenagers who are focused on the creative profession - the artistic type, and is not very necessary for those who are focused on conventional and economic specialties. The connection between emotional intelligence and psychological defenses is not one-way, and needs further study. In any case, we can consider that teenagers would benefit from the emotional intelligence development in such kind of informal education activity as English language courses. Another issue that arose in our study was the presence or absence of differences in the emotional intelligence development between Ukrainian and Vietnamese students. We tested the statistical difference between the sample scores by the average of the emotional intelligence of Ukrainian and Vietnamese children. For this purpose, we used the comparing averages $\mathrm{T}$-Student criterion according to the emotional intelligence questionnaire test.

Statistically significant differences were found in the following indicators:

Interpersonal emotional intelligence $($ Sig. $(2$-tailed $)=0.000)$, Intrapersonal emotional intelligence $($ Sig. $(2$-tailed $)=0.026)$, 
"SOCIALIZATION \& HUMAN DEVELOPMENT" INTERNATIONAL JOURNAL

- Emotions understanding (Sig. (2tailed) $=0.000$ ),

- Emotion management (Sig. (2tailed) $=0.005$ ),

- Total Emotional Intelligence level (Sig. $(2$-tailed $)=0.000)$.

Distribution of average scores for each scale shown in Table 1.

As shown in Table 1, the differences relate not all components of emotional intelligence: Intrapersonal emotional intelligence and emotion management had no significant differences, while the cultural features of Vietnamese culture led to a lower level of interpersonal intelligence and Emotions understanding. This can be explained by the fact that emotional restraint, the ability to regulate, and not openly demonstrate their own emotions were considered the norm of this culture.

Tab. 1. Average scores of teenagers`emotional intelligence.

\begin{tabular}{|l|l|l|l|}
\hline \multicolumn{1}{|c|}{ Indicators } & \multicolumn{1}{|c|}{ Ukraine } & \multicolumn{1}{|c|}{ Vietnam } & \multicolumn{1}{|c|}{$\begin{array}{l}\text { The } \\
\text { accuracy of } \\
\text { the } \\
\text { differences }\end{array}$} \\
\hline $\begin{array}{l}\text { Interpersonal Emotional } \\
\text { Intelligence }\end{array}$ & 43.35 & 33.36 & $\begin{array}{l}\text { There are } \\
\text { differences }\end{array}$ \\
\hline $\begin{array}{l}\text { Intrapersonal Emotional } \\
\text { Intelligence }\end{array}$ & 42.79 & 39.05 & $\begin{array}{l}\text { No } \\
\text { differences }\end{array}$ \\
\hline Emotions understanding & 43.6 & 33.82 & $\begin{array}{l}\text { There are } \\
\text { differences }\end{array}$ \\
\hline Emotion management & 43.75 & 39.25 & $\begin{array}{l}\text { No } \\
\text { differences }\end{array}$ \\
\hline $\begin{array}{l}\text { Total Emotional } \\
\text { Intelligence level }\end{array}$ & 86.14 & 72.41 & $\begin{array}{l}\text { There are } \\
\text { differences }\end{array}$ \\
\hline
\end{tabular}

Teenagers enrolled in foreign language courses focus on communication and work with people of different cultures and emotional restraint, the same as emotion recognition difficulties, may discourage these plans. Therefore, methods of teaching foreign language in Vietnam should include acting elements; pay more attention to the definition of emotions. The ability to apply educational technologies aimed not only at learning, but also at the emotional intelligence development, depending on the ethnic and cultural characteristics of children, should be included in the training program for foreign language teachers.

\section{Discussion}

In the study of the social skills and emotional intelligence development of Ukrainian teenagers, O. Vlasova (Vlasova, 2005) concludes, "the main determinants of the effective deployment of this complex and multidimensional process of the human psyche at the age of 11-12 are a significant increase in such students' attitudes to dominance in interpersonal contacts. We tend to consider such growth as a kind of socio-psychological equivalent of the formation of the subjectivity of these individuals as active carriers of the social "Self" of the individual, which defines itself through the reaction to its actions of 
"SOCIALIZATION \& HUMAN DEVELOPMENT" INTERNATIONAL JOURNAL

the reference environment of peers. Such a psychological situation primarily provokes the growth of its socio-emotional and socio-conative properties associated with the further active formation of the operational component of the relevant social skills in terms of formation of emotional standards of facial expressions and adaptive strategies for adequate response in conflict, emotionally charged situations of frustration. An important role in the formation of the optimal communicative style of younger tennagers is played not only by mastering socionormative patterns of behavior and evaluation of others, but also the general attitude of people of this age to active communication with peers, responsible attitude. The development of their own causal-attributive and speech properties, which goes hand in hand with the general intellectual development of such persons, puts these skills at the center among the mechanisms of their socio-psychological self-realization, as it allows to have an effective influence on the reference community of classmates, as eloquently evidenced by the associated growth of their social status". In our study, we found less desire of Vietnamese students to dominate, and lower levels of emotional intelligence, which confirms the results obtained by $\mathrm{O}$. Vlasova. This suggests that classes aimed

\section{References}

1. Breus J. Emotional component in the structure of higher education / YU. V. Breus // Humanitarni aspekty formuvannya osobystosti : Zbirnyk statey VI Vseukrayins'koyi naukovoyi konferentsiyi, 27 kvitnya 2012 r. - L'viv : LDU BZHD, 2012. - S. 277-287 at developing active communication in English classes and the creation of a reference community in informal education will contribute to the formation of students' social skills.

\section{Conclusions}

Emotional intelligence in the teenagers affect their position in the group, professional inclinations, to some extent the locus of control and psychological defenses. There is a difference between Ukrainian and Vietnamese teenagers on interpersonal emotional intelligence and emotion recognition. Therefore, methods of foreign language teaching in Vietnam should include elements of acting skills, with greater emphasis on the emotions definition. The skill to apply educational technologies aimed not only at learning, but also at the emotional intelligence development, depending on the ethnic and cultural characteristics of children, should be included in the training program for foreign language teachers. For Ukrainian teenagers, whose development of emotional intelligence was associated with professional aptitudes, we consider it appropriate to provide additional vocational guidance classes aimed at strengthening creative skills, which will allow starting training of high-level professionals earlier.

2. Vlasova O. I. Psychology of development of social abilities of the person in ontogenesis [full ontogenesis]: scientific monograph. / O.I. Vlasova. - Ottawa: Accent Graphics Communications, 2019. $377 \mathrm{~s}$.

3. Goulman D. Emotional Leadership: The art of managing people based on emotional intelligence / Deniyel 
Goulman, Richard Boyatsis, Enni Makki. - M. : Al'pina Biznes Buks, 2007. - 301 s.

4. Moskalenko L. M. Trends in the development of non-formal education in Ukraine (according to the results of a sociological survey). VISN. L'VIV. UN-TU VISNYK LVIV. UNIV. Seriya sotsiol. 2018. Vyp.12. S. 212220, Ser. Sociol. 2018. Is.12. P. 212 220

DOI: http://dx.doi.org/10.30970/vso.2018 $.12 .12 /$

5. Law of Ukraine "On Education" (2017). Retrieved from: http://zakon0.rada.gov.ua/laws/sho w/2145-19

6. Recommendation of the EU Council on the recognition of non-formal and informal learning. Режим доступу: http://ipq.org.ua/upload/files/files/0 6_Biblioteka/01_Normativna_baza/ 01_Viznznnya_neformalnogo_navc hannya/01_Mignarodni_dokumenti/ council_recommendations $20 \mathrm{~d}$ ec $201 \overline{2}$ ukr.pdf (Recommendation of the EU Council on the recognition of non-formal and informal learning)

7. Yablokov S. Integration of formal, non-formal and informal learning in English language teaching // Pedahohichni nauky: teoriya, istoriya, innovatsiyni tekhnolohiyi, 2018, № 1 (75) 106-116; ORCID ID 0000-0002-3018-1231 DOI $10.24139 / 2312-5993 / 2018.01 / 106-$ 123. 
"SOCIALIZATION \& HUMAN DEVELOPMENT" INTERNATIONAL JOURNAL

\title{
THE PECULIARITIES OF MENTAL DEVELOPMENT IN PRESCHOOL CHILDREN WITH ATTENTIVE DEFICIENCY SYNDROME WITH HYPERACTIVITY
}

https://doi.org/00.00000/SHDISJ-00-0.0-0000

Knyazev V. https://orcid.org/0000-0001-9599-7429

\begin{abstract}
Annotation
The article is devoted to the analysis of the peculiarities of the early manifestations of attention deficit with hyperactivity disorder (ADHD) in preschool children. The topic of ADHD requires a detailed psychological analysis. Such work will allow the formation of methodological and theoretical tools, the need for which is now felt by the practical psychologists. The following research methods have been used: theoretical analysis, generalization of scientific approaches, theoretical modeling, symptomatic analysis. Based on the data obtained, a unified theoretical and methodological model has been developed that allows to carry out the comprehensive analysis of the developmental features of preschool children.

The analysis of the developmental features of the child in the early stages of ontogenesis can be carried out along several axes, which go through several stages of their formation, which are accompanied by dynamic changes such as interfunctional relationships and the child's worldview is shown. A comparison of the results of studies of the features of the early stages of children development with ADHD has allowed to expose a deficit axis of development, changes in the formation of which lead to the appearance of children's behavioral disorders of such a group. The peculiarities of the passage of the axes development in the process of ontogenesis also makes it possible to identify the mechanisms of their correction and habilitation, which has undoubted practical value. At the moment, this integrative model has already shown its practical value. A number of correctional development programs, as well as support programs, have been worked out. The results of empirical studies show their high efficiency. In addition, the model demonstrates its high efficiency in advising family members and child support groups, in particular, when conducting psycho-educational work.

Key words: attention deficit hyperactivity disorder, diagnosis, integrative model, psychological correction methods, preschool age, early intervention.

\section{Introduction}

Being one of the most common problems of childhood development, attention deficit hyperactivity disorder is a comorbid disorder characterized by a combination of a large number of various symptoms. Moreover, various approaches aimed at correcting and abilitating developmental deficiencies interpret the

causes of this symptomatology in different ways, often using descriptive models that are different from each other. However, practical experience shows the need to describe the developmental features of children with ADHD from the standpoint of a single theoretical and methodological model that can integrate existing data into itself, while remaining open for further
\end{abstract}


"SOCIALIZATION \& HUMAN DEVELOPMENT" INTERNATIONAL JOURNAL

changes. Such a model can be built only on the basis of a thorough analysis of the existing at the time data on the causes and characteristics of the manifestation of ADHD symptoms in children of different age and social groups.

According to existing data, manifestations of pathological symptoms in children with attention deficit hyperactivity disorder are especially intense in periods from 5 to 10 years, which corresponds to the initial stages of a child's schooling, as well as from 12 to 15 years (Rumyantseva V. M. 2003). However, the first manifestations of this symptomatology can be fixed already in the younger preschool age. However, during infancy, as well as in the preschool period, the pathological symptoms characteristic of children with ADHD manifest themselves in a slightly different way. In children, sleep disturbance, difficulties in interacting with various sensory stimuli, which manifest themselves as hypo- and hypersensitivity, motor awkwardness, a slight delay in speech development, are observed (Bundy A. 2017). Moreover, in children of primary school age, the symptoms of ADHD may coexist with asthenic manifestations, which are combined with various learning difficulties (Sirotyuk A.L. 2002). This heterogeneity of symptoms at different stages of the development of a child with ADHD is interpreted differently within the framework of biomedical and sociopsychological models, leading to insufficient consideration of various factors in the organization of correctional work.

The relevance of the request for the development of a unified model that allows us to describe the child's development process taking into account possible developmental deficiencies is increasing due to the need for an environmentally valid and effective corrective and therapeutic intervention. Without pretending to paradigm, the proposed theoretical and methodological model is designed to facilitate the process of practical work of specialists in the field of psychological correction, rehabilitation and consultation.

The object of the study: child development.

The subject of the study: the regularities of the formation of higher mental functions of HMF in pre-school children with attention deficit hyperactivity disorder (ADHD).

The purpose of the study is a theoretical analysis of the researches of the symptoms development of ADHD in preschool children; theoretical analysis of existing periodizations of the development of the psyche in ontogenesis; the formation of an integrative theoretical and methodological model; comparing the data obtained on the features of the early manifestation of symptoms of ADHD with the stages of the development of the psyche in ontogenesis; the exposure of the main directions of corrective intervention during the work of ADHD in pre-school children.

The research methods: theoretical analysis of the mental development of preschool children with ADHD; generalization of V.V. Lebedinsky, D. B. Elkonin, J. Piaget's scientific approaches describing the characteristics of the development of the psyche in ontogenesis; theoretical modeling of an integrative approach to the analysis and correction of ADHD; symptomatic analysis of the manifestations of attention deficit hyperactivity disorder in pre-school children. 
"SOCIALIZATION \& HUMAN DEVELOPMENT" INTERNATIONAL JOURNAL

At this moment ADHD is one of the most common disorders in childhood. According to the studies, the symptomatology characteristic of this syndrome is observed in approximately 2 $18 \%$ of children (Rowland, Lesesne, \& Abramowitz, 2002). Early manifestations of such symptoms can lead to significant behavioral difficulties, which in turn can become an obstacle to the development of academic and social skills. In addition, neuropsychological deficits characteristic of this group of children can lead to underdevelopment of regulatory processes, which, in turn, are a necessary component in the structure of any higher mental function (Semenovich A.S., 2002).

In most cases, the diagnosis of ADHD is given to children of primary school age, and, most likely due to reinforcement in pathological manifestations against the background of a sharp increase in workloads, difficulties in organizing work in the classroom, which is exacerbated by a lack of understanding of the causes of problem behavior by teachers, parents and the child himself/herself.

According to the studies of children with ADHD symptoms in the pre-school period, the levels of inattention, as well as manifestations of hyperactivity impulsivity are often high, but there is significant variability with respect to the symptoms peculiarities in children (Lahey BB, Lee SS, Sibley MH, et al., 2016). In particular, it was shown that the intensity of pathological manifestations decreased with age, however, such a feature was more characteristic of symptoms of inattention than manifestations of impulsivity and hyperactivity.

The results of the studies by Leopold et al., show (Leopold DR, Christopher M.E, Burns G.L et al., 2016) similar results.
However, in the framework of this study, a decrease in the degree of intensity of the symptoms of hyperactivity was revealed, while the severity indicators for the symptoms of inattention remained unchanged.

The significant difficulty in researching the features of the early manifestations of ADHD is due to the fact that such behavioral features as a high level of motor activity, impulsivity, difficulty with maintaining and switching attention are normative manifestations for preschool children. The studies in this area show that in pre-school age for children with attention deficit hyperactivity disorder concomitant disorders are also typical. One of the most common is oppositional disorder, anxiety disorder, and communication disorder (Egger, et al., 2006; Posner, et al., 2007). The latter is of particular interest, since it is through interaction with the socio-cultural environment in the process of ontogenesis the gradual formation of higher mental functions occurs, which at the time of birth are present in the child only in the form of potential for development (L.S. Vygotsky, 2005). It has been shown that children with ADHD have difficulty constructing a communication act due to the insufficient amount of information they provide during the interaction (Nilsen et al., 2015), as well as difficulties in organizing the interaction process taking into account the social context (Landau and Milich, 1988). In addition, it has been shown that children with ADHD experience significant difficulties in understanding social cues and emotional distinction, even more significant than children with autism spectrum disorders (Downs and Smith, 2004). To this it is worth adding outbreaks of aggression and difficulty maintaining the 
"SOCIALIZATION \& HUMAN DEVELOPMENT" INTERNATIONAL JOURNAL

distance during the interaction, which are often observed in children with hyperactivity and attention deficit.

The data about the peculiarities of the development of cognitive sphere in children with problems of attention and motor disbraking show that differ psychological functions in pre-school period suffer insignificantly. The main reason of slow information memorizing, complication with keeping attention is the problems of arbitrary activity. (L. S. Vigotsky, I. I. Kravtsova, I. L. Horlova, et all). There is little data on the features of the development of the motivational sphere and game activity in this category of children, however, it can be supposed difficulties with behaviour regulation and keeping attention which lead to instability, hamper the development of the game activity. Such developmental features can be further enhanced by peer rejection (Landau et al., 1998).

Thus, despite the significant variability in the symptoms of ADHD in pre-school age, as well as the difficulty of identifying them in children of this age group, difficulties in controlling behavior and inattention can be identified as the main markers of pathological symptoms (Barkley, 1997). However, the additional deficits that often accompany ADHD in the pre-school period are also of considerable interest, as they may indicate additional ways of influence when organizing corrective work. For this purpose, it is necessary to compare the obtained data with the main stages and features of the development of the psyche in ontogenesis. Such work seems more productive if there is a single integrative model of the development of the psyche in ontogenesis.

To form a single integrative model of child development, three periodizations of child development have been analyzed. As the initial periodizations have been selected:

1. Periodization of levels of emotional development according to V.V. Lebedinsky

2. Periodization of intellectual development by J. Piaget

3. Periodization of mental development according to D.B Elkonin.

For the analysis and subsequent integration, the stages of the above periodizations of development corresponding to the age period from 0 to 7 years have been distinguished. As a result of the analysis, three integrative levels of development have been identified, where all data on the characteristics of the development of the child have been grouped in four axes:

1. Axis A - regulatory processes

2. Axis B - cognitive processes

3. Axis $\mathrm{C}$ - leading motivation

4. Axis D - relation to the world

The first level covers the time period from 0 to 1 year. The following periods from the analyzed development models correspond to it:

1. Model levels of emotional development according to V.V. Lebedinsky:

- level of assessment of the intensity of environmental impacts;

- level of affective stereotypes.

2. Periods of intellectual development according to J. Piaget:

- stage of sensorimotor intelligence (private stages 1 $3)$. 
"SOCIALIZATION \& HUMAN DEVELOPMENT" INTERNATIONAL JOURNAL

3. Development levels for the periodization of the mental development of D. B. Elkonin:

- the era of early childhood.

The second level covered the period from 1 year to 3 years. It is corresponded with:

1. Model levels of emotional development according to V.V. Lebedinsky:

- level of affective expansion;

- level of affective attachment.

2. Periods of intellectual development according to J. Piaget:

- stage of sensorimotor intelligence (private stages 46).

3. Development levels for the periodization of the mental development of D. B. Elkonin:

- the era of early childhood.

The third level corresponds to a time period of 3 to 7 years. It is corresponded with:
1. Model levels of emotional development according to V.V. Lebedinsky:

- the level of symbolic regulation of emotional processes.

2. Periods of intellectual development according to J. Piaget:

- stage of preoperative thinking.

3. Development levels for the periodization of the mental development of D. B. Elkonin:

- the era of childhood.

The results obtained by grouping the data along the axes are presented in the tab 1 .

In the proposed table, the axes $\mathrm{B}, \mathrm{C}$, and D are intrapsychic, and show the process of gradual formation in ontogenesis of the main structural components of the child's psyche. Axis A is more relevant to the extrapsychic level and shows how the nature of the interaction between the child and the world changes in the process of individual development. 
"SOCIALIZATION \& HUMAN DEVELOPMENT" INTERNATIONAL JOURNAL

Table 1.

Stages of the development of the psyche in ontogenesis

\begin{tabular}{|c|c|c|c|c|}
\hline & Axis A & Axis B & Axis $\mathrm{C}$ & Axis D \\
\hline 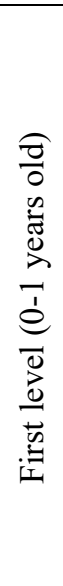 & $\begin{array}{l}\text { regulation of emotional } \\
\text { and physical states } \\
\text { through interactions with } \\
\text { the parent; } \\
\text { self-regulation of own } \\
\text { states due to cyclically } \\
\text { repeating rhythmic } \\
\text { patterns; } \\
\text { formation of an optimal } \\
\text { level of activation due to } \\
\text { the integration of } \\
\text { multimodal sensory } \\
\text { signals. }\end{array}$ & $\begin{array}{l}\text { assessment of sensory } \\
\text { influences on the } \\
\text { principle of "many-few"; } \\
\text { reflex integration; } \\
\text { basic motor skills; } \\
\text { breeding goals and } \\
\text { means of it achieving. }\end{array}$ & $\begin{array}{l}\text { direct emotional } \\
\text { communication with an } \\
\text { adult. }\end{array}$ & $\begin{array}{l}\text { passive interaction with the } \\
\text { world, dependence on } \\
\text { sensory environmental } \\
\text { signals; } \\
\text { "Merging" of the child } \\
\text { with the mother; } \\
\text { fixation on the physical } \\
\text { and bodily aspects of the } \\
\text { self. }\end{array}$ \\
\hline 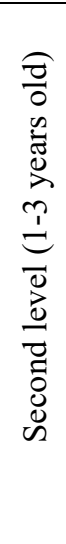 & $\begin{array}{l}\text { regulation of emotional } \\
\text { states and behavioral } \\
\text { patterns by the parent as } \\
\text { an external helping } \\
\text { object; } \\
\text { self-regulation of the } \\
\text { emotional state through } \\
\text { interaction with the } \\
\text { environment (according } \\
\text { to the principle of } \\
\text { emotional swing); }\end{array}$ & $\begin{array}{l}\text { assessment of } \\
\text { environmental impacts } \\
\text { on the basis of the "like- } \\
\text { dislike" principle; } \\
\text { the use of tools in } \\
\text { interaction with the } \\
\text { world; } \\
\text { interiorization and } \\
\text { combination of } \\
\text { previously mastered } \\
\text { behavioral and cognitive } \\
\text { patterns. }\end{array}$ & $\begin{array}{l}\text { interaction with the outside } \\
\text { world and objects as social } \\
\text { tools. }\end{array}$ & $\begin{array}{l}\text { the development of the } \\
\text { world around through } \\
\text { targeted interaction with it; } \\
\text { increase the degree of } \\
\text { separation of the child; } \\
\text { fixation on environmental } \\
\text { objects. }\end{array}$ \\
\hline 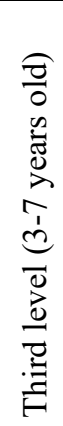 & $\begin{array}{l}\text { self-regulation of } \\
\text { emotional states through } \\
\text { game activity; } \\
\text { internalization of norms } \\
\text { and rules of behavior in } \\
\text { society. }\end{array}$ & $\begin{array}{l}\text { formation of a system of } \\
\text { integrated actions } \\
\text { (operations); } \\
\text { development of the } \\
\text { ability to generalize and } \\
\text { categorize; } \\
\text { forming an image of } \\
\text { yourself and an internal } \\
\text { picture of the world. }\end{array}$ & role-playing game. & $\begin{array}{l}\text { interaction with the world } \\
\text { indirectly by a system of } \\
\text { norms and rules of } \\
\text { behavior; } \\
\text { world as an "information } \\
\text { space". }\end{array}$ \\
\hline
\end{tabular}

Based on the data given in the table, an integrative model for the development of a pre-school child has been formed (Figure 1). 


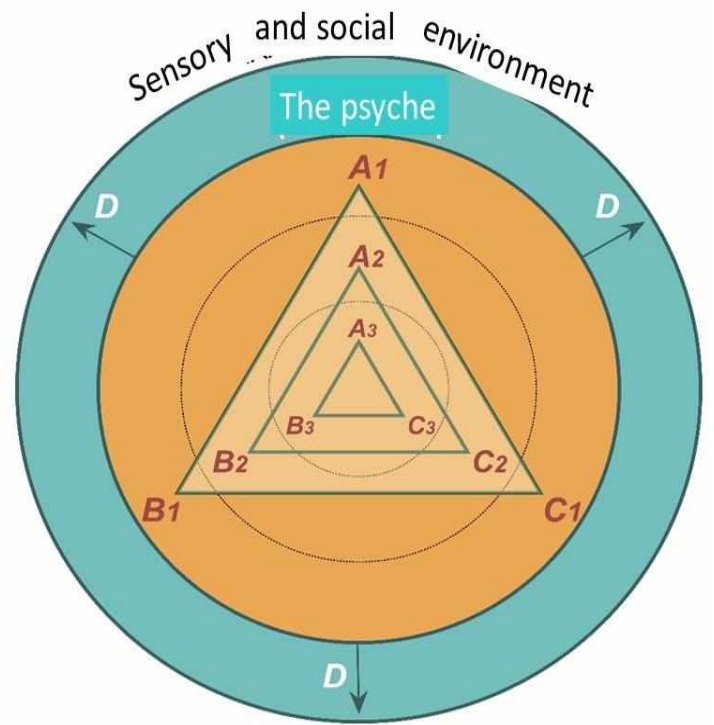

Note: A1, A2, A3 - symbols of the regulatory axis, respectively, the features of its development at various stages of ontogenesis.

B1, B2, B3 - symbols of the cognitive axis, respectively, the features of its development at various stages of ontogenesis.

C1 C2 C3 - symbols of the motivational axis, respectively, the features of its development at various stages of ontogenesis.

D - axis of the relationship of the child to the world

Fig. 1 Integrative model of a pre-school child development

This model is based on the categorical net of modern scientific knowledge. As the main meta-ontological categories on which the network model is based, one can pick out (M. M. Semago, N. Ya. Semago, 2011 p. 18):

- triad analysis;

- synchronism (dynamic harmony) of all forming, developing structures;

- fractality (self-similarity, holography) of analyzed constructs;

- measure (nature and dynamics of structural changes in the system and its elements).

Taking into account the principles of formation of HMF in ontogenesis, proposed by L.S. Vygotsky, as well as the data given in the table, three stages in the development of the psyche of pre-school children have been identified:

\section{Sensory-power}

- $\quad$ significant dependence on signals of sensory environmental influences;

- fixation on the body and its reactions;

- regulation of the intensity of sensory signals;

- external loci of behavior control;

- fixed rhythmic complexes;

- regulation of visceral processes;

- energy supply and involuntary regulation.

2. An affective-behavioral

- the formation of detailed behavioral patterns;

- affective interpretation of environmental influences;

- interaction with external objects, as with social tools;

- purposeful behavior;

- expansion of the emotional repertoire.

3. Cognitive regulatory 
"SOCIALIZATION \& HUMAN DEVELOPMENT" INTERNATIONAL JOURNAL

- self-regulation through the operation of images and symbols;

- formation of an internal locus of control;

- cognitive information processing;

- data integration of lower levels;

- orientation to the information space.

In figure 1 it is shown how the selected stages are related to the regulatory (A), cognitive (B), motivational (C) axes, which belong to the intrapsychic space, as well as the extrapsychic axis (D), which characterizes the changes in the child's attitude to the world and is determined by a set of indicators of the first three axes. In the form of a formula, it can be represented as follows $\mathrm{D}=(\mathrm{A}+\mathrm{B}+\mathrm{C})$ : 3 . Thus, the changes in the development of one of the intrapsychic axes will lead to a disruption in the process of implementing leading activities by the child, which in turn can lead to a disruption in the process of interaction of the child with the world. Based on this, it can be assumed that in the process of comparing the current level of development with indicators on each axis, taking into account the main stages of their formation, it is possible to identify the area of main deficit.

In addition, when the theory of dissipative systems is taken into account, in the context of its consideration by psychological science, the proposed theoretical and methodological model makes it possible to influence the most preserved development axes, if it is impossible to stabilize the deficient axis, or in parallel with this. It is due to the following features of the psyche as a complex system (Zinchenko Yu.P., 2012; Klochko V.E., 2013):

- openness;
- constant interchange with the environment;

- disequilibrium state;

- the need for external influence to change its state.

\section{Discussion}

The described approach potentially appears to be much more effective than the models that individual psychological schools offer. Based on the data on the peculiarities of development of HMF functions in ontogenesis and proposing for analysis 4 axes of the child's development, it allows overcoming the conflict between psychosocial and biologizing models of ADHD (Frances A., 2016), supplementing the available data on the influence of biological and social factors with a model exclusively psychological, which suggests both the importance of the process of interaction of the child with the environment, and biological factors. A similar model also implies the possibility of revealing the structure of a defect by comparing the level of development of both the intrapsychic and extrapsychic axes. In addition, it becomes possible to identify the trajectories of the development of symptoms taking into account age-related dynamics (Biederman J, Mick E, Faraone S.V., 2000), identifying the area of actual and immediate development. It makes possible to effectively introduce non-drug methods of stabilizing the child's condition, which are recommended as the most desired pre-school children (Fiks A.G, et al, 2016). Given the multifactorial nature of the ADHD problem in childhood, an approach that allows us to analyze the individual characteristics of the "developmental drama" of a child, taking into account its individual and personality characteristics, seems to be potentially more effective than methods designed to 
"SOCIALIZATION \& HUMAN DEVELOPMENT" INTERNATIONAL JOURNAL

work with groups (Edward G. Feil, et al, 2016).

On the basis of the proposed integrative scheme, correctional and developmental programs for children with ADHD of preschool age are developed. In the process of such work, the model has showed its significant practical value, acting as a support in analyzing the structure of the defect, identifying targets and goals when writing correction programs, conducting psycho-educational work with family members and educators.

There is no doubt that the theoretical analysis which has been proposed here requires studies showing the effectiveness of this model in its practical application. The model requires further development and additions, through analysis of research results of developmental features and the use of various methods of non-drug correction, when working with attention deficit hyperactivity disorder in pre-school children. Also, as a promising direction for the development of the proposed model, the integration of the elements of the neuropsychological model, with their translation into the language of developmental psychology comes forward. In particular, the concept of a neuropsychological factor, symptom, syndrome, the concept of irregular development, and a number of others may be of interest. The model of the neuropsychological factor with its hierarchy, features of vertical and horizontal organization, division into "rigid" and "flexible" links, as well as its definition as a modus operandi of individual mental processes, is of most interest here. The integration of this concept seems to be the most obvious of the following steps to improve the integrative model.

\section{Conclusions}

The comparison of data on the developmental peculiarities of children with ADHD in the pre-school period with an integrative psyche developmental scheme in ontogenesis gives us the opportunity to identify the main levels and areas of work in organizing the correction.

In this case, axis A acts as the main target of correction, its components at the sensory-energy level. This deficit, most likely, leads to secondary deficits of the B and $\mathrm{C}$ axes at an affectively behavioral level. The complex of primary and secondary defects leads to disruption of the process of interaction with the world.

The concept of allostasis (Sabbah W, Watt R.G, Sheiham A, Tsakos G., 2008) gives us the opportunity to move on to a new model for the organization of correction. This model indicates the possibility of obtaining positive changes in the condition of the child by affecting various components in the structure of the defect. This approach seems quite promising, as it allows you to organize work with the child, taking into account its individual characteristics, as well as the characteristics of the social development situation. Reliance on an integrative development scheme also allows not only to identify areas of impact, but also to identify areas of current and immediate development.

This topic requires further deep study. A promising direction for the further development of this topic is the creation on the basis of existing models of a unified integrated program for accompanying children with ADHD. 
"SOCIALIZATION \& HUMAN DEVELOPMENT" INTERNATIONAL JOURNAL

\section{References}

Bandy A. Sensornaia yntehratsyia / Anyta Bandy, Shelly Lein, Эlyzabet Miurrei;

per. [s anhl.] y nauch. Red. D.V. Ermolaeva. (2017). - M.: Terevynf. - 786 s. - ICBN 978-5-4212-0411-4. [in Russian]

Barkley RA. (1997). Behavioral inhibition, sustained attention, and executive functions: constructing a unifying theory of ADHD. Psychological Bulletin. 121:65-94.

Biederman J, Mick E, Faraone SV. (2000). Age-dependent decline of symptoms of attention deficit hyperactivity disorder: impact of remission definition and symptom type. Am J Psychiatry. 157: 816-18.

Downs A, Smith T. (2004). Emotional understanding, cooperation, and social behavior in high-functioning children with autism. J Autism Dev Disord. 34(6):625-635.

Edward G. Feil, Jason W. Small, John R. Seeley, Hill M. Walker, Annemieke Golly, Andy Frey, and Steven R. Forness. (2016). Early Intervention for Preschoolers at Risk for Attention-Deficit/Hyperactivity Disorder: Preschool First Step to Success. Behav Disord. 41(2): 95106.

Egger HL, Kondo D, Angold A. (2006). The epidemiology and diagnostic issues in preschool attentiondeficit/hyperactivity disorder: A review. Infants \& Young Children. 19(2):109-122.

Frances A. (2016). Entrenched reductionisms: The bête noire of psychiatry. History

Psychology, 19(1), $57-59$.
Fiks AG, Ross ME, Mayne SL, Song L, Liu W, Steffes J, et al. (2016). Preschool ADHD diagnosis and stimulant use before and after the 2011 AAP practice guidenline. Pediatrics. December; 138(6), pii: e20162025 Epub 2016 Nov 15

Klochko V.E. (2013). Problema soznaniya v psikhologii: postneklassicheskiy rakurs / V.E. Klochko // Vestnik Moskovskogo universiteta. Ser.14. Psikhologiya. - №12, 3-20. [in Russian]

Kuznetsova L. E.. Gladko V. V. (2016). Psikhologicheskiye osobennosti detey $\mathrm{s}$ sindromom defitsita vnimaniya i giperaktivnosti. usloviya ikh psikhokorrektsii // Molodoy uchenyy. — №7, 327-331. [in Russian]

Landau S., Milich R. (1988). Social communication patterns of attentiondeficit-disordered boys. J. Abnorm. Child Psychol. 16 69-81. 10.1007/BF00910501

Landau S, Milich R, Diener M. (1998). Peer relations of children with attention-deficit hyperactivity disorder. Reading and Writing Quarterly: Overcoming Learning Difficulties. 14 (1):83-105.

Lahey BB, Lee SS, Sibley MH, Applegate B, Molina BS, Pelham WE. (2016). Predictors of adolescent outcomes among 4-6-year-old children with attention-deficit/hyperactivity disorder. J.

Abnorm

Psychol.125:168

Doi:10.1037/abn0000086.

Leopold DR, Christopher ME, Burns GL, Becker SP, Olson RK, Willcutt EG. (2016). Attentiondeficit/hyperactivity disorder and sluggish cognitive tempo throughout 
childhood: temporal invariance and stability from preschool through ninth grade. J Child Psychol Psych. 57:1066-74.

Doi: $10.1111 /$ jcpp. 12505 .

Nilsen E. S., Varghese A., Fecica A., Xu Z. (2015). Children's production of referential statements. An examination of the role of ADHD traits and executive functioning. J. Cogn. Dev. 36 68-82. 10.1017/S0305000911000432

Rowland AS, Lesesne CA, Abramowitz AJ. (2002). The epidemiology of attention-deficit/hyperactivity disorder (ADHD): A public health view. Mental Retardation and Developmental Disabilities Research Reviews. 8:162-170.

Rumyantseva M. V. (2003). Giperaktivnost $\mathrm{s}$ defitsitom vnimaniya: faktory riska. vozrastnaya dinamika. osobennosti diagnostiki // Defektologiya. - № 6, 22-28. [in Russian]

Sabbah W, Watt RG, Sheiham A, Tsakos G. (2008) Effects of allostatic load on the social gradient in ischaemic heart disease and periodontal disease: evidence from the Third National Health and Nutrition
Examination Survey. J Epidemiol Community Health 62, 415-20.

Semago M.M.. Semago N.Ya. (2011). Tipologiya otklonyayushchegosya razvitiya: Model analiza i eye ispolzovaniye $\mathrm{V}$ prakticheskoy deyatelnosti / Pod obshch. Red. M.M. Semago. - M.: Genzis. - 400 s. («Uchebnik XXI veka»). - ICBN 978-5-98563-242-2 [in Russian]

Semenovich A.S.

(2002).

Neyropsikhologicheskaya

diagnostika i korrektsiya $\mathrm{v}$ detskom vozraste. M.. 232 s. [in Russian]

Sirotyuk A.L. (2002).

Neyropsikhologicheskoye psikhofiziologicheskoye soprovozhdeniye obucheniya. M.. 288 s. [in Russian]

Vyigotskiy L. S. (2012). Psihologiya razvitiya cheloveka. - M.: Izd-vo Smyisl; Izd-vo Eksmo. - 1136 s., il. - (Biblioteka vsemirnoy psihologi) [in Russian]

Zinchenko Yu.P.

(2012).

Ponstneklassicheskaya

metodologiya $\mathrm{v}$ klinicheskoy psikhologii: nauchnaya shkola L.S. Vygotskogo - A.R. Luriya. Yu.P. Zinchenko. E.I. Pervichko // Natsionalnyy psikhologicheskiy zhurnal. - №8, 32-45. [in Russian] 
"SOCIALIZATION \& HUMAN DEVELOPMENT" INTERNATIONAL JOURNAL

\title{
PSYCHOLOGICAL FEATURES OF DIFFERENT ETHNIC GROUPS' MALE REPRESENTATIVES WITH DIFFERENT CULTURAL MODES
}

https://doi.org/00.00000/SHDISJ-00-0.0-0000

\section{Mambetova Arzy \\ ORCID 0000-0001-8586-5078}

\begin{abstract}
The article analyzes the works of domestic and foreign authors on the problem of family values in adolescence and describes the attempt to make a research on psychological features of different ethnic groups' representatives with different cultural modes. It contains theoretical and empirical analysis of psychological features of different ethnic groups' representatives with different social modes on the example of representatives of Ukrainian and Crimean Tatar ethnic groups. The problem of social psychological research of processes of development of integrity of personality is examined in the conditions of modern society. On the basis of assumption about the presence of types of socialization corresponding to the different cultural modes there are described the types of integrity of personality - traditional, modern, postmodern. The creation of psychological portraits of representatives of individual ethnic groups with different social styles allowed to study the above issues in more detail, and the novelty of this study would be an impetus for further in-depth scientific elaboration of this topic. Life within a certain cultural mode in an ethnic group influences the psychological wellbeing of ethnic representatives. Thus, the purpose of the article was to portrait the psychological characteristics of the representatives of the studied ethnic groups. The portraits were composed on the basis of socio-cultural components of psychological wellbeing. The aforementioned study was conducted among 70 young men aged from 18 to 25 years who belonged to Ukrainian and Crimean Tatar ethnic groups (35 people from each group respectively). The study used the next mentioned instruments: Questionnaire "Development of the whole personality in the conditions of modern changes" (Vlasova O.I., Shcherbina V.S.); Riff Psychological Well-Being Scale Technique. The results obtained allowed us to establish a typical distribution of the prevalence of known cultural modes among young men - Ukrainians and Crimean Tatars.
\end{abstract}

Key words: family, family values, personality, family style, different cultural modes, traditionalism, modernism, postmodernism.

\section{Introduction}

Our society is very dynamic, and every day there are some transformations of living conditions, which leads to changes in the value sphere. These changes are reflected in the outlook and features of the organization of life of the population. The development of modern youth is taking place in a multicultural world where people have features of different social systems. In such circumstances, it is very important to study and analyze the values of modern youth (Vakulenko, 2016; Vlasova, 2019; Onyshchenko, 2019).

Today, personality development takes place in a multifaceted society that has a dynamic and complex structure. If previously traditional, industrial (modern) 
and communicative (postmodern) cultural structures coexisted hierarchically, they form a single socialization environment, where there is no uniform interpretation of the norms, values and procedures of legitimation at the institutional level. Under these conditions, mutual understanding between people is achieved at the level of interpersonal communication (Vlasova, Fadieieva, \& Hulenko, 2014; Ananova, Vlasova, Danyliuk, et.al., 2015).

Therefore, we will analyze in more detail the most important thematic achievements of modern domestic and foreign scientists. Researches on the subject of formation of a holistic personality were carried out in different subject areas: (philosophy, psychology, pedagogy, sociology, etc.). In classical psychology, the integrity of the individual is regarded as the umwa and the mechanism of ensuring the psychological, social, and personal maturity of a person (Allport, 1955). This is manifested in the personality's ability to construct identities, self-actualization, and self-realization in academic achievement (Maslow, 1954; Erikson, 1968). Modern developments in positive psychology (Deci, \& Ryan, 2000) trace the tendency to search for the prospect of solving the scientific-methodical problem related to the search for criteria of personality integrity, the potential of the construct of subjective well-being or human happiness. The experience of happiness points to the harmony and unity and coherence of her inner world and living conditions. At the level of human subjective representation, this corresponds to the notion of the integrity of the individual as a system of human being to society.

Modern Ukrainian psychological science has also joined the consideration of this issue. O.I. Vlasova, I.V. Danylyuk, I.V. Ananova, A.S. Hulenko, K.M. Fadieieva, V.L. Shcherbyna and others dedicated their researches to the problem (Ananova, Vlasova, Hulenko, Danyliuk, Fadieieva, Shcherbyna, 2015).

Thus the purpose of the article was to explore the processes of development of integrity of personality is examined in the conditions of modern society and to portrait the psychological characteristics of the representatives of the studied ethnic groups.

\section{Theoretical background}

Psychological well-being as a holistic subjective experience is of great importance to the individual as it is linked to basic human values and needs, as well as to everyday concepts such as happiness, happy life, life satisfaction and self. In this situation, the person places emphasis on the subjective emotional evaluation of the person himself and his own life, as well as aspects of self-actualization and personal growth. Most successfully, these two aspects are synthesized and characterized in the six-component theory of psychological well-being by K. Ryff (Ryff, \& Keyes, 1995; Ryff, \& Singer, 1998).

Particular attention is paid to the selfdetermination theory of R. Ryan and E. Deci (Deci, \& Ryan, 2000) in terms of factors that influence psychological wellbeing. The authors believe that personal well-being is also related to basic psychological needs, namely: the need for autonomy, competence and a positive relationship with others. Autonomy refers to the perception of one's behavior as congruent with intrinsic values and desires of the individual. Autonomy is based on support and lack of control by other people. Competence is the tendency to master your environment and to be effective in it. Under 
"SOCIALIZATION \& HUMAN DEVELOPMENT" INTERNATIONAL JOURNAL

the "need to connect with others" is the desire to be close to other people. It develops if a person receives warmth and care from others. Thus, meeting psychological needs that are directly related to the social context increases the level of psychological well-being, otherwise the level of psychological wellbeing decreases (Ryff, \& Singer, 1998; Vlasova, Fadieieva, \& Hulenko, 2014).

Ethnicity and identity play an important role in the manifestation of psychological well-being. It is ethnicity that is associated with the inner world of man. Any other personality trait associated with its identification is usually functional in the social sense and is more likely to change.

Ethnic identity is based on a common cultural knowledge, cultural experience that is common to the group; then, of course, an ethnic group has the right to expect from each person behavior that is adequate for his or her role as a member of that group. And in this case, merely attributing such a role to the individual seems clearly insufficient. But it should also be borne in mind that the cultural foundations (cultural knowledge) on which intra-ethnic relations are based are much more complex and less structured than those on which interethnic relations are built (Danyliuk, Kozytska, \& Shykovets, 2018).

Specification of ethnic identity is largely determined not only by its subjective but also by social modality. Thus, under the conditions of the multiethnic structure of a society, the distribution of ethnic groups by their status is not excluded, which in turn makes it possible to display presentational identification (in order to achieve higher status) with a more prestigious ethnic community (while maintaining devotion to one's own ethnic values). This development can be triggered not only by the atmosphere of the micro environment, but also by the state as a whole (Bulatevich, \& Mambetova, 2018).

Moreover, representatives of small ethnic groups are generally characterized by an exacerbation of ethnic consciousness, which under certain conditions is capable of intensification. Hence the growing demands for commitment to shared group values and the strengthening of opposition to one's own communities.

In the context of social change, there is an influence of cultural modes on the peculiarities of the existence of the society (multicultural environment) of the country as a whole and its constituents (ethnic communities) in particular.

Based on this, we should elaborate on the notion of cultural style. It characterizes the historically steady, typical features of the order of constructing and substantive content of normative-value constructs that are inherent in social groups and individuals and are expressed in the material, ideal organizational and symbolic components of their individual and group life in the context of a particular society. Cultural mode is a specific historical phenomenon, inherent in the human community and is characterized by the principles of construction, ways of exchanging activities, material (technological) basis, the type of values and norms, socio-historical and spatio-temporal determination. The monomodal and multimodal societies are distinguished. Ukraine belongs to the latter. Depending on the methods of social production, cultural studies distinguish typical cultural modes, such as: archaic, traditional, modern and 
"SOCIALIZATION \& HUMAN DEVELOPMENT" INTERNATIONAL JOURNAL

postmodern (Vlasova, Fadieieva, \& Hulenko, 2014).

The culture in society is represented by a certain set of values and norms, historically formed by the practices of their realization. Therefore, the multidimensionality of socialization space can be explored through the multidimensionality of the cultural constructs or modes present in it. Cultural modes do not exist in themselves or affect some individuals, but on the contrary, the individual adapts them for himself, and carries out certain activities for them as conditions of his own being (Shcherbyna, 2014).

According to the traditional cultural mode values are considered independently of man and society, and given by an external authority (God, Nature), the imperative of life, which the individual may or may not respond in real life.

The modern cultural mode considers values as those created in the process of joint purposeful activity of people and having imperative, urgent value only in the context of achieving the common goal and efficiency of life of the group and the individual.

Postmodern cultural mode involves understanding of values as a kind of tools for game that is being undertaken in order to enjoy interaction in different areas of life. In this case, they are relative, contextual, state-oriented and communication processes.

\section{Methodology}

Ukraine is a multi-ethnic country. In the last six years, after the occupation of Crimea, more and more internally displaced persons have appeared in mainland Ukraine, namely the Crimean Tatars. The study of the socio-cultural context will make it possible to understand exactly what imprint it imposes on the psychological characteristics of representatives of different ethnicities. In the socio-cultural environment of different ethnic groups, the same social structures function, but their correlation in the environment of each ethnic group and their influence on the systems of ethnic factors and characteristics are unique. Thus, the creation of psychological portraits of representatives of individual ethnic groups with different social styles will allow to study the above issues in more detail, and the novelty of this study will be an impetus for further in-depth scientific elaboration of this topic.

Life within a certain cultural mode in an ethnic group influences the psychological well-being of ethnic representatives. Thus, the purpose of the article is to portrait the psychological characteristics of the representatives of the studied ethnic groups. The portraits should be composed on the basis of socio-cultural components of psychological well-being.

The aforementioned study was conducted among 70 young men aged from 18 to 25 years who belonged to Ukrainian and Crimean Tatar ethnic groups (35 people from each group respectively).

The study used the next mentioned instruments:

- Questionnaire "Development of the whole personality in the conditions of modern changes" (Vlasova O.I., Shcherbina V.S.) (Vlasova et. al., 2014; Shcherbyna, 2014).

The test measures existential fullness as it is subjectively felt by the subject. The Existence Scale consists of four subscales according to basic anthropological personality abilities that are necessary to 
"SOCIALIZATION \& HUMAN DEVELOPMENT" INTERNATIONAL JOURNAL

identify meaning: SD (self-distancing), ST (self-transcendence), F (freedom), V (responsibility). Here, self-transcendence and self-distancing constitute the personal factor or personal preconditions of being full, while freedom and responsibility are the existential factor or fullness due to the possibilities of the situation. The overall indicator for the test indicates the degree of completeness that is subjectively experienced by the person. The ratio of these scales determines belonging to one of three cultural modes: traditional, modern or postmodern. Defining this affiliation is one of the key objectives of our study and the reason for using this method.

- Ryff Psychological WellBeing Scale Technique (Ryff, \& Keyes, 1995).

The psychological well-being scale technique by $\mathrm{K}$. Ryff consists of the following scales: positive relationships with others, autonomy, environmental management, personal growth, life goals and self-acceptance. The scale of positive relationships with others characterizes the personality's ability to create and maintain trusting and open relationships with people. The autonomy scale characterizes the individual as independent and independent, capable of making decisions independently. The environment management scale describes a person's ability to influence the environment and control his or her own life. The scale of personal growth characterizes the individual as having a sense of constant self-development, realization of one's own potential. The Life Purpose Scale characterizes a person who has life goals and a meaningful existence. The selfacceptance scale characterizes the individual as accepting of himself, knows his strengths and weaknesses, and is positive about himself.

The results obtained allowed us to establish a typical distribution of the prevalence of known cultural modes among young men - Ukrainians and Crimean Tatars.

\section{Results}

Thus, traditional (50\%) and postmodern $(40 \%)$ cultural modes are dominant among Ukrainian young men (see Fig. 1). In theory, such a combination can create internal conflict in the society, since traditional and postmodern modes are fundamentally contradictory in the interpretation of values. Accordingly, the individual, adapting them for himself as a condition of his own being, is forced to carry out simultaneously two activities that contradict each other or are being directed against each other. We were able to verify this assumption later, after analyzing the psychological characteristics of the Ukrainian youths' social behaviors. 


\section{Distribution of cultural modes among Ukrainian young men}

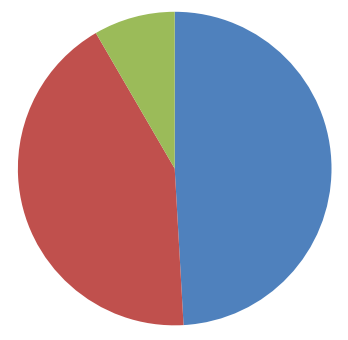

Traditional 50\%

Postmodern $40 \%$

Modern $10 \%$

Fig. 1 Distribution of cultural modes among Ukrainian young men

At the same time, the modern mode common points of contact with the $(60 \%)$ is dominant among Crimean Tatar approaches of traditional and postmodern youung men, The modern mode is in modes. This fact creates a favorable harmony with the traditional $(25 \%)$ and environment for cultural public dialogue. postmodern (15\%) modes (see Fig. 2). We were able to verify this assumption Theoretically, such a combination can later, after analyzing the psychological create a rather favorable situation in characteristics of the Ukrainian youths' society, because the approach to the values, social behaviors. promoted by the modern way, finds

\section{Distribution of cultural modes among Crimean Tatar young men}

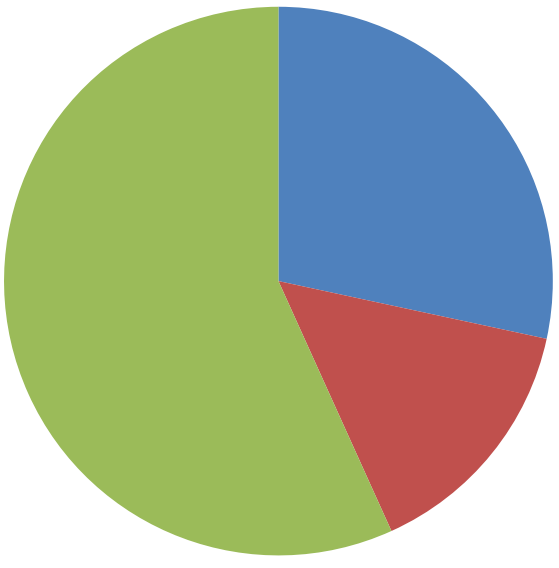

- Traditional 25\%

- Postmodern 15\%

Modern 60\%

Fig. 2 Distribution of cultural modes among Crimean Tatar young men.

We were also able to determine how the factors of psychological well-being (using the Riff Psychological Well-Being Scale) are reflected in the outlook of the studied youths - Ukrainians and Crimean Tatars, and how they exert their influence.
Thus, the Ukrainian young men are characterized by: average level of positive relations with others, maximum high level of autonomy, rather low level of environmental management, medium level of personal growth, low level of goals in 
"SOCIALIZATION \& HUMAN DEVELOPMENT" INTERNATIONAL JOURNAL

life (according to respondents, this is life in the country), medium level of selfinfluenced by social and political factors of acceptance (see Fig. 3).

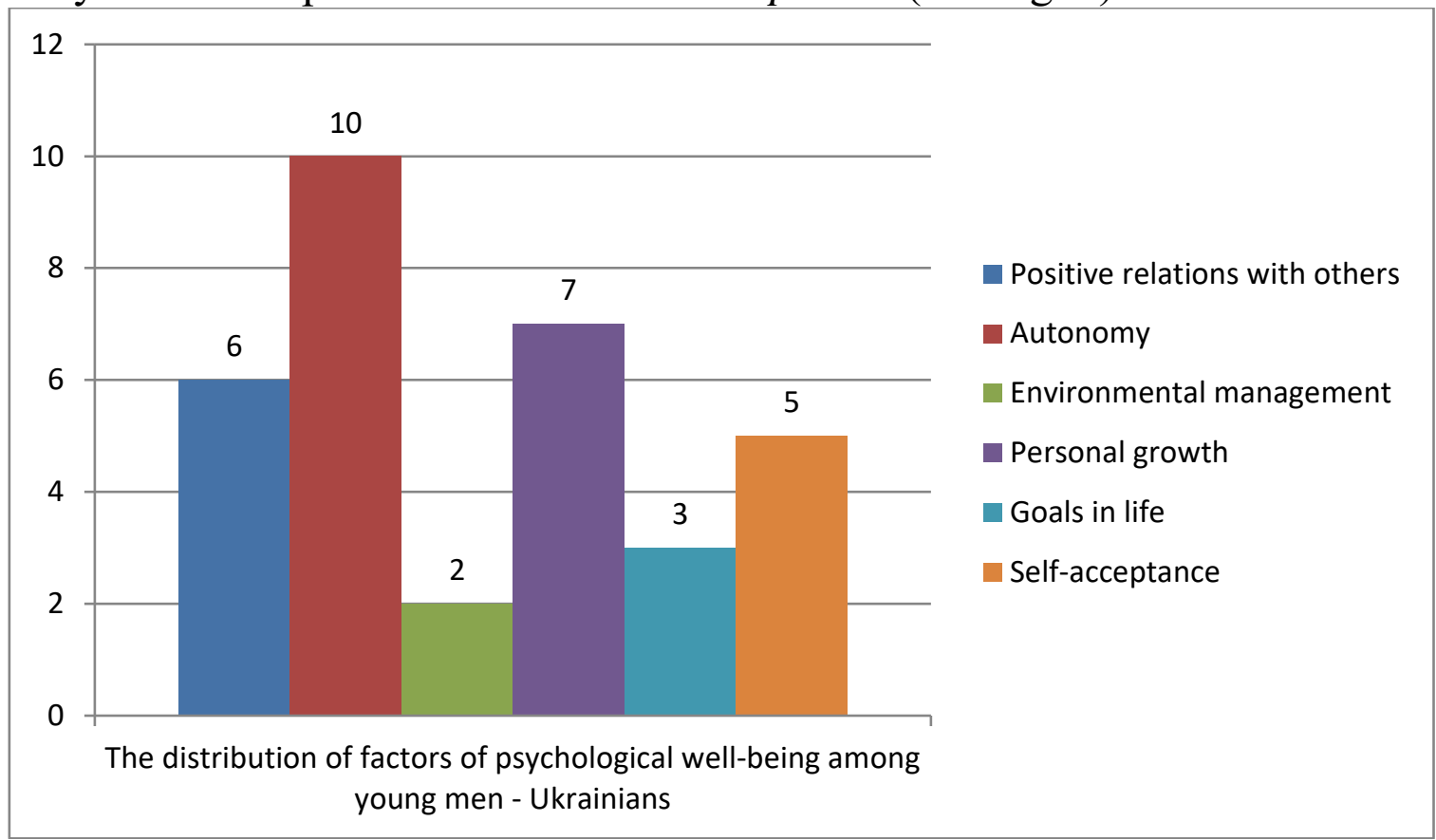

Fig. 3. The distribution of factors of psychological well-being among young men - Ukrainians.

The Crimean Tatar young men are personal growth, and a low level of goals characterized by a rather high level of in life (according to respondents, this is positive relations with others, an average influenced by social and political factors in level of autonomy, a maximum level of the country), medium level of selfenvironmental management, a high level of acceptance (see Fig. 4).

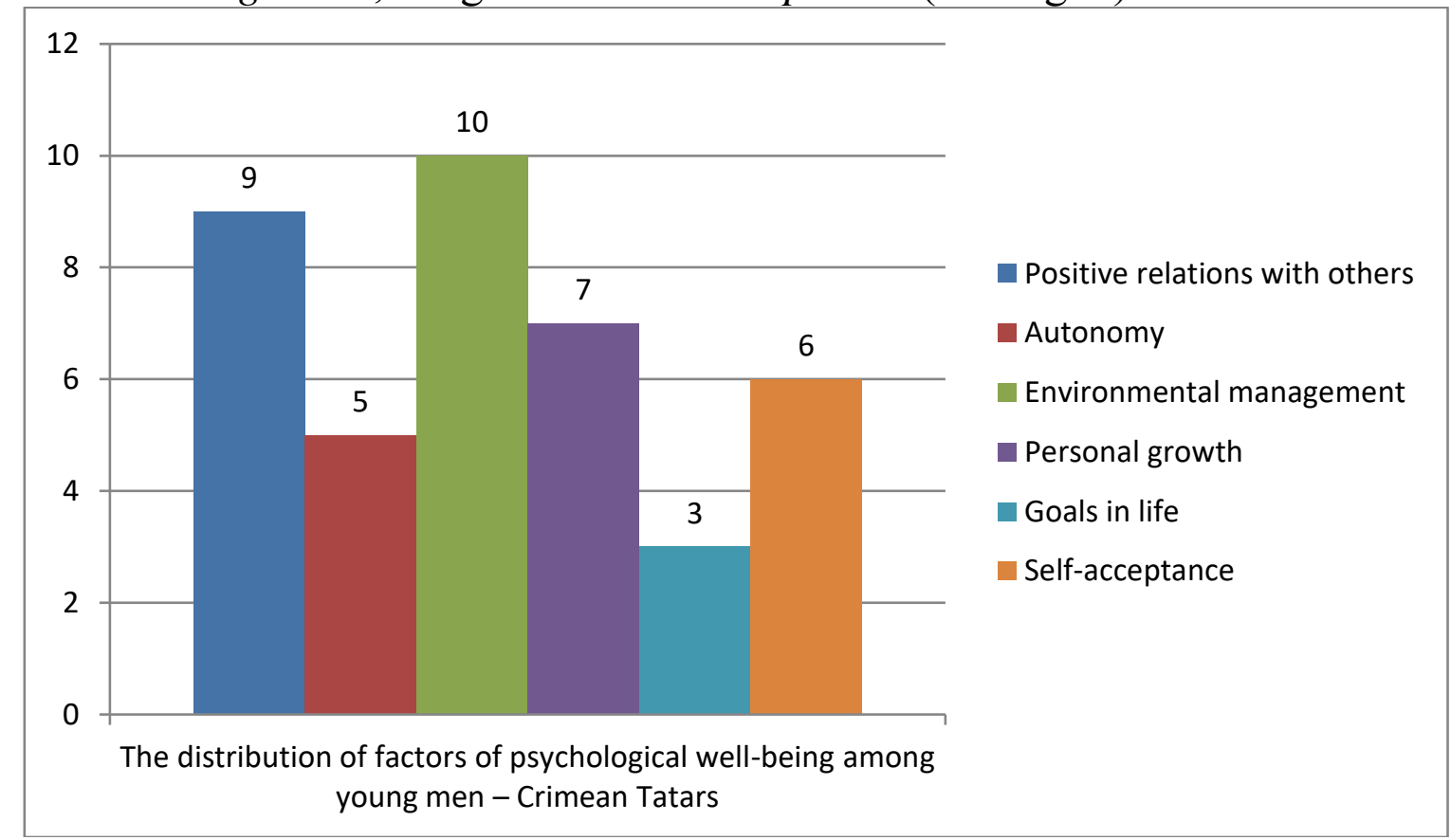

Fig. 4. The distribution of factors of psychological well-being among young men - Crimean Tatars In order to analyze the psychological conducted a correlation study of the peculiarities of Ukrainian and Crimean connection between cultural styles (the Tatar young men social behaviors, we questionnaire "Development of a holistic 
"SOCIALIZATION \& HUMAN DEVELOPMENT" INTERNATIONAL JOURNAL

personality in the context of modern changes" (Vlasova O. I., Shcherbina V. S.)) with psychological factors well-being (the Ryff Psychological Well-Being Scale technique).

Thus, we obtained a portrait of the psychological characteristics of the studied Ukrainian young men, who chose the dominant cultural modes in the Ukrainian community (see Table 1). This analysis has allowed us to develop a working out of assumptions about the personal psychological characteristics of persons belonging to certain cultural modes.

Consequently, young men Ukrainians who chose the traditional cultural mode have an average level of positive relations with others (the average correlation strength) (the result corresponds to the distribution of factors of psychological well-being among Ukrainian young men (Fig. 3)); a low level of autonomy (inverse correlation) (the result does not correspond to the distribution of factors of psychological well-being among Ukrainian young men (Fig. 3), where the level of autonomy was as high as possible hence the choice of values of the traditional way of young men - Ukrainians causes conflict with their autonomy); a low level of environmental management (inverse correlation) (the result corresponds to the distribution of factors of psychological well-being among young men - Ukrainians (Fig. 3)); a low level of personal growth (inverse correlation) (the result does not correspond to the distribution of factors of psychological well-being among young men - Ukrainians (Fig. 3), where the level of personal growth was average); an average level of goals in life (average strength of correlation) (the result does not correspond to the distribution of factors of psychological well-being among young men - in disputed one (Fig. 3), where the goal in life was average); an average level of self-acceptance (average correlation power) (the result corresponds to the distribution factors psyhological wellbeing among Ukrainian young men (Fig. 3)).

Young men - Ukrainians who chose a postmodern cultural mode, are characterized by an average level of positive relations with others (average correlation strength) (the result corresponds to the distribution of factors of psychological well-being among young men - Ukrainians (Fig. 3)); a high level of autonomy (strong correlation) (the result corresponds to the distribution of factors of psychological well-being among Ukrainian youths (Fig. 3); a low level of environmental management (inverse correlation) (the result corresponds to the distribution of factors of psychological well-being among Ukrainian youths (Fig. 3)); an average level of personal growth (average strength of correlation) (the result corresponds to the distribution of factors of psychological well-being among young men - Ukrainians (Fig. 3)); an average level of goalse in life (average strength of correlation) (the result does not correspond to the distribution of factors of psychological well-being among Ukrainian youth (Fig. 3), where the goal level in life was low); a high level of self-acceptance (strong correlation) (the result does not correspond to the distribution of factors of psychological well-being among young men - Ukrainians (Fig. 3), where the level of self-acceptance was average). 
"SOCIALIZATION \& HUMAN DEVELOPMENT" INTERNATIONAL JOURNAL

Table 1

Correlation of cultural modes (questionnaire "Development of holistic personality in the conditions of modern changes" (Vlasova O.I., Shcherbina V.S.)) with factors of psychological well-being (the method "Ryff psychological well-being scale ") for young men - Ukrainians

\begin{tabular}{|c|c|c|c|}
\hline Cultural modes & Psychological well-being factors (Riff) & Correlation coefficient & p-value \\
\hline \multirow{6}{*}{ Traditional } & Positive relations with others & 0,68 & 0,001 \\
\hline & Autonomy & $-0,9$ & 0,001 \\
\hline & Environmental management & $-0,9$ & 0,001 \\
\hline & Personal growth & $-0,9$ & 0,001 \\
\hline & Goals in life & 0,7 & 0,001 \\
\hline & Self-acceptance & 0,6 & 0,001 \\
\hline \multirow[t]{6}{*}{ Postmodernism } & Positive relations with others & 0,6 & 0,001 \\
\hline & Autonomy & 0,9 & 0,001 \\
\hline & Environmental management & $-0,9$ & 0,001 \\
\hline & Personal growth & 0,6 & 0,001 \\
\hline & Goals in life & 0,6 & 0,001 \\
\hline & Self-acceptance & 0,9 & 0,001 \\
\hline
\end{tabular}

We also described a portrait of the psychological traits of the investigated Crimean Tatar young men who chose the dominant cultural modes in the Crimean Tatar community (see Table 2). This analysis has allowed us to develop a working out of assumptions about the personal psychological characteristics of persons belonging to certain cultural modes.

Thus, Crimean Tatar young men who have chosen a modern cultural style have a high level of positive relations with others (strong correlation) (the result corresponds to the distribution of factors of psychological well-being among Crimean youths (Fig. 4)); an average level of autonomy (average strength of correlation) (the result corresponds to the distribution of factors of psychological well-being among the young men - Crimean Tatars (Fig. 4)); a low level of environmental management (inverse correlation) (the result does not correspond to the distribution of factors of psychological well-being among the youth - Crimean Tatars (Fig. 4), where the level of environmental management was high); an average level of personal growth (average strength of correlation) (the result corresponds to the distribution of factors of psychological well-being among the youth - Crimean Tatars (Fig. 4)); a high level of goals in life (strong correlation) (the result does not correspond to the distribution of factors of psychological well-being among the youth - Crimean Tatars (Fig. 4), where the level of purpose in life was average); a low level of self-acceptance (inverse 
"SOCIALIZATION \& HUMAN DEVELOPMENT" INTERNATIONAL JOURNAL

correlation) (the result does not correspond to the distribution of factors of psychological well-being among the young men - Crimean Tatars (Fig. 4), where the level of self-acceptance was average).

Table 2

Correlation of cultural modes (questionnaire "Development of holistic personality in the conditions of modern changes" (Vlasova O.I., Shcherbina V.S.)) with factors of psychological well-being (the method "Ryff psychological well-being scale") for young men - Crimean Tatars

Cultural modes $\quad$ Psychological well-being factors (Ryff) Correlation coefficient p-value

\begin{tabular}{|l|l|r|r|}
\hline \multirow{3}{*}{ Modernism } & Positive relations with others & 0,9 & 0,001 \\
\cline { 2 - 4 } & Autonomy & 0,7 & 0,001 \\
\cline { 2 - 4 } & Environmental management & 0,9 & 0,001 \\
\cline { 2 - 4 } & Personal growth & 0,6 & 0,001 \\
& Goals in life & 0,9 & 0,001 \\
\hline & Self-acceptance & $-0,9$ & 0,001 \\
\hline
\end{tabular}

The results obtained show that the peculiarities of the psychological wellbeing factors inherent in cultural modes do not always correspond to the peculiarities of the psychological well-being factors inherent in individuals or groups. In view of this, it is important to further explore the interplay of values between ethnic groups and cultural modes. The obvious fact is that an individual can change their own value code by accepting the value code of a particular cultural mode. The same processes can be a characteristic of ethnic groups. A detailed study of these and the possibility of further adjustment through educational and development strategies is the goal of our further research.

\section{Discussion}

The process of conducting our research was divided into two directions:

1. Conducting an empirical study on the prevalence of cultural modes among young male members of the Ukrainian and Crimean Tatar ethnic groups.
2. Conducting an empirical study on the correlation of cultural modes with factors of psychological well-being for young men - Ukrainians and Crimean Tatars.

In this cross-cultural approach, in our opinion, the uniqueness of this study is in comparison with the experience of other researchers already existing (Shcherbyna, 2014; Causadias, Vitriol, \& Atkin, 2018; Baban, 2018; Yang, Liang, Quan, Jiang, $\mathrm{Yu}$, \& Zheng, 2019).

The study was conducted in several stages. At the organizational stage, theoretical information concerning the issue of cultural styles and well-being factors for different ethnic groups was elaborated. In the second stage, empirical research was conducted using standardized techniques. The next stage was the processing and interpretation of the results.

In addition, there are limitations to the results obtained. Thus, the study hypothesis was tested only on young male representatives of Ukrainian and Crimean 
"SOCIALIZATION \& HUMAN DEVELOPMENT" INTERNATIONAL JOURNAL

Tatar ethnic groups. However, it is also promising to study the situation in ethnic groups in general. This study opens up the potential for further scientific research and highlights the relevance of the chosen direction of scientific research.

\section{Conclusion}

Theoretical facts indicate that the socio-cultural context (cultural attitudes and belonging to ethnic communities) influences the representatives of the contemporary cultural environment, which is reflected in certain features of the psychological portrait of the individual. In order to study the peculiarities of these phenomena empirically, the authors investigated the psychological peculiarities of social ways in the representatives of the Ukrainian and Crimean Tatar ethnic groups in the contemporary multicultural environment of Ukraine.

The results obtained prove the need for further research in the chosen field.

We have found the expediency of finding strong positive factors that can be used to create tools for positively influencing young people in order to set them up for successful activities, to preserve their own ethno-cultural values in the conditions of adaptation to the challenges of modern society.

This issue is currently relevant because ethnocultural values are the important set of concepts, attitudes, feelings and thinking that give a person an intuitive or conscious incentive to act in order to achieve, preserve or restore the benefits and patterns of interaction envisaged by these values. cultural identity code.

This will greatly increase the efficiency of professional activity and will guarantee the development of a positive identity and the establishment of positive social interaction and re-socialization.

Acknowledgments. The study did not receive a grant from any financial agency in state, commercials or the nonprofit sector.

\section{References}

Allport G.W. (1955). Becoming: Basic Considerations for a Psychology of Personality. New Haven: Yale University Press.

Ananova I. V., Vlasova O. I., Hulenko A. S., Danyliuk I. V., Fadieieva K. - M., Shcherbyna V. L. (2015) The types of personal integrity of the modern Ukrainian multicultural society Socio-economic sciences and challenges of modern technology and planetary communication: International Conference on ICT Management for Global Competitiveness and Economic Growth in Emerging Economies ICTM 2015 : http://papers.ssrn.com Retrieved from URL: http://papers.ssrn.com/sol3/cf dev/ AbsByAuth.cfm?per_id=2469326 [in Ukraine].

Banban D. (2018). Harmony in diversity: an empirical study of harmonious co-existence in the multi-ethnic culture of Qinghai. International Journal of Anthropology and Ethnology (2018) 2:1. https://doi.org/10.1186/s41257-0180010-6

Bulatevich N., Mambetova A. (2018). Psychological peculiarities of parenthood apprehensions of Ukrainians and Crimean Tartars. International Journal of Education \& Development, 1, $13-24$.

Causadias, J. M., Vitriol, J. A., \& Atkin, A. L. (2018). Do we overemphasize the 
"SOCIALIZATION \& HUMAN DEVELOPMENT" INTERNATIONAL JOURNAL

role of culture in the behavior of racial/ethnic minorities? Evidence of a cultural (mis)attribution bias in American psychology. American Psychologist, 73(3), 243255. https://doi.org/10.1037/amp000 0099

Danyliuk I.V., Kozytska I.V. \& Shykovets S.O. (2018). The cultural syndrome "Individualism - collectivism" and its psychological peculiarities including well-being of regional communities' representatives in Ukraine. Scientific journal "Fundamental and applied research in practice of leading scientific schools", 30, 6, $55-61$.

Deci E., \& Ryan R. (2000). Selfdetenrrination theory and the facilitation of intrinsic motivation, social development, and well-being. American Psychology. Vol. 55 (1). P. 68-78.

Erikson E. (1968). Identity: Youth and Crisis. New York: Norton.

Maslow A. (1954). Motivation and Personality. NY: Harper.

Onyshchenko V. (2019). Rozvytok tsilovoi spriamovanosti osobystosti pidlitkiv - turystiv [Development of targeting personality of teenagers - tourists]. Visnyk Kyivskoho Natsionalnoho Universytetu imeni Tarasa Shevchenka. Psykholohiia. Issue 1. Vol. 10.

Ryff, C.D., \& Keyes, C.L.M. The structure of psychological well-being revisited // Journal of Personality and Social Psychology, 1995, 69, 719-727

Ryff, C.D., \& Singer, B. Human health: new directions for the next millennium // Psychological Inquiry, 1998, 9, 69-85.
Shcherbyna V. L. (2014) Tsilisnist osobystosti V umovakh bahatoukladnoho suspilstva [The integrity of the individual in a mixed society] «Aktualni problemy sotsiolohii, psykholohii, pedahohiky» Zbirnyk naukovykh prats. - K.: Lohos - "Actual problems of sociology, psychology, pedagogy" Collected Works. - Ed.1 (22) $K$.. Logos, 1 (22), 165-172 [in Ukraine].

Shykovets S.O., Mambetova A.A. (2018). Psychological features of the representatives' identity in the regional communitiesof Ukraine and Poland. Naukovyi Visnyk Khersonskoho Derzhavnoho Universytetu. Psykholohiia Scientific Bulletin of Kherson State University. Psychology, 3, 1, 142 148.

Vakulenko O. (2016) Onovlennia identytetiv: uproblemnennia sotsialno-psykholohichnoho dyskursu [Upgrade of identificators: problematization of sociopsychological discourse]. Psykholohiia i suspilstvo., pp. $105-$ 114.

Vlasova O. I., Fadieieva K.-M. O., Hulenko A. S. (2014) Psykholohichnyi konstrukt tsilisnosti osobystosti $\mathrm{V}$ konteksti metodolohii filosofii ekzystentsializmu ta ekzystentsiinoi psykholohii [Construct psychological integrity of the individual in the context of the methodology of the philosophy of existentialism and existential psychology] fund-issledintern.esrae.ru Retrieved from URL: fund-issled-intern.esrae.ru/5-60 [in Ukraine]. 
"SOCIALIZATION \& HUMAN DEVELOPMENT" INTERNATIONAL JOURNAL

Vlasova O.I. (2019). Influence of internet dependency on young people selfactualization. Socialization \& Human Development: International Scientific Journal,1, 1, 5-12.

Yang Y., Liang F., Quan F., Jiang G., Yu K., \& Zheng Y. (2019). The
Importance of Ethnicity: Developing a Measure of Minority Ethnic Value and Value-Expressive Behavior Among Chinese Ethnic Minorities. Front. Psychol., 19. https://doi.org/10.3389/fpsyg.2019.0 $\underline{2603}$ 
"SOCIALIZATION \& HUMAN DEVELOPMENT" INTERNATIONAL JOURNAL

\section{FEATURES OF DEPRESSIVE DISORDER IN WOMAN \\ DURING PREGNANCY}

https://doi.org/10.37096/SHDISJ-19-1.1-0000

Molotokas Antonina

https://orcid.org/0000-0002-0061-1528

\section{Abstract}

Purpose of the article is to show features of depressive disorder during pregnancy and how it can be different according to various personal indicators.

Pregnancy and depression often go hand in hand. This condition affects about every tenth pregnant woman. According to recent research, sudden surges and changes in the hormonal background that accompany the entire pregnancy can really affect brain biochemistry, which in turn can lead to real clinical depression. The procedure of research registered at the women's consultation and obstetric ward and pathology department of pregnancy in Maternity hospital No. 3 (Kyiv). It lasted for 5 months. The group of pregnant women consisted of 100 people aged 18 to 42 years. Among them were 35 women in 1 trimester of pregnancy, 40 women in 2 trimester of pregnancy, 25 women in 3 trimester of pregnancy. To identify the presence and severity of depression among pregnant women, we used the following methods: Hamilton Depression Scale, Behterev Depression Questionnaire (female version).

Anxiety and depression in women during pregnancy require early detection and correction due to their significant negative impact on pregnancy, childbirth, postpartum and further psychophysical development and social adaptation of children. Different indicators of age and trimester affect the level of expression of the depressive disorder.

If woman had problems with conception or she was treated for infertility, the probability of her depression in her pregnancy increases by 10 times. Depression may be more likely to eclipse pregnancy and women who have suffered mental illness, anxiety, or depression before conception. This disorder may also occur in problematic relationships, as well as in situations where relatives have had a depression or mental illness, a woman has already had a miscarriage or her current pregnancy is a high-risk group. Depression during pregnancy has significant implications for pregnancy outcomes and maternal and child health. There is a need to identify which family, physical and mental health factors are associated with depression during pregnancy.

Key words: pregnancy, anxiety, depression, depressive disorder, research, postpartum period.

\section{Introduction}

The phenomenon of pregnancy is one of the most important factors in the formation of a specific complex of anatomical, neuro-psychological, psychological and social-psychological formations and changes of women, which are most often described in the literature by the term "maternal sphere of personality", "motherhood" (Filipp 2002). ). In this case, pregnancy in women and its phenomena are, firstly, a specific phase of gender and individual ontogeny, and secondly, a multilevel, multidimensional formation 
"SOCIALIZATION \& HUMAN DEVELOPMENT" INTERNATIONAL JOURNAL

that causes the above-mentioned specific changes in her gender status. (Filippova, 1996)

From the point of view of medical psychology, pregnancy as a specific variant of health ("third condition") (Pushkareva, 2005) is an element of the continuum "health-illness", inevitably reflected in the woman's consciousness (more precisely in the maternal sphere of woman's consciousness), and thus, reflecting in consciousness, should be combined with its internal picture - the internal (subjective) picture of pregnancy (IPP - the internal picture of pregnancy), as well as other clinical phenomena (health, illness, treatment, outcome of illness, etc.) are represented in the internal picture of disease and health (Nechaeva, 2005).

The developed classification of types of attitude to pregnancy is presented, based on the theory of relations of V.M. Myasishcheva.

Purpose of the article is to show features of depressive disorder during pregnancy and how it can be different according to various personal indicators.

\section{Theoretical background}

Depression and depressive disorders are more commonly considered in psychiatry, but lately, this disorder has been extensively studied in medical and clinical psychology, particularly in terms of the features of depressive disorders in pregnant women.

From early pregnancy to the postpartum period many important changes occur simultaneously at the biological, psychological and social levels. Adapting to these changes can put women at risk of psychological distress. The literature highlights a particularly difficult period of adaptation for first-time pregnant women (Figueiredo).
It is proved that for the development of the child the most dangerous are pathological reactions to stress and the appearance of affective pathology in the second and third trimesters of pregnancy. The effects of stress on pregnant women adversely affect the psychophysiological characteristics of infants at birth and are found to be similar to mothers addicted to smoking. Mechanisms of development of psychopathological symptomatology of non-psychotic level are conditioned by correlation of personality typology, degree of personal maturity, social and psychological factors, nature of social functioning (Pushkareva, 2017).

The most common emotional disorders encountered during gestation are anxiety and anxiety-depressive disorders. Anxiety noted by the most pregnant women is believed to be a major factor in allowing the line between women with normal physiological pregnancy and complicated pregnancy (Kolesnikov, 2012).

In this regard, obstetricians and gynecologists need effective data to help pregnant women with their current psychological status, which is largely determined by the state of the emotional sphere (Pushkareva, 2005).

The risk of developing psychosis of the gestational period in the general population is $0.1-0.25 \%$. At the same time, postpartum psychoses account for $45 \%$ $86 \%$ of all psychoses, for lactation (during the feeding period) - $10 \%-42 \%$ and psychoses of the pregnancy period - 3\% $15 \%$. It is considered that the level of severe mental disorders during pregnancy is the same or even lower compared to the level of soreness outside of childbirth. Postpartum psychoses occur at a frequency of 1-2 per 1000 births (Targum, 1979) 
"SOCIALIZATION \& HUMAN DEVELOPMENT" INTERNATIONAL JOURNAL

Psychoses of pregnancy are a combined nosological group. In this case, pregnancy itself is not a cause of psychosis, but can only provoke the onset or exacerbation of already existing mental disorders. Psychotic disorders can be facilitated by various somatic pathologies that develop during this period. Psychological difficulties (family disharmony, loneliness, death of loved person) are essential (Nechaeva, 2005).

An important role in the pathogenesis of psycho-emotional disorders in women during pregnancy is played by the premorbid level of functioning of the individual, which prevails during the period of onset of pregnancy - the level of maturity of gender-role identity, which the woman has acquired by this time. It has been proven that during pregnancy there are changes in the emotional sphere of women in the direction of increasing lability. Woman becomes more sensitive and more susceptible to mood swings.

During pregnancy the subcortical structures of the brain increase the phenomenon of excitation, and in its cortex - signs of induced inhibition. Mature personality functioning correlates with better adaptation to the condition pregnancy, a more flexible adaptation to hormonal (internal) and social (external) changes during pregnancy. (Evans, Heron, 2001)

A number of foreign studies have shown that anxiety and depression in women during pregnancy require early detection and correction due to their significant negative impact on pregnancy, childbirth, postpartum and further psychophysical development and social adaptation.

Anxiety and depressive disorders in women during pregnancy can be predictors of anxiety and depressive disorders for mother mother during the first year of child's life, which adversely affects the woman's adaptation to motherhood and causes early childhood developmental abnormalities (Pushkareva, 2005).

When depressive disorders occur during pregnancy, one-third of women have depression after delivery. (McNeil, Blennow, 1988). Pre-natal depression is regarded as the most significant risk factor for the development of postpartum depression, which has a known pathological effect on the functional state of the mother, the formation of maternalinfant relationships. Depressive disorders also adversely affect the social functioning of pregnant women (Beck, 1996).

In psychiatry the interconnections and mutual influences of functional features of the central nervous system, complications of pregnancy and psychological features of the pregnant woman have been studied. Depressive disorders in women have hardly been studied in pregnancy. Dysharmonic marital relations in the family of a pregnant woman are considered by foreign authors as a significant etiological factor in the development of depressive disorders. Even with a fairly harmonious relationship of the couple, the family, which is expecting the birth of the baby, is going through the verge of serious changes, its functioning becomes unstable. As you move to a new stage in the life cycle of a family, its structure changes, new functions appear, and this affects the mental state of a pregnant woman. In turn, changes occurring in her body and psyche, largely determine the psychological situation in the family, the nature of the relationships of its members (Eydemiller, Dobryakov, Nikolskaya, 2003).

Methodology 
"SOCIALIZATION \& HUMAN DEVELOPMENT" INTERNATIONAL JOURNAL

The study of the features of depressive disorders in pregnant women was conducted on the basis of the Department of Pathology and Women's Consultation of the Maternity Hospital No. 3 (Kyiv). The procedure of research registered at the women's consultation and obstetric ward and pathology department of pregnancy in Maternity hospital No. 3 (Kyiv). It lasted for 5 months.

To identify the presence and severity of depression among pregnant women, we used the following methods: Hamilton Depression Scale, Behterev Depression Questionnaire (female version).

The group of pregnant women surveyed consisted of 100 people aged 18 to 42 years. Among them were 35 women in 1 trimester of pregnancy, 40 women in 2 trimester of pregnancy, 25 women in 3 trimester of pregnancy.

Analyzing the anamnestic data, it was possible to identify the main negative events in patients' lives in the last few months. These include:

- conflicts with husband - 60\%;

- social and material problems $37 \%$;

- physiological changes - 26\%;

- conflicts with parents or colleagues $-23 \%$;

- death of a relative $-6 \%$;

- Other - 24\%.

\section{Results}

According to the Behterev Depression Questionnaire received the following data of depressive states in pregnant women (Fig. 1). In $40 \%$ of the surveyed pregnant women did not find depressive manifestations, which is an optimal indicator of their well-being and mood, and in $60 \%$ of women, certain characteristics of depressive states were established, which made it possible to diagnose the presence of depression. At the same time, the neurotic spectrum of depression was found in $26 \%$ of respondents who have a combination of depressed moods with anxiety for themselves and the child, are excessively emotional, pay attention to any unclear symptoms and information and therefore have an increased neurotic background.

Another $24 \%$ of pregnant women are characterized by the diagnostic uncertainty of depression, episodic manifestations of certain symptoms that may indicate a pregnant woman's predisposition to depressive experiences, but because of the lability of such conditions, the clinical form of depression cannot be unequivocally diagnosed. Provided timely provision of psychological care, such depressive symptoms will not remain. Only $10 \%$ of pregnant women surveyed have significant manifestations of depression (both physiologically and well-being). 


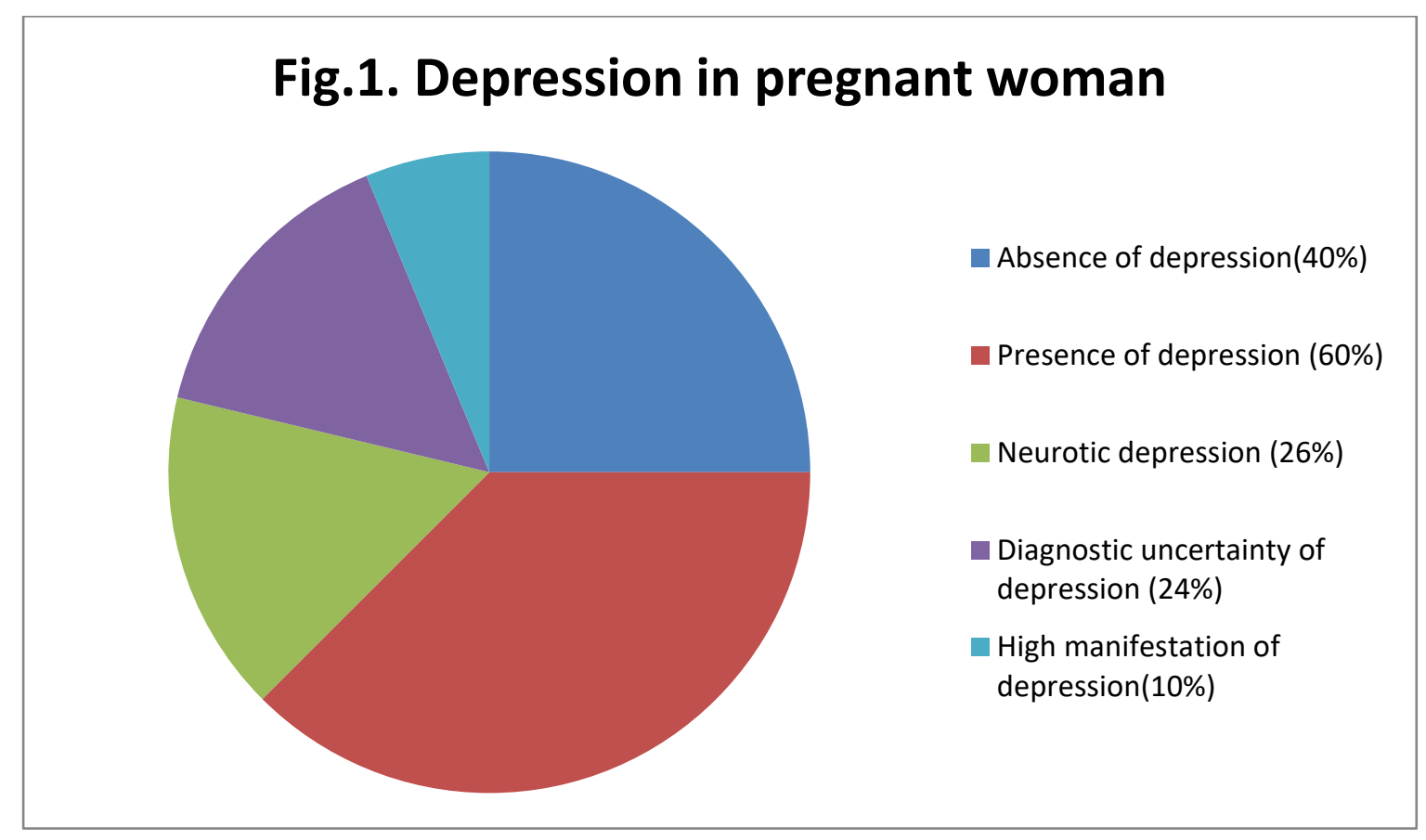

Analyzing the manifestations of that two pregnant women of the oldest depressive states in pregnant women of category (over 40 years of age) have a different ages, we found that they were neurotic spectrum of depression (40\%), absent in 9 young women under 20 years two have diagnostically undefined $(36 \%), 13$ women aged 30-39 years characteristics $(40 \%)$ and one pregnant $(37.1 \%)$ and in 18 pregnant women aged woman has a clearly significant 20-29 years (Table № 1). It should be noted manifestation of depression (20\%).

Table 1. Depression in pregnant woman of different ages

\begin{tabular}{|c|c|c|c|c|c|c|c|c|c|c|}
\hline \multirow[t]{2}{*}{ Depression } & \multicolumn{2}{|c|}{$\begin{array}{c}\text { Total } \\
(n=100)\end{array}$} & \multicolumn{2}{|c|}{$\begin{array}{l}\text { Age under } \\
20 \text { years } \\
(\mathbf{n}=\mathbf{2 5})\end{array}$} & \multicolumn{2}{|c|}{$\begin{array}{c}\text { Age } 20-29 \\
\text { years } \\
(n=35) \\
\end{array}$} & \multicolumn{2}{|c|}{$\begin{array}{ll}\text { Age } & 30-39 \\
\text { years } & \\
(n=35) & \\
\end{array}$} & \multicolumn{2}{|c|}{$\begin{array}{l}\text { Over } \quad 40 \\
\text { years } \\
(n=5)\end{array}$} \\
\hline & $\mathbf{n}$ & $\%$ & $\mathbf{n}$ & $\%$ & $\mathbf{n}$ & $\%$ & n & $\%$ & n & $\%$ \\
\hline Absence of depression & 40 & $40 \%$ & 9 & $36 \%$ & 18 & $51,4 \%$ & 13 & $37,1 \%$ & & \\
\hline Presence of depression & 60 & $60 \%$ & 16 & $64 \%$ & 17 & $48,6 \%$ & 22 & $62,9 \%$ & 5 & $100 \%$ \\
\hline Neurotic depression & 26 & $26 \%$ & 8 & $32 \%$ & 6 & $17,1 \%$ & 10 & $28,6 \%$ & 2 & $40 \%$ \\
\hline $\begin{array}{l}\text { Diagnostic uncertainty } \\
\text { of depression }\end{array}$ & 24 & $24 \%$ & 6 & $24 \%$ & 8 & $22,9 \%$ & 8 & $22,9 \%$ & 2 & $40 \%$ \\
\hline $\begin{array}{l}\text { High manifestation of } \\
\text { depression }\end{array}$ & 10 & $10 \%$ & 2 & $8 \%$ & 3 & $8,6 \%$ & 4 & $11,4 \%$ & 1 & $20 \%$ \\
\hline
\end{tabular}

The neurotic spectrum of depression was detected in 8 pregnant women under 20 $(32 \%)$, in 6 women aged 20-29 years $(17.1 \%)$, in 10 women aged $30-39$ years (28.6\%) and observed in 2 pregnant women over 40 years $(40 \%)$. Thus, the absence of depression $(36 \%)$ or its neurotic spectrum $(32 \%)$ is most characteristic for young pregnant women under 20 years, and the most seen characteristic for women aged 20-29 is the absence of depression (51.4\%) and its neurotic form. manifestation (32\%). Pregnant women aged 30-39 years do not have depression (37.1\%), but about a third of them have a neurotic spectrum and diagnostic uncertainty about depression 
"SOCIALIZATION \& HUMAN DEVELOPMENT" INTERNATIONAL JOURNAL

(28.6\% and $22.9 \%)$. Pregnant women over 40 are most prone to depression $-40 \%$ of those surveyed have a neurotic spectrum of depression and diagnostic uncertainty, and $20 \%$ of them have obvious manifestations of depression.

At different trimesters of pregnancy, women also have different manifestations and symptoms of depression - its absence is most characteristic of women in the second trimester of pregnancy, when the first experiences about the health of the child decreased, and before the birth is enough time not to think about them prematurely (Table №2):

Table № 2. Depression in pregnant woman at different trimesters

\begin{tabular}{|l|l|l|l|l|l|l|}
\hline \multirow{2}{*}{ Trimester of pregnancy } & \multicolumn{1}{|c|}{$\begin{array}{c}\text { I Trimester } \\
\text { Depression }\end{array}$} & \multicolumn{2}{c|}{$\begin{array}{c}\text { II Trimester } \\
(\mathbf{n = 4 0 )}\end{array}$} & \multicolumn{2}{c|}{$\begin{array}{c}\text { II Trimester } \\
\text { (n=25) }\end{array}$} \\
\cline { 2 - 7 } & $\mathbf{n}$ & $\mathbf{\%}$ & $\mathbf{n}$ & $\mathbf{\%}$ & $\mathbf{n}$ & $\mathbf{\%}$ \\
\hline Absence of depression & 14 & $40 \%$ & 20 & $50 \%$ & 6 & $24 \%$ \\
\hline Presence of depression & $\mathbf{2 1}$ & $\mathbf{6 0 \%}$ & $\mathbf{2 0}$ & $\mathbf{5 0 \%}$ & $\mathbf{1 9}$ & $\mathbf{7 6 \%}$ \\
\hline Neurotic depression & 9 & $25,7 \%$ & 8 & $20 \%$ & 9 & $36 \%$ \\
\hline $\begin{array}{c}\text { Diagnostic uncertainty of } \\
\text { depression }\end{array}$ & 10 & $28,6 \%$ & 8 & $20 \%$ & 6 & $24 \%$ \\
\hline $\begin{array}{l}\text { High manifestation of } \\
\text { depression }\end{array}$ & 2 & $5,7 \%$ & 4 & $10 \%$ & 4 & $16 \%$ \\
\hline
\end{tabular}

Absence of depression is characteristic of $40 \%$ of pregnant women in the 1 st trimester, half of pregnant women in the second trimester $(50 \%)$ and only $24 \%$ of women in the third trimester of pregnancy.

The neurotic spectrum of depression is found in third of pregnant women in the third trimester $(36 \%), 25.7 \%$ of women in the first trimester and $20 \%$ in the second trimester. We consider this situation quite obvious, because during the third trimester women are growing anxious and anxious about the last weeks of pregnancy, they are worried about childbirth, afraid of it, thinking about what kind of mother she will become, worried that she will not be able to understand the needs of their newborn children, etc. .

Diagnostic uncertainty of depression is found in a similar number of women in the 1st, 2 nd and 3rd trimesters of pregnancy (from $20 \%$ to 24\%). And high manifestation of depression is most seen in pregnant women in the third trimester
$(16 \%)$. In this case, the manifestations of depression are almost absent in women who are in the first trimester of pregnancy.

Therefore, women in the first trimester of pregnancy are most characterized by the absence of depression $(40 \%)$ and the diagnostic uncertainty of depression, episodic manifestations of individual symptoms (28.6\%). Half of pregnant women in the second trimester are characterized by the absence of depression, and another $20 \%$ of women have a neurotic spectrum of depressive experiences. In the third trimester, women have a clear predominance of neurotic depression (36\%), and it is in the third trimester that most women have a significant depression $(16 \%)$ associated with fear of giving birth, feelings about their baby's future.

To clarify the conclusions about the characteristic manifestations of depressive states among pregnant women, we used Hamilton's depression scale, which analyzed not only the degree of depression (from the norm (absence) to severe), but 
also some of the most expressive symptoms (Fig.№ 2, Table №2). In 58\% of pregnant women there was no depression, which indicates the norm of their psychoemotional well-being. In $24 \%$ of pregnant women have mild depressive disorder, episodic manifestations of minor symptoms of depression. Another $10 \%$ of pregnant women have moderate-grade depressive disorder, and $8 \%$ have severegrade depressive disorder.

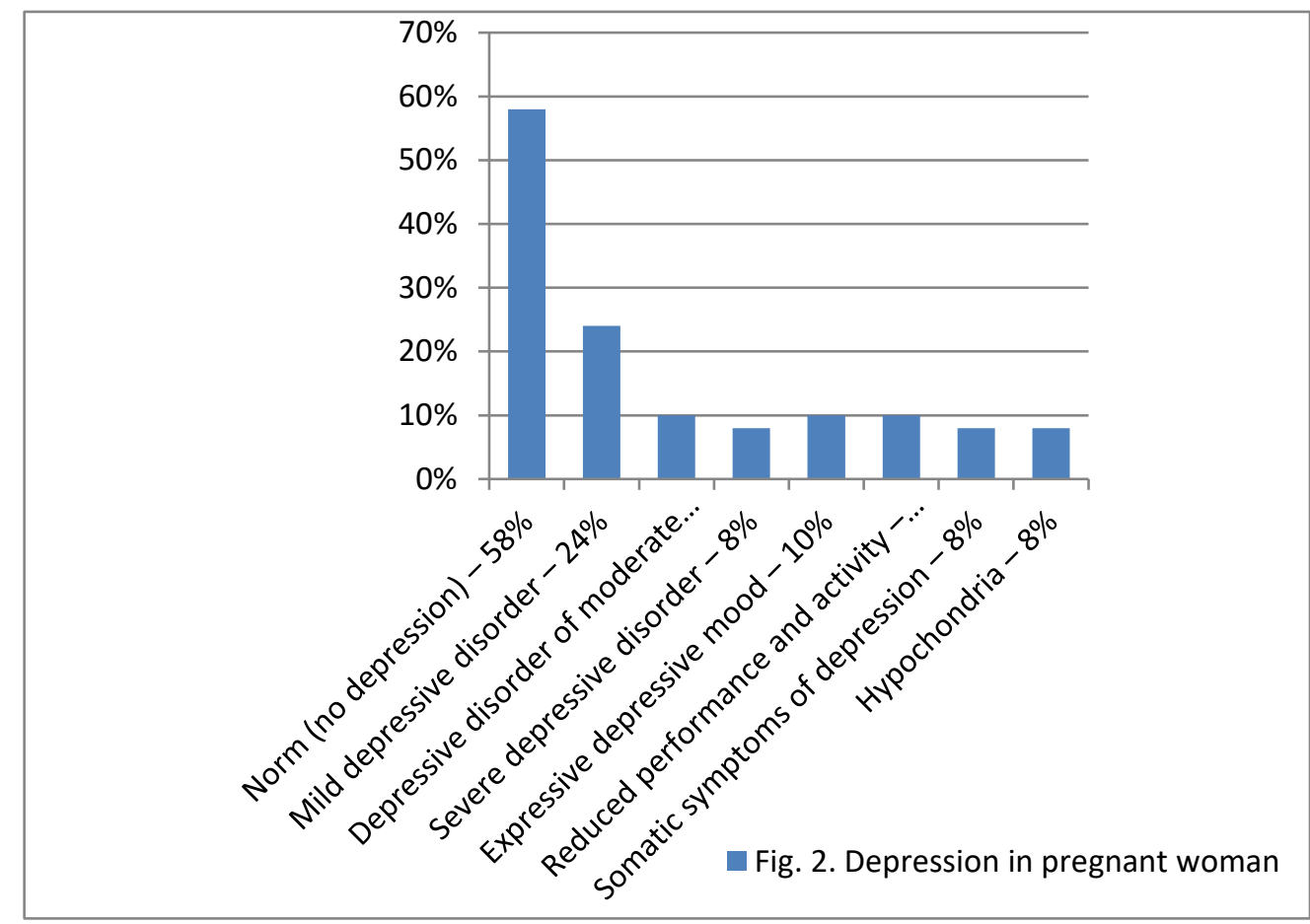

Expressive depressive mood, impaired ability to work and passivity are manifested in $10 \%$ of pregnant women, clear somatic symptoms of depression and hypochondria (excessive anxiety due to their own health) - in $8 \%$.

The following results were obtained regarding the distribution of depression in pregnant women of different ages (Table № $3)$.

Table 3. Depression in pregnant woman of different ages

\begin{tabular}{|c|c|c|c|c|c|c|c|c|c|c|}
\hline \multirow{2}{*}{ Age } & \multicolumn{2}{|c|}{$\begin{array}{c}\text { Total } \\
(n=100)\end{array}$} & \multicolumn{2}{|c|}{$\begin{array}{l}\text { Age under } \\
20 \text { years } \\
(n=25)\end{array}$} & \multicolumn{2}{|c|}{$\begin{array}{c}\text { Age } 20-29 \\
\text { years } \\
(n=35)\end{array}$} & \multicolumn{2}{|c|}{$\begin{array}{c}\text { Age } 30-39 \\
\text { years } \\
(n=35)\end{array}$} & \multicolumn{2}{|c|}{$\begin{array}{c}\text { Age over } \\
40 \text { years } \\
(n=5)\end{array}$} \\
\hline & $\mathbf{n}$ & $\%$ & $\mathbf{n}$ & $\%$ & $\mathrm{n}$ & $\%$ & $\mathrm{n}$ & $\%$ & n & $\%$ \\
\hline $\begin{array}{l}\text { Norm (no } \\
\text { depression) }\end{array}$ & 58 & $58 \%$ & 16 & $64 \%$ & 23 & $65,7 \%$ & 19 & $54,3 \%$ & & \\
\hline
\end{tabular}


"SOCIALIZATION \& HUMAN DEVELOPMENT" INTERNATIONAL JOURNAL

\begin{tabular}{|l|l|l|l|l|l|l|l|l|l|l|}
\hline $\begin{array}{l}\text { Mild } \\
\text { depressive } \\
\text { disorder }\end{array}$ & 24 & $24 \%$ & 6 & $24 \%$ & 7 & $20 \%$ & 9 & $25,7 \%$ & 2 & $40 \%$ \\
\hline $\begin{array}{l}\text { Depressive } \\
\text { disorder of } \\
\text { moderate } \\
\text { severity of } \\
\text { depression }\end{array}$ & 10 & $10 \%$ & 2 & $8 \%$ & 3 & $8,6 \%$ & 3 & $8,6 \%$ & 2 & $40 \%$ \\
\hline $\begin{array}{l}\text { Severe } \\
\text { depressive } \\
\text { disorder }\end{array}$ & 8 & $8 \%$ & 1 & $4 \%$ & 2 & $5,7 \%$ & 4 & $11,4 \%$ & 1 & $20 \%$ \\
\hline $\begin{array}{l}\text { Symptoms of } \\
\text { depression: }\end{array}$ & 10 & $10 \%$ & 1 & $4 \%$ & 4 & $11,4 \%$ & 3 & $8,6 \%$ & 2 & $40 \%$ \\
\hline $\begin{array}{l}\text { Expressive } \\
\text { depressive } \\
\text { mood }\end{array}$ & 10 & $10 \%$ & 1 & $4 \%$ & 2 & $5,7 \%$ & 4 & $11,4 \%$ & 3 & $60 \%$ \\
\hline $\begin{array}{l}\text { Reduced } \\
\text { performance } \\
\text { and activity }\end{array}$ & 8 & $8 \%$ & & & 2 & $5,7 \%$ & 2 & $5,7 \%$ & 4 & $80 \%$ \\
\hline $\begin{array}{l}\text { Somatic } \\
\text { symptoms of } \\
\text { depression }\end{array}$ & 8 & $8 \%$ & & & 2 & $5,7 \%$ & 3 & $8,6 \%$ & 3 & $60 \%$ \\
\hline Hypochondria
\end{tabular}

Pregnant women aged 20-29 years are also most characterized by the absence of depression $(65.7 \%)$, and another $20 \%$ have mild depressive disorder. At the same time $11.4 \%$ of pregnant women of this age have a distinct depressive mood (depression, helplessness, feelings of inferiority).

More than half of pregnant women aged 30-39 years have no depressive symptoms. However, $25.7 \%$ of women of this age are characterized by mild depressive disorders, and $11.4 \%$ have severe depression. Expressive depression and hypochondria (excessive anxiety due to health) are characteristic of 3 women
$(8.6 \%)$, and 4 women (11.4\%) have decreased ability to work and passivity.

Analyzing the responses of pregnant women over the age of 40 , we note the prevalence of mild to moderate depression in most of them ( $40 \%$ each) and the finding of severe depression in $20 \%$ of women of this age. In this case, $80 \%$ have clear common somatic symptoms, $60 \%$ have reduced performance and lack of activity, hypochondria (excessive anxiety due to health), and $40 \%$ have a clear depressive mood.

At different trimesters of pregnancy, women exhibit a different tendency for depressive states (Table 4):

Table 4. Depression in pregnant woman at different trimesters

\begin{tabular}{|l|c|c|c|c|c|c|}
\hline \multirow{2}{*}{ Trimester } & \multicolumn{1}{c|}{$\begin{array}{c}\text { I Trimester } \\
(\mathbf{n = 3 5 )}\end{array}$} & \multicolumn{2}{c|}{$\begin{array}{c}\text { II Trimester } \\
(\mathbf{n = 4 0})\end{array}$} & \multicolumn{2}{c|}{$\begin{array}{c}\text { III Trimester } \\
(\mathbf{n}=\mathbf{2 5})\end{array}$} \\
\cline { 2 - 8 } & $\mathbf{n}$ & $\mathbf{\%}$ & $\mathbf{n}$ & $\mathbf{\%}$ & $\mathbf{n}$ & $\%$ \\
\hline Norm (no depression) & 20 & $57,1 \%$ & 24 & $60 \%$ & 14 & $56 \%$ \\
\hline Mild depressive disorder & 10 & $28,6 \%$ & 8 & $20 \%$ & 6 & $24 \%$ \\
\hline
\end{tabular}


"SOCIALIZATION \& HUMAN DEVELOPMENT" INTERNATIONAL JOURNAL

\begin{tabular}{|l|l|l|l|l|l|l|}
\hline $\begin{array}{l}\text { Depressive disorder of moderate } \\
\text { severity of depression }\end{array}$ & 4 & $11,4 \%$ & 4 & $10 \%$ & 2 & $8 \%$ \\
\hline Severe depressive disorder & $\mathbf{1}$ & $\mathbf{2 , 9 \%}$ & $\mathbf{4}$ & $\mathbf{1 0 \%}$ & $\mathbf{3}$ & $\mathbf{1 2 \%}$ \\
\hline Symptoms of depression: & & & & & & \\
\hline Expressive depressive mood & 4 & $11,4 \%$ & 4 & $10 \%$ & 2 & $8 \%$ \\
\hline Reduced performance and activity & 4 & $11,4 \%$ & 3 & $7,5 \%$ & 3 & $12 \%$ \\
\hline Somatic symptoms of depression & 1 & $2,9 \%$ & 3 & $7,5 \%$ & 4 & $16 \%$ \\
\hline Hypochondria & 3 & $8,6 \%$ & 2 & $5 \%$ & 3 & $12 \%$ \\
\hline
\end{tabular}

Most pregnant women do not have depressive symptoms $(57.1 \%$ of women in the first trimester, $60 \%$ of women in the second trimester, $56 \%$ of women in the third trimester). However, mild depressive disorder manifests in $28.6 \%$ of women in the 1 st trimester, in $20 \%$ of women in the second trimester, in $24 \%$ in the third trimester. Medium-severity depressive disorder is most characteristic of women in the 1 st trimester $(11.4 \%)$, while and third trimester $(12 \%)$.
At the same time, expressive depressive mood is observed in $11.4 \%$ of women in the $1 \mathrm{st}$ trimester, reduced performance and passivity are manifested in $11.4 \%$ of women in the first trimester and $12 \%$ of women in the third trimester. And the clear general somatic symptoms of depression are prevalent in women in the third trimester $(16 \%)$, also these women are most characterized by hypochondria (excessive anxiety about their health and baby's health).

Table 5.Relations between features of pregnant woman and presence of depression

\begin{tabular}{|c|c|}
\hline Features & $\begin{array}{c}\text { Pearson correlation coefficient } \\
\text { (to presence of depression) }\end{array}$ \\
\hline Age &, $385^{*}$ \\
\hline Trimester &, $419^{* *}$ \\
\hline
\end{tabular}

(** indicates significant correlation with a $99 \%$ confidence level and * indicates significant correlation with a $95 \%$ confidence level.)

\section{Discussion}

The issue of diagnosing emotional conditions in women during pregnancy is currently very acute in the field of obstetrics and psychodiagnosis. Over the last 10 years, the issues of anxiety and depressive disorders during pregnancy have been raised several times in national science, which means that there is no proper level of development of this issue. The main objective of our study was to show that the problem of depression in pregnant women is, even if it is silent and ignored. Our goal is to introduce a psychodiagnostic background in maternity hospitals, to introduce the principle of emotional involvement of a doctor in obstetric practice, to develop current studying programs for this issue.

In foreign science, the level of development of the issue of emotional problems in pregnant women is higher. There are studies that indicate that women who have a high level of anxiety or depression during pregnancy have children with different neurological problems in the future: mental retardation, delayed language development, stuttering, enuresis, fears, emotional lability. (Zabolzaeva, Kozlova, Cherny`sheva, 1998) 
"SOCIALIZATION \& HUMAN DEVELOPMENT" INTERNATIONAL JOURNAL

Also important is the fact that in most cases postpartum depression has its manifest during pregnancy, but due to inadequate diagnosis, it goes unheeded. (O’Hara, Zekoski, Philipps, 1990)

\section{Conclusion.}

The development of depressive and anxiety disorders of the non-psychotic registry may be conditioned by the specific personality characteristics of women in combination with the disturbance of the interpersonal relationships system, unreacted past stressful influences and complex social factors that lead to poor quality of life. Special attention should be paid to the experts on the occurrence and exacerbation of anxiety - depressive disorders and neurotic reactions to stress at different stages of pregnancy.

Our study and a lot of literature about medical and psychological aspects of pregnancy have shown that anxiety and depression in women during pregnancy require early detection and correction due to their significant negative impact on pregnancy, childbirth, postpartum and further psychophysical development and social adaptation of children.

Anxiety and depression disorders in women during pregnancy can be predictors of anxiety and depression disorders in Mother during the first year of motherhood and postpartum period at all.

Today there are many methods of prevention and overcoming of depressive disorders, developed within various therapeutic schools. Because depression in all its typical features is deeply individual in nature, building a strategy for its elimination and prevention requires the selection of methods that are most relevant to the psychological characteristics of each client. Formation of qualities in a person that will provide her personal stability with the effect of depressogenic factors are psycho-psychological factors relapses.

\section{References}

Bárbara Figueiredo, Ana Conde (2011). Anxiety and depression symptoms in women and men from early pregnancy to 3-months postpartum. Journal of affective disorders, No. 132, 146-157.

Beck C.T. (1996). A meta-analysis of predictors of postpartum depression. PubMed, No. 45, $297-$ 303.

Eydemiller E.G., Dobryakov I.V., Nikolskaya I.M. (2003). Semeynyiy diagnoz i semeynaya psihoterapiya: ucheb. posobie. SPb: Rech.

Evans J.(Ed.). (2001). Cohort study of depressed mood during pregnancy and after childbirth. BMJ, 323, 257.

https://doi.org/10.1136/bmj.323.730 7.257

Filippova, G.G. (Ed.). (1996). Razvitie materinskogo povedeniya $\mathrm{V}$ ontogeneze. Psihologiya segodnya.

Ezhegodnik Rossiyskogo psihologicheskogo obschestva, 3, 133.

Filippova, G.G. (Ed.). (2002). Psihologiya materinstva: ucheb. posobie. Moskva: Yzd-vo Ynstytuta Psykhoterapyy.

Kolesnikov I. (2012). Nevroticheskie depressivnyie rasstroystva $i$ semeynoe funktsionirovanie $u$ beremennyih zhenschin. Retrieved from HTTP://MPRJ.RU/ARCHIV GLOBAL/2012 5 16/NOMER/NO MER05.PHP

McNeil T.F., Blennow G. A. (1988). Prospective study of postpartum 
"SOCIALIZATION \& HUMAN DEVELOPMENT" INTERNATIONAL JOURNAL

psychoses in a highrisk group.

Relationship of birth complication and neonatal abnormality. Acta

Psychiatrica Scandinavica, 78, 613617.

Nechaeva, M.A. (2005). Psihologicheskie faktoryi ontogeneza materinskoy sferyi, vnutrenney kartinyi beremennosti i perinatalnogo razvitii. Chelyabinsk:YUrGU.

O'Hara M.W., Zekoski E.M., Philipps L.H. (1990). Controlled prospective study of post-partum mood disorders: comparison of childbearing and nonchildbearing women. J Abnorm Psychology, 99, 3-15.

Pushkareva T.M. (2005). Poslerodovaya depressiya: rasprostranennost, klinika, dinamika. Kyiv: Psihichne zdorov'ya.
Pushkareva T.M. (2017). Algorytm skryningovoyi diagnostyky depresyvnyx ta tryvozhnodepresyvnyx rozladiv u zhinok pid chas vagitnosti ta pislya pologiv. Kyiv: Zdorov`e zhenschynu, 1, 6266.

Targum S.D. (1979). Dealing with psychosis during pregnancy. JAPhA, Vol. 9, 18-21. https://doi.org/10.1016/S01603450(15)32299-6

Zabolzaeva I.V., Kozlova M.A., Cherny`sheva L.V. (1998). Vliyanie psikhotravmiruyushhikh situaczij vo vremya beremennosti na dal nejshee razvitie rebenka. SPb: Akademiya mediko-soczial nogo upravleniya. 
"SOCIALIZATION \& HUMAN DEVELOPMENT" INTERNATIONAL JOURNAL

\title{
FEATURES OF BEHAVIOR OF ADOLESCENTS FROM FAMILIES WITH DIFFERENT TYPES OF UPBRINGING AND PARENTHOOD
}

https://doi.org/10.37096/SHDISJ-19-1.1-0000

Onyshchenko Vitalii

ORCID: 0000-0002-4373-5256

\begin{abstract}
Absract
The aim of this study was to investigate the relationship between the type of family upbringing and adolescent deviant behavior. The study was conducted in 2019 at the Ukrainian Physics and Mathematics Lyceum of Taras Shevchenko National University of Kyiv and was based on a survey of 60 families, namely 60 adolescents aged 14-16 and their parents (60 persons). Standardized questionnaires were used: the Questionnaire to determine the propensity for deviant behavior (O.M. Orel), the Questionnaire of paternity types (V.B. Shapar), the Questionnaire for the analysis of parental family relationships (ASV) (EG Eidemiller, V. Justicis). The main results of theoretical and empirical researches of influence of family on formation of deviant behavior of teenagers are covered in the article. Deviant behavior is the result of restructuring of the body, the transition from childhood to adulthood, which is manifested in all aspects of human development during this period. In this case, deviations in the behavior of adolescents are manifested in the commission of destructive, conflicting, asocial and aggressive actions. Objective factors of increase in the number of adolescents with deviant behavior were clarified: worsening social situation; increasing the number of families living in difficult or unsatisfactory conditions; application of conflict and asocial styles of education, transfer of responsibility for the development of the child to other institutions of socialization. Next deviations in adolescent behavior are empiricaly identified: addictive, aggressive, delinquent behavior, violations of rules and rules. Characteristic features of the above-mentioned forms are trends in alcohol and drug use, uncontrolled manifestations of aggression, violence, violation of generally accepted norms and rules that function in society, which in the future may lead to the commission of unlawful acts by adolescents. The article presents the results of the implementation of a comprehensive program of correction of adolescent deviant behavior.
\end{abstract}

Keywords: parenting style, teenage addictiveness, delinquent behavior, norm violation, deviant behavior.

\section{Introduction}

The problem of deviant behavior in modern Ukrainian society is very urgent. This is one of the most important scientific problems of psychology, pedagogy, sociology of deviant behavior, psychology of personality and more. This type of behavior is a consequence of social, economic and cultural factors. This is due to the fact that during this period there is a process of body restructuring, the transition from childhood to adulthood, maturity, which touches on all aspects of adolescence. Deviation from adolescence has become a particularly urgent problem in recent decades. There is a steady increase in the number of adolescents with deviant behavior, characterized by 
"SOCIALIZATION \& HUMAN DEVELOPMENT" INTERNATIONAL JOURNAL

committing destructive, conflict, asocial, aggressive actions.

The purpose of the presented study is to examine the relationship between type of family education and adolescent deviant behavior.

\section{Theoretical background}

A review of scientific sources showed that the focus of attention of scientists (I. Bech, N. Bulatevich, L. Zhuravleva, O. Zaporozhets, N. Kalina, A. Mambetova, Y. Ryabchich, O. Vlasova, E. Prokopovych, L. Volnova , E. Zmanovskaya and others) remains central to the impact of family on adolescent behavior. An increase in the number of adolescents with deviant behavior is associated with a worsening social situation, which has led to an increase in families living in difficult or unsatisfactory conditions, an increase in families with conflicting and asocial parenting styles, an increase in the number of families transitioning to development and development. the child to other institutions of socialization.

One of the most common problems among today's youth is the rise in the number of offenses, the increase in violence and addictive behavior among adolescents. It is adolescents who find themselves in a difficult situation due to the lack of their own formed system of stable moral convictions, value orientations, which prevents them from reacting normally to events occurring in the environment.

Deviance (from the Latin word deviatio - deviation) means the actions and actions of people who contradict norms or certain patterns and standards of behavior. The essence of deviant behavior lies in the failure to meet the requirements of social norms, in the choice of another variant of behavior, different from the one adopted in a certain situation, which leads to disruption of the interaction of personality and society.

In psychology, deviant behavior is a deviation from the norms of interpersonal relationships adopted in a particular society over a particular historical period. Negative deviations in human behavior are characterized by the fact that the individual does not acquire a positive experience, is not able to adapt to the norms of behavior adopted in society. Knowledge of the necessary social norms by a person and at the same time their non-compliance testifies to the violation of the socialization process. It is characterized by an imbalance of the processes of the psyche, the inability to adapt to changes in the environment.

OV Zmanovskaya distinguishes the following characteristic features of deviant behavior:

1) repeated, continuous violations of the most important norms and values for a particular society;

2) behavior is conditioned by the general orientation of the individual, not by a crisis, non-standard situation;

3) the behavior is accompanied by various manifestations of social maladaptation, causes negative evaluation by other people;

4) the behavior results in causing real harm to the individual or others (Zmanovskaya, 2003).

The limits of behavior violations are difficult to determine. After all, the transformations that take place in society cause changes in social norms. Therefore, at the social level, behavior with deviations is a form of interaction between society and the individual; it is the persistent behavior of a person who does not conform to social norms, harms the society or the individual 
himself and is accompanied by his social maladaptation. At the personal level, such behavior is a social position, the basis of which is the desire for a deviant style and lifestyle. In the future, this leads to conflict with the social environment, selfdestruction, loss of social contacts and further social maladaptation.

- In general, the psychological manifestations of deviant personality behavior include the following:

- $\quad$ spiritual problems (loss of meaning of life, appearance of inner emptiness);

- deformation of the valuemotivational sphere (characterized by unformed or weakening of moral values, frustration, experiencing internal conflicts);

- emotional problems (eg anxiety or depression, dominance of negative emotions, alexithymia (difficulty in understanding one's own emotions, inability to express them in words), emotional coarsening;

- cognitive distortions (stereotypical, rigid thinking, inadequate attitudes, prejudices);

- negative life experience (presence of mental trauma, experience of violence, negative habits (Azarova, 2009).

- Features of manifestation of deviant behavior in adolescents are found in:

- resisting requests, demands, tips;

- conscious unwillingness to act morally;

- non-motivated, unjustified resistance;

- opposing requests, tips;

- unwillingness, inability to understand oneself;

- ignoring obstacles to selfaffirmation.
- The process of formation and further development of deviant behavior consists of the following stages:

1) the first stage (situational). At this stage, only some symptoms of deviant behavior are manifested, such as non-compliance with certain social requirements, disobedience;

2 ) in the second stage (persistent violations) there is a non-observance and persistent violation of moral and social and norms, characteristic for the given society, possible manifestations of delinquent behavior, which further leads to offenses;

3) the third stage is characterized by the accumulation of the experience of committing criminal acts and approaching them to the criminal ones (theft, violence). The "crisis of identification" (contradictions and misconceptions about oneself and the thoughts of others), which often arises, often causes acute intrapersonal conflict. As a result, the individual begins to perceive their behavior as normal;

4) the fourth stage of deviance is characterized by repeated manifestations of persistent, socially dangerous behavior, joining groups characterized by asocial and antisocial behavior;

5) in the last, destructive stage, a person, especially dangerous deviant behavior, is observed in humans. Characteristic are serious social deviations, separated by the constant alienation of the individual from the social environment and inherent norms and values (Mendelevich, 2005).

The general scientific approach 
"SOCIALIZATION \& HUMAN DEVELOPMENT" INTERNATIONAL JOURNAL

to the classification of behavioral disorders distinguishes the following types and characteristics of deviations:

- "by nature: mental, physical, social (cultural), economic disorders, etc .;

- Degree of deviance: primary (any form of abusive behavior) and secondary (arising from the conscious or unconscious desire of the deviant to act in accordance with the "label" that others have labeled their behavior that took place earlier);

- on the scale of deviance: mass (such as alcoholism), group (behavior of sports fans or music fans), individual or isolated (narcissism, train disturbance kleptomania, etc.);

- by subject of deviance: rejection of individuals (alcoholic woman, suicide), official structures, informal and conditional social groups (anonymous alcoholics, fans, informal, etc.);

- on the duration of deviations: temporary (episodic, for example, influenced by a group) and long (constant);

- on the dynamics of deviance: stable when only one type of asocial behavior (drug addiction, dromomania, etc.) is manifested; unstable when there is a tendency to manifest different types of deviant behavior (alcoholism with aggression towards others, etc.);

- by type of violation and significance of consequences: negative deviations socially disapproved, potentially destructively dangerous for the development of society and the individual (drug addiction, suicide, murder, etc.); positive deviations are socially approved, that is, promoting progress, social development, and personal growth (nonstandardism and progressiveness in political or economic activity);

- in the focus on themselves and others: expansive - invasion of the spheres of life and activity of others, the implementation of various forms of physical, mental and sexual abuse against them; non-expansive - the individual's behavior does not affect the interests of others, but harms themselves (eg, anorexia nervosa); selfish - aimed at pleasure or personal pursuit (sexual deviance, substance abuse); altruistic - directed at the interests of others, often combined with a tendency to self-sacrifice (suicidal behavior of a person committed for the sake of loved ones or the deity he worships, or "for the sake of all mankind");

- on the level of awareness and critical behavior: conscious deviations, when a person realizes that his actions are contrary to certain norms, may experience negative emotions about this, wishes to change his behavior; unconscious deviations are usually inherent in people with mental disorders who are convinced that their behavior is adequate;

- in terms of the structure of deviations: structured (organized) is a group form of behavior within which the roles of all its participants (sectarianism) are clearly distributed; unstructured deviations are characterized by the absence of hierarchical relationships, the regulation of actions "(Volnova, 2009).

Psychological approach to the issue of classification of deviance is based on the selection of socio-psychological differences in types of behavior of a person (Zmanovskaya, 2010).

The overall structure clearly identifies a group of causes that determine the occurrence of deviant behavior in adolescents: socioeconomic, psychological - pedagogical, and medical - biological (Koshova, 2009). 
"SOCIALIZATION \& HUMAN DEVELOPMENT" INTERNATIONAL JOURNAL

One of the dominant factors that influence the emergence and further development of deviant behavior in adolescence is the family environment and all the processes and phenomena that develop in it. The family is the starting point for the formation and development of the individual, so it should maximize the adaptation of the individual who is in it to the conditions of social life, as well as prepare the ground for adoption by the teenager of social norms (Zubkov, 2011).

The formation of deviance in adolescence is based on all of the above factors, which interact to cause the emergence and further development of deviant behavior in adolescence.

The family is the most important primary environment that has a dominant influence on the formation and development of the individual. It is a process of assimilation of social norms and values, the need for love, security, attention, belonging, the experience of interpersonal relationships is accumulated. The family performs functions such as upbringing, housing, material and economic, primary social control, communicative, emotional, regulatory.

If the needs of the teenager are not met and the family functions are not fulfilled, this can lead to extremely negative consequences. There is a disruption of the process of socialization, and there may be various abnormalities and disorders related to physical and mental development. It is under these conditions that the deviant behavior is formed and further developed. The most characteristic of these types of families, such as families at risk, in this category are socially disadvantaged families in need of social assistance and support, such as lowincome, multi-child, disabled children, incomplete; Asocial families, this type of families is characterized by heavy interaction, their condition requires fundamental changes, in such families, the adult family environment leads an immoral, unlawful lifestyle; disadvantaged families, such families are characterized by disturbed structure, lack or blurring of internal boundaries, they undergo a process of depreciation or neglect of basic family functions, defects in education that cause disturbance of the psychological climate in the family. Each of the above categories deliberately causes the formation of different types of abnormalities in children. As a result, the child does not know how, or is not able to behave reasonably in society, characterized by the lack of love, understanding, support from the parents.

In order to determine adolescents' predisposition to deviant behavior, to measure predisposition to various forms of deviance, to identify errors in the process of family education and types of family education that may cause deviant behavior in adolescents, we conducted a study.

\section{Methodology}

To investigate the selected problem, we used standardized questionnaires:

Questionnaire for determining predisposition to deviant behavior (OM Orel). The main purpose of the technique is to diagnose the predisposition to deviant behavior, to measure the predisposition of adolescents to perform various forms of deviance. The technique involves taking into account the setting of the socially desirable responses of the subjects. In this technique, the scales are divided into substantive and official. Content scales are aimed at measuring the psychological content of a complex of related forms of deviant behavior (social and personal attitudes that determine these behavioral 
"SOCIALIZATION \& HUMAN DEVELOPMENT" INTERNATIONAL JOURNAL

manifestations). The service scale aims to measure the propensity of the respondent to provide socially desirable answers, a general assessment of the reliability of the answers received (Nabiullina, 2008).

Questionnaire for parents "Types of parenting", VB Shapar. Using this questionnaire allows you to find out the type of family upbringing observed in the family environment of counting. When accentuating several types of family upbringing, it can be concluded that there is a contradictory upbringing in the family, which in turn may be the cause of the emergence and development of deviance in adolescents (Bondarchuk, 2001).

Questionnaire for Parents "Analysis of Family Relationships"

(ACS)

(Eidemiller E.G., Yustitskis V.V.). The use of this technique is conditioned by the possibility of detection by the questionnaire of errors in the process of family education and types of family education that can cause deviant behavior in adolescents. This technique is aimed at identifying the type of parental education and finding errors in it. It helps to diagnose dysfunction in the system of mutual influence of family members, disorders in the structural and role aspect of family life and in the mechanism of its integration (Panok, 2001).

The study was conducted during 2019 at the Ukrainian Physics and Mathematics Lyceum of Taras Shevchenko National University of Kyiv and was based on a survey of 60 families, namely 60 adolescents aged 14-16 years and 60 parents who are parents or guardians of adolescents.

\section{Results}

The results of the study can be divided into two directions. The first is aimed at diagnosing adolescents, namely their propensity for deviant behavior and their relationship to the family environment. The second is aimed at the diagnosis of parents, the types of family upbringing and the cause of deviations in the educational process.

The study found that adolescents are prone to such forms of deviance as violations of rules and regulations (57.3 b), addictive behavior $(58.5 \mathrm{~b})$, aggressive behavior (54.3 b), volitional control (55, 6 b), delinquent behavior (53.4 b. Grades above 50 points indicate abnormality) (see Figure 1). The results of the ADOR questionnaire indicate a lack of positive interest on the part of parents and the family environment in adolescents, the passive role of parents in the upbringing of children, the manifestation of hostile and aggressive position on the part of parents.

In the study of types of family upbringing it was found that the dominant types are (according to the results of the questionnaire "Types of upbringing of children", VB Shapar): hypoopic (6.1), neglect (5.9), Cinderella (5.4), contradictory upbringing (5.1). According to the EIA (Eidemiller E.G., Yustitskis V.V.), dominant types of education such as hypoprotection and emotional rejection were identified. The main causes of disturbances in the educational process are the underdeveloped parental feelings (6.33), the projection of the adolescent's own undesirable qualities (3.17), parental insecurity (2.17).

Analyzing the results of VB Shapar's questionnaire "Types of child-rearing", a significant correlation was found between the presence of deviant behavior and such types of family education as hypoopic (0.61), homelessness (0.58), "idol of family" ( 0.50$)$, Cinderella $(0.51)$, 
"SOCIALIZATION \& HUMAN DEVELOPMENT" INTERNATIONAL JOURNAL

Hedgehog Mittens (0.54), Controversial Education (0.52), Hyperopic (0.56).

In the analysis of the results of questionnaires (ACS) (EG Eydemiller, VV Yustitskis) a direct correlation between deviant behavior of adolescents and hyperprotection (0.62), hypoprotection $(0.51)$, excess of requirements-prohibitions $(0.50)$.

In order to correct the deviant behavior of adolescents, a training program for adolescents aged 14-17 years was developed, which is designed for 10 classes. The purpose of the program - to promote the formation of self-control skills, the achievement of positive changes in behavior, the correction of manifestations of deviant behavior, the formation of skills of reflection. Legal work with parents of teenagers was also conducted.

The objectives of the program were: diagnosis of adolescents' predisposition to deviant behavior; facilitating the creation of a personal scale of deviant behavior that will allow you to get an idea of the optimal response styles in different situations; assistance in the formation of self-control skills, control of the emotional sphere; formation of self-examination skills, conscious correction of one's behavior.

Forms and methods of work were chosen information, testing, reassessment, "brainstorming", psychological games and exercises, role-playing situations, training games, projective drawing techniques.

Exercises "Dating", "Who I am", "Group interview", "I'm pleased when ..." intended to familiarize participants with the conditions of work of the training group and to create rules of work of the group, to create a positive atmosphere, to create rules of work in the group, to acquaint the participants with the diagnosis of addiction.
Cheers Compliment, Greetings and Mood, Self-Test, Self-Exercise, Brainstorming What Hinders Me? aimed at establishing trust and understanding between members of the group, developing self-examination, and forming a culture of self-reflection.

The analysis of the causes of aggression in our lives, the urge to reflect on the expediency of aggressive behavior were conducted through the diagnosis of aggression, exercises "Communication with an aggressive interlocutor", "I do not tolerate ...", "Cardboard lock", "Auction", "Wishes on $»$.

Getting acquainted with your own misdeeds and petty guilt, playing a problematic situation, finding a solution, removing emotional and physical tension were performed using the exercises "Conflict Chair", "Figure deviation of norms of behavior", "Fire-ice" and information message on the topic: "Deviant and delinquent behavior of adolescents and their consequences".

The informational message "Life Values", exercise "Life Values", game "Account for ten", exercise "Suitcase on the road", exercise "Give a smile to a friend" were aimed at creating conditions for adolescents to appeal to their own value and sense sphere.

Formation of skills of adequate evaluation of others, opening of internal problems for further work with them, release of negative emotions, assessment of internal state of participants was carried out by means of exercises "Image of emotions", "Feedback", "Create personal scale of truancy", "Create personal a healthy lifestyle scale. "

The development of constructive means of controlling one's behavior, awareness of oneself from the position of 
"SOCIALIZATION \& HUMAN DEVELOPMENT" INTERNATIONAL JOURNAL

leader and formation of cooperation skills, developing patience for the shortcomings of others were realized through exercises "Confusion", "Silent cry", "King" and informational message on the topic: "Alternative to violation" .

Exercises "Beginner", "Love Anger", "Social Masks", "Icons", "Compote" aimed to identify the causes of violations of the norms of behavior, the formation of the ability to find positive behavioral reactions and experiences, play roles and learn different behavior strategies in conflict situations, giving the opportunity to see conflict situations from different sides.

Playing conflict situations, finding a constructive way out of them, enhancing knowledge on finding a way out of problematic situations, raising self-esteem, creating a positive mood were implemented through exercises "Mirror", "Carpet of Light", "Exit!", "Self-praise" and information message: "Managing your emotions".

Exercises "Sculpture", "I want to tell my colleague", "I am in the past. I do now. I'm in the Future", "Journey to the Future "were used to summarize, receive training performance information from training participants, receive feedback from training participants, reflections, re-diagnose addiction addiction, complete group interaction.

An important factor in correcting deviant behavior in adolescence is information work with parents of adolescents. This part of the correction included information and legal work and touched upon the following issues: informing parents about the concept of deviant behavior, its manifestations and consequences; informing on the responsibility (including criminal) for committing delinquent actions; research on the features of family upbringing in these families, information on the influence of this factor on the development of deviant behavior in adolescents.

After the training program, the adolescents' predisposition to deviant behavior was re-diagnosed and the results obtained were compared, which showed a decrease in the inclination level from an average of 54.76 before the program to 46.2 after the training program (see Figure 2) and for each of the indicators: rules and regulations (46.2), addictive behavior (51.2), self-destructive behavior (46.8), aggressive behavior (44.1), volitional control (45.4), delinquent behavior (43.4) (see figure) 1). 
"SOCIALIZATION \& HUMAN DEVELOPMENT" INTERNATIONAL JOURNAL

Fig. 1. Comparison of results of predisposition to deviant behavior in adolescents before and after training

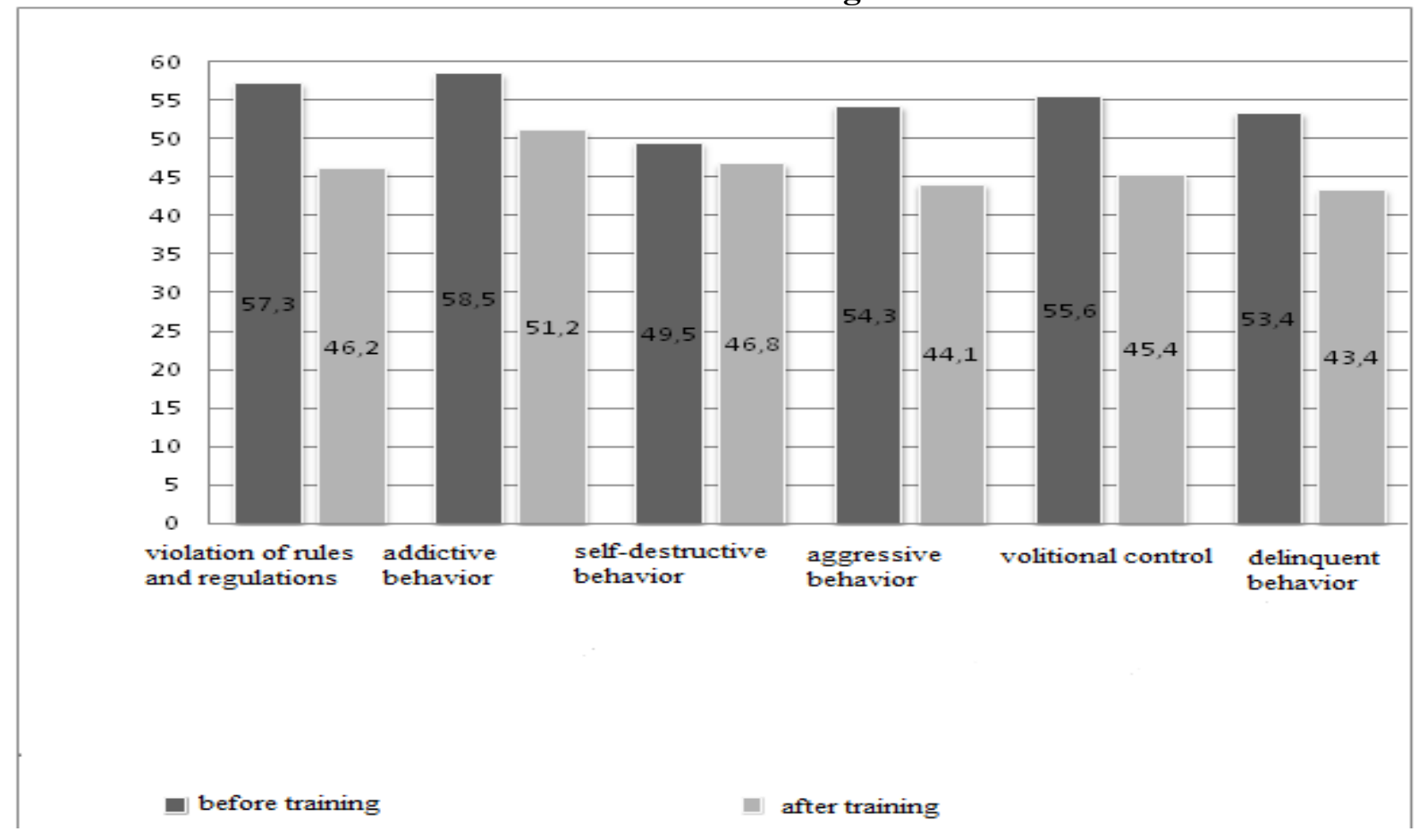

Fig. 2. Comparison of the average overall propensity for deviant behavior in adolescents before and after training

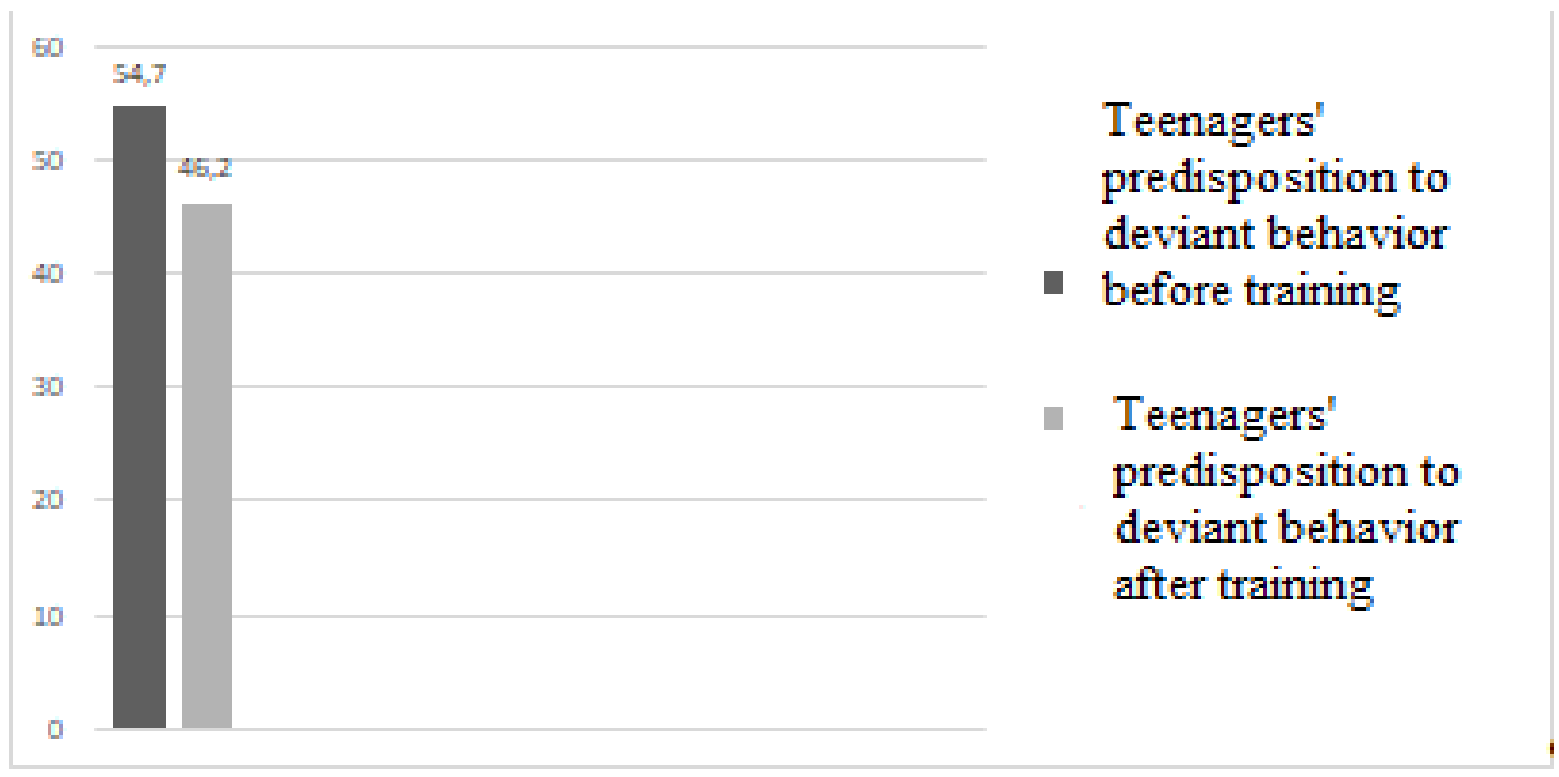

Comparing the results, we see a decrease in the propensity to implement various forms of deviant behavior in adolescents, which indicates the effectiveness of this training program and the relationship between the type of family education and deviant behavior of was conducted with adolescents. adolescents.

\section{Discussion}

The process of conducting our research was divided into two directions:

1. Conduct an empirical study on the predisposition to deviant behavior and their relationship to the family environment that 
"SOCIALIZATION \& HUMAN DEVELOPMENT" INTERNATIONAL JOURNAL

2. Conducting an empirical study with adolescent parents, whose main purpose was to identify types of family education and to identify errors in the process of family education.

In such a fundamental and comprehensive approach, in our view, the uniqueness of this study is in comparison with the work of other researchers (Zhuravl'ova, Kolomiets', 2013; Volnov, 2009).

The study was conducted in several stages. At the organizational stage, theoretical information concerning the problem of forming deviant behavior was elaborated. In the second stage, empirical research was conducted using standardized techniques. The next stage was the processing and interpretation of the results. Based on the results obtained, a training program was developed to correct deviant behavior in adolescents, which includes a comprehensive approach (work with adolescents and their parents). After the training, a retest was conducted regarding adolescents' predisposition to deviant behavior to obtain results regarding the effectiveness of the training program.

In addition, there are limitations to the results obtained. Yes, the study hypothesis was tested only on adolescents. However, it is also promising to study the more distant effects of parental parental influence - how it may manifest in adulthood, in relation to their children taken from their parental family, and in parent-child relationships already in the young family, and so on. Although similar studies already exist (Vlasova, 2019; Zhuravl'ova, Kolomiets', 2013; Zmanovskaya, 2010; Volnova, 2009), we have focused on the influence of parenting styles on adolescent deviant behavior formation and the development of a psychological program for normalizing adolescent behavior. This study opens up the potential for further scientific research and highlights the relevance of the chosen direction of scientific research.

\section{Conclusion}

As a result of a study of the influence of the family on the formation of deviant behavior in adolescents, we have established the following patterns. Teenagers with deviant behavior are characterized by resistance to the demands and demands of society, conscious unwillingness to behave (morally), resisting requests and advice, unwillingness, inability to understand others, ignoring obstacles to selfaffirmation, conscious, deliberate violations of society's rules and regulations.

An important factor in the emergence and development of deviant behavior is the family environment and the processes that take place in it. If there is a disharmonious type of upbringing in the family, destructive types of parenting, the risk of deviant behavior in their children is significantly increased. If the living needs of the family environment are not met, socialization is impaired, and various pathologies and abnormalities related to the physical and mental development of the adolescent may occur. It is under these conditions that deviant behavior is formed and developed.

The study found that adolescents' predisposition to various forms of deviant behavior has a direct correlation with such types of family upbringing as hypoopic, neglect and hyperopic, contradictory upbringing, emotional rejection, and cruel rejection.

Therefore, summarizing the results, it should be noted that the most common 
"SOCIALIZATION \& HUMAN DEVELOPMENT" INTERNATIONAL JOURNAL

forms of deviation are addictive, aggressive, delinquent behavior, violations of rules and regulations. Characteristic features of the abovementioned forms are trends in alcohol and drug use, uncontrolled manifestations of aggression, violence, violation of generally accepted norms and rules that function in society, which in the future may lead to the commission of unlawful acts by adolescents. After applying the correction program, a decrease in adolescents' predisposition to deviant behavior was recorded. This encourages us to continue our study of selected issues and to create and improve correctional programs, which opens the prospects for our further research.

Gratitude. The study did not receive a grant from any financial agency in the public, advertising or non-profit sectors.

\section{References}

Azarova L.A. (2009). Psihologiya deviantnogo povedeniya [Psychology of deviant behaviour]. Minsk. GIUST BGU [in Russian].

Bondarchuk O. I. (2001). Psykholohiia simi: Kurs lektsii [Family Psychology: A Lecture Course]. K.: MAUP [in Ukrainian].

Bondarchuk O. I. Psykholohiia simi: Kurs lektsii. - K.: MAUP, 2001

Bratchenko S.L. (1997). Diagnostika lichnostno-razvivajushhegosja potenciala. Metodicheskoe posobie dlja shkol'nyh psihologov [Diagnostics of personalitydeveloping potential. Methodical manual for school psychologists.]. Pskov. S. 34 -56. [in Russian].

Bulatevich N., Mambetova A. (2018). Psychological peculiarities of parenthood apprehensions of Ukrainians and Crimean Tartars. International Journal of Education \& Development, 1, 13 - 24.

Duhnovskij S.V. (2009). Diagnostika mezhlichnostnyh

Psihologicheskij

[Diagnostics otnoshenij. relationships. praktikum

Practical Training ] / Duhnovskij S.V. - SPb.: Rech'. 141. [in Russian].

Eliseev O.P. (2001). Praktikum po psihologii lichnosti [Practical work on personality psychology ]. $\mathrm{SPb}$.: Piter. 560. [in Russian].

Koshova, Inna Viktorivna. Psykholohiia deviantnoi povedinky : navch. posib. / Koshova I. V., Kresan O. D.; Nizhyn. derzh un-t im. M. Hoholia. - Nizhyn : Vyd-vo NDU im. M. Hoholia, 2009.

McLaughlin K. A., King K. (2015). Developmental trajectories of anxiety and depression in early adolescence. J. Abnorm. Child Psychol. 43 311-323. 10.1007/s10802-014-9898-1

Mendelevich V. D. (2005). Psikhologiya deviantnogo povedeniya : uchebn. posobiye [Psychology of deviant behavior: textbook]. SPb. Rech [in Russian].

Moilanen K. L., Rasmussen K. E., PadillaWalker L. M. (2015). Bidirectional associations between self-regulation and parenting styles in early adolescence. J. Res. Adolesc. 25 246-262. 10.1111/jora.12125

Nabiullina V.R. (2008). Tipy semeynogo vospitaniya i ikh raznovidnosti. Dopolnitelnoye obrazovaniye i vospitaniye [Types of family education and their varieties. Further 
"SOCIALIZATION \& HUMAN DEVELOPMENT" INTERNATIONAL JOURNAL

education and upbringing]. №11.

13s. [in Russian].

Nabiullina, V.R. Tipyi semeynogo

vospitaniya $i$ ih raznovidnosti //

Dopolnitelnoe obrazovanie i

vospitanie [Tekst] / V.R. Nabiullina.

- 2008. - \#11. - 13s.

Panok V. H., Tytarenko T. M., \& Chepelieva N. V. (2001). Osnovy praktychnoi psykholohii

[Fundamentals of practical psychology]. K.: Lybid [in Ukrainian].

Panok V. H., Tytarenko T. M., Chepelieva

N. V. Osnovy praktychnoi

psykholohii. - K.: Lybid, 2001

Prokopovych Y. (2017). Psykholohichna kharakterystyka mikrosotsialnykh chynnykiv internet-zalezhnoi povedinky pidlitkiv [Psychological characteristics of microsocial factors of adolescent Internetdependent behavior]. Visnyk Kyivskoho natsionalnoho universytetu imeni Tarasa Shevchenka. Psykholohiia Psychology, 2, 116 - 120 [in Ukrainian].

Riabchych I. (2018). Psykholohiia

obdarovanosti [Psychology of

giftedness]. Kyiv: «TsP

«KOMPRYNT» [in Ukrainian].

Van der Graaff J., Carlo G., Crocetti E., Koot H. M., Branje S. (2018). Prosocial behavior in adolescence: gender differences in development and links with empathy. J. Youth Adolesc. 47

1086-1099.

10.1007/s10964-017-0786-1

Van Lissa C. J., Hawk S. T., Koot H. M., Branje S., Meeus W. H. J. (2017). The cost of empathy: parentadolescent conflict predicts emotion dysregulation for highly empathic youth. Dev. Psychol.53 1722-1737. $10.1037 / \operatorname{dev} 0000361$

Vlasova O.I. (2019). Influence of internet dependency on youth selfactualization. Socialization \& Human Development: International Scientific Journal, 1, 1, 5-12.

Volnova L.M. (2009). Profilaktyka deviantnoi povedinky pidlitkiv : navch.-metod. posib. do spetskursu sots.-ped. tsyklu «Profilaktyka deviant. povedinky pidlitkiv» $\mathrm{K}$. Vyd-vo NPU im. M. P. Drahomanova [in Ukrainian].

Zhuravl'ova L.P., Kolomiec' T.V. (2013). Empatijna determinacija kognitivnih stiliv mizhosobistisnoji vzaemodiji $u$ junac'komu vici [The empathic determination of cognitive stiles of inter-personal interaction at the juvenile age ] // Problemi zagal'noji ta pedagogichnoji psihologiï: $\mathrm{Zb}$. nauk. prac' Institutu psihologiji im. G.S. Kostjuka APN Ukrajini, [za red. S. D. Maksimenka]. - K. T. XV, ch. 1. - S. $104-112$. [in Russian].

Zmanovskaya E.V.

(2003).

Deviantologiya. Psihologiya otklonyayushego povedeniya [Deviantology. Psychology of deviant behaviour]. M. Izdatelskij centr «Akademiya» [in Russian].

Zmanovskaya E.V. (2010). Deviantnoe povedenie lichnosti i gruppy [The deviant behavior of the individual and the group]. SPb. : Piter [in Russian].

Zubkov V. I. Deviantnost molodYozhi kak rezultat ee neadekvatnoy sotsializatsii / V. I. Zubkov // Sotsialno-gumanitarnyie znaniya. 2011. 
"SOCIALIZATION \& HUMAN DEVELOPMENT" INTERNATIONAL JOURNAL

\title{
REFLEXIVE ABILITIES TO SELF-REGULATION AS A COGNITIVE COMPONENT OF PERSONALITY'S PSYCHOLOGICAL WELL-BEING
}

https://doi.org/00.00000/SHDISJ-00-0.0-0000

\author{
Prokopovych Yevhenii \\ ORCID: 0000-0002-8601-5419 \\ Shykovets Serhii \\ ORCID 0000-0003-1299-6434
}

\begin{abstract}
The article is devoted to the theoretical and methodological investigation of the problem of the features of the reflexive abilities to self-regulation and the skills of students, which they use in the process of solving the problem, at the cognitive level of functioning of the reflective experience. Together with the theoretical analysis of scientific work related to the study of this topic, in the article we tried to operationalize them, that is, to select indicators that reflect the quantitative aspects of their formation, and to empirically determine the levels of students' ability to self-regulate and cognitively.

To determine the significance for students of the development of reflexive abilities to self-regulation, we used the scale "Tasks for the development of self-regulation abilities" from the methodology "Life tasks for self-development", developed by O. Savchenko and Y. Domanova, with which help determine the level of actualization of students' tasks through the regulation at the current time on the appropriate scales.

Using the method of O. Savchenko "Reflexive skills (cognitive level)" the generalized indicators of the average values of reflexive skills of the cognitive level were defined on such scales as "Ability to explain to yourself and others the course of their reasoning" emotional experiences, control their course, maintain a sense of confidence", "Keep yourself in the scope of reflections and analyze the reasons for their own actions, causes of failures", "Ability to organize the work the search for a solution, test their assumptions", "Ability to evaluate results by different criteria", "Ability to be aware of various aspects of the course of decision-making processes: cognitive, emotional, behavioral" and the overall level of development of reflexive ego skills. From the obtained data we can conclude that the students on average have the lowest assessment of their reflexive cognitive skills on the scale "Ability to evaluate results by different criteria, formulate evaluative judgments". The overall level of students' reflexive cognitive skills is medium.
\end{abstract} being.

Keywords: reflexive skills, educational activity, personality's psychological well-

Introduction.

In the light of the development of higher education of Ukraine towards the achievement of European standards of schooling and the attitude towards the student as a subject of educational activity, the development of their personal selfregulation at various levels should help to increase their level of psychological readiness for 
"SOCIALIZATION \& HUMAN DEVELOPMENT" INTERNATIONAL JOURNAL

educational and professional life, provided the timely definition and development of psychological qualities of the individual, which contribute to the development of personal self-regulation. Reflectivity as a process and reflection as a factor in the success of such an activity play an important role in this process. Therefore, it becomes necessary to investigate the connection between personal and cognitive qualities that, in combination with regulatory and reflexive capacity, ensure the success of students' learning process. Starting from the 80 s of the last century, great interest in psychological and pedagogical works has caused the study of problems of students' self-regulation, components, mechanisms, principles, factors of self-regulated learning, etc. Particularly relevant is the study of psychological features of components of self-regulated learning, namely: conscious setting of learning goals and objectives, the use of strategies and mechanisms for their implementation, analysis of learning and its effectiveness at different levels, conscious correction, use of reflective learning abilities, etc. The most effective study of the characteristics of reflexive abilities to self-regulation and students' skills is possible through the use of a complex of psychodiagnostic tools aimed at studying such variables, which, on the one hand, will act as determinants of personal selfregulation, and on the other - features that determine the levels of developmental levels of developmental levels. to selfregulation and students' skills as subjects of cognitive learning.

\section{Theoretical background}

Cognitive activity of students in selfregulated learning is considered in the world of psychological science as a factor of effectiveness of educational activity.
Cognitive abilities to self-regulated learning, its corresponding motivation develops in the process of educational activities (Zimmerman, 2011). Underdevelopment cognitive processes in intellectual and educational student activity does not allow them to effectively manage their own mental processes, and therefore, reduces the effectiveness of learning (Schunk \& Greene, 2018).

Studies of reflection and its connection with cognitive and metacognitive aspects of educational activity occupy an important place in the modern world of psychological science, because it is the reflexive abilities that is a kind of metacognitive mechanism that regulates students' educational and intellectual activity and directly influences personality. (Andrade \& Brown, 2016). Acquiring knowledge to improve learning requires sufficient cognitive development of students' self-regulated learning (Zimmerman \& Kitsantas, 2006). Students need to be regulated to overcome the learning difficulties their metacognitive processes. Actually, conscious use of their cognitive strategies makes students more autonomous and self-determined in overcoming difficulties (Cleary \& Kitsantas, 2017).

Among modern domestic scientists who have studied the problem of reflexivity, reflexive skills and of cognitive aspects of students' self-regulated learning, the works of I. Pasichnik and S. Maksimenko (cognitive-style features of personality) should be distinguished in educational activity) (Pasichnyk and Maksimenko, 2010), O. Savchenko (Reflexive Competence in Learning) (Savchenko, 2016), A. Ravchyna (Cognitive Strategies and Reflection in Learning) (Ravchina, 2015), 
"SOCIALIZATION \& HUMAN DEVELOPMENT" INTERNATIONAL JOURNAL

T. Khomulenko and T. Dotsevych (Metacognitive Processes of Personality, meta-memory in training) (Khomulenko and Dotsevich, 2014), V. Kalamazh (reflexivity and metacognition in students' project activity), O. Penkova (value aspects of self-regulation) (Penkova, 2016), M. Teslenko and N. Yudina (self-regulation of educational activity) (Teslenko and Yudina, 2018) and others.

The analysis of scientific works has allowed us to state that cognitive processes and reflexivity are important regulatory mechanisms of students' educational activity at the individual-personal and cognitive levels respectively. The results of the theoretical analysis indicated the need to study students 'reflective skills at the cognitive level, and this allowed us to develop a methodological scheme for further empirical study of the features of students' reflective ability to self-regulate and skills (Balashov, 2019).

\section{Purpose and methodology}

The purpose of our study is theoretical analysis and empirical study of levels of students' self-regulation ability and cognitive skills. The achievement of this goal led to the following tasks: to analyze and summarize existing approaches to the problems of studying self-regulation abilities and students 'skills at cognitive level and to empirically investigate the features of levels of self-regulation abilities and students' skills at cognitive level.

Research methods: theoretical and methodological analysis of categoricalconceptual field of problems; critical analysis and comparison of major aspects of students' reflective abilities to selfregulate and reflective skills at cognitive level; theoretical synthesis of components of students' reflective abilities to selfregulation and reflexive skills at cognitive level; empirical detection with the help of a certain diagnostic toolkit of reflexive abilities for self-regulation and reflexive skills of students at cognitive level.

An empirical study was conducted at the faculty of psychology at Taras Shevchenko National University of Kyiv. In order to determine the levels of selfregulation ability and students' skills at the cognitive level, a sample of 35 students in the age range of 17 to 21 years was formed $(\mathrm{M}$ age $=20.83, \mathrm{SD}=1.73)$. To determine the importance for students of developing reflexive self-regulation abilities we used the Capability Task Scale to self-regulation "from the methodology" Life tasks for selfdevelopment "developed by O. Savchenko and Y. Domanova. The group of life tasks identified in this scale is specified in statements that reflect life's tasks for the development of abilities to manage various forms of one's own activity, restore their resources and control psychological states (Savchenko, 2016: 167).

The subjects evaluated the statements on a 4-point scale for the degree of relevance: 0 points - absolutely not relevant; 1 point - practically not actual; 2 points - relevant to some extent; 3 points very relevant. We used the following indicators: the total indicator of the significance of the tasks for the development of self-regulation abilities in the present (calculated as the sum of the estimates obtained on the scale of assessment of current tasks in the current time);

the total indicator of the significance of the tasks for the development of selfregulatory abilities in the near future (calculated as the sum of the estimates obtained on the scale of assessment of life tasks for the short term); 
"SOCIALIZATION \& HUMAN DEVELOPMENT" INTERNATIONAL JOURNAL

average indicators of the importance of the tasks for the development of the ability to self-regulation in the present;

the average of the significance of the tasks to develop the ability to selfregulation in the short term.

\section{Results}

The results obtained show that according to the Self-Regulation Task Scale, $41.30 \%$ of participants had a low level of actualization of current selfregulatory tasks, $54.35 \%$ had an average level, and only $4.35 \%$ had a high level. The results are presented at the Figure 1.



Fig. 1. Indicators of the level of actualization of tasks for self-regulation in the present time, $\%$.

For a group of subjects with a generally high level of actualization on the scale of "self-regulation", the assessment of most of the reflexive abilities included in the structure of this scale is currently at a high level. This means that such students are aware of the dependence of future casework on the level of skill development to quickly mobilize resources, rebuild them in the short term, spend economically in problem-solving situations and in complex activities. Analyzing one's mental states while taking action today, rethinking the means used to solve problems, and probable events is an important reason for setting the task of developing behavioral self-regulation skills in the near future (Savchenko, 2016: 186).

According to O. Savchenko, "the researchers who get high scores on this factor tend to stimulate their own activity, to adequately assess the situation and their ability to control its course. Such persons consciously approach their own criteria for evaluating the success of their activity, they try to develop their ability to be aware of and control emotions and actions, to rationally treat their own resources, to economically spend them in stressful situations, and to quickly recover for further activity"(Savchenko, 2016). 167).

For the group of subjects with a generally low level of actualization on the "self-regulation" scale, the evaluation of all the reflexive abilities within the structure of this scale is quite low at present. Thus, it can be concluded that those with low levels of self-regulation ability are not currently willing to spend the time and effort to develop their own control and regulation skills, as they do not feel consciously aware of the subject control events. Passive attitude to the problem solving process and low level of awareness to their actions and strategies: factors that prevent them from feeling their ability to control their emotions and actions, to form a view of themselves as an object that can be 
"SOCIALIZATION \& HUMAN DEVELOPMENT" INTERNATIONAL JOURNAL

consciously managed (Savchenko, 2016: 186).

Table 1 presents in more detail the data obtained on the Scale for the Development of Self-Regulation. The data in Table 1 indicate that the level of $+6,2$ ).

Table 1. Data on the scale "Tasks for the development of self-regulation" (methodology "Life tasks for self-development" O. Savchenko, Ya. Domanova)

\begin{tabular}{|l|l|l|l|}
\hline № & Life's tasks & $\begin{array}{l}\text { Average in } \\
\text { the present }\end{array}$ & $\begin{array}{l}\text { Average in } \\
\text { the closest } \\
\text { future }\end{array}$ \\
\hline 1 & $\begin{array}{l}\text { Learn the techniques of stimulating your activity } \\
\text { (self-praise, self-support, self-punishment, etc.) }\end{array}$ & 1.70 & 1.65 \\
\hline 7 & $\begin{array}{l}\text { Learn how to quickly assess the situation, your condition, } \\
\text { to carry them for the purpose of activity }\end{array}$ & 1.96 & 1,57 \\
\hline 10 & $\begin{array}{l}\text { Establish your own criteria and standards that will } \\
\text { adequately assess the success of your business }\end{array}$ & 1,78 & 1,57 \\
\hline 15 & $\begin{array}{l}\text { Develop the ability to be aware of your emotions, use them } \\
\text { as clues in difficult situations }\end{array}$ & 2,11 & 1,65 \\
\hline 19 & $\begin{array}{l}\text { To develop the ability to rationally control their resources, } \\
\text { to spend them economically in a state of stress, high stress }\end{array}$ & 2 & 1,76 \\
\hline 22 & $\begin{array}{l}\text { Identify ways and techniques to quickly recover your } \\
\text { strengths and resources }\end{array}$ & 2,09 & 1,46 \\
\hline 26 & $\begin{array}{l}\text { Learn to control your emotions, actions, adjust the pace and } \\
\text { timing of things without delaying them until the last moment }\end{array}$ & 2,02 & 1,63 \\
\hline & The average value & 1,95 & 11,42 \\
\hline & The average total value on a scale & 13,66 & \\
\hline
\end{tabular}

Among the reflective abilities of both present and future, the most important is the ability to "understand their emotions, use them as clues in difficult situations" (2.11 points - present; 1.76 - future), the ability to "identify ways and techniques of the fast restoration of their forces and resources "(2.09 points - present; 1.76 future), developed the ability to" rationally control their resources, economically spend them in a state of stress, increased load "(2 points - present; 1.65 - future). At the same time, on average, there is a sharp decrease in the relevance of the ability to "control their emotions, actions, adjust the pace and timing of cases without delaying them until the last moment" (2.02 points - present time; 1.46 - the future). High importance of significance of self-regulatory tasks localized at the current time interval $(\mathrm{M}=$ $13.66+5.1)$ outweighs the level of significance of self-regulatory tasks localized in the near future $(\mathrm{M}=11.41$ 
"SOCIALIZATION \& HUMAN DEVELOPMENT" INTERNATIONAL JOURNAL

surveyed, the task to learn how to quickly assess the situation, their condition, to correlate them with the purpose of activity is relevant to varying degrees $(56.5 \%$ relevant to the average, for $19.6 \%$ - very relevant), for $23,9 \%$ is practically irrelevant. The task is to formulate own criteria and standards that will adequately evaluate the success of their activities for
$69.5 \%$ of the respondents relevant to different extent (for $47.8 \%$ relevant on average, for $21.7 \%$ - very relevant), for $17.4 \%$ - practically irrelevant, and only for $13.1 \%$ - absolutely out of date. (self-praise, self-support, self-punishment, etc.)

In general, the results are presented in Table 2.

Table 2. Percentage distribution of data on the scale "Tasks for the development of selfregulation" in the present time (the methodology "Life tasks for self-development"

O. Savchenko, J. Domanova).

\begin{tabular}{|c|c|c|c|c|c|}
\hline № & Life's tasks & $\begin{array}{l}\text { Absolutely } \\
\text { not relevant } \\
\%\end{array}$ & $\begin{array}{l}\text { Practically } \\
\text { not relevant } \\
\%\end{array}$ & $\begin{array}{l}\text { Relevant to } \\
\text { some extent } \\
\%\end{array}$ & $\begin{array}{l}\text { Very } \\
\text { relevant } \\
\%\end{array}$ \\
\hline 1 & $\begin{array}{l}\text { Learn the techniques of } \\
\text { stimulating your activity } \\
\text { (self-praise, self-support, self- } \\
\text { punishment, etc.) }\end{array}$ & 10,9 & 26,1 & 45,7 & 17,4 \\
\hline 7 & $\begin{array}{l}\text { Learn how to quickly assess the } \\
\text { situation, your condition, } \\
\text { to carry them for the purpose of } \\
\text { activity }\end{array}$ & 0 & 23,9 & 56,5 & 19,6 \\
\hline 10 & $\begin{array}{l}\text { Establish your own criteria and } \\
\text { standards that will adequately } \\
\text { assess the success of your business }\end{array}$ & 13 & 17,4 & 47,8 & 21,7 \\
\hline 15 & $\begin{array}{l}\text { Develop the ability to be aware of } \\
\text { your emotions, use them as clues } \\
\text { in difficult situations }\end{array}$ & 2,2 & 13 & 56,5 & 28,3 \\
\hline 19 & $\begin{array}{l}\text { To develop the ability to rationally } \\
\text { control their resources, to spend } \\
\text { them economically in a state of } \\
\text { stress, high stress }\end{array}$ & 4,3 & 23,9 & 39,1 & 37 \\
\hline 22 & $\begin{array}{l}\text { Identify ways and techniques to } \\
\text { quickly recover your strengths and } \\
\text { resources }\end{array}$ & 4,3 & 19,6 & 39,1 & 37 \\
\hline 26 & $\begin{array}{l}\text { Learn to control your emotions, } \\
\text { actions, adjust the pace and timing } \\
\text { of things without delaying them } \\
\text { until the last moment }\end{array}$ & 6,5 & 13 & 52,2 & 28,3 \\
\hline & The average value & 5,9 & 19,6 & 48,1 & 26,4 \\
\hline
\end{tabular}

Using them we can conclude that the task is relevant for the largest proportion of respondents "To develop the ability to be aware of their emotions, to use them as clues in difficult situations" (56.5\% - actual on average, $28.3 \%$ - very actual) and "Learn to control their emotions, actions, regulate the pace and timing of cases, not tightening them to the last moment " $(52.2 \%$ - topical on average, $28.3 \%$ - very topical). 
Also significant is the proportion of persons for whom the task is "Learn to quickly assess the situation, their condition, relate them to the purpose of activity" $(56.5 \%$ - very average, $19.6 \%$ - very relevant). According to O. Savchenko, "high responsibility, a tendency to accumulate internal tension, not the formation of mechanisms of involuntary control of their emotions and actions during the defeat - factors which awareness causes the increased level of significance for the subject of tasks for the development of abilities to self-regulation" ( Savchenko, 2016: 168). The high importance of life tasks for the development of self-regulation in the current period of life is associated with high activity of the subject, his willingness to solve problems and overcome difficulties through the use of rational techniques and volitional efforts (Savchenko, 2016: 168). Thus, in the study group of students, the vital task of developing self-regulation skills becomes relevant, since students are first of all aware of the need to develop and practice their skills, to use them as clues in difficult situations, control their emotions, actions, adjust the pace and timing of cases without delaying them until the last moment, quickly assess the situation, their condition, relate them to the purpose of the activity, as well as determine ways and methods of rapid recovery of their strength and resources.

Diagnostic results of the study group by the method "Reflexive skills (cognitive level)" O. Savchenko made it possible to conclude that in the study group is dominated by the average level of overall development of reflexive cognitive skills.

Below we present an analysis of the results on separate scales of the methodology. The scale "Ability to explain to yourself and others the course of your thinking, the reasons for choosing a certain way to decide strategies" in its structure integrates techniques for the effective application of the elect means of solving the problem, namely: to be aware of the selected intellectual means used to solve the reflexive task; flexible transition from the reflective plane to the plane of action, using the chosen tool in practice; describe the results of their own reflexive acts, reflective experiences; explain the appropriateness of the selected remedy; quickly evaluate options for the solution internally (Savchenko, 2016: 65-66). The higher the level of development of skills to understand and explain to themselves the reasons for choosing a certain solution, strategies, the more formed is the individual style of volitional selfregulation, which is primarily manifested in the ability to modeling of forms of own activity taking into account internal and external conditions and a high level of flexibility. It was found that in the study group, the average level of development of reflexive skills prevails to explain to themselves and others the course of their reasoning, the reasons for choosing a certain solution, strategies.

The scale "The ability to be aware of your own emotional experience, control their course, support feeling of confidence "describes the techniques that are responsible for the awareness and analysis of emotional experiences, for controlling their course. Increasing the level of development of this skill prevents situations that lead to the development of depressive states. The core of this skill is formed not by self-regulation skills, but by cognitive processes of awareness, comparison, isolation of essential features and behavioral attitudes to quickly switch 
"SOCIALIZATION \& HUMAN DEVELOPMENT" INTERNATIONAL JOURNAL

attention, to ignore complications and failures due to easy, irresponsible attitude to certain aspects of one's life (Savchenko, 2016): 68 .

It was found that in the study group, the average level of development of reflexive skills is to be aware of their own emotional experiences, to control their course, to maintain a sense of confidence. From the presented data we can conclude that the biggest problems on this scale students feel with the ability to navigate intuitive guesses in the form of emotional feelings $(\mathrm{Xm}=2.77$ points $)$, to consider many factors and circumstances when evaluating their success $(\mathrm{Xm}=3.16$ points), to make metacognitive judgments ("when I get acquainted with the conditions of the task, I have a feeling of confidence (or uncertainty) that I can" - Xm $=3.19$ points).

The scale "Ability to keep yourself in the plane reflective reflections, analyze the reasons for one's own actions, causes of failures »describes the ability to keep oneself in the plane of reflection. The core of this group of skills were techniques aimed at selecting the most appropriate means of solving the problem. Researchers with a high level of development of these skills feel active subjects of their own life, they understand that they can control their own behavior, control strong emotional manifestations that may prevent them from realizing their intentions and goals. They easily solve the problems of meaningmaking, giving meaning to their own actions and desires, which allows them to experience inner freedom, to enjoy the pleasure of manifestations of their own activity. Reflective skill developed enhances the personal capacity of the subject it does his more confident in his own ability to overcome difficult life situations, solve difficult tasks (Savchenko, 2016: 68). It is established that in the studied the group is dominated by the average level of development of reflexive skills to keep themselves in the plane of reflective reflections, to analyze the reasons for their own actions, the causes of failures. From the presented data we can conclude that the biggest problems on this scale students feel with the ability to slow down impulsive decisions, additionally weigh and think, even if there is an idea about the solution of the problem $(\mathrm{Xm}=$ 3.48 points), the ability to analyze the causes of error during failure $(\mathrm{Xm}=3.52$ points), ability to understand the source and cause of a new assumption while solving the problem $(\mathrm{Xm}=3.52$ points $)$.

\section{Discussion}

The process of conducting our research was divided into theoretical and methodological analysis of categoricalconceptual field of problems; critical analysis and comparison of major aspects of students' reflective abilities to selfregulate and reflective skills at cognitive level; theoretical synthesis of components of students' reflective abilities to selfregulation and reflexive skills at cognitive level; empirical detection with the help of a certain diagnostic toolkit of reflexive abilities for self-regulation and reflexive skills of students at cognitive level.

In this approach, in our opinion, the uniqueness of this study is quite high in comparison with the researches already existing (Andrade, \& Brown, 2016; Ravchyna, 2015; Teslenko, \& Yudina, 2018).

The study was conducted in several stages. At the organizational stage, theoretical information concerning the issue of cultural styles and well-being factors for different ethnic groups was 
"SOCIALIZATION \& HUMAN DEVELOPMENT" INTERNATIONAL JOURNAL

elaborated. In the second stage, empirical research was conducted using standardized techniques. The next stage was the processing and interpretation of the results.

In addition, there are limitations to the results obtained. Thus, the study hypothesis was tested only on young representatives of the country population from the students' environment. However, it is also promising to study the situation in the society in general. This study opens up the potential for further scientific research and highlights the relevance of the chosen direction of scientific research.

\section{Conclusion}

To determine the importance for students of the development of reflexive abilities to self-regulation, we used the scale "Tasks for the development of selfregulation abilities" from the methodology "Life tasks for self-development", developed by O. Savchenko and Ya. Domanova, by which we determined the indicators of the level of actualization of students' tasks regulation. currently on the appropriate scales. In general, the results suggest that the task of "Developing the ability to be aware of their emotions, using them as clues in difficult situations", "Learning to control their emotions, actions, adjusting the pace and timing of cases without delaying them, is quite relevant for the largest number of respondents. until the last moment "and" Learn to quickly assess the situation, your condition, relate them to the purpose of the activity ". Using the method of O. Savchenko "Reflexive skills (cognitive level)" (Table 3) we defined generalized indicators of the average values of reflexive skills of the cognitive level on such scales as "Ability to explain to yourself and others the course of their reasoning, reasons for choosing a certain solution, strategies emotional experiences, controlling their course, maintaining a sense of confidence ", "Maintaining yourself in the plane of reflective reflections, analyzing the reasons for your own actions, causes of failures", "Ability to organize your work with seeking a solution to verify their assumptions", "Ability to carry out the evaluation of the results according to various criteria, formulate valuejudgments", "The ability to understand various aspects of processes to find solutions, cognitive, emotional, behavioral, and the general level of cognitive abilities reflective level". From the obtained data we can conclude that students have the lowest scores on their reflexive cognitive skills on the scale "Ability to evaluate results by different criteria, formulate judgmental judgments". The overall level of reflexive development of students' cognitive level is average.

Table 3. Data on the scale "Tasks for the development of self-regulation" (methodology "Life tasks for self-development" O. Savchenko, Ya. Domanova)

\begin{tabular}{|l|l|l|l|}
\hline No & Scale & $\begin{array}{l}\text { Average } \\
\text { point }\end{array}$ & Level \\
\hline 1 & $\begin{array}{l}\text { Ability to explain to yourself and others the course of your } \\
\text { reasoning, the reasons for choosing a certain } \\
\text { solutions, strategies }\end{array}$ & 23,32 & Medium \\
\hline 2 & $\begin{array}{l}\text { Ability to be aware of one's own emotional experiences, to } \\
\text { control their course, to maintain a sense of confidence }\end{array}$ & 24,44 & Medium \\
\hline 3 & $\begin{array}{l}\text { Keep yourself in the plane of reflective thinking, analyze the } \\
\text { reasons for your own actions, the causes of failures }\end{array}$ & 26,22 & Medium \\
\hline
\end{tabular}


"SOCIALIZATION \& HUMAN DEVELOPMENT" INTERNATIONAL JOURNAL

\begin{tabular}{|l|l|l|l|}
\hline 4 & $\begin{array}{l}\text { Ability to streamline the process of finding a solution, to } \\
\text { verify their assumptions }\end{array}$ & 18,7 & Medium \\
\hline 5 & $\begin{array}{l}\text { Ability to evaluate results by different criteria, formulate } \\
\text { judgment judgments }\end{array}$ & 21,1 & Medium \\
\hline 6 & $\begin{array}{l}\text { Ability to be aware of various aspects of the decision- } \\
\text { making process: cognitive, emotional, behavioral }\end{array}$ & 21,88 & Medium \\
\hline 7 & $\begin{array}{l}\text { The general level of development of reflexive cognitive } \\
\text { skills }\end{array}$ & 135,66 & Medium \\
\hline
\end{tabular}

The prospect of further research is seen in the detailed study of the development of components of psychological self-regulation of students' educational activity in the process of metacognitive monitoring, as well as the students' reflective skills as regulatory mechanisms of students' educational activity at the personal level.

\section{Conflict of interests}

There is no real conflict of interests at the time of writing this article or potential conflicts of interest for authors with responsible persons or any other person third parties on the subject matter of the article and related areas of legal research.

Acknowledgments. The study did not receive a grant from any financial agency in state, commercials or the nonprofit sector.

\section{References}

Andrade, H. \& Brown, G. (2016). Student Self-Assessment in the Class-room, in Gavin T. L. Brown, Lois R. Harris (Eds.), Handbook of Human and Social Conditions in Assessment ( $p$. 319-334). New York: Routledge.

Balashov, E., Pasichnyk, I., Kalamazh, R., Dovhaliuk, T. \& Cicognani, E. (2018). Psychological, Emotional and Social Wellbeing and Volunteering: A Study on Italian and Ukrainian University Students. Youth Voice Journal,18, 1-22.
Cleary, T. J. \& Kitsantas, A. (2017). Motivation and Self-Regulated Learning Influences on Middle School Mathematics Achievement. School Psychology Review, Vol. 46, No. 1, 88-107.

Khomulenko, T. B. \& Dotsevych T. I. (2014). Metapamiat: naukovi pidkhody ta eksperymentalnointrospektyvna metodyka doslidzhennia [Metamemory: Scientific Approaches and Experimental-Introspective Methodology of Research]. Bulletin of $\mathrm{H}$. Skovoroda Kharkiv National Pedagogical University. Series "Psychology", \#49, 193-211 [in Ukrainian].

Pasichnyk, I. D. \& Maksymenko S. D. (2010). Role of Cognitive and Style Peculiarities of Personality in the Process of Learning Activity [Rol kohnityvnyn-styliovykh

osoblyvostej osobystosti v protsesi navchalnoji dijalnosti]. Scientific Notes of National University of Ostroh Academy. Series "Psychology and Peda-gogy", 14, 3 10 [in Ukrainian].

Penkova, O. I. (2016). Problem of SelfRegulation of Personality: Value Aspect [Problema samorehuliatsiji osobystosti: tsinnisnyj aspekt]. Scientific Bulletin of Kherson State University. Series "Psychological 
"SOCIALIZATION \& HUMAN DEVELOPMENT" INTERNATIONAL JOURNAL

Sciences", 2(1), 114-118 [in Ukrainian].

Ravchyna, T. I. (2015). Theoretical and Methodological Aspects of Organization of Learning Process of Students of Higher School in Context of Theory of Constructivism [Teoretyko-metodychni aspekty orhanizatsiji protsesu navchannia studentiv vyshchoji shkoly v konteksti teoriji konstruktyvizmu]. Ukrainian Peda-gogical Journal, 4, 129-136 [in Ukrainian].

Savchenko, O. V. (2016). Reflexive competence: Methods and Procedures of Diagnostics [Refleksyvna kompetentnist: Metody i protsedury otsinky], Kherson: PP Vyshemyrskyi V.S. [in Ukrainian].

Schunk, D. H., \& Greene, J. A. (2018). Historical, contemporary, and future perspectives on self-regulated learning and performance, in D. H. Schunk \& J. A. Greene (Eds.), Educational psychology handbook series. Handbook of self-regulation of learning and performance (p. 115). Routledge/Taylor \& Francis Group.

Teslenko, M. M. \& Yudina, N. O. (2018). Psychological Peculiarities of Personality of Self-Regulation of Learning and Professional Activity of Students [Psykholohichni osoblyvosti samore-huliatsiji navchalno-profesijnoji dijalnosti studentiv]. Psycholo-gy and Personality, 1(13), 118-127 [in Ukrainian].

Zimmerman, B. (2011), Motivational sources and outcomes of selfregulated learning and performance, in B. Zimmerman and D. Schunk, (eds), Handbook of Self-Regulation of Learning and Performance, Abingdon: Routledge, 49-64.

Zimmerman, B. J. \& Kitsantas, A. (2006), A writer's discipline: the development of selfregulatory skill, in S. Hidi and P. Boscolo, (eds), Writing and Motivation, Amsterdam: Kluwer, 51-69. 
"SOCIALIZATION \& HUMAN DEVELOPMENT" INTERNATIONAL JOURNAL

\title{
DIFFERENCES IN PROFESSIONAL RESPONSIBILITY FOR STATUS AND ROLE IN THE WORKPLACE
}

https://doi.org/00.00000/SHDISJ-00-0.0-0000

Sadova M.A. https://orcid.org/0000-0002-4297-7317

Podshyvalkina V.I. https://orcid.org/0000-0003-2828-5928

\begin{abstract}
The purpose of the study is to empirically substantiate the status and role differences in professional responsibility in the workplace. Methods: theoretical, empirical, mathematical statistics. Research results are based on the use of mathematical and statistical procedures, differences in the professional responsibility of workers with different status-role positions in the workplace are substantiated. These differences indicate, according to the authors, that leadership positions require greater responsibility, in contrast to the positions of subordinate personnel, since the head has the responsibility to regulate, control, organize, motivate, delegate the authority and activities of subordinates. It is shown that in comparison with subordinates, managers have a greater level of personal resources, a balance of their life achievements and failures, a higher adaptive potential and less stress vulnerability.

The presented results showed that among subordinates, but especially among managers, professional responsibility is most clearly manifested at the cognitive and behavioral levels, and to a lesser extent at the affective, emotional level.

In addition, it has been shown that managers are characterized by a significantly greater variety of socially determined career incentives, in particular, orientation to professional competence, management, autonomy, challenge, and entrepreneurship. Subordinates are more inclined to consider their work as service and are focused on the integration of various areas of their lives and on self-realization on this basis.

The results obtained suggest that the personal foundations of the subject of responsibility discovered by the authors, on the one hand, show the degree of "rooted" responsibility as a personality trait, and on the other hand, they are the most important mechanisms for the implementation of responsible human behavior in the workplace.
\end{abstract}

Keywords: professional responsibility, status-role position, ordinary employee, manager.

\section{Introduction}

The relevance of the study is due to the fact that numerous production problems in Ukraine, to some extent, are not solved due to the unfortunately widespread professional irresponsibility. Perhaps the most painful problem of today is the crisis of responsibility that permeates all structures and levels of the social organism. Irresponsible attitude of man to other people, society in general, the future of the country, the environment reaches a critical point.

The modern specialist pursues first of all his own local goals and does not want to be responsible for the consequences of his 
"SOCIALIZATION \& HUMAN DEVELOPMENT" INTERNATIONAL JOURNAL

professional activity, and even more so to take responsibility for others. Irresponsibility of employees of organizations, both management and subordinates is manifested in the long run, that is, past irresponsible actions can lead to inevitable disasters in the future.

The development of a subjective approach in psychology allows us to pay attention to the role of responsibility, in particular professional, in the development of personality. At the same time, the study of external contexts of professional activity, first of all, norms and rules of activity as conditions for freedom of choice and action in appropriate situations and formation of personal, "author's" position in relation to one's professional life acquire special significance.

The purpose of the study is to empirically substantiate the differences in the professional responsibility of specialists in terms of status and role position in the workplace.

\section{Theoretical foundations of the study}

Scientific study of this phenomenon in foreign psychology is based on a humanistic approach that explores professional responsibility: a) from a sociopsychological standpoint (W. Davis, B. Ageev, S. Anisipov, S. Buhler, M. Bakhtin, S. Baranova, O Bodalov, M. Boryshevsky, A. Brushlinsky) (Davis, 2017); b) from the standpoint of moral development of personality (E. Phares, F. Pearl, J. Piaget, L. Kohlberg, X. Heckhausen) (Phares, 1976); c) from the standpoint of personal freedom (K. Helkama, S. Kierkegaard, L. May, J. Sartre, W. Frankl, K. Jaspers) (Helkama, 2010).

In the attributive approach, responsibility and locus of control are often interpreted as synonymous concepts ( $\mathrm{J}$.
Rotter, W. Atkinson, J. Conor-Smith, D. Mcclelland, L. Murphy, R. Moss, R. Lazarus, S. Rosenzweig, J. Rotter , N. Hahn, A. Thomsen, G. Whitkin, A. Wadsworth, F. Freidenberg, S. Folkman, S. Schwartz, J. Schaefer) (Rotter, 1966).

The problem of responsibility in the psychotherapeutic approach is analyzed as a condition for the provision of psychological assistance (F. Collins, A. Bandura, O. Vepsheg, J. Sartre, W. Frankl, Z. Freud, I. Yalom) (Collins, 2013).

In the psychological and pedagogical approach the problem of education of responsibility at different age stages of formation of the person is investigated - it is a question of conditions, factors, receptions influencing education of this quality (L. Berkovitz, E. Phares, L. Slavin, V. Gorbachev, Z. Borisova, J. Zavadskaya, L. Shevchenko, I. Bekh, T. Morozkina, N. Rumyantseva, V. Semichenko) (Berkovitz, 1968).

The personal-situational approach considers professional responsibility from the standpoint of personal and situational determinants (S. Rubinstein, K. Abulkhanova-Slavska, B. Lomov, E. Klimov, J. Zavadska and L. Shevchenko) (Sadova, 2018).

The problem of professional responsibility was dealt with by Ukrainian scientists who classified a number of areas of professional responsibility research (J. Ladd, G. Lozhkin, O. Lozorko, I. Sagan, V. Pryadein, L. Dementiy, M. Koinov) (Ladd, 2015).

Unlike the above authors, our subjectcontext concept is the result of analysis and generalization of views of domestic and foreign scholars on the problem of responsibility and the author's understanding of the essence of professional responsibility in terms of 
"SOCIALIZATION \& HUMAN DEVELOPMENT" INTERNATIONAL JOURNAL

subject, object, subjectivity and context. The subject-context concept of professional responsibility allowed to identify the appropriate typology of professional responsibility of the individual, its relationship with personal and situational determinants, to make a psychological analysis of safety, risks and personal resources in the professional sphere of personal life relevant to the content of responsibility.

\section{Methods}

Subject sampling: the authors studied middle and senior managers and ordinal employees in a ratio of 1 leader to 4 subordinates. The number of people who participated in the study: leaders - 106, and subordinates - 316 people.

Methods used in the study: empirical questionnaires "Diagnosis of the level of responsibility" S. Rudenko; E. Stein's "Anchor Careers", N. Vodopyanov's "Losses and Gains of Personal Resources", M. Stein's "Level of Subjective Control" (J.C.); R. Kettell's 16-factor questionnaire; standardized interview "Components of professional responsibility" by L. Dementiy; and methods of mathematical statistics - calculations by F-test and Student's t-test.

Research procedure. Our research was conducted in several stages: an empirical research program was developed, aimed at identifying the professional responsibility of the employees of management positions and subordinates; psychodiagnostic methods were introduced, which made it possible to determine the level of responsibility of the relevant level of employees; was performed statistical data processing using the computer program SPSS 20.0 for Windows; were substantiated the results of the study.

\section{Results}

We will carry out a detailed comparative analysis of the results of tests, whuch were used for the two statuses "managers" and "subordinates".

Table 1 shows the differences between socially conditioned motivations (values, social attitudes, interests) by status and role positions (according to the questionnaire "Career Anchors". Author: E. Shane).

Analyzing the results of the table, it should be noted that significant differences in the corresponding questionnaire were found on all scales, which indicates the credibility of the results of the study. Let's analyze each of the scales of the "Career Anchor" questionnaire.

Practically at the one percent level of bilateral significance $(p \leq 0.01)$ according to the Student's $t$ test, differences were revealed between managers and subordinates in all career settings, namely on professional competence, management, autonomy, service, challenge, integration. lifestyles, for entrepreneurship.

Table 1. Differences of socially conditioned motivations to activity (value orientations, social attitudes, interests) according to the status and role positions of employees

\begin{tabular}{|c|c|c|c|c|c|c|c|c|}
\hline $\begin{array}{c}\text { Socially } \\
\text { conditioned } \\
\text { motivations for } \\
\text { activity }\end{array}$ & $\begin{array}{c}\text { Status-role } \\
\text { position at } \\
\text { work }\end{array}$ & $\mathbf{N}$ & $\begin{array}{c}\text { Avera } \\
\text { ge }\end{array}$ & $\begin{array}{c}\text { Std. } \\
\text { deviation }\end{array}$ & $\mathbf{F}$ & $\begin{array}{c}\text { Significa } \\
\text { nce for F }\end{array}$ & $\mathbf{T}$ & $\begin{array}{c}\text { Significance } \\
\text { (2) for t }\end{array}$ \\
\hline $\begin{array}{l}\text { 1. Professionacomp } \\
\text { etence }\end{array}$ & $\begin{array}{c}\text { Managemen } \\
\text { t position }\end{array}$ & 106 & 8,0066 & 1,45034 & 6,586 &, $011^{* *}$ & 12,21 &, $000^{* * *}$ \\
\cline { 2 - 9 } & $\begin{array}{c}\text { Ordinary } \\
\text { employee }\end{array}$ & 316 & 5,8180 & 1,64238 & & & 12,99 &, $000^{* * *}$ \\
\hline
\end{tabular}


"SOCIALIZATION \& HUMAN DEVELOPMENT" INTERNATIONAL JOURNAL

\begin{tabular}{|c|c|c|c|c|c|c|c|c|}
\hline \multirow[t]{2}{*}{ 2. Management } & $\begin{array}{c}\text { Managemen } \\
\text { t position }\end{array}$ & 106 & 7,6123 & 1,64639 & 6,066 &, $014 * *$ & 20,84 &, $000 * * *$ \\
\hline & $\begin{array}{l}\text { Ordinary } \\
\text { employee }\end{array}$ & 316 & 4,1563 & 1,41583 & & & 19,34 &, $000 * * *$ \\
\hline \multirow[t]{2}{*}{ 3. Autonomy } & $\begin{array}{c}\text { Managemen } \\
\text { t position }\end{array}$ & 106 & 7,1047 & 1,54120 &, 811 &, 368 & 10,91 &, $000 * * *$ \\
\hline & $\begin{array}{l}\text { Ordinary } \\
\text { employee }\end{array}$ & 316 & 5,2297 & 1,52711 & & & 10,86 &, $000 * * *$ \\
\hline \multirow[t]{2}{*}{ 4. Service } & $\begin{array}{c}\text { Managemen } \\
\text { t position }\end{array}$ & 106 & 7,2775 & 1,32412 & 3,749 &, $054^{*}$ & 6,554 &, $000 * * *$ \\
\hline & $\begin{array}{l}\text { Ordinary } \\
\text { employee }\end{array}$ & 316 & 8,3594 & 1,51652 & & & 7,010 &, $000 * * *$ \\
\hline \multirow[t]{2}{*}{ 5. Challenge } & $\begin{array}{c}\text { Managemen } \\
\text { t position }\end{array}$ & 106 & 6,4774 & 1,54021 &, 063 &, 802 & 11,92 &, $000 * * *$ \\
\hline & $\begin{array}{l}\text { Ordinary } \\
\text { employee }\end{array}$ & 316 & 4,3601 & 1,59479 & & & 12,13 &, $000 * * *$ \\
\hline \multirow[t]{2}{*}{$\begin{array}{l}\text { 6. Integration of } \\
\text { lifestyles }\end{array}$} & $\begin{array}{c}\text { Managemen } \\
\mathrm{t} \text { position }\end{array}$ & 106 & 6,1829 & 1,23011 &, 513 &, 474 & 7,108 &, $000 * * *$ \\
\hline & $\begin{array}{l}\text { Ordinary } \\
\text { employee }\end{array}$ & 316 & 7,1302 & 1,17261 & & & 6,941 &, $000 * * *$ \\
\hline \multirow[t]{2}{*}{$\begin{array}{l}\text { 7.Entrepreneurshi } \\
\mathrm{p}\end{array}$} & $\begin{array}{c}\text { Managemen } \\
\text { t position }\end{array}$ & 106 & 3,6849 & 2,51198 & 18,91 & $\begin{array}{l}, 000 \\
* * *\end{array}$ & 2,503 &, $000 * * *$ \\
\hline & $\begin{array}{l}\text { Ordinary } \\
\text { employee }\end{array}$ & 316 & 3,1041 & 1,89595 & & & 2,181 &, $000 * * *$ \\
\hline
\end{tabular}

According to F-test, at one percent significance level $(\mathrm{p} \leq 0.01)$, the differences between the two groups of subjects were confirmed by such settings as the attitude to entrepreneurship and the stability of the workplace. Also by F-test, at a five percent level of significance $(\mathrm{p} \leq$ $0.05)$ were found differences in attitudes to professional competence, management, autonomy, stability of residence. In addition, according to $\mathrm{F}$-test at a ten percent level of significance (p була 0.1) was confirmed as a trend difference in attitude to the ministry.

Let's analyze the results on scales, the significant differences between officials and subordinates are confirmed by the criteria of Student's t-test and F-test,.

According to these two criteria, the focus on professional competence is more typical for managers (8.01) than for subordinates (5.82), which is associated with their decision-making and delegation of these powers. The same applies to the installation of management. It is higher in managers (7.61) than in subordinates (4.16). For the position of manager, the attitude to management and the corresponding qualities are the key to their effective work.

Leaders (7.11) are more focused than subordinates (5.23) and on autonomy. Most likely, this is due to the need for the leader to make independent decisions, to look for adequate ways to solve problems.

In addition, career orientation as a challenge is more common in managers (6.48) than in subordinates (4.36). This indicates that managers are more inclined to solve unique problems, to implement new ideas in the work process.

To some extent, managers (3.68) are more likely than subordinates (3.10) to focus on entrepreneurship. Managers are 
"SOCIALIZATION \& HUMAN DEVELOPMENT" INTERNATIONAL JOURNAL

more independent, active, systematic in achieving economic and social results and making a profit in the organization.

At the same time, the orientation toward serving professional activities was somewhat higher among subordinates (8.36) than among managers (7.28). This may be due to their love of the profession, team or place of work.

Subordinates are also more focused on integrating their lifestyle (7.13) than managers (6.18). That is, subordinate employees, unlike managers, are more open for activities in various areas of life and the diversity of their roles.

Summarizing the above, it should be noted that it is for managers is characterized by a variety of socially determined career motivations, including the focus on professional competence, management, autonomy, challenge, entrepreneurship. Subordinates are more inclined to view their work as ministry and more focused on integrating different areas of their lives. That is, managers, more than their subordinates, are career-oriented and on a fairly wide range of social orientations.

At the next stage, we analyzed the results of the subjects with different statusrole position in the team on the questionnaire "Losses and gains of personal resources" (Authors: N. Vodopyanova, M. Stein), in order to identify the balance of their life disappointments and achievements, as a basis for the adaptive potential of the individual and his stress resilience. (See Table 2).

Table 2.Features of personal resources by status-rolepositions of employees - participants in the study

\begin{tabular}{|c|c|c|c|c|c|c|c|c|}
\hline Scales & $\begin{array}{l}\text { Status-role } \\
\text { position at } \\
\text { work }\end{array}$ & $\mathbf{N}$ & $\begin{array}{l}\text { Avera } \\
\text { ge }\end{array}$ & $\begin{array}{c}\text { Std. } \\
\text { deviation }\end{array}$ & $\mathbf{F}$ & $\begin{array}{c}\text { Significanc } \\
\text { e for } F\end{array}$ & $\mathbf{T}$ & $\begin{array}{l}\text { Significan } \\
\text { ce } \\
(2) \text { for } t\end{array}$ \\
\hline \multirow[t]{2}{*}{ 1. Staff } & $\begin{array}{l}\text { Management } \\
\text { position }\end{array}$ & 106 & 1,3876 & 4842, & ,60 & ,437 & 3,006 &, $003^{* * *}$ \\
\hline & $\begin{array}{l}\text { Ordinary } \\
\text { employee }\end{array}$ & 316 & 1,1997 &, 5 & & & 3,285 &, $001 * * *$ \\
\hline
\end{tabular}

The results presented in Table 2 show some differences in the average indicators of personal resources of managers and subordinates at the one percent level of bilateral significance $(\mathrm{p} \leq 0.01)$ according to Student's $t$ test and the absence of differences in variance or scattering of these indicators in the two samples by Fisher's F test.

It was found that managers have a higher level of personal resources (1.39) than subordinates (1.20), which indicates a greater balance of their life disappointments and achievements, their higher adaptive potential of the personality and less vulnerability for stress.

We also performed a comparative analysis of the results of the test-interview "Components of professional responsibility" (Author: LI Dementiy) of employees with different status and role positions in the workplace. (See Table 3). 
"SOCIALIZATION \& HUMAN DEVELOPMENT" INTERNATIONAL JOURNAL

Table 3. Differences in the components of professional responsibility for the status and role positions of employees

\begin{tabular}{|l|c|c|c|c|c|c|c|c|}
\hline Components & $\begin{array}{c}\text { Status-role } \\
\text { position at } \\
\text { work }\end{array}$ & $\mathbf{N}$ & Average & $\begin{array}{c}\text { Std. } \\
\text { Deviation }\end{array}$ & $\mathbf{F}$ & $\begin{array}{c}\text { Significance } \\
\text { for } \mathbf{F}\end{array}$ & $\mathbf{T}$ & $\begin{array}{c}\text { Significance } \\
\text { (2) for t }\end{array}$ \\
\hline \multirow{2}{*}{ 1. Cognitive } & $\begin{array}{c}\text { Management } \\
\text { position }\end{array}$ & 106 & 8,745 & 2,51873 & 24,204 &, $000^{* * *}$ & 6,702 &, $000^{* * *}$ \\
\cline { 2 - 9 } & $\begin{array}{c}\text { Ordinary } \\
\text { employee }\end{array}$ & 316 & 7,215 & 1,84422 & & & 5,758 &, $000^{* * *}$ \\
\hline 2. Behavioral & $\begin{array}{c}\text { Management } \\
\text { position }\end{array}$ & 106 & 9,226 & 2,63776 & 10,282 &, $001 * * *$ & 6,352 &, $000^{* * *}$ \\
\cline { 2 - 9 } & $\begin{array}{c}\text { Ordinary } \\
\text { employee }\end{array}$ & 316 & 7,541 & 2,26531 & & & 5,890 &, $000^{* * *}$ \\
\hline
\end{tabular}

Statistical analysis of the test-interview results showed that of the three components of professional responsibility: behavioral, cognitive (evaluative-reflexive) and emotional at the one percent level of bilateral significance $(\mathrm{p} \leq 0.01)$ according to the Student's $t$ - test and at the one percent level of significance $\leq 0.01$ ) according to Fisher's F test, differences between managers and subordinates were found only in the behavioral and cognitive components. It is important to emphasize that both managers and subordinates tend to both show professional responsibility in their behavior and reflect and evaluate it, although it is managers who have higher scores on these two components than subordinates (respectively 9.23 vs. 7.54, and 8.75 vs. 7.22). There were no differences in the affective component of professional responsibility of managers and subordinates.

At the next stage of our study, we analyzed the results of respondents who participated in our study on the questionnaire "Subjective Control" (Author: J. Rotter), as in previous cases, dividing them by status-role position of study participants. (See Table 4).

Table 4. Features of subjective control over the status and role positions of employees participating in the study

\begin{tabular}{|c|c|c|c|c|c|c|c|c|}
\hline Scales & $\begin{array}{c}\text { Status-role } \\
\text { position at } \\
\text { work }\end{array}$ & $\mathbf{N}$ & $\begin{array}{c}\text { Avera } \\
\text { ge }\end{array}$ & $\begin{array}{c}\text { Std. } \\
\text { deviation }\end{array}$ & $\mathbf{F}$ & $\begin{array}{l}\text { Significa } \\
\text { nce for } F\end{array}$ & $\mathbf{T}$ & $\begin{array}{l}\text { Significance } \\
\text { (2) for } t\end{array}$ \\
\hline \multirow{2}{*}{$\begin{array}{l}\text { 1. The scale of } \\
\text { general } \\
\text { internality }\end{array}$} & $\begin{array}{c}\text { Managemen } \\
\text { t position }\end{array}$ & 106 & 36,38 & 4,57024 & ,229 & ,633 & 12,908 &, $000 * * *$ \\
\hline & $\begin{array}{l}\text { Ordinary } \\
\text { employee }\end{array}$ & 316 & 29,58 & 4,73511 & & & 13,138 &, $000 * * *$ \\
\hline \multirow{2}{*}{$\begin{array}{l}\text { 2. The scale of } \\
\text { internality in the } \\
\text { field of } \\
\text { achievement }\end{array}$} & $\begin{array}{c}\text { Managemen } \\
\text { t position }\end{array}$ & 106 & 9,943 & 1,43978 & 2,665 &, 103 & 13,619 &, $000 * * *$ \\
\hline & $\begin{array}{l}\text { Ordinary } \\
\text { employee }\end{array}$ & 316 & 7,905 & 1,29609 & & & 12,925 &, $000 * * *$ \\
\hline \multirow{2}{*}{$\begin{array}{l}\text { 3. Scale of } \\
\text { internality in } \\
\text { family relations }\end{array}$} & $\begin{array}{c}\text { Managemen } \\
\text { t position }\end{array}$ & 106 & 6,227 & 1,69105 & 10,67 &, $001 * * *$ & 7,391 &, $000 * * *$ \\
\hline & $\begin{array}{l}\text { Ordinary } \\
\text { employee }\end{array}$ & 316 & 7,452 & 1,39795 & & & 6,727 &, $000 * * *$ \\
\hline
\end{tabular}


"SOCIALIZATION \& HUMAN DEVELOPMENT" INTERNATIONAL JOURNAL

\begin{tabular}{|l|l|l|l|l|l|l|l|l|}
\hline $\begin{array}{l}4 . \quad \text { Scale of } \\
\text { internality in }\end{array}$ & $\begin{array}{c}\text { Managemen } \\
\text { t position }\end{array}$ & 106 & 3,254 &, 74401 &, 076 &, 783 & 6,897 &, $000 * * *$ \\
$\begin{array}{l}\text { the field of } \\
\text { interpersonal } \\
\text { relations }\end{array}$ & $\begin{array}{l}\text { Ordinary } \\
\text { employee }\end{array}$ & 316 & 2,686 &, 73026 & & 6,833 &, $000 * * *$ \\
\hline
\end{tabular}

As we can see from Table 4, the largest differences in the mean (Student's $t$ test) and variance (Fisher's F test) between the two status-role positions were found on the scale of internality in the family relationships of the subjects. That is, subordinates are more involved in family processes and control them more than managers.

In addition, significant differences were found between the average values of the two subgroups (according to Student's t test) on the scales of general internality, internality in interpersonal relations, in the situation of achievements, in the field of health and disease. Indicators of internality in the field of failures differ in two subgroups at the five percent level ( $\mathrm{p} \leq$ $0,05)$ according to Student's t-test.

We also analyze according to table 4 the average value of these scales. Such indicators on the scale of general internality in managers (36.39) are at the highest level, nor in subordinates (29.59). Thus, managers have higher subjective control over any significant situations. According to the psychological content of the scale, managers believe that most important events in their lives were the result of their own actions, that they can control them and, therefore, take responsibility for their lives in general to a greater extent than subordinates.

The average results on the scale of internality in the field of achievement also dominate in managers (9.94), compared with subordinates (7.91). This suggests that managers on this scale have a higher level of subjective control over emotionally positive events than subordinates. Leaders believe that all the best in their lives they have achieved themselves and that they are able to successfully go to the goal in the future.

On a scale of internality in family relations (at subordinates - 7,45, at heads of the organizations - 6,23), subordinates on the average consider themselves more responsible for the events occurring in their family life unlike heads who are focused mainly on punishment.

As for the scale of internality in the field of interpersonal relations, this figure of the heads of organizations is higher than that of subordinates (3.25 vs. 2.69). This indicates that managers feel able to evoke the respect and sympathy of others, and subordinates are not entirely inclined to take responsibility for their relationships with others.

Thus, based on the analysis of the data of the questionnaire "Subjective control" we can conclude that the level of internal control in different situations is more pronounced in the heads of organizations than in subordinates, except for situations of family relations.

At the next stage of our study, we analyzed the development of the level of employee responsibility for the "Responsibility Questionnaire". S. Rudenko, dividing them by status-role position (See Table 5). 
"SOCIALIZATION \& HUMAN DEVELOPMENT" INTERNATIONAL JOURNAL

Table 5. Differences in the level of responsibility of managers and ordinary employees who participated in the study

\begin{tabular}{|c|c|c|c|c|c|c|c|c|}
\hline Scales & $\begin{array}{l}\text { Status-role } \\
\text { position at } \\
\text { work }\end{array}$ & $\mathbf{N}$ & $\begin{array}{c}\text { Averag } \\
\mathbf{e}\end{array}$ & $\begin{array}{c}\text { Std. } \\
\text { deviati } \\
\text { on }\end{array}$ & $\mathbf{F}$ & $\begin{array}{l}\text { Significanc } \\
\text { e for F }\end{array}$ & T & $\begin{array}{c}\text { Significanc } \\
\mathbf{e} \\
\text { (2) for t }\end{array}$ \\
\hline $\begin{array}{l}\text { Level of } \\
\text { responsibi } \\
\text { lity }\end{array}$ & $\begin{array}{c}\text { Management } \\
\text { position }\end{array}$ & 106 & 54,9245 & 3,29125 & 9,615 &, $002 * * *$ & 16,01 &, $000^{* * *}$ \\
\cline { 2 - 9 } & $\begin{array}{c}\text { Ordinary } \\
\text { employee }\end{array}$ & 316 & 47,2342 & 4,56163 & & & 18,76 &, $000^{* * *}$ \\
\hline
\end{tabular}

With regard to the level of professional responsibility of managers and subordinates, based on the analysis of the results presented in table 5 , it can be stated that at the one percent level of bilateral significance $(p \leq 0.01)$ the differences between the mean values of the two subsamples Significance $(p \leq 0.01)$ of differences in the variances of the two subsamples according to Fisher's F test revealed a higher level of responsibility in managers (54.92 vs. 47.23 subordinates).
This suggests that generally executives more responsible, because they are responsible not only for themselves, for their own actions and deeds, but also for other persons who are their subordinates.

At the next stage of the empirical study, we suggested that the safe and risky type of professional responsibility of the leader directly depends on the style of leadership. This hypothesis was confirmed empirically, and the results of its research are presented in table 6 .

Table 6. Features of leadership style with safe and dangerous types of professional responsibility of the individual

\begin{tabular}{|c|c|c|}
\hline \multirow[t]{2}{*}{ Leadership style } & \multicolumn{2}{|c|}{ Types of professional responsibility of the individual } \\
\hline & Safe type & Dangerous type \\
\hline Authoritarian & $78,39 * *$ & 51,92 \\
\hline Democratic & 56,41 & $89,49 * * *$ \\
\hline
\end{tabular}

(Note: ${ }^{* * *}-\mathrm{p} \leq 0.001 ; * *-\mathrm{p} \leq 0.01 ;{ }^{*}-\mathrm{p} \leq 0.05$ according to the F-Fisher criterion).

Based on the analysis of Table 6, we see that the safe type of professional responsibility is characterized by a predominantly authoritarian leadership style (78.39), and to a lesser extent liberal (60.52) and democratic (56.41). We explain the results of the study by the fact that in an authoritarian style of management, managers seek and try to subdue subordinate staff. Such leader alone determines the activities of subordinates, regulates their every step, suppresses any initiative of the specialists he manages. The dominant means of influence of such a leader (orders, instructions, orders, instructions, strict control, inhibition of creative efforts) lead to the fact that he does not take responsibility, but on the contrary in a rigid form transfers it to his subordinates.

The risky type of professional responsibility is characterized by a more democratic style of leadership (89.49), and less authoritarian (51.92) and liberal (31.25). In conditions of risk, the manager assumes part of the responsibility and solves complex and risk-related problems collectively.

The liberal style of leadership (the role of mediator), according to our research, is 
"SOCIALIZATION \& HUMAN DEVELOPMENT" INTERNATIONAL JOURNAL

not dominant in any of the types of professional responsibility.

\section{Discussion}

Theoretical and methodological analysis of the phenomenon of professional responsibility allows us to record the existence of several scientific theories and approaches to the study of the structure of professional responsibility of the individual, namely as a three-component (L. Dementiy, A. Spirkin, VF Safin, TN Sidorova, M. Svitinnia), as a factor (AP Pryadein, A. Perlin), as a functional (K. Muzdybaeva). Such a diversity of scientific vision has led to the fact that in some theories, responsibility has been interpreted rather narrowly, fragmentarily (reduction of responsibility only to its cognitive component), and in others - extremely broad.

Thus, today there are no common views on the structure of professional responsibility. The problem of external form of responsibility as acceptance of necessity became a priority in many researches (MV Mukonin, TY Bazarov, VA Bodrov, CB Bykov, AL Zhuravlyov, AB Karpov, RL Krichevsky, Yu. P. Platonoa, AL Sventsitsky). In our opinion, in research in this field, the essence of unpredictable and conflict situations as contexts of professional responsibility of the subject remains practically outside the scientific interest.

From the point of view of the authors of the article, professional responsibility of the individual can be considered as a higher and integrative professionally significant education of the individual, which reflects (or determines) the scope and quality of strategic self-control of the subject and ensures the organization of professional activity. and meeting the needs of other people (clients) in content, results and consequences of work.

Important points that have not been highlighted by other researchers in defining the phenomenon of professional responsibility is that we consider professional responsibility:

- first as a professionally significant education of a specialist, which characterizes the productive performance of professional tasks and due to creative initiative and a high level of professional self-actualization;

- secondly, through the prism of the specialist's ability to strategic self-control, which covers a long period of his activity and is associated with ways to achieve a complex goal in the performance of professional duties and tasks;

- thirdly, we study not only the content but also the consequences of the results of work, which testify to both professional responsibility and professional irresponsibility of the subject of labor

The scientific and methodological novelty of the presented study is that the subject-context approach proposed by the authors of the article is based on the idea that each subject of professional activity (specialist, manager) is forced to relate in some way to the context of external reality (to norms and rules of professional production, to the requirements of a particular place of work), while deserving of freedom of choice and action in appropriate situations. He also has the opportunity to develop personal professional responsibility in order to exercise this freedom properly. The problem is how much the subject is able to anticipate the consequences of their actions in the context of professional activities and 
"SOCIALIZATION \& HUMAN DEVELOPMENT" INTERNATIONAL JOURNAL

be responsible for them, to make independent life and professional choices and be the "author" of his life, to understand himself as a responsible person.

From the point of view of subjectcontext approach, we connect professional responsibility with personal qualities of a specialist, his freedom of choice, independence, with individual uniqueness, efficiency, humanity, locus of control, motivation to achieve, level of demands and personal resources in overcoming difficulties. Within the framework of this approach in the study of professional responsibility there are two forms objective and subjective, which can be in different, including contradictory, combinations. Responsibility in any professional field combines the fact that it is a form of control over the activities of the subject at its various stages and characterizes the responsibility from the standpoint of the micro-society (team), or individual (specialist). The personal bases of the subject of responsibility revealed by us, on the one hand, show the degree of "rootedness" of responsibility in the person, on the other - are the most important mechanisms of realization of responsible behavior at a workplace. Integrating with these personal mechanisms, responsibility acts as the most important regulator of the subject's behavior in the context of unforeseen circumstances and risk situations (situational determinants) in the workplace. Optimally responsible person increases measure of own personal responsibility in situations that, on the one hand, are significant, difficult, non-standard and personally controlled, and on the other contain the possibility of choice, leadership, risk.
To date, there are debatable issues regarding the differences between the components of professional responsibility of urban and rural residents; national and regional features of professional responsibility; possibility of influence on the professional responsibility of the individual of his / her confessional affiliation, level of education, work experience in the specialty.

\section{Conclusion}

Professional responsibility is understood by the authors as a higher and integrative professionally significant education of the individual, which reflects the scope and quality of strategic selfcontrol of the subject and ensures the organization of professional activities (and colleagues), taking into account respect, interest and satisfaction of other people (clients). in the results and consequences of work.

Differences in the professional responsibility of employees with different status and role positions in the workplace, which were identified using mathematical and statistical procedures, indicate that:

1) managerial positions require more responsibility, in contrast to the positions of subordinate staff. The leader has the responsibility to regulate, control, organize, motivate, delegate authority and activities of subordinates, and this implies that they have leadership skills that must not only have, but also improve in the process of professional activity;

2) in comparison with subordinates, managers have a higher level of personal resources, which indicates a balance of their life disappointments and achievements, a higher adaptive potential and less stress vulnerability. Significant advantages of managers (in average values) 
"SOCIALIZATION \& HUMAN DEVELOPMENT" INTERNATIONAL JOURNAL

were identified in cognitive and behavioral components of professional responsibility;

3) managers are characterized by a much greater variety of socially motivated career motivations, in particular, the focus on professional competence, management, autonomy, challenge, entrepreneurship. Subordinates are more inclined to view their work as ministry and are focused on the integration of various spheres of their lives and on self-realization on this basis.

The personal bases of the subject of responsibility revealed by us, on the one hand, show the degree of "rootedness" of responsibility as property of the person, on the other - act as the most important mechanisms of realization of responsible behavior of the person at a workplace.

\section{References}

Berkovitz L. (1968). The Traditionally socialy responsible personality. N.Y. : Public Opinion Quartely. 323.

Collins F. (2013). The Spesial Responsibility of Engeneers. The Social Responsibility of Engeneers. Annals of the New York Academy of Sciences. Vol. 196 (10), 55-68.

Davis W. L. (2017). Internal-external control and attribution of responsibility for success and failure. Journal of personality. 40, 123-136.

Helkama K. (2010). Toward a cognitiviedevelopmental theory of attribution of responsibility. Helsinki, 220 .

Ladd J. (2015). Philosophical Remarks and Professional Responsibility in Organizations. Applied Philosophy. Vol. 1 (2), 45-50.

Phares E. J. (1976). Locus of Control in Personality, Morristown. N. J. : General Learning Press. 217.

Rotter J. B. (1966). Generalized expectancies for internal versus external locus of control of reinforcement: Psychological Monographs Text. 328.

Sadova M. A. (2018). Psykholohichni skladovi profesiinoi vidpovidalnosti osobystosti [Psychological components of professional responsibility]. Odessa : Vydavets Bukaiev Vadym [in Ukrainian].

Sadova M.A. (2018). Empirical structure of professional responsibility of personality by factor analysis. Innovative solutions in modern science. Dubai, №6 (25), 112-122. 
"SOCIALIZATION \& HUMAN DEVELOPMENT" INTERNATIONAL JOURNAL

\title{
DYNAMICS OF DEVELOPMENT OF THE EDUCATORS' PROFESSIONAL SELF-CONSCIOUSNESS IN THE PROCESS OF PROFESSIONAL SKILLS IMPROVING
}

https://doi.org/00.00000/SHDISJ-00-0.0-0000

\author{
Sedykh Kira \\ https://orcid.org/0000-0003-3528-7569 \\ Metelska Nataliia \\ https://orcid.org/0000-0002-4034-9034
}

\begin{abstract}
The article is devoted to the study of the problem of dynamics of development of professional self-consciousness of educators in the process of professional skills improving. To the empirical research were involved 385 individuals - senior students who do not have professional experience; educators who at the time of the study worked on the specialty less than 5 years, from 5 to 10 years or more than 10 years.

It was found that the value-semantic component is the most important component in the self-consciousness of specialists of pedagogical profession, regardless of the level of qualification. The cognitive component gaines more weight for educators with 5 to 10 years of experience and more than 10 years of experience. The weight of the evaluative component decreases with the increase of professional experience. Emotional component acquires the greater value for pedagogues with more than 10 years of experience and the least value for educators with up to 5 years of experience. The regulatory component gaines more weight for employees with up to 5 years of experience and undergraduate students. Motivational component has the least importance for the undergraduate students. The volitional aspect of professional self-consciousness gaines the most weight for future educators.

Therefore, there are differences in the process of development of all components of educators' professional self-consciousness with different levels of qualification. Making sense of one's own professional activity and awareness of oneself as part of professional community is important, regardless of professional experience. With the increase of professional qualification, the role of professional self-esteem and selfacceptance in the activity decreases, but the level of self-understanding in the profession increases. With the increase of skills level, educators pay less attention to the issues of self-control and self-regulation in their professional activities.

Keywords: professional self-consciousness, structural components of professional self-consciousness, educators.

\section{Introduction}

The solution of the urgent tasks that are currently facing the educational system of Ukraine requires an exceptional attention to the professional training of her professional self-consciousness.
\end{abstract}


"SOCIALIZATION \& HUMAN DEVELOPMENT" INTERNATIONAL JOURNAL

The purpose of the research is to determine the dynamics of development of educators' professional self-consciousness in the process of professional skills improving.

\section{Theoretical background}

The problem of professional selfconsciousness development is not new in psychology. It was considered in the works of many researchers (B. Ananiev, M. Bakhtin, M. Kahan, O. Leontiev, etc.). General psychological and methodological aspects of professional self-consciousness are revealed in the works of K. Abulkhanova-Slavskaya,

R. Burns I. Kon, A. Petrovskyi, K. Rogers, V. Slobodchykov and others. According to their views self-consciousness should be seen as a separate phenomenon of human psychics which determines the selfregulation of person's own actions in the professional area on the basis of awareness of the profession requirements, one's abilities in the profession and emotional attitude to oneself as a subject of professional activity.

O. Bodrov, A. Derkach, Y. Kuliutkin, H. Metelskyi, D. Nikolenko, S. Pashchenko, and others devoted their attention to the analysis of formation patterns of educators professional selfconsciousness. According to scientific research of the psychological structure of personality and activity of pedagogues, improvement of their professional training and development of pedagogical skills, conducted by I. Bekh, O. Vlasova, V. KanKalyk, V. Krutetskyi, A. Kuzminskyi, A. Markova, S. Maksymenko, L. Rymar and others, the main basis for the formation of the pedagogue's personality is his or her professional self-consciousness.

According to K. Sedykh (Sedykh, 2009: 211), in recent years there has been a shift in researchers' interest from the development and description of normative models of personality and activity of a specialist to the study of professional consciousness and self-consciousness of the subject of activity.

However, an analysis of the psychological literature showed that currently there is no single approach to interpreting the concept of "professional self-consciousness of the personality". Thus, L. Mitina (Mitina, 1998) defines professional self-consciousness as the awareness of oneself in each of three components of the working space, namely in the system of one's own professional activity, in the system of professional communication and in the system of one's personality.

A. Derkach (Derkach, 2004) views professional self-consciousness as an independent psychological and acmeological category; as an evolving system; as a personal entity specific to the subject of activity. Professional selfconsciousness is manifested in personal qualities that are refracted through professional knowledge and demonstrated in the situation of professional life.

Y. Katiuk (Katiuk, 2015) defines professional self-consciousness as a complex personal entity that develops under the influence of the professional environment and the active participation of the subject in professional activity, that is, the aware attitude of a person to his or her professional needs, motives, abilities and behavior.

O. Moskalenko (Moskalenko, 2000) created an acmeological concept of the professional self-consciousness development in the context of general personal and professional formation of a person, which is aimed at achieving the 
"SOCIALIZATION \& HUMAN DEVELOPMENT" INTERNATIONAL JOURNAL

"acme", or a higher degree of selfrealization. In her research the main role of professional self-consciousness in the development of such phenomena of personality professional development as professional motivation, value orientations, psychological readiness for professional activity, professional self-affirmation, selfexpression, career growth, professional creativity is proved.

According to the scientific research of L. Mitina (Mitina, 1998) and A. Markova (Markova, 1996), the structure of the professional self-consciousness of the personality is an interconnected combination of three substructures, which are cognitive, affective and behavioral ones.

A. Derkach, O. Moskalenko and their colleagues (Derkach, Moskalenko, Piatin, Selezneva, 2000) offered their own approach to considering the structure of professional self-consciousness. They distinguished the following functional components of professional selfconsciousness: cognitive, which is realized in self-knowledge; emotional, which is realized in self-understanding; motivational and targeted, which is realized in self-actualization; operational, which is realized in self-regulation.

According to O. Priazhnykova (Pryazhnikova, 2001), the structure of professional self-consciousness includes the idea about the sense of one's work, the specific goals and objectives of professional activity, its methods and organization, about one's own formal and real job status, about oneself as a member of the working collective, about the prospects of professional and personal development, as well as about one's own real and ideal professional qualities.

Speaking about the specifics of the pedagogue's

professional

selfconsciousness, it is possible to say that it is determined with the peculiarities of the profession itself, because the profession of teacher is marked with a quite considerable list of requirements for the morality of its representatives, responsibility for the results of their work, as well as with formation of pedagogical type of thinking and self-understanding in the profession in the process of activity on the specialty (Klimov, 2003).

In foreign studies, the issue of the pedagogue's professional selfconsciousness is usually included into the context of studying his or her professional identity. Thus, A. Karaolis and G. Philippou (Karaolis, Philippou, 2019) find it necessary to consider such concepts as self-efficacy, self-esteem, professional commitment, job satisfaction, task orientation, work motivation, and future perspective while exploring this phenomenon.

According to Belgian researcher G. Kelchtermans (Kelchtermans, 1993), the structure of pedagogue's professional self includes self-image, self-esteem, job motivation, task perception, and future perspective.

However, despite increased researchers' attention to this problem, some aspects of it have not been sufficiently studied yet. Thus, the analysis of the psychological and pedagogical literature showed that until now the specifics of the development of the components of the educators' professional self-consciousness and the dynamics of these components in the course of professional experience gaining are not experimentally studied.

\section{Methodology}

The program of empirical research of educators' professional self-consciousness 
"SOCIALIZATION \& HUMAN DEVELOPMENT" INTERNATIONAL JOURNAL

includes: "Test questionnaire of selfattitude" (by V. Stolin, S. Panteleyev); "Purpose in life test" (PIL, by J. Crumbaugh, L. Maholick, adaptation by D. Leontiev); "Methods of diagnosis of personality motivation to success" (by T. Ehlers); Test questionnaire "Need for goal achievement" (by Y. Orlov); methodics "Personal differential" (adapted at the V.N. Bekhterev Research Institute variant). The research was conducted on the basis of Poltava V.G. Korolenko National Pedagogical University and the M.V. Ostrogradsky Poltava Regional Institute of Postgraduate Pedagogical Education and covered 385 people. We have identified the following categories of studied subjects:

- group 1, which consists of senior students of pedagogical specialties who have no professional experience $\left(\mathrm{n}_{1}=110\right)$;

- group 2, composed of employees of educational institutions who at the time of the study had worked on a spesialty for less than 5 years $\left(\mathrm{n}_{2}=82\right)$;

- group 3, which included pedagogues who at the time of the study worked on the specialty from 5 to 10 years $\left(n_{3}=106\right)$;

- group 4, comprised of educators who at the time of the study have worked on the specialty for more than 10 years $\left(n_{4}=87\right)$.

As we obtained a wide range of empirical data, the factor analysis with the Varimax rotation procedure with Kaiser normalization was applied to summarize and consolidate it. For the factor analysis we separated 23 variables that reflect the data of empirical research methodics. Factor analysis was conducted for each of the study groups individually in order to determine the most important peculiarities of the development of their professional self-consciousness. We used the IBM SPSS Statistics for Windows, Version 23.0 statistical software package for the detailed calculations (Pallant, 2011).

\section{Results}

At first we make a comparative analysis of the specifics of the professional self-consciousness of educators with different levels of qualification in order to identify those peculiarities of the phenomenon that are different for persons with different degrees of professional experience. We analyze the data of the first group of studied subjects - senior students of pedagogical specialties $\left(\mathrm{n}_{1}=110\right)$. According to the results of factor analysis (measure of sampling adequacy of KaiserMeyer-Olkin $=0.781), 7$ factors were extracted that explain $73.64 \%$ of total variance.

The first factor F1 (factor weight is 8.271) includes such components as "General meaningfullness of life index" (0.894), "Life efficiency, or satisfaction with self-realization" (0.815), "Life locus of control" (0.801), "Life purposes" (0.797), "Self locus of control" (0.764) and "Motivation for success" (0.407). The content of this factor reflects the degree of understanding of one's own life by undergraduate students, the vision of meaning in their life and professional way, and the ability to manage their professional activity. The factor also shows the degree of purposefulness, the ability to build life and a professional career in accordance with their goals and perceptions of their meaning, the tendency to focus on their own strengths, achieve their goal in professional activity. Summarizing the meaning of the factor, it can be considered as describing the value-semantic component of professional selfconsciousness.

The second factor F2 (factor weight is 2.239) includes such components as 
"SOCIALIZATION \& HUMAN DEVELOPMENT" INTERNATIONAL JOURNAL

"Expected attitude from others" (0.798), "Attitudes from others" (0.765), and "Selfinterest (as an attitude to one or another internal actions towards one's self)" (0.664), "Self-interest" (0.635), "Global self-attitude" (0.525), and "Selfconfidence" (0.494). This factor reflects the expectations of undergraduate students for a certain attitude from others, their tendency to self-change, the attempt to come closer to a perfect idea about the specialist, the presence of interest to their own thoughts and feelings, general selfatittude and the level of self-esteem in the professional area. So the characteristics of this factor make it possible to consider it as describing the evaluative component of professional self-consciousness.

The third factor F3 (factor weight is 1.735) includes such components as "Global self-attitude" (0.495), "Selfunderstanding" (0.790), "Self-respect" (0.787), "Self-confidence" (0.546), and "Self-management, self-consistency" (0.514). The semantics of this factor include the general self-attitude of senior students, awareness of themselves as future professionals, the degree of selfunderstanding, the ability to control their own lives and activities. Summarizing the characteristics of this factor, it can be considered as describing the cognitive component of professional selfconsciousness.

The fourth factor F4 (factor weight is 1.393) includes components such as "Global self-attitude"

(0.412), "Autosympathy" (0.843) and "Selfacceptance" (0.660). At the same time, the components "Self-blame" (-0.833) and "Motivation for success" (-0.425) were included with the negative indicator. The semantics of this factor reflect the general self-attitude of undergraduates, their self- acceptance in general, trust to themselves and positive self-esteem, acceptance of themselves as persons and specialists, lack of inclination to express unjustified accusations about themselves and tendency to avoid failure more than strive to achieve. Taking into consideration the characteristics of this factor, it can be considered as describing the emotional component of professional selfconsciousness.

Fifth factor F5 (factor weight is 1.187) includes components such as "Activity" (0.825), "Evaluation" (0.662) and "Strength" (0.565). The content of this factor reflects the activity, sociability and possible impulsivity in the area of professional activity, the degree of acceptance of oneself and one's own level of achievements in professional activity, the development of volitional aspects of the personality. Considering the characteristics of this factor, it can be considered as describing the regulatory component of professional self-consciousness.

The sixth factor F6 (factor weight is 1.070) includes components such as "The process of life, or interest and emotional saturation of life" (0.674) and the opposite relation to "Self-management, selfconsistency" (-0.609). This factor reflects students' perceptions of professional life as interesting, emotionally rich, and filled with meaning, as well as their ability to control their own lives and activities. Summarizing the content of this factor, it can be considered as describing the volitional component of professional selfconsciousness.

The seventh factor F7 (factor weight is 1.042) includes the component "Achievement motivation" (0.913). The semantics of this factor include the tendency to get involved into work, the will 
"SOCIALIZATION \& HUMAN DEVELOPMENT" INTERNATIONAL JOURNAL

to do things better than before, and the need to invent new ways of doing ordinary tasks. Therefore, the characteristics of this factor make it possible to consider it as describing the motivational component of professional self-consciousness.

Next, we analyze the data of the second group of respondents, employees of educational institutions who at the time of the study worked on the specialty for less than 5 years $\left(\mathrm{n}_{2}=82\right)$. According to the results of factor analysis (measure of sampling adequacy of Kaiser-Meyer-Olkin $=0.748), 6$ factors were extracted that explain $70.11 \%$ of total variance.

The first factor F1 (factor weight is 7.557) includes such components as the "General meaningfullness of life index" (0.943), "Life locus of control" (0.878), "The process of life, or interest and emotional saturation of life" (0.814), "Life efficiency, or satisfaction with selfrealization" (0.806), "Life purposes" (0.789), "Self locus of control" (0.712), "Global self-attitude" (0.558), "Selfrespect" (0.545), and "Self-confidence" ( 0.427). The semantics of this factor reflect the degree of understanding of one's life by educators with little work experience, their ability to make decisions and implement them freely, as well as a sense of the segment of life as a productive and meaningful part of their professional way, the existence of purposes in the future, which give the meaningfulness, focus and time perspective to life. Substantive meaning of this factor includes sufficient freedom of choice to build one's life and professional career in accordance with one's goals and ideas about their meaning, the general self-attitude of pedagogues and their level of self-esteem, trust to their abilities, understanding of their own role in professional success achieving.
Summarizing the characteristics of this factor, it can be considered as describing the value-semantic component of professional self- consciousness.

The second factor F2 (factor weight is 2,594 ) includes such components as "Selfinterest" (0.784), "Self-interest (as an attitude to one or another internal actions towards one's self)" (0.780), "Expected attitude from others" ( 0.729$)$ and "Attitudes from others" (0.667). The content of this factor reflects a tendency to self-change in order to get closer to the ideal idea of oneself, the interest to one's own thoughts and feelings as a specialist, the idea of how educators are able to arouse respect, sympathy, approval or understanding from others. Taking into consideration the characteristics of this factor, it can be considered as describing the evaluative component of professional self-consciousness.

The third factor F3 (factor weight is $1.865)$ includes such components as "Selfunderstanding"

"Selfmanagement, self-consistency" $(0.721)$ and "Self-respect" (0.561). This factor reflects the employees' awareness of themselves as specialists, their ability to control their own lives and activities, and their level of understanding of their professional capacities. Taking into consideration the characteristics of this factor, it can be considered as describing the cognitive component of professional selfconsciousness.

The fourth factor F4 (factor weight is 1.584) includes such components as "Activity" (0.731), "Motivation for success" (0.676), "Strength" (0.609) and "Evaluation" (0.544). The semantics of this factor include activity, sociability in professional behavior, attitude to oneself and one's own level of achievement, in 
"SOCIALIZATION \& HUMAN DEVELOPMENT" INTERNATIONAL JOURNAL

particular in professional activity, development of volitional aspects of the personality, tendency to focus on one's own strengths, achieve the set purpose in professional activity. Summarizing the characteristics of this factor, it can be considered as describing the regulatory component of professional selfconsciousness.

The fifth factor F5 (factor weight is $1.321)$ includes components such as "Selfacceptance" (0.795), "Self-confidence" (0.485), and "Autosympathy" (0.594). The semantics of this factor reflect a sense of sympathy for oneself, the acceptance of educators by themselves as they are, the attitude to themselves as volitional and reliable ones, a sense of themselves as regulators of achievement and professional success, the approval of themselves in general, trust to themselves and self-esteem of educators. Thus, the substantive capacity of this factor makes it possible to consider it as describing the emotional component of professional self-consciousness.

The sixth factor F6 (factor weight is 1.204) includes the component "Autosympathy" (0.636). At the same time, the components "Self-blame" (-0.813) and "Achievement motivation" (-0.545) were included with the negative indicator. The content of this factor reflects the pedagogues' trust to themselves, the lack of a tendency to express unjustified accusations about themselves, satisfaction with the achieved and lack of will to enjoy the pleasure of life and professional achievements in any case. Summarizing the characteristics of this factor, it can be considered as describing the motivational component of professional selfconsciousness.

Let us analyze the data of the third group of respondents - employees of educational institutions who at the time of the study worked on the specialty from 5 to 10 years $\left(n_{3}=106\right)$. According to the results of factor analysis (measure of sampling adequacy of Kaiser-Meyer-Olkin $=0.746), 6$ factors were extracted that explain $71.73 \%$ of total variance.

The first factor F1 (factor weight is 7,928 ) includes such components as the "General meaningfullness of life index" (0.954), "Life locus of control" (0.864), "Self locus of control" (0.801), "Life purposes" (0.781), "Life efficiency, or satisfaction with self-realization" (0.759), "The process of life, or interest and emotional saturation of life" (0.747), "Selfconfidence" (0.478), "Global self-attitude" (0.478), "Self-understanding" (0.402) and "Self-respect" (0.465). This factor reflects the degree of meaningfulness of one's life, orientation to one's semantic directions, conviction in one's ability to control his or her own life in order to build a professional career in accordance with one's goals and ideas about their meaning, a sense of one's professional career as a meaningful, interesting, emotional rich and contented part of life, general self-attitude of educators, awareness of the value of themselves as specialists, trust to their own strength. Considering the characteristics of this factor, it can be seen as describing the value-semantic component of professional self-consciousness.

The second factor F2 (factor weight is 2,553 ) includes such components as "Global self-attitude" (0.437), "Autosympathy" (0.911), and "Selfacceptance" (0.643). At the same time, components "Self-blame" (-0.801) and "Achievement motivation" (-0.504) were included into this factor with negative index. The semantics of this factor include the general self-attitude of educators, 
"SOCIALIZATION \& HUMAN DEVELOPMENT" INTERNATIONAL JOURNAL

understanding and acceptance of themselves as they are, lack of inclination to make unjustified accusations about themselves, enjoyment of easy success and simple tasks in professional activity. Considering the characteristics of this factor, it can be seen as describing the cognitive component of professional selfconsciousness.

The third factor F3 (a factor weight of 2,096), includes components such as "Attitudes from others" (0.871), "Expected attitudes from others" (0.859), and "Selfmanagement, self-consistency" (0.432). The semantics of this factor reflect an idea of the extent to which their personality is capable of arousing the respect, sympathy, approval or understanding of others, the ability to control their own lives and activities. Summarizing the characteristics of this factor, it can be considered as describing the evaluative component of professional self-consciousness.

The fourth factor F4 (factor weight is 1.572) includes components such as "Global self-attitude" (0.453), "Selfinterest" (0.837) and "Self-interest (as an attitude to one or another internal actions towards one's self)" (0.822). The content of this factor reflects an internally undifferentiated sense of "for" or "against" oneself, an attempt to come closer to a perfect idea of oneself, an interest to one's own thoughts and feelings, a willingness to communicate with oneself on an equal basis with both one's personality and professional self. Thus, the meaning of this factor make it possible to consider it as describing the emotional component of professional self-consciousness.

The fifth factor F5 (factor weight is 1.224) includes such components as "Evaluation" (0.783), "Motivation for success" (0.629), "Self-respect" (0.517) and "Self-management, self-consistency" (0.500). This factor reflects the degree of acceptance of oneself as a person and the level of satisfaction with oneself, the presence of a critical attitude towards oneself and one's own level of achievements in professional activity, the tendency to focus on one's own strengths, to achieve one's goal in professional activity, the ability to control one's own activity and to be self-consistent in achieving the results. Summarizing the characteristics of this factor, it can be considered as describing the motivational component of professional selfconsciousness.

The sixth factor F6 (factor weight is $1.124)$ includes components such as "Activity" (0.849) and "Strength" (0.552). The semantics of this factor include the activity, sociability and possible impulsivity in the area of professional activity, the development of the volitional aspects of the personality, which affects their professional functioning. Considering the characteristics of this factor, it can be seen as describing the regulatory component of professional selfconsciousness.

Let us analyze the data of the fourth group of respondents - employees of educational institutions, who at the time of the study worked on the specialty for over 10 years $\left(\mathrm{n}_{4}=87\right)$. According to the results of factor analysis (measure of sampling adequacy of Kaiser-Meyer-Olkin $=0.776$ ), 6 factors were extracted, which explain $71.72 \%$ of total variance.

The first factor, F1 (factor weight is 8,699 ), includes such components as the "General meaningfullness of life index" (0.891), "The process of life, or interest and emotional saturation of life" (0.784), "Life locus of control" (0.765), "Life efficiency, 
or satisfaction with self-realization" (0.732), "Self locus of control" (0.682), "Life purposes" (0.656), "Achievement motivation" (0.632), "Strength" (0.419), and "Self-respect" (0.454). The semantics of this factor reflect the degree of understanding of one's life by the studied subjects, the conviction of being able to control one's life, to make decisions and implement them freely, as well as to manage one's professional activity, the feeling of the passed segment of life as a productive and meaningful part of one's life and professional way, persistence in achievement of one's goals in professional activity, presence of goals in the future, development of volitional aspects of the personality, self-understanding, independence. Considering the meaning of this factor, it can be seen as describing the value-semantic component of professional self-consciousness.

The second factor F2 (factor weight is 2,425 ) includes such components as "Autosympathy" (0.842), "Global selfattitude" (0.626), "Self-understanding" (0.575), "Self-respect" (0.547) and "Selfacceptance" (0.643). The component "Selfblame" (-0.869) was included into this factor with negative index. The content of this factor reflects sociability or hostility to one's self, internally undifferentiated sense of "for" or "against" oneself, value of their personality for educators, awareness of themselves as specialists, evaluation of their capabilities, ability to control their life, acceptance of themselves as they are, understanding of themselves as persons and specialists, lack of inclination to consider themselves as the cause of troubles that occur in the professional environment. Summarizing the characteristics of this factor, it can be considered as describing the cognitive component of professional self-consciousness.

The third factor F3 (factor weight is 1.517) includes such components as "Global self-attitude" (0.414), "Selfacceptance" (0.410), "Self-interest" (0.893), and "Self-interest (as an attitude to one or another internal actions towards one's self)" (0.816). This factor reflects an internally undifferentiated sense of "for" or "against" oneself, the general self-attitude of pedagogues and their level of selfesteem, which extends to the professional area, the tendency to self-change, the degree of closeness to themselves, feelings of sympathy to themselves, acceptance of themselves as they are, harmony with their internal intentions. Therefore, the characteristics of this factor make it possible to consider it as describing the emotional component of professional selfconsciousness.

The fourth factor F4 (factor weight is 1.439) includes such components as "Activity" (0.765), "Self-confidence" (0.656) and "Motivation for success" (0.646). The semantics of this factor include activity, sociability and possible impulsivity in professional activity, the idea of the main source of one's own activity, results and achievements, the tendency to focus on one's own strengths, to achieve one's goal in life and one's professional activity. Summarizing the characteristics of this factor, it can be considered as describing the motivational component of professional selfconsciousness.

The fifth factor F5 (factor weight is 1.250) includes components such as "Attitude from others" (0.910) and "Expected attitude from others" (0.764). The semantics of this factor reflects the perceptions of educators about the extent to which they are able to arouse respect, 
"SOCIALIZATION \& HUMAN DEVELOPMENT" INTERNATIONAL JOURNAL

sympathy, approval or understanding from others. Summarizing the characteristics of this factor, it can be considered as describing the evaluative component of professional self-consciousness.

The sixth factor F6 (the factor weight is 1.164) includes such components as "Self-management, self-consistency" (0.766) and "Evaluation" (0.727). The content of this factor reflects the ability of educators to control their lives and activities carefully, accepting themselves as personalities and satisfaction with themselves, critical attitude to themselves and their own level of achievement in professional activity. Taking into account the meaning of this factor, it can be considered as describing the regulatory component of professional self- consciousness.

Generalized factor analysis data for the entire sample of subjects are presented in Table. 1.

Analyzing the data in the table, we can conclude that the value-semantic component is the main in the structure of professional self-consciousness of educators at all stages of professional experience gaining (average rank $=1$ ), that is, the ability of the professional to understand the surrounding reality, establish personal sense of activity and ideas connected with the profession, is the most important component in the selfconsciousness of pedagogical professionals, regardless of the level of qualification.

Table 1. The hierarchy of empirically selected factors in the structure of professional self-consciousness of educators

\begin{tabular}{|l|c|c|c|c|c|}
\hline \multirow{2}{*}{$\begin{array}{c}\text { Components of } \\
\text { professional self- } \\
\text { consciousness }\end{array}$} & \multicolumn{4}{|c|}{ Ranks for research groups } & $\begin{array}{c}\text { Average rank } \\
\text { for a component }\end{array}$ \\
\cline { 2 - 5 } & $\begin{array}{c}\text { group 1 } \\
\text { (0 years) }\end{array}$ & $\begin{array}{c}\text { group } 2 \\
(0-5 \text { years })\end{array}$ & $\begin{array}{c}\text { group 3 } \\
(5-10 \text { years })\end{array}$ & $\begin{array}{c}\text { group } 4 \\
(10-\ldots \text { years })\end{array}$ & \\
\hline Value-semantic & 1 & 1 & 1 & 1 & 1 \\
\hline Evaluative & 2 & 2 & 3 & 5 & 3 \\
\hline Cognitive & 3 & 3 & 2 & 2 & 2,5 \\
\hline Emotional & 4 & 5 & 4 & 3 & 4 \\
\hline Regulatory & 5 & 4 & 6 & 6 & 5,25 \\
\hline Volitional & 6 & - & - & - & 6 \\
\hline Motivational & 7 & 6 & 5 & 4 & 5,5 \\
\hline
\end{tabular}

Cognitive component of professional self-consciousness of educators can be considered as one of the leading ones (average rank $=2.5$ ), that is awareness of oneself as a person and a specialist, understanding of the characteristics of one's profession, professional community, the ideal of the pedagogue, as well as one's professionally important qualities. This component gaines more weight with the development of professional qualification, namely, for educators with 5 to 10 years of experience and more than 10 years of working experience.

Educators with up to 5 years of experience and undergraduate students are more likely to give more weight to the evaluative component than to cognitive component of professional selfconsciousness (average rank $=3$ ), which is seen by us as an integral part of the emotional-evaluative component and is expressed in self-esteem and selfacceptance of oneself as a specialist. The 
"SOCIALIZATION \& HUMAN DEVELOPMENT" INTERNATIONAL JOURNAL

weight of this component decreases with the growth of professional experience.

The next in the hierarchy of components is the emotional component (average rank $=4$ ), which we understood as an integral part of the emotional-evaluative component, as the previous one. It is expressed in the attitude of educators to themselves as professionals, which is manifested in self-esteem, self-respect, self-interest, sympathy for oneself as a representative of the teaching profession. The emotional component becomes more important for educators with more than 10 years of experience, and the least important for educators with up to 5 years of experience.

The regulatory component, which is the next in the hierarchical structure of professional self-consciousness of educators (average rank $=5.25$ ), manifests itself in self-regulation while pedagogical tasks solving, in potential behavioral reactions in situations of professional activity, in goals setting and achieving. This component gaines more weight for workers with up to 5 years of experience and undergraduate students, and as their professional skills grow, its weight decreases.

The next is the motivational component of the professional selfconsciousness of educators (average rank $=$ 5.5), which consists of professional motivation, motives for professional improvement that provide the need for selfactualization, and the will to succeed in professional activity. Motivational component has the least weight for the undergraduate students, but it gradually increases with the pedagogues' professional skills improving.

Another component identified during the analysis was volitional, which was extracted only for senior students (average rank $=6$ ). We understand this component as an integral part of the regulatory one, which finds expression in the development of volitional qualities, the ability to control one's own life and activities with their help. In this regard, we can say that the volitional aspect of professional self-consciousness gaines the biggest weight for future educators.

\section{Discussion}

Thus, the value-semantic component, that is, the professional's ability to comprehend the surrounding reality, establish personal meaning of activities and ideas related to the profession, is the most important component in the self-consciousness of professionals of the teaching profession, regardless of the level of qualification. The cognitive component gaines more weight with the growth of professional skills, namely, for educators with 5 to 10 years of experience and more than 10 years of working experience. The weight of the evaluation component decreases with the increase of professional experience. Emotional component acquires the biggest value for pedagogues with more than 10 years of experience and the least value for educators with up to 5 years of experience. The regulatory component gaines more weight for workers with up to 5 years of experience and undergraduate students, and as their professional skills grow, its weight decreases. The undergraduate students have the least value of motivational component, but it increases gradually with the professional development of teachers. The volitional aspect of professional self-consciousness gaines the biggest weight for future educators. 
"SOCIALIZATION \& HUMAN DEVELOPMENT" INTERNATIONAL JOURNAL

The results of our study are to a certain extent confirmed by the data of scientific research of E. Maksimović and E. Osmanović (Maksimović, Osmanović, 2019), who came to the conclusion that work experience influences the peculiarities of teachers' self-concept development. Thus, scientists proved the dependence of acceptance of teachers' own selves, self-improvement, satisfaction with their own selves, their achievements and their own profession as a whole on the level of qualification.

\section{Conclusion}

Thus, the results of the comparative study showed that there are differences in the level of development of all components of educators' professional selfconsciousness with different levels of qualification. Making sense of one's professional activity and awareness of oneself as a part of a professional community is important, regardless of professional experience. With the increase of professional qualification, the role of professional self-esteem and selfacceptance in activity decreases, but the level of self-understanding in the profession increases. With the increase of skills level, educators pay less attention to the issues of self-control and selfregulation in their professional activities. This is confirmed by the fact that volitional qualities in the structure of professional self-consciousness are allocated for themselves only by students without professional experience. Also, as the level of qualification increases, the motivation for professional activity becomes more important, that is, pedagogues are more able to pay attention to the need for selfactualization.

The conducted research does not exhaust all aspects of the problem under study. Prospects for further exploration are to study the structure of professional selfconsciousness of educators, depending on their specialization.

Conflict of interest. We state that there is no conflict of scientific interests.

\section{References}

Derkach, A. A. (2004). Akmeologicheskie osnovy razvitiya professionala [Acmeological bases of the professional development]. Moscow: Izdatelstvo Moskovskogo psihologo-sotsialnogo instituta [in Russian].

Derkach, A. A., Moskalenko, O. V., Pyatin, V.A. \& Selezneva, E. V. (2000). Akmeologicheskie osnovy professionalnogo samosoznaniya lichnosti [Acmeological bases of professional self-consciousness of personality]. Astrahan: Izdatelstvo Astrahanskogo gosudarstvennogo pedagogicheskogo universiteta [in Russian].

Karaolis, A., Philippou, G.N. (2019). Teachers' Professional Identity. In: Hannula, M., Leder, G., Morselli, F., Vollstedt, M., Zhang, Q. (eds) Affect and Mathematics Education. ICME13 Monographs. Springer, Cham.

Katiuk, Y. L. (2015). Osobystisnooriientovani zasady rozvytku profesiinoi samosvidomosti maibutnikh psykholohiv u systemi pisliadyplomnoi pedahohichnoi osvity [Personally oriented principles of development of professional self-consciousness of future psychologists in the system of postgraduate pedagogical education]. In Osobystisnooriientovana pidhotovka maibutnikh psykholohiv $\mathrm{u}$ systemi 
"SOCIALIZATION \& HUMAN DEVELOPMENT" INTERNATIONAL JOURNAL

pisliadyplomnoi pedahohichnoi osvity [Personally-oriented training of future psychologists in the system of postgraduate pedagogical education]. Kyiv: NAPN of Ukraine, Universytet menedzhmentu osvity, 127-152 [in Ukrainian].

Kelchtermans, G. (1993) Getting the story, understanding the lives: from career stories to teachers' professional development. Teaching and Teacher Education, 9 (5 / 6), 443-456.

Klimov, E. A. (2003). Psihologiya professionala: izbrannye psihologicheskie trudy [Professional psychology: selected psychological works]. Moscow: Izdatelstvo Moskovskogo psihosotsialnogo instituta; Voronezh: Izdatelstvo NPO "MODEK" [in Russian].

Maksimović, J. \& Osmanović, J. (2019). Teachers' self-concept and its benefits for science education. Journal of Baltic Science Education, vol. 18, 1. 105-116.

Markova, A. K. (1996). Psihologiya professionalizma [Psychology of professionalism]. Moscow: Mezhdunarodnyiy gumanitarnyiy fond "Znanie" [in Russian].

Mitina, L. M. (1998). Psihologiya professionalnogo razvitiya uchitelya [Psychology of teacher professional development]. Moscow: Flinta [in Russian].
Moskalenko, O. V. (2000). Razvitie professionalnogo samosoznaniya rukovoditeley obrazovatelnyh uchrezhdeniy [Development of professional self-consciousness of the heads of educational institutions] (Extended abstract of $\mathrm{PhD}$ dissertation). Moscow: Russian Presidential Academy of Public Administration [in Russian].

Pallant, J. (2011). SPSS survival manual: A step by step guide to data analysis using the SPSS program. 4th Edition, Allen \& Unwin, Berkshire.

Pryazhnikova, E. Y. (2001). Psihologicheskie osnovy razvitiya professionalnogo samosoznaniya profkonsultanta [Psychological bases of the development of professional self-consciousness of a professional consultant] (Extended abstract of Doctoral dissertation). Tver: Tver State University [in Russian].

Sedykh, K. V. (2009). Supervizii dlia shkilnykh psykholohiv-konsultantiv [Supervisions for school counseling psychologists]. In Aktualni problemy psykholohii [Actual problems of psychology]. Kyiv: Instytut psykholohii imeni H.S. Kostiuka NAPNU, vol. 7, 19, 211215 [in Ukrainian]. 
"SOCIALIZATION \& HUMAN DEVELOPMENT" INTERNATIONAL JOURNAL

\title{
EMPATHIC INTERACTION OF ADOLESCENTS: PSYCHOLOGICAL PECULIARITIES AND CORRELATES
}

https://doi.org/00.00000/SHDISJ-00-0.0-0000

\author{
Shistko L.O. \\ ORCID: 0000-0003-1972-5514 \\ Riabchych I.Y. \\ ORCID: 0000-0002-3216-5059 \\ Prokopovych Y.M. \\ ORCID: 0000-0002-8601-5419
}

\begin{abstract}
The goal of this article is to present the psychological peculiarities and correlates of the empathic interaction of adolescents. Methodology meet the following steps:the first was the diagnosis of empathy of the subjects and the frequency of manifestations of each type of empathy interpersonal interaction was determined; on the second were diagnosed cognitive, emotional, motivational and value-meaning individual-psychological qualities and features of young people, which are important for the situation of interpersonal interaction; in the third stage, the relationships between each type of empathic interpersonal interaction and the personal indicators of the subjects were determined. For this purpose, the Pearson linear correlation method was used. Seven species of the latter are described. An empathogenic situation is required to activate the empathy process. The latter refers to the intense production of emotions, emotions, moods, thoughts, states of personality that resonate with the corresponding mental processes and states of other people. The received signals about the inner state на another person is only information perceived by the individ. The effective response to this information will depend on the needs that dominate in the personality structure. Discussion shows that from the outlined point of view, we believe that depending on different circumstances (the level of empathy as an integrative indicator, as well as actual (situational) needs and states of personality), information about the internal state of another may be perceived by actualizing a certain type of empathic response, or not perceived. The dissonant interaction is characterized by a confronting psychological position, nonconformist cognitive orientation, low level of emotional maturity, manifested in low control of emotions and indistinct manifestation, pessimistic emotional modality, eccentric modality. All these characteristics were accompanied by the lack of need to interact and the depreciation of the Other.
\end{abstract}

Keywords: empathy, empathic, empathogenetic situation, empathic interpersonal interaction, young age.

\section{Introduction}

Interpersonal interaction is an integral part of a person's life. Its effectiveness often depends on the measure of subjective well-being and psychological comfort of the individual, the success of comprehensive self-realization and so on (Prokopovych, 2017; Riabchych, 2018). In this context, finding ways to improve the effectiveness of interpersonal relationships 
"SOCIALIZATION \& HUMAN DEVELOPMENT" INTERNATIONAL JOURNAL

is of particular importance. Under such conditions, research into empathic interpersonal interaction may be a promising area of scientific search.

A review of scientific sources showed that the vast majority of scientists (I. Bech, N. Bulatevich, I. Danyliuk, L. Zhuravleva, O. Zaporozhets, N. Kalina, I. Kozytska, A. Mambetova, Y. Prokopovych, I. Riabchych, S. Shykovets, O. Vlasova, etc.) consider empathy in the context of interpersonal interaction, but no comprehensive experimental study of their relationship has been conducted.

The article purpose is to present to present the psychological peculiarities and correlates of the empathic interaction of adolescents.

\section{Theoretical background}

Research has shown that empathy permeates every element of interpersonal interaction. Its updating at one stage or another directly affects the nature of its course. The peculiarities of this influence are determined by the level of empathy development of the subjects of interpersonal interaction. Thus, depending on whether empathy during interpersonal contact was actualized or not, any interpersonal interaction can be divided into empathic or non-empathic.

Empathic interaction means the accidental or intentional, private or public, long-term or short-term, verbal or nonverbal, direct or indirect personal contact of two or more people during which the empathy of at least one of the subjects of the interaction is actualized (Danyliuk, Kozytska \& Shykovets, 2018; Shykovets, Mambetova, 2018).

According to L. Zhuravleva (Zhuravl'ova, 2007: 40), an empathogenic situation is required to activate the empathy process. The latter refers to the intense production of emotions, emotions, moods, thoughts, states of personality that resonate with the corresponding mental processes and states of other people. According to the basic principles of the information theory of emotions, the received signals about the inner state of another is only information perceived by the individual. The effective response to this information will depend on the needs that dominate the personality structure (Simonov, 1981). From the outlined point of view, we believe that depending on different circumstances (the level of empathy as an integrative indicator, as well as actual (situational) needs and states of personality), information about the internal state of another may be perceived by actualizing a certain type of empathic response, or not perceived (Vlasova, 2019; Bulatevich, Mambetova, 2018). If it is not perceived by the individual, then the empathic process is not actualized and in this particular situation or interpersonal interaction does not occur at all, or non-empathetic interpersonal interaction is implemented. If, however, a person has perceived and realized this information about another, then interpersonal interaction will be implemented in accordance with actualized forms of empathy (Zhuravl'ova, 2007). Consider possible options for its development:

1. The personality was aware of the inner state of the other, but her attention was shifted by a more significant stimulus. At first glance, empathic engagement never happened. At the same time, we see that the empathic process was started, but was interrupted initially. In this case, empathy was realized in the form of indifference. Therefore, we can talk about interrupted (indifferent) empathic interaction.

2. The person realized the inner state 
"SOCIALIZATION \& HUMAN DEVELOPMENT" INTERNATIONAL JOURNAL

of the other, there was an emotional switch from his experiences to his own, the mechanism of identification worked, there was empathy. However, the immersion in one's own experiences has gone so deep that the experiences of another have lost their relevance. In this way, self-centered empathic interpersonal interaction was realized.

3. The personality was aware of the inner state of the other, there was an emotional switch from his experiences to his own, the mechanism of identification worked, there was an empathy that was amenable to reflection. Reflected information facilitated the assessment of the situation, the decentration and the emergence of emotions regarding the inner state of the empath (personality, which intensively produces emotions, emotions, moods, thoughts, states). An empathic person (a person who perceives information about emotions, emotions, moods, thoughts, states of empathy and responds to them in some way) felt sympathy, compassion and more. If the affective sphere is dominant in the personality structure, then the empathic process at this stage may be interrupted. This kind of empathetic interpersonal interaction is subject-centric.

4. Feeling sympathetic or empathetic to one's personality there is a need for assistance. It models different options for assistance, selects resources, develops an internal action plan, and more. An empathic person has an intention that is not always embodied in real action. The kind of empathic interpersonal interaction in which real assistance does not take place is called intentional.

5. If the intention is embodied in the process of interaction, taking into account their own interests (not to harm them), then a conducive empathic interaction is realized.

6. When a person helps another, leveling their desires, needs, interests, we can talk about the realization of altruistic empathic interpersonal interaction.

7. It is often the case that when one perceives information about another's inner state, one's emotions and aspirations arise in the personality, which are opposite to the empath's experiences and needs. In this case, anti-empathy was actualized, which can be realized on several levels: from anger or gloating and to real counteraction, or even sadistic pleasure from the feeling of suffering of the Other (Zhuravl'ova, 2007: 49-67). Anti-empathy, as well as empathy, has its functions, mechanisms, determinants, forms of manifestation, etc. that have yet to be established. Since we have not encountered such research, we consider it possible to combine all forms of anti-empathy into one type of empathic interpersonal interaction - dissonant. Note that with the advent of the classification of forms of dissonant empathy, it will be quite natural to further differentiate dissonant empathic interaction.

A person's propensity to engage in one or another type of empathic interpersonal interaction can be determined by various factors. We can distinguish at least three of them:

1. Objective, which include the complexity of the empathogenic situation, the conditions in which it occurs, the presence of other people, age, gender of the empath, family ties with him, etc.

2. Situational to which we refer the mood of the empathic, the extent of his concern and the nature of activity at the moment of the empathogenic situation, the reactions of others to it, etc.

3 . Subjective relating to the individual 
"SOCIALIZATION \& HUMAN DEVELOPMENT" INTERNATIONAL JOURNAL

characteristics and qualities of the empathic personality.

If the first and the second species are difficult to predict and investigate (due to innumerable variations), the latter factor is easily empirically studied.

\section{Methodology \\ Methodology}

(Sample, Instruments/Methods, Procedure) meet the following steps:

- the first was the diagnosis of empathy of the subjects and the frequency of manifestations of each type of empathy interpersonal interaction was determined;

- on the second were diagnosed cognitive, emotional, motivational and value-meaning individual-psychological qualities and features of young people, which are important for the situation of interpersonal interaction;

- in the third stage, the relationships between each type of empathic interpersonal interaction and the personal indicators of the subjects were determined. For this purpose, the Pearson linear correlation method was used.

The study used the following techniques: "Empathy test for adolescents and adolescents" by L. Zhuravleva (Zhuravleva, 2010), "Subjective evaluation of interpersonal relationships" S. Dukhnovsky (Dukhnovsky, 2009), "Dialogue of Interpersonal Relations" by S. Dukhnovsky (Dukhnovsky, 2009), "Diagnosis of Motivational Orientations in Interpersonal Communication" by I. Ladanov and V. Urazaeva (Fetiskin, Kozlov \& Manujlov, 2002: 68), "Diagnosis of emotional barriers in interpersonal communication" V. Boyko (Fetiskin, Kozlov \& Manujlov, 2002: 118), "Diagnosis of interactive personality orientation" by N. Shchurkov in modification by N. Fetiskin (Fetiskin,
Kozlov \& Manujlov, 2002: 59), "The Need for Communication" by O. Eliseev (Eliseev, 2001), "The Communication Direction Questionnaire (UFO)" S. Bratchenko (Bratchenko, 1997).

The study involved 120 adolescents. Statistical processing of data was carried out using the SPSS software package.

\section{Results}

As a result of the analysis of the empirical material obtained, a system of reliable correlates of the above types of empathic interpersonal interaction identified above (see Table 1) was revealed. Thus, statistically significant correlates of interrupted empathic interpersonal interaction are such indicators of the cognitive component of interpersonal interaction as cognitive styles of psychological orientation $(\mathrm{r}=-0.218 ; \mathrm{p}$ $\leq 0.001)$ and reflexive assessment of one's own "I" as a social percept $(\mathrm{r}=-0.154 ; \mathrm{p}$ $\leq 0.05$ ). Among the indicators of the emotional component revealed a reliable relationship only with the emotional modality of interaction $(r=-0,263 ; p \leq$ 0,001 ), and the motivational - with the affective $(r=-0,122 ; p \leq 0,1)$ and selfish $(r=0,122 ; p \leq 0,1)$ motivational orientation, as well as the need for interaction $(\mathrm{r}=-$ $0,105 ; \mathrm{p} \leq 0,1)$. The value-meaning component revealed statistically significant interconnections of interrupted empathic interaction with the alterocentric $(\mathrm{r}=-$ $0.284 ; p \leq 0.001)$, dialogic $(r=-0.239 ; p$ $\leq 0.001)$, authoritarian $(\mathrm{r}=0.116, \mathrm{p} \leq 0.1)$, manipulative $(\mathrm{r}=0,187 ; \mathrm{p} \leq 0,01)$ and indifferent $(r=0,104 ; p \leq 0,1)$ value-sense orientation.

Qualitative analysis of the results showed that for persons who implement interrupted empathic interaction inherent in the autonomy of judgment, indifference to the opinion of others, rigidity, suspicion, 
"SOCIALIZATION \& HUMAN DEVELOPMENT" INTERNATIONAL JOURNAL

sense of helplessness and hopelessness, low level of need for interaction, vivid expression, vivid expression, business cooperation, selfish motivational orientation. We believe that all these characteristics can be both individual personality traits (those that manifest themselves in the vast majority of personal interactions), and situational (occur in a specific situation with a specific Other). We assume that the presence of at least one of these indicators increases the likelihood of indifferent behavior in an empathic situation.
In addition, we can observe that the largest number of correlates of indifferent empathy interaction is concentrated in the value-semantic component of interpersonal interaction. Obviously, the most valuable relationship to the Other is the key to this type of interaction. Therefore, indifferent interaction is possible only when the Other is not of value to the empathic, and therefore his thoughts, experiences, feelings, etc. lose their significance. Conversely, if empathy is a significant personality, then more developed types of empathic interpersonal interaction are likely to be realized.

Table 1. Matrix of significant linear correlation coefficients between empathy interaction components and interpersonal interaction components in adolescence

\begin{tabular}{|c|c|c|c|c|c|c|c|c|}
\hline Components & $\begin{array}{c}\text { Indicat } \\
\text { or }\end{array}$ & $\mathbf{P}$ & $\mathbf{E}$ & $\mathbf{C}$ & $\mathbf{H}$ & $\mathrm{Cn}$ & $\mathbf{A}$ & D \\
\hline \multirow[t]{4}{*}{ Cognitive } & CSD & & & 181 & & & -143 & \\
\hline & CSP & & -111 & & & & & 153 \\
\hline & CBS & $-218^{*}$ & & -120 & & $24 *$ & 131 & -116 \\
\hline & ROI & 154 & & & & & & 132 \\
\hline \multirow[t]{9}{*}{ Emotional } & KEM & & & $\underline{177}$ & & -134 & -164 & \\
\hline & NP & & & & & & & \\
\hline & NNEM & & 182 & & & -184 & -142 & 132 \\
\hline & DAY & & & & & -145 & & \\
\hline & NZL & & & & & & -194 & \\
\hline & EMB & & 124 & 137 & & -174 & -164 & 106 \\
\hline & EMV & & & 143 & & & -109 & \\
\hline & EMM & $-263 *$ & -152 & -15 & & $293^{*}$ & $184^{*}$ & $-226^{*}$ \\
\hline & EMC & & & & & & & 107 \\
\hline \multirow{6}{*}{ Motivational } & EgMO & 122 & & & & -149 & & $223 *$ \\
\hline & AFMO & -122 & -196 & & & 176 & & $-287 *$ \\
\hline & QMS & & & 116 & & & & 159 \\
\hline & PV & -105 & -169 & & & & $207 *$ & $-225^{*}$ \\
\hline & $\mathrm{SS}$ & & -166 & & & 134 & 106 & \\
\hline & $\mathrm{BV}$ & & -108 & & & 133 & & \\
\hline \multirow{7}{*}{$\begin{array}{l}\text { Values and } \\
\text { semantics }\end{array}$} & $\mathrm{Av}$ & 116 & & 139 & & & $-0,233^{*}$ & \\
\hline & $\mathrm{M}$ & $\underline{187}$ & & & & -153 & & 138 \\
\hline & $\mathrm{Al}$ & $-284^{*}$ & & & & & -143 & $-238^{*}$ \\
\hline & $\mathrm{K}$ & & & -12 & & 122 & & 174 \\
\hline & Ind & 104 & & & & & 131 & $22 *$ \\
\hline & $\mathrm{E}$ & & & & & & & -117 \\
\hline & $\mathrm{D}$ & $-239 *$ & -108 & -17 & & $296^{*}$ & -164 & -161 \\
\hline
\end{tabular}

Notes: 1) zeros and commas are omitted; 2 ) italicized level of significance $\mathrm{p} \leq 0,1$; bold $-\mathrm{p} \leq 0.05$; 
underlined $\left.-\mathrm{p} \leq 0.01{ }^{*}-\mathrm{p} \leq 0.001 ; 3\right)$ CSD - cognitive styles of psychological distance; CSP - cognitive styles of psychological position; CBS - cognitive styles of psychological orientation; ROI is a reflective assessment of one's self as a social percept; KEM - inability to manage emotions, dispense them; NP is an inadequate expression of emotions; NNEM - inflexibility, underdevelopment, lack of expression of emotions; DAY - dominance of negative emotions; NZL - reluctance to approach people emotionally; EMB - emotional barriers; EMV - emotional involvement; EMM - emotional modality; EMC emotional orientation; EgMO - selfish motivational orientation; AFMO - Affirmative Motivational Orientation; QMS - situational motivational orientation; PV need for interaction; SS - targeting for social approval; BV - a focus on conflict-free interaction; Av - authoritarian value-meaning orientation; M - manipulative value-meaning orientation; Al - alterocentric value-semantic orientation; Kconformal value-meaning orientation; Ind - indifferent value-semantic orientation; E - equal valuesemantic orientation; D - dialogical value-semantic orientation; 4) P - interrupted empathic interaction; $\mathrm{E}$ is an egocentric empathic interaction; $\mathrm{C}$ - subjectocentric empathic interaction; $\mathrm{H}$ - intentional empathic interaction; $\mathrm{Cn}$ - promoting empathic interaction; $\mathrm{A}$ - altruistic empathic interaction; $\mathrm{D}$ is a dissonant empathic interaction.

The study of correlates of selfcentered empathic interaction revealed the presence of relationships with indicators of cognitive styles of psychological position $(\mathrm{r}=-0,111 ; \mathrm{p} \leq$ $0,1)$, reflective assessment of one's self as a social percept $(r=-0,159 ; p \leq 0,05)$, emotional modality $(\mathrm{r}=0,152 ; \mathrm{p} \leq 0,05)$, emotional immaturity $(\mathrm{r}=0,124 ; \mathrm{p} \leq$ $0,05)$, manifested in inflexibility, underdevelopment, fuzzy emotions $(\mathrm{r}=$ $0,182 ; \mathrm{p} \leq 0,01)$, affiliate $(\mathrm{r}=-0.196 ; \mathrm{p}$ $\leq 0.001)$ motivational orientation, engagement needs $(r=-0.169 ; \mathrm{p} \leq 0.01)$, social approval target $(\mathrm{r}=-0.166$; $\mathrm{p} \leq 0.01)$, mot non-conflict interaction $(\mathrm{r}=$ $-0.108 ; \mathrm{p} \leq 0.1)$ and dialogical valuemeaning orientation $(\mathrm{r}=-0.108 ; \mathrm{p} \leq 0.1)$.

Thus, self-centered empathic interpersonal interaction in adolescence is characterized by a compassionate psychological position, a pessimistic emotional modality, and indifference to others. Realizing this type of interaction, the person does not feel an urgent need to communicate with another, is not guided by the thoughts and needs of the latter, and accordingly, is not concerned with the development of relationships with him. Obviously, having a natural capacity for empathy, when an empathic situation occurs, the empathic process in such people is triggered. However, due to emotional immaturity, which in this case manifests itself in inflexibility, underdevelopment, lack of expression of emotions, it is impossible to activate the mechanism of emotional decentration, without which the transition to more developed types of empathic interpersonal interaction is impossible. At the same time, it should be noted that the vast majority of correlates of egocentric empathic interaction are concentrated in the motivational component. Assume that this type of interaction is more driven by a system of motives that are in the plane "for themselves" or "for others." In the first embodiment, self-centered interaction will be implemented, and in the second, more complex forms of empathic interaction.

When analyzing the correlates of subject-centric empathic interaction, it was found that the latter is in direct statistically significant relation to the cognitive style of psychological distance ( $\mathrm{r}$ $=0,181 ; \mathrm{p} \leq 0,01)$, emotional immaturity $(\mathrm{r}$ $=0,137 ; p \leq 0,05)$, which is caused by the inability to manage emotions, dispense them $(r=0,177 ; p \leq 0,01)$, emotional 
involvement in interaction $(\mathrm{r}=0,143$; $\mathrm{p} \leq 0,05)$, situational motivational orientation $(\mathrm{r}=0,116 ; \mathrm{p} \leq 0,1)$ and dominance setting $(\mathrm{r}=0.139 ; \mathrm{p} \leq 0.05)$. The inversely statistically significant relationship was found with cognitive styles of psychological orientation $(\mathrm{r}=-$ $0.12 ; \mathrm{p} \leq 0.1)$, emotional modality of interaction $(\mathrm{r}=-0.15 ; \mathrm{p} \leq 0.05)$, attitudes toward subjugation of authority $(\mathrm{r}=0.12$; $\mathrm{p} \leq 0.1)$ and dialogical value-meaning orientation $(\mathrm{r}=-0.172 ; \mathrm{p} \leq 0.01)$.

\section{Discussion}

Thus, we see that the subject-centric empathic interaction is characterized by the concentration of its correlates in the emotional component. This is quite natural, because this type of interaction is mainly realized on an emotional level. This is facilitated by a pessimistic emotional modality ("in this situation you will not help anything, you just have to sympathize ...") (Zhuravl'ova, 2007: 42), a high level of emotional involvement in interaction, which can sometimes grow into emotional jam. The latter may be due to the inability of the empathic to manage emotions, dispense them.

In addition, for this type of empathy interaction is characterized by the activation of cognitive processes that provide such mechanisms of empathy as personal and moral reflection, assessment of the situation. Since the process of reflection involves a certain juxtaposition of the society in order to compare its own behavior with its norms, it is quite natural here to have a non-conformist cognitive orientation and cognitive distance from others. The process of assessing the situation also requires some removal.

The functioning of the mechanism for updating the settings at this stage of the empathic process explains the existence of reliable interconnections with the valuesemantic component of interpersonal interaction: in particular, the setting for dominance, the lack of setting for the subjugation of authority and the lack of dialogue. Explaining the positive relationship of subject-centric interaction with a dominance setting is quite difficult. We assume that this setting reflects the willingness of the empathic to be an active participant in this interaction. Without this installation, he would remain a mere spectator who may be worried about the empath, but does not interact with it.

The negative correlation with the attitudes of authority and dialogue is quite clear. Thus, in the first case, the greater the willingness to submit to a reputable Other, the lower will be the concentration on the position of the empath. Dialogical interaction implies the perception of the Other as an equal subject, the creator of one's life. This perception of the Other would require the expectation of some, probably, joint action to resolve the situation, not just sympathy.

Quite unexpected were the results of the search for correlates of intentional empathic interpersonal interaction, as we could not find any.

We assume that the transition from intent to concrete action is governed not so much by the personal characteristics of the empathic, but by situational or objective factors.

In terms of facilitating empathic interpersonal interaction, its correlates are indicators of all components of interpersonal interaction. Yes, this type of empathic interaction correlates positively with cognitive styles of psychological orientation. In particular, facilitative interaction is characterized by a constructive psychological orientation $(r=$ 
$0.24 ; \mathrm{p} \leq 0.001$ ), which provides cognitive attitudes to the mutual satisfaction of the subjects of the interaction according to the situation. That is why the empathic responds to the empathogenic situation in such a way as to help the other and not harm their own interests.

This kind of interaction is impossible with the emotional immaturity of the empathic $(\mathrm{r}=-0.174 ; \mathrm{p} \leq 0.01)$, in particular in such manifestations of the latter as inability to control emotions, dispense them $(\mathrm{r}=-0.134 ; \mathrm{p} \leq 0.05)$, dominance of negative emotions $(\mathrm{r}=-$ 0.145; $\quad \mathrm{p} \leq 0.05), \quad$ inflexibility, underdevelopment, fuzzy emotions, $(\mathrm{r}=-$ $0.184 ; \mathrm{p} \leq 0.01$ ), as evidenced by the negative correlation of the contributing empathic interaction with these indicators of the emotional component. Instead, we found a significant correlation with emotional modality $(r=0.293 ; p \leq 0.001)$, which indicates the tendency of people who implement a facilitating interaction to be optimistic about their life (empathogenic) situation, their willingness to overcome obstacles.

In the motivational component, a positive correlation was found with affiliative motivational orientation $(\mathrm{r}=$ $0.176 ; p \leq 0.01)$, social approval target ( $\mathrm{r}$ $=0.134 ; \mathrm{p} \leq 0.05)$, and compromise interaction $(\mathrm{r}=0.133 ; \mathrm{p} \leq 0,05)$. A negative correlation was also found with selfish motivational orientation $(\mathrm{r}=-$ $0.149 ; \mathrm{p} \leq 0.05$ ). Therefore, the motives for facilitating interaction can be directed at developing interaction with empaths, on positive evaluation of one's own behavior by other participants in the empathogenic situation (including empaths), on reaching a compromise between the needs of empaths and one's own interests. The selfish motivational orientation hinders the realization of this type of empathic interaction.

In the value-semantic sphere of the person realizing the empathetic interaction, a valuable attitude towards the other is revealed. This is evidenced by the presence of a positive correlation with the dialogical $(\mathrm{r}=0.296 ; \mathrm{p} \leq 0.001)$ and conformal $(\mathrm{r}=$ $0.122 ; p \leq 0.1)$ value-meaning orientation and the inverse - with the manipulative $(\mathrm{r}=$ $-0.153 ; p \leq 0.05$ ).

The next stage was devoted to the study of altruistic interpersonal interaction. Because it is the most advanced type of empathic response, and to provide it, the most complex mechanisms of empathy that have a cognitive, emotional, motivational nature are activated, its correlates are indicators of all components of interpersonal interaction. In particular, a significant correlation was found with such indicators of the cognitive component as cognitive styles of psychological distance $(\mathrm{r}=-$ $0.143 ; \mathrm{p} \leq 0.05)$ and directionality $(\mathrm{r}=$ $0.131 ; \mathrm{p} \leq 0.05)$. Therefore, altruistic interaction will be characterized by a cognitive orientation to psychological closeness and a constructive style of interaction development.

The emotional component revealed a significant relationship with optimistic emotional modality $(r=0,184 ; p \leq 0,001)$, emotional involvement $(\mathrm{r}=-0,109$; $\mathrm{p} \leq 0,1)$ and emotional immaturity $(\mathrm{r}=-$ $0,164 ; p \leq 0,01)$. Indeed, to help the Other by risking one's own interests (and sometimes one's own health or even one's life) requires a high level of emotional involvement, for which the fear of the Other, the pity for one, etc., dominates the experience for one's own well-being. At the same time, going for self-sacrifice, according to the law of self-preservation, 
the empathic person simply has to believe in achieving the desired result. Conversely, an individual will not be able to actually contribute to self-harm if he / she is unable to manage his / her emotions, dispense them, does not want to emotionally attach to others, and is not emotionally labile. That is, the emotional immaturity that manifests itself in all sorts of emotional barriers hinders the feeling of the Other and the subsequent emotional attachment.

Regarding the value-semantic component, centering on the Other $(\mathrm{r}=$ $0.24 ; \mathrm{p} \leq 0.001)$ and setting on dialogic interaction are characteristic for the realization of altruistic interpersonal interaction. Instead, authoritarian $(\mathrm{r}=-$ $0.233 ; \mathrm{p} \leq 0.001)$ and indifferent $(\mathrm{r}=-$ $0.142 ; p \leq 0.05)$ values and values impede the realization of this type of empathic interaction. Such a result is quite natural, since self-sacrifice by its very nature presupposes a leveling of one's own interests for the sake of the welfare of the Other. Such an empathic response is only possible if one values and interacts with the Other. Thus, we conclude that altruistic interaction is more likely when the interaction between empath and empath is realized at the relationship level.

As proof of the above thesis is the correlates of the motivational component of interpersonal interaction. These include the need for engagement $(\mathrm{r}=0.207$; $\mathrm{p} \leq 0.01$ ), and the goal of social approval $(r=0.106 ; p \leq 0.1)$. There is no doubt that if we value a person, he is important to us, then we need to be close to that person. In order to satisfy this need, it is necessary that this person also reciprocates. Hence the desire to please the Other, to look good in his eyes.

The highest number of correlates among the diagnosed indicators of interpersonal interaction was found in the study of dissonant interpersonal interaction. This is due to the fact that this type of interaction included all possible forms of anti-empathy, which can be realized at the level of personal-sense and transcendental empathy. Thus, the mechanisms that ensure the functioning of these forms were combined, which prevented the ability to isolate the dominant component of interpersonal interaction. Thus, in the empirical study it was found that the dissonant interaction is characterized by a confronting psychological position, non-conformist cognitive orientation, low level of emotional maturity, manifested in low control of emotions and expression of their emotions, pessimistic emotions, orientation, selfish or marginal motivational orientation. All this is accompanied by the lack of need for interaction and the depreciation of another person.

\section{Conclusion}

The study met the following steps: the first was the diagnosis of empathy of the subjects and the frequency of manifestations of each type of empathy interpersonal interaction was determined; on the second were diagnosed cognitive, emotional, motivational and valuemeaning individual-psychological qualities and features of young people, which are important for the situation of interpersonal interaction; in the third stage, the relationships between each type of empathic interpersonal interaction and the personal indicators of the subjects were determined. For this purpose, the Pearson linear correlation method was used. Analyzing the peculiarities of the interconnections of all kinds of empathic 
"SOCIALIZATION \& HUMAN DEVELOPMENT" INTERNATIONAL JOURNAL

interaction with some of the individualpsychological characteristics of adolescence, we can state:

1. Indifferent empathy interaction is most related to indicators of the valuesemantic component of interpersonal interaction, self-centered - motivational, subject-centered - emotional.

2. Encouraging, altruistic, and dissonant empathic interactions should correlate across all components of interpersonal interaction.

3. Intentional empathic engagement with any of the studied metrics is unrelated.

The raised topic needs further research.

Conflict of interests. There is no real conflict of interests at the time of writing this article or potential conflicts of interest for authors with responsible persons or any other person third parties on the subject matter of the article and related areas of legal research.

Acknowledgments. The study did not receive a grant from any financial agency in state, commercials or the nonprofit sector.

\section{References}

Bratchenko S. L. (1997). Diagnostika lichnostno-razvivajushhegosja

potenciala. Metodicheskoe posobie dlja shkol'nyh psihologov [Diagnostics of personalitydeveloping potential. Methodical manual for school psychologists.]. Pskov. S. 34 -56. [in Russian].

Bulatevich N., Mambetova A. (2018). Psychological peculiarities of parenthood apprehensions of Ukrainians and Crimean Tartars. International Journal of Education \& Development, 1, 13 - 24.

Danyliuk I. V., Kozytska I. V. \& Shykovets S. O. (2018). The cultural syndrome "Individualism collectivism"and its psychological peculiarities including well-being of regional communities representatives in Ukraine. Scientific journal "Fundamental and applied research in practice of leading scientific schools", 30, 6, 55 -61 .

Duhnovskij S. V. (2009). Diagnostika mezhlichnostnyh Psihologicheskij

[Diagnostics otnoshenij. praktikum relationships. interpersonal

Practical Training ] / Duhnovskij S.V. - SPb.: Rech'. 141. [in Russian].

Eliseev O. P. (2001). Praktikum po psihologii lichnosti [Practical work on personality psychology ]. SPb.: Piter. 560. [in Russian].

Zhuravl'ova L. P., Kolomiec' T.V. (2013). Empatijna determinacija kognitivnih stiliv mizhosobistisnoji vzaemodiji u junac'komu vici [The empathic determination of cognitive stiles of inter-personal interaction at the juvenile age ] // Problemi zagal'noji ta pedagogichnoji psihologiii: $\mathrm{Zb}$. nauk. prac' Institutu psihologiji im. G.S. Kostjuka APN Ukrajini, [za red. S. D. Maksimenka]. - K. T. XV, ch. 1. - S. 104 - 112. [in Russian].

Zhuravl'ova L. P. (2007). Psihologija empatiji: Monografija [The psychology of empathy]/Zhuravl'ova L.P. - Zhitomir: Vid-vo ZhDU im. I. Franka. 328. [in Ukrainian].

Fetiskin N. P. Kozlov, V. V. \& Manujlov G. M. (2002). Social'nopsihologicheskaja diagnostika razvitija lichnosti $i$ malyh grupp [The social-psychological diagnostics of development of 
personality and small groups ] / Sost. N.P. Fetiskin, V V. Kozlov, G.M. Manujlov. M.: Izd-vo instituta psihoterapii. 490. [in Russian].

McLaughlin K. A., King K. (2015).

Developmental trajectories of anxiety and depression in early adolescence. J. Abnorm. Child Psychol. $\quad 43$ 311-323. 10.1007/s10802-014-9898-1

Moilanen K. L., Rasmussen K. E., PadillaWalker L. M. (2015). Bidirectional associations between self-regulation and parenting styles in early adolescence. J. Res. Adolesc. 25 246-262. 10.1111/jora.12125

Prokopovych Y. (2017). Psykholohichna kharakterystyka mikrosotsialnykh chynnykiv internet-zalezhnoi povedinky pidlitkiv [Psychological characteristics of microsocial factors of adolescent Internetdependent behavior]. Visnyk Kyivskoho natsionalnoho universytetu imeni Tarasa Shevchenka. Psykholohiia - Bulletin of Taras Shevchenko National University of Kyiv. Psychology, 2, 116 - 120 [in Ukrainian].

Riabchych I. (2018). Psykholohiia obdarovanosti [Psychology of giftedness]. Kyiv: «TsP «KOMPRYNT» [in Ukrainian].

Shykovets S.O., Mambetova A.A. (2018). Psychological features of the representatives' identity in the regional communitiesof Ukraine and Poland. Naukovyi Visnyk Khersonskoho Derzhavnoho Universytetu. Psykholohiia Scientific Bulletin of Kherson State University. Psychology, 3, 1, 142 148.

Tully E. C., Ames A. M., Garcia S. E., Donohue M. R. (2016). Quadratic associations between empathy and depression as moderated by emotion dysregulation. J. Psychol. 15015 35. 10.1080/00223980.2014.992382

Van der Graaff J., Carlo G., Crocetti E., Koot H. M., Branje S. (2018). Prosocial behavior in adolescence: gender differences in development and links with empathy. J. Young people Adolesc. 47 1086-1099. 10.1007/s10964-017-0786-1

Van Lissa C. J., Hawk S. T., Koot H. M., Branje S., Meeus W. H. J. (2017). The cost of empathy: parentadolescent conflict predicts emotion dysregulation for highly empathic young people. Dev. Psychol.53 1722-1737. 10.1037/dev0000361

Vlasova O. I. (2019). Influence of internet dependency on young people selfactualization. Socialization \& Human Development: International Scientific Journal,1, 1, 5-12. 


\title{
"TIME FOR WISDOM" - THE RELATIONSHIP BETWEEN WISDOM AND THE TIME PERSPECTIVE
}

https://doi.org/00.00000/SHDISJ-00-0.0-0000

\author{
Timoszyk-Tomczak Celina, \\ ORCID ID 0000-0002-8314-0476 \\ Szcześniak Małgorzata \\ ORCID ID: 0000-0002-6637-2304
}

\begin{abstract}
Analysing the relationships between wisdom and time is increasingly becoming an important and interesting issue. The purpose of the study is empirical verification of the relationship between wisdom and the five categories of the temporal perspective: the positive past (PP), negative past (NP), hedonistic present (HP), fatalistic present (FP) and the future $(\mathrm{F})$. It has been assumed that wisdom will positively correlate with the combination of three dimensions considered the balanced time perspective (past-positive, present-hedonistic, and future) and negatively correlated with the temporal profile considered less functional (past-negative and present-fatalistic perspective).

The study has been conducted on a group of 279 Polish respondents, including $67 \%$ women, aged 16-28 (M=19.13; $\mathrm{SD}=3.01)$. The group has been composed of secondary school pupils and students. Two research tools were used: The Three-Dimensional Wisdom Scale (3D-WS) by Ardelt (2003), in Polish adaptation by Steuden, Brudek and Izebski (2006) and the Zimbardo Time Perspective Inventory (ZTPI-short version), adapted by Cybis, Rowiński and Przepiórka (2012).

On the basis of the obtained results, it can be assumed that: 1) participants of the study characterised by general wisdom and its cognitive dimension do not focus on the $\mathrm{FP}$ and NP; 2) in case of the reflexive dimension of wisdom, the predictive function is performed by the NP, FP and, to a lesser extent, the PP; 3 ) the only predictors of the affective dimension of wisdom have turned out to be the FP and the F.

The obtained results seem to have the theoretical and empirical justification. Individuals with lower scores on wisdom have expressed aversion to past events and have been convinced that they have no control over the present, and that what is happening is a result of capricious fate. Significant correlations of wisdom concern the negative temporal profile, both in the general dimension of wisdom and in relation to its individual dimensions.
\end{abstract}

Keywords: Time perspectives, Balanced time perspective, Wisdom, Positive past, Negative past, Hedonistic present, Fatalistic present, Future

\section{Introduction}

In recent years, interest in wisdom has increased. On the basis of gerontology and developmental psychology, there have been appearing numerous empirical studies showing the relationship between wisdom and, among other things, the sense of well- being (Ardelt and Edwards, 2016), identity (Bang, 2009; Bang and Zhou, 2014), religiosity and personality (Adamovová, 2013), as well as the post-formal thinking, the complex concept of God and success in school (Benovenli, Fuller, Sinnot, and Waterman, 2011). Researchers have been 
searching for the relationship between wisdom and the sense of happiness and emotional intelligence (Zacher, McKenna and Rooney, 2013) or irrationality (Kardačová, 2010). They point out that wisdom necessitates the integration of emotions and cognition to develop towards self-awareness, self-transcendence and leading people to promote dignified life among themselves and their communities (Ardelt and Ferrari, 2014).

Researchers have verified to what extent wisdom is associated with age (Asandi, Amiri and Molavi, 2015, Cheraghi et al., 2015). They have studied its relationship with maturity and whether wisdom leads to higher level of well-being in late adulthood and a decrease in the level of death fear (Ardelt et al., 2013). The obtained results show that wisdom in older ages increases life satisfaction, both directly and indirectly, through mature personality of the elderly. Moreover, an increase in mature personality traits in women is associated with wisdom (Ardelt, 2006).

Despite growing interest in wisdom, little is known about the relationship between the perception of time and wisdom, and human behaviour is hard to understand without reference to time (Zakay, Ray and Glicksohn, 2014). Subjective time perception has an impact on the basic human processes, including motivation, cognition and emotions. Time provides basis for most behavioural and cognitive processes (Carstensen, 2006). In psychology, interest is primarily aroused by subjective time, which is analysed, among other things, in the context of the time perspective, temporary orientation, and attitude towards time or temporary competences (Block, 1990; Nuttin, 1985; Lens, 2006; Uchnast, 2006). The temporary perspective is a significant part of human space (Timoszyk-Tomczak and Bugajska, 2013) and a dimension that organises human life experiences (Król, Boniecka and Rzepa, 2016). On the other hand, high temporary competence is associated with integration of the past, present and future dimensions, experiencing their continuity, and being open to the present, accepting the past and taking into account the future (Lamparska-Zając, 2013). Webster (2014), the author of an extensive publication on time and wisdom, indicates two ways in which time is inextricably connected with wisdom: the historical time relating to changes in understanding wisdom over the centuries and the developmental (so called ontological) time which is related to the time perspective. Webster was one of the first psychologists to analyse the dynamic relationships between time and wisdom.

It is anticipated that wise people can draw on their own past, use the present and adequately plan the future (Baltes and Staudinger, 2000). For this reason, analysing the relationships between wisdom and time is increasingly becoming an important and interesting issue. Authors of psychological models of wisdom point to the fact (Ardelt, 2003; Baltes and Staudinger, 2000; Webster, 2016) that learning from past experiences is considered an important element of wisdom. In addition, empirical research (Webster, 2016) shows that recalling episodic positive experiences (memories) accompanied by positive anticipation of future events is associated with cohesion. In addition, having a balanced time perspective is a characteristic trait of wisdom (Webster, Bohlmeijer, and Westerhof, 2014). Scheibe, Kunzmann and Baltes (2011) also claim that wisdom is a skill which comprises the past, present and 
"SOCIALIZATION \& HUMAN DEVELOPMENT" INTERNATIONAL JOURNAL

future dimensions as well as the related uncertainties.

\section{Wisdom}

The definition of wisdom itself is not unambiguous and as such it has fascinated researchers, both conceptually and empirically. Attempts at systematising the ways of understanding wisdom show that it can be treated as: a configuration of specific personality traits and personal competences, a positive result of individual development, a complex system of practical knowledge or a process that manifests itself in everyday life (see Steuden, Brudek and Izdebski, 2016, Yang, 2008). Different ways of defining wisdom lead, in consequence, to various methods of its operationalisation and measurement (Ardelt, 2004, 2011; Taylor, Bates and Webster, 2011). Such variety of interpretations suggests a relationship between wisdom and other concepts which are close to it, such as intelligence and spirituality. Research carried out among experts (Jeste et al., 2010) shows that specialists differentiate and differently characterise wisdom. For example, they attribute to it distinctive traits: it is unique to human species, constitutes a form of advanced cognitive and emotional development, constitutes a rare personal quality which can be learned and which increases with age. A wise person is someone who is competent and fulfilled in his/her life, but can also share his/her wisdom and experience with others. This means that a wise person is characterised by concern for others, empathy and reciprocity (Taylor, Bates and Webster, 2011).

Ardelt (2011) bases his ThreeDimensional Wisdom Scale (3D-WS) on the concept of Clayton and Birren (1980) and presents wisdom as a combination of cognitive, reflexive and emotional dimensions of personality. The cognitive dimension is defined as the understanding of life and striving to understand the deeper meaning of the phenomena, in particular those of interpersonal character. This dimension also refers to knowledge and acceptance of positive and negative aspects of human nature, natural boundaries of knowledge as well as the unpredictability and uncertainty of life. The reflexive dimension is defined by Ardelt (2011) as perceiving the phenomena and events from several perspectives, which is associated with self-assessment, self-awareness and gaining insights into oneself. A wise person is able to transcend his/her subjectivity and look at things from many different perspectives. The affective dimension, on the other hand, refers to an approach full of fondness of and love towards others based on emotions and compassion.

Ardelt (2011) assumes that such features as: mature and integrated personality, mental health, autonomy, wellbeing, the sense of happiness and humour are related to wisdom, or are its consequence. The term wisdom used by Webster (2003) refers to wisdom as a multidimensional coherent system of five inter-related factors, such as: experience, emotional regulation, reminiscence/reflectiveness, openness and humour. If these dimensions are combined, then a given person can be considered wise. It follows that wisdom is a complex construct requiring in-depth analyses, but also a reality which cannot be overlooked in search for better understanding of human behaviour.

The purpose of the article is empirical verification of the relationship between wisdom and the five categories of the temporal perspective: the positive past 
"SOCIALIZATION \& HUMAN DEVELOPMENT" INTERNATIONAL JOURNAL

(PP), negative past (NP), hedonistic present (HP), fatalistic present (FP) and the future (F).

\section{Time and time perspective}

Individual's perception of time changes throughout his/her life. This is due to the "multidimensionality of time". It may be differently understood and differently marked and depends on the system of empirical references, in which the duration and sequence of the observed phenomena or events is recognised (Trempała, 2000). The experience of time itself includes three main types of references and the related classes of temporal determinants, such as: neurobiological, psychophysical and also civilisation and cultural ones (Nosal, 2010). Such complexity calls for a justified and ordered method of analysis. For this reason, many researchers attempt to describe subjective time of an individual by means of selected categories. For the purpose of this paper, we will mainly focus on the conception of Zimbardo and Boyd (1999, 2008), who describe their time perspective conception by reference to such time perspective dimensions as: the past, present, and the future.

The time perspective (TP) conception integrates the motivational, emotional, cognitive and social processes (Zimbardo and Boyd, 2015). The TP constitutes a fundamental dimension of psychological time structure, defined by Zimbardo and Boyd $(1999,2008)$ as an unconscious process as a result of which the personal and social experiences of an individual are assigned to specific time categories which help in making them orderly, coherent and meaningful. The researchers conclude that the time perspective is one of the basic processes of individual and social human functioning. It can also be individualised due to individual's predispositions, cultural influences and other modifying interactions. It has a ubiquitous and powerful, but largely unrecognised, influence on many human behaviours (Zimbardo and Boyd, 1999). Studies show that TP has an impact, among other things, on pro-health behaviours and risk (Boyd and Zimbardo, 2005), use of tobacco, alcohol and drugs (Keough, Zimbardo and Boyd, 1999) as well as on risky driving (Zimbardo, Keough and Boyd, 1997). TP dimensions related to the past reflect two orientations: a negative one which is associated with trauma, pain and regret and a positive one which reflects warm and sentimental attitudes towards the past. Dimensions related to the present also indicate two orientations: the hedonistic one that focuses on pleasure with little concern about the future consequences and the fatalistic one revealing a helpless and hopeless attitude towards the future and life. The future TP dimension focuses on the presentation of future consequences, fears, responsibilities and striving for future goals and rewards (Cretu, 2012; Zimnardo and Boyd, 1999).

Zimbardo and Boyd (1999) focus on the balanced time perspective and define it as an "ideal time frame", which, depending on the situation at hand and evaluation of individual and social resources, allow people to flexibly move between the categories - the past, present and the future. Webster (2011) defines the balanced time perspective as a frequent and fairly balanced inclination to think about one's past and future in a positive manner. Each of the respondents also slightly differently operationalises the balanced time perspective. The Zimbardo and Boyd Time Perspective Inventory ZTPI is used to measure the positive and negative past, the 
hedonistic and fatalistic present and the future. A profile with a relatively high scores for the positive past, hedonistic present and the future, and relatively low scores for the negative past and fatalistic present is considered to be a balanced time perspective. Operationalisation of the balanced time perspective, as presented by these authors, can be carried out in at least three ways described by Zhang, Howell and Stolarski (2013).

\section{Research questions and hypotheses}

The purpose of the study is empirical verification of the relationship between wisdom and the five categories of the temporal perspective: the positive past, negative past, hedonistic present, fatalistic present and the future. The theoretical basis of these analyses is a statement of Boniwell and Zimbardo (2004) that the time perspective is the reality that has a real impact on all aspects of human life. In addition, Webster (2016) underlines that people characterised by wisdom can analyse past events, live in the present and plan the future. Wise people can simultaneously learn from past experiences and have an optimistic and expansive future orientation (Webster, Bohlmeijer and Westerhof, 2014). For this reason, it has been assumed (Hypothesis 1) that wisdom will positively correlate with the combination of three dimensions considered the balanced time perspective (past-positive, present-hedonistic, and future) and negatively correlated with the temporal profile considered less functional (past-negative and present-fatalistic perspective). Besides, it has been also assumed that the selected temporal perspectives will perform a predictive function for wisdom (Hypothesis 2).

Methodology
Participants.The study was conducted on a group of 279 Polish respondents, including $67 \%$ women, aged 16-28 $(M=19.13 ; S D=3.01)$. The group has been composed of secondary school pupils and students. The study has been of a group nature and has been conducted by trained interviewers. After obtaining their consent to participate in the study, participants were presented with its goal and brief instructions, then the questionnaire battery has been handed out.

Research tools. Two research tools were used: The Three-Dimensional Wisdom Scale (3D-WS) by Ardelt (2003), in Polish adaptation by Steuden, Brudek and Izebski (2006) and the Zimbardo Time Perspective Inventory (ZTPI-short version), adapted by Cybis, Rowiński and Przepiórka (2012).

Both in the original and in the Polish version, the Three-Dimensional Wisdom Scale consists of 39 statements, to which the respondent responds on a 5-point Likert-type scale, from 1 - I strongly agree to 5 - I strongly disagree. In case of some items, a reverse scoring has been used. In the original version, the scale consists of 3 sub-scales with satisfactory levels of reliability: for the cognitive sub-scale Cronbach's alpha has been $\alpha=0.85$; for the reflexive sub-scale $\alpha=0.71$, and for the affective one $\alpha=0.72$. In the Polish version, the factor analysis has indicated a fourfactor scale structure. The Cronbach's alpha measures of reliability have also proved satisfactory. For the cognitive subscale $\alpha=0.77$, for the affective sub-scale $\alpha=0.64$, while the original reflexive subscale in the Polish version has shown two factors: the self-awareness factor $\alpha=0.73$ and the empathic factor $\alpha=0.72$ (Steuden, Brudek and Izdebski, 2016). 
"SOCIALIZATION \& HUMAN DEVELOPMENT" INTERNATIONAL JOURNAL

In its shortened version, the Zimbardo Time Perspective Inventory (Zimbardo and Boyd,1999) consists of 15 statements, to which the respondent responds on a fivepoint scale, where 1 means "very true", and 5 "very untrue". The questionnaire examines five time perspectives, including two past ones (positive and negative) and two present ones (hedonistic and fatalistic), and the future time perspective. Reliability levels obtained for individual sub-scales are satisfactory: negative past $\alpha=.74$, positive past $\alpha=.51$, hedonistic present $\alpha=$ .63 , fatalistic present $\alpha=.56$, future $\alpha=.71$.

Balanced time perspective:
In addition, deviation from the balanced time perspective has been calculated. The purpose of the evaluation has been to determine whether and in what way a combination of fairly strong retrospective positive time perspective, moderate hedonistic time perspective and moderate prospective perspective, with simultaneously weaker fatalistic and negative perspectives, correlates with general wisdom and its individual dimensions. A formula proposed by Stolarski (Stolarski, Vowinckel, Jankowski, Zajenkowski, 2016) has been used.

$$
\sqrt{(o N P-e N P)^{2}}+(o P P-e P P)^{2}+(o F P-e F P)^{2}+(o H P-e H P)^{2}+(o F-e F)^{2}
$$

Ideal levels for each time perspective have been adopted after an optimum value presented by Zimbardo: 1.95 [oNP], 4.60 [oPP], 1.50 [oFP], 3.90 [oHP], 14.00 [oF]). If the final score is high, it indicates a significant deviation from the balanced time perspective and is considered to be non-adaptive. Low scores are close to an ideal temporary balance.

Statistical data analysis has been carried out by means of IBM SPSS Statistics 20 package. Thanks to the obtained normal distribution of the examined variables, parametric tests, i.e. Student's t test for independent samples, Pearson correlation (r) and regression analysis, was employed.

\section{Results}

Verification of the formed hypotheses has been preceded by a check whether the variable distribution is normal. Because the absolute values for skewness and kurtosis have not exceeded the arbitrary value equal $+/-1$ for the former and $+/-2$ for the latter, the distributions have been considered to be close to distribution configuration of a normal character. Then Pearson correlation (r) and stepwise regression analysis were carried out. Upon consultation with authors of the Polish adaptation, a decision has been made to use in the study original dimensions of wisdom, i.e. the sub-scales differentiated by Ardelt (2011), due to greater consistency in the obtained results. Statistical analysis of the Pearson correlation (r) has shown that in this group of respondents there is a strong negative correlation between wisdom and the twotime dimensions: negative past and fatalistic present, and a weak positive correlation between wisdom and the present (Table 1). Moderate or strong negative correlations emerge between all dimensions of wisdom and also the negative past and fatalistic present. Moderate, weak and at the trend level positive correlations emerge between the reflexive dimension of wisdom and the positive past and the future and between the 
"SOCIALIZATION \& HUMAN DEVELOPMENT" INTERNATIONAL JOURNAL

affective dimension of wisdom and the future. There is no correlation between wisdom and hedonistic present. In addition, negative correlation has been noted between deviation from the balanced perspective.

Table 1. Pearson correlations ( $r)$ for the variables: wisdom and time perspective $(N=279)$

\begin{tabular}{|l|l|l|l|l|l|l|}
\hline Variables & \multicolumn{1}{|c|}{ PP } & \multicolumn{1}{c|}{ NP } & HP & \multicolumn{1}{c|}{ FP } & \multicolumn{1}{|c|}{ F } & BTP \\
\hline Global wisdom & $.107^{\mathrm{t}}$ & $-.401^{* *}$ & -.003 & $-.403^{* *}$ & $.099^{\mathrm{t}}$ & $-.461^{* *}$ \\
\hline Cognitive wisdom & -.042 & $-.322^{* *}$ & -.006 & $-.392^{* *}$ & -.015 & $-.328^{* *}$ \\
\hline Reflexive wisdom & $.192^{* *}$ & $-.453^{* *}$ & $.044^{* *}$ & $-.291^{* *}$ & $.107^{\mathrm{t}}$ & $-.468^{* *}$ \\
\hline Affective wisdom & $.099^{\mathrm{t}}$ & $-.155^{* *}$ & -.021 & $-.264^{* *}$ & $.157^{* *}$ & $-.285^{* *}$ \\
\hline
\end{tabular}

Key: PP positive past, NP negative past, HP hedonistic present, FP fatalistic present, F future, BTP balanced time perspective; ${ }^{\mathrm{t}}$ correlation at the trend level

The obtained results have partially confirmed the first hypothesis showing a negative correlation between wisdom and the less functional time profile. They have not, however, confirmed any correlation with the temporal profile of a balanced character, i.e. the positive past, hedonistic present or the future. There have only appeared a positive correlation with the past, which is however weak and not related to the other elements of the profile characteristic for the balanced time perspective.

During the next stage, consisting in verification of the second hypothesis, it has been noted, as a result of the stepwise analysis of regression, that both time dimensions correlated with wisdom have turned out to be its predictors: the fatalistic present and the negative past (Table 2). The indicated temporary categories account for $27 \%$ of wisdom variance, while the strength of their mutual relationship is moderate. On the basis of the obtained results, it can be assumed that participants of the study characterised by wisdom do not focus on the fatalistic present and do not recall or remember negative events from their past (Table 2).

Table 2. Results of stepwise regression for the dependent variable: global wisdom $(\mathrm{N}=\mathbf{2 7 9})$

\begin{tabular}{|l|l|l|l|l|l|}
\hline \multirow{3}{*}{$\begin{array}{c}\text { Independent } \\
\text { variable }\end{array}$} & \multicolumn{2}{l}{$\begin{array}{l}\mathbf{R}=. \mathbf{5 2 0} ; \mathbf{R}^{\mathbf{2}}=\mathbf{. 2 7 1} ; \boldsymbol{\Delta} \mathbf{R}^{\mathbf{2}}=\mathbf{. 2 6 5} \\
\end{array}$} & \multicolumn{1}{|c|}{$\boldsymbol{B}(2.272)=50.062, \mathrm{p}<.000$}
\end{tabular}

The purpose of subsequent tests has been to carry out a stepwise regression wisdom in order to verify which temporary analysis for individual dimensions of dimensions of wisdom (Tables 3, 4 and 5).

Table 3. Results of stepwise regression for the dependent variable: the cognitive dimension of wisdom $(N=279)$

\begin{tabular}{|l|l|l|c|c|c|}
\hline \multirow{2}{*}{$\begin{array}{l}\text { Independent } \\
\text { variable }\end{array}$} & \multicolumn{2}{|l|}{$\mathbf{R}=. \mathbf{4 6 9} ; \mathbf{R}^{2}=.220 ; \Delta \mathbf{R}^{2}=.214$} \\
& $\mathrm{~F}(2.275)=38.402, \mathrm{p}<.000$
\end{tabular}


"SOCIALIZATION \& HUMAN DEVELOPMENT" INTERNATIONAL JOURNAL

\begin{tabular}{|l|l|l|l|l|l|}
\hline FP & -3.093 & .487 & -.346 & -6.347 & .001 \\
\hline NP & -1.768 & .379 & -.255 & -4.667 & .001 \\
\hline
\end{tabular}

Predictors of the cognitive treated wisdom. The cognitive dimension dimension of wisdom have turned out to be of wisdom is only slightly better explained fatalistic present and negative past, which by the fatalistic present, while the strength account for nearly $22 \%$ of variance. The of both explanatory variables is moderate. result is similar to the result for globally

Table 4. Results of stepwise regression for the dependent variable:

the reflexive dimension of wisdom $(\mathrm{N}=279)$

\begin{tabular}{|c|c|c|c|c|c|}
\hline \multirow[t]{2}{*}{$\begin{array}{l}\text { Independent } \\
\text { variable }\end{array}$} & \multicolumn{5}{|c|}{$\begin{array}{l}\mathbf{R}=\mathbf{. 5 1 8} ; \mathbf{R}^{\mathbf{2}}=\mathbf{. 2 6 8} ; \mathbf{\Delta R}^{\mathbf{2}}=\mathbf{. 2 6 0} \\
\mathrm{F}(3.276)=33.356, p<.000\end{array}$} \\
\hline & $B$ & $S E$ & Beta $\beta$ & $t$ & $p$ \\
\hline Constant & 47.542 & 2.157 & & 22.038 & .001 \\
\hline NP & -2.435 & .336 & -.386 & -7.239 & .001 \\
\hline $\mathbf{F P}$ & -1.838 & .430 & -.226 & -4.275 & .001 \\
\hline $\mathbf{P P}$ & 1.296 & .450 & .151 & 2.879 & .004 \\
\hline
\end{tabular}

In case of the reflexive dimension of wisdom, the stepwise regression analysis model shows that the predictive function for this variable is performed by the negative past, fatalistic present and, to a lesser extent, the positive future. The model accounts for approximately $27 \%$ of variance. This means that the high scores on the wisdom scale in the reflexive dimension are also associated with less focus on negative past events, less fatalistic view of the present as well as with focus on positive past experiences.

Table 5. Results of stepwise regression for the dependent variable: the affective dimension of wisdom $(\mathrm{N}=279)$

\begin{tabular}{|l|l|l|l|l|c|}
\hline \multirow{2}{*}{$\begin{array}{l}\text { Independent } \\
\text { variable }\end{array}$} & \multicolumn{2}{l}{\begin{tabular}{l}
$\mathbf{R}=. \mathbf{3 0 7} ; \mathbf{R}^{\mathbf{2}}=\mathbf{. 0 9 4} ; \boldsymbol{\Delta} \mathbf{R}^{\mathbf{2}}=\mathbf{. 0 8 7}$ \\
\cline { 2 - 6 }
\end{tabular}} & \multicolumn{1}{|c}{$\boldsymbol{B}(2.273)=14.059, \mathrm{p}<.000$}
\end{tabular}

The last of the carried out analyses shows that the affective dimension of wisdom is to the least extent explained by the temporary dimensions, which account for only $9 \%$. The only predictors of this dimension have turned out to be the fatalistic present and the future. This may suggest that people with a developed affective dimension of wisdom, thus more focussed on relationships, empathy and compassion, also demonstrate a less fatalistic attitude towards the present and are positively oriented towards the future.

\section{Discussion}

The obtained results, indicating the correlation between wisdom and the negative temporal profile, seem to have the theoretical and empirical justification. Zimbardo and Boyd (2008) identify the negative past and fatalistic present as time 
dimensions that are most detrimental to human functioning. In turn, Reznitskaya and Sternberg (2007) believe that a wise person takes a long-range view and perceives his or her life and the surrounding reality in a long-term time perspective. The memory of the past is a key element of wisdom, which means that wise people can draw conclusions from their own experiences and distance themselves from them. The balanced time perspective accounts for $7.1 \%$ and $12.5 \%$ of the variance in ego-integrity and wisdom (Webster, 2016). On the other hand, in this study we found that individuals with lower scores on wisdom have expressed aversion to past events and have been convinced that they have no control over the present, and that what is happening is a result of capricious fate.

What is more, the results are consistent with the analyses carried out by Ardelt (2011), who points out that traumatic events and thinking about the past may be necessary, but are not enough to shape wisdom. Without adequate assessment, auto-reflextion and insight into oneself, negative and difficult life experiences may rather lead to depression, anxiety or distress. It is natural that almost all of us would like to be happy and satisfied with life individuals, that is: individuals who do not care for their fate and do not experience any losses associated with ageing (Ardelt and Oh, 2010). Usually, we try to be happier in the future than in the past or the present. We cannot, however, escape the fact that our lives are dynamic and unpredictable. At any moment, we may experience a life crisis or difficulties. Perhaps the inability to functionally reinterpret past events and conviction that we are unable to influence the reality is an important aspect which negatively correlates with wisdom.

Although few positive correlations and several trends have been noted between individual dimensions of wisdom and the functional time perspectives, deviation from the balanced time perspective has correlated negatively with global wisdom and all its dimensions. In this sense, our study has confirmed the results obtained by Webster, Bohlmeijer and Westerhof (2014). Their studies have shown that the balanced time perspective correlates with a better frame of mind and wisdom across the entire adult age range. Skilful use of one's own past, memory of those periods when we coped with problems, developed and spent time with our nearest and dearest, can improve the mental, emotional and social well-being and have a positive impact on mental health. Similarly, imagining future goals, dreams of successes and imagining future exciting achievements can be beneficial for our mental health. Researchers apply the same conclusions to relationships between the balanced time perspective and wisdom. Memories can regulate emotions, support more effective actions and beneficially build the strength. In addition, wise people appreciate motivation for setting long-term goals. Of importance is, however, not only a separate memory of the past and the vision of the future, but a combination of these two elements.

Significant correlations of wisdom concern the negative temporal profile, both in the general dimension of wisdom and in relation to its individual dimensions. Persons with lower scores on the wisdom scale also more intently focus on the negative past experiences and have a more fatalistic view of the present day. Tulving (2002) points out that we drag behind the 
entire past, but what our memory allows to the present, what we have access to, includes either accidental memories or what supplements our current situation. This means that individuals with fatalistic orientation more easily focus on past failures. This could mean that such people do not experience the positive effect associated with our autobiographical memory (Maruszewski, 2011), which is associated with low level of wisdom. Such results may be due to cultural differences, current socio-economic conditions or an effect of ambiguous definition of the balanced time perspective. Some studies show for example a decrease in positive emotions and an increase in negative emotions with age, in particular in respondents from Post-Communist Western European Countries (Pinquart, 2001). Perhaps under Polish cultural conditions, with pronounced negative asymmetry (Czapiński, 1988), more important than a positive temporal profile for the development of wisdom is lack of focus on negative aspects of our own past and being less fatalistic in thinking about the present and the future. This implies the need for broader studies, including both the Polish and intercultural aspects.

Looking at the additionally obtained results of regression analysis relating to individual dimensions of wisdom, it should be noted that in the reflexive dimension of wisdom, an important predictor, in addition to the negative temporary profile, is the positive past. Persons with higher scores on the reflexive wisdom scale are less fatalistic, have a less negative and more positive view of their own future. The result corresponds to the results obtained in studies relating to wisdom and meaning, which show that wisdom is positively correlated with drawing conclusions from difficult experiences (Webster, Weststrate, Ferrari, Munroe, and Pierce, 2017), and that there is a relationship between wisdom and the method of recalling life experiences (Webster, 2014). Wisdom in the reflexive dimension is not only conducive to reducing negative memories of the past, but also to forming a more positive view of the future.

The emerging weak significant correlations between wisdom and the future perspective show, in more precise analyses, that the dimension of wisdom, which the fatalistic present and the future account for, is the affective dimension. This means that persons who are more focussed on positive attitude towards others, based on empathy and compassion, also demonstrate a less fatalistic view of the present and think more of the future. It can be assumed that wisdom, in particular in its affective dimension, is associated with the future aspect. This is confirmed in the studies by Ardelt and Edwards (2016), which show that the correlation between wisdom and well-being is partially mediated by purpose in life, both directly and indirectly, by mastery. In other studies, such attributes of the elderly as wisdom, having a goal in life or spirituality are predictors of subjective well-being and death fear (Ardelt et al., 2013). Wise people feel better in their own company, have higher self-esteem and expect positive experiences in the future (Webster et al., 2017). The examples cited indicate the need for more detailed studies that would show what role the future perspective plays in wisdom.

The results presented have some limitations, the sample group of respondents are adults, but from different stages of life, which may not indicate the existing differences, e.g. in early, middle and late adulthood. Another question is the 
"SOCIALIZATION \& HUMAN DEVELOPMENT" INTERNATIONAL JOURNAL

conceptualisation of wisdom and the time perspective which are differently defined and operationalised (Ardelt, 2011; Taylor, Bates and Webster, 2011; Webster, 2011; Zimbardo and Boyd, 1999).

\section{Conclusion}

The results obtained indicate correlations between wisdom and the negative temporal profile. Individuals with lower scores on wisdom have expressed aversion to past events and have been convinced that they have no control over the present. Few positive correlations and several trends have been noted between individual dimensions of wisdom and the functional time perspectives, deviation from the balanced time perspective has correlated negatively with global wisdom and all its dimensions. Significant correlations of wisdom concern the negative temporal profile, both in the general dimension of wisdom and in relation to its individual dimensions. Persons with lower scores on the wisdom scale also more intently focus on the negative past experiences and have a more fatalistic view of the present day. In the reflexive dimension of wisdom, an important predictor, in addition to the negative temporary profile, is the positive past. Persons with higher scores on the reflexive wisdom scale are less fatalistic, have a less negative and more positive view of their own future. Wisdom in the reflexive dimension is not only conducive to reducing negative memories of the past, but also to forming a more positive view of the future. The future study directions could include persons at various stages of adulthood, take into account sex, and could be carried out with the use of various measurement tools. It would be advisable to include intercultural comparisons.
Previous studies show differences in the level of wisdom depending on age (Ardelt, 2006; Asandi, Amiri, Molavi, 2015) and also depending on sex (Cheraghi et al., 2015) and culture (Bang and Zhou, 2014; $\mathrm{Hu}, 2017)$.

\section{References}

Adamovová, L. (2013). Wise religiosity: The relationship between religiosity and wisdom moderated by personality traits. Studia Psychologica, 55, 181-194.

Ardelt, M. (1995). Wisdom in the later years: A life course approach to successful aging. Dissertation Abstracts International Section A: Humanities and Social Sciences, 55(\&-A): 2160.

Ardelt, M. (2003). Empirical assessment of a three-dimensional wisdom scale. Research and Aging, 25, 275-324.

Ardelt, M. (2004). Wisdom as expert knowledge system: A critical review of a contemporary operationalization of an ancient concept. Human Development, 47, 257-85.

Ardelt, M. (2006). Set in Their Ways? Personality Stability and Change in Women and Men across Forty Years. In: J. A. Arlsdale (Eds.), Advances in social psychology research (pp. 3756). Hauppauge, NY, US: Nova Science Publishers.

Ardelt, M. (2011). The Measurement of Wisdom: A Commentary on Taylor, Bates, and Webster's Comparison of the SAWS and 3D-WS. Experimental Aging Research, 37, 241-255.

Ardelt, M., \& Edwards, C. A. (2016). Wisdom at the End of Life: An Analysis of Mediating and Moderating Relations Between Wisdom and Subjective Well-Being. 
Journals of Gerontology Series B: Psychological Sciences \& Social Sciences, 71, 502-513.

Ardelt, M., \& Ferrari, M. (2014). Wisdom and emotions. In: P. Verhaeghen \& C. Hertzog (Eds), The Oxford handbook of emotion, social cognition, and problem solving in adulthood (pp. 256-272). New York, US: Oxford University Press.

Ardelt, M., \& Oh, H. (2010). Wisdom: Definition, assessment, and relation to successful cognitive and emotional aging. In: C. A. Depp \& D. V. Jeste (Eds.), Successful cognitive and emotional aging (pp.87-113). Arlington, VA, US: American Psychiatric Publishing.

Ardelt, M., Landes, S. D., Gerlach, K. R., \& Fox, L. P. (2013) Rediscovering internal strengths of the aged: The beneficial impact of wisdom, mastery, purpose in life, and spirituality on aging well. In: J. D. Sinnott (Ed.), Positive psychology: Advances in understanding adult motivation (pp. 97-119). New York, NY, US: Springer Science + Business Media.

Asandi, S., Amiri, S., \& Molavi, H. (2015). The development of wisdom from adolescence to erderly. Journal of Psychology, 19, 37-52.

Baltes, P. B., \& Staudinger, U. M. (2000). Wisdom. A metaheuristic (pragmatic) to orchestrate mind and virtue toward excellence. American Psychologist, 55, 122-36.

Bang, H. (2009). The relationship of wisdom and ego-identity for Korean and American adolescents. Dissertation Abstracts International Section A: Humanities and Social Sciences, 70(5-A): 1552.
Bang, H., \& Zhou, Y. (2014). The function of wisdom dimensions in ego identity development among Chinese university students. International Journal of Psychology, 49, 434-455.

Benovenli, L., Fuller, E., Sinnott, J., \& Waterman, S. (2011). Three applications of the theory of postformal thought: Wisdom, concepts of God, and success in college. Research in the Social Scientific Study of Religion, 22, 141154.

Block, R. A. (1990). Cognitive models of psychological of time. Hillsdale, NJ: Erlbaum.

Boniwell, I., \& Zimbardo, P. G. (2004). Balancing one's time perspective in pursuit of optimal functioning. In: P. A. Linley \& S. Joseph (Eds.), Positive psychology in practice (pp.165-180). Hoboken, NJ, US: Wiley.

Boyd, J. N., \& Zimbardo, P. G. (2005). Time Perspective, Health, and Risk Taking. In: A. Strathman \& J. Joireman (Eds), Understanding behavior in the context of time: Theory, research, and application (pp.85-107). Mahwah, NJ, US: Lawrence Erlbaum Associates Publishers.

Carstensen, L. L. (2006). The Influence of a Sense of Time on Human Development. Science, 312, 19131915.

Cheraghi, F., Kadivar, P., Ardelt, M., Asgari, A., and Farzad, V. (2015). Gender as a Moderator of the Relation Between Age Cohort and Three-Dimensional Wisdom in Iranian Culture. International 
"SOCIALIZATION \& HUMAN DEVELOPMENT" INTERNATIONAL JOURNAL

Journal of Aging \& Human Development, 81, 3-26.

Cretu, R. Z. (2012). The Relation of Human

Factor of Values with Time

Perspective. Procedia - Social and

Behavioral Sciences, 78, 758-762.

Cybis, N., Rowiński, T., and Przepiórka, A. (2012). Development of the Polish version of Zimbardo Time Perspective Inventory. Paper presented at Ist International Conference on Time Perspective, Coimbra, Portugal.

Czapiński, J. (1988). Wartościowanie. Efekt negatywności (O naturze realizmu). Wrocław: Ossolineum.

$\mathrm{Hu}$, C. (2017). Measurement of wisdom among mainland Chinese. Dissertation Abstracts International: Section B: The Sciences and Engineering, 77(8B)(E).

Jeste, D. V., Ardelt, M., Blazer, D., Kraemer, H. C., Vaillant, G., \& Meeks, T. W. (2010). Expert Consensus on Characteristics of Wisdom: A Delphi Method Study. Gerontologist, 50, 668-680.

Kardačová, J. (2010). Wisdom and irrationality: Probe into mutual relationships. Studia Psychologica, 52, 339-346.

Keough, K. A., Zimbardo, P. G., \& Boyd, J. N. (1999). Who's smoking, drinking, and using drugs? Time perspective as a predictor of substance use. Basic and Applied Social Psychology, 21, 149-164.

Król, J., Boniecka, K., and Rzepa, T. (2016) Perspektywa czasowa w okresie późnej dorosłości i jej znaczenie dla satysfakcji z życia uczestniczek Uniwersytetu trzeciego Wieku - doniesienia wstępne.
Polskie Forum Psychologiczne, 21, 589-601.

Lamparska-Zając, L. (2013) Temporalny wymiar osobowości. Panorama stanowisk. Studia Humanistyczne AGH, 12, 79-93.

Lens, W. (2006). Future Time Perspective: A Psychological Approach. In: Z. Uchnast (Ed.), Psychology of Time (pp.51-64). Lublin: Wydawnictwo KUL.

Maruszewski, T. (2011). Czy wspomnienia bledną afektywnie? In: D. Doliński \& W. Błaszczak (Ed.), Dynamika emocji. Teoria $i$ praktyka (pp.88111). Warszawa: Wydawnictwo Naukowe.

Nosal, C. S. (2010). Czas w umyśle człowieka. Struktura przestrzeni temporalnej. In: S. Bedyńska \& G. Sędek (Eds.), Życie na czas: Perspektywy badawcze postrzegania czasu (pp.365-397). Warszawa: Wydawnictwo Naukowe PWN.

Nuttin, J. (1985). Future time perspective and motivation. Leuven-Hillsdale: Leuven University Press-Erlbaum.

Pinquart, M. (2001). Age differences in perceived positive affect, negative affect, and affect balance in middle and old age. Journal and Happiness Studies, 2, 375-405.

Reznitskaya, A. \& Sternberg, R. J. (2004). Teaching students to make wise judgments: The ,teaching for wisdom" program. In: P. A. Linley \& S. Joseph (Eds.), Positive psychology in practice (pp. 181-196). New York, NY, US: Wiley.

Scheibe, S., Kunzmann, U., \& Baltes, B. (2011). New territories of positive life-span development: Wisdom and life longings. In: C. R. Snyder \& S. J. Lopez (Eds.), Handbook of 
"SOCIALIZATION \& HUMAN DEVELOPMENT" INTERNATIONAL JOURNAL

Positive Psychology (pp. 171-183).

New York, NY, US: Oxford University Press.

Steuden, S., Brudka, P., \& Izdebski, P. (2016). A Polish adaptation of Monika Ardelt Three-Dimensional Wisdom Scale (3D-WS). Roczniki Psychologiczne, 19, 769-792.

Taylor, M., Bates, G., \& Webster, J. D. (2011). Comparing the Psychometric Properties of Two Measures of Wisdom: Predicting Forgiveness and Psychological Well-Being with the Self-Assessed Wisdom Scale (SAWS) and the Three-Dimensional Wisdom Scale (3D-WS). Experimental Aging Research, 37, 129-141.

Timoszyk-Tomczak, C. \& Bugajska, B. (2013). Satysfakcja z życia a perspektywa przyszłościowa w starości. Opuscula Sociologica, 2, 83-95.

Trempała, J. (2000). Modele rozwoju psychicznego: czas $i$ zmiana. Bydgoszcz: $\quad$ Wydawnictwo Akademii Bydgoskiej.

Tulving, E. (2002). Episodic Memory: From Mind to Brain. Annual Review of Psychology, 53, 1-25.

Uchnast, Z. (2006). Temporal Competencies-Concepts and the Method of Measurement. In: Z. Uchnast (Eds.), Psychology of time. Theoretical and Empirical Approaches (pp.143-162). Lublin: Wydawnictwo KUL.

Webster, J. D. (2003). An Exploratory Analysis of a Self-Assessed Wisdom Scale. Journal of Adult Development, 10, 13-22.

Webster, J. D. (2011). A new measure of time perspective: Initial psychometric findings for the
Balanced Time Perspective Scale (BTPS). Canadian Journal of Behavioural Science / Revue canadienne des sciences $d u$ comportement, 43, 111-118.

Webster, J. D. (2014). Time to be wise. Temporal perspective and wisdom. Enschede, the Netherlands: University of Twente.

Webster, J. D. (2016). Reminiscence and Anticipation: How a Balanced Time Perspective Predicts Psychological Strengths. The International Journal and Life Review, 3, 1-7.

Webster, J. D., Bohlmeijer, E. T., \& Westerhof, G. J. (2014). Time to flourish: the relationship of temporal perspective to well-being and wisdom across adulthood. Aging \& Mental Health, 18, 1046-1056.

Webster, J. D., \& Weststrate, N. M., Ferrari, M., Munroe, M., \& Pierce, T. W. (2017). Wisdom and Meaning in Emerging Adulthood. Emerging Adulthood, 20, 1-19.

Yang, S. Y. (2008). A process view of wisdom. Journal of Adult Development, 15, 62-75.

Zacher, H., McKenna, B., \& Rooney, D. (2013). Effects of self-reported wisdom on happiness: Not much more than emotional intelligence? Journal of Happiness Studies, 14, 1697-1716.

Zając-Lamparska, L. (2013). Czas teraźniejszy w funkcjonowaniu człowieka. Perspektywa psychologiczna. Szkice Humanistyczne, 31, 215-225.

Zakay, D., Ray, M., \& Glicksohn, J. (2014). Psychological time as information: the case of boredom. Frontiers in Psychology, 5: 1-5. 
Zhang, J. W., Howell, R. T., \& Stolarski, M. (2013). Comparing Three Methods to Measure a Balanced Time Perspective: The Relationship Between a Balanced Time Perspective and Subjective WellBeing. Journal of Happiness Studies, 14, 169-184.

Zimbardo, P., \& Boyd, J. N. (1999). Putting time in perspective: A valid, reliable, individual-differences metric. Journal of Personality and Social Psychology, 17, 1271-1288.

Zimbardo, P. G., \& Boyd, J. N. (2008). The Time Paradox: The New Psychology of Time That Will Change Your Life.
New York, US: Free Press.

Zimbardo, P. G., \& Boyd, J. N. (2015). Putting time in perspective: A valid, reliable individual-differences metric. In: M. Stolarski, N. Fieulaine, W. van Beek (Eds), Time perspective theory: Review, research and application. Essays in honor of Philip G. Zimbardo (pp.17-55). Cham, Switzerland: Springer International Publishing.

Zimbardo, P. G., Keough, K. A., \& Boyd, J. N. (1997). Present time perspective as a predictor of risky driving. Personality and Individual Differences, 23, 1007-1023. 
"SOCIALIZATION \& HUMAN DEVELOPMENT" INTERNATIONAL JOURNAL

\title{
THE EFFECTIVENESS OF THE PSYCHOLOGICAL SUPPORT \\ PROGRAM OF THE PERSONAL-PROFESSIONAL GROWTH OF THE STATE EMPLOYMENT SERVICE OF UKRAINE PERSONNEL RESERVE
}

https://doi.org/00.00000/SHDISJ-00-0.0-0000

\author{
Vlasova O., \\ https://orcid.org/0000-0002-9894-0038 \\ Kalenichenko K., \\ https://orcid.org/0000-0002-9517-3902
}

\begin{abstract}
Modern methods and technologies of personality development in the context of professional activity have been described and analyzed in this article, in particular, the effectiveness of the program of psychological support of its development in the format of webinars has been discussed. In the hard and unstable time of today: economic changes, social transformations and epidemic threat, the problem of organizing and realization of productive distance learning becomes especially relevant for the professional activity of psychologists, instructors of higher education institutions, preparation of the personnel reserve of the State Employment Service of Ukraine (SESU). The psychological support program has been worked out for the SESU staff reserve and realized on the basis of the SESU staff training institute. Its preparation and realization are focused on the dynamics of such indicators of reservists as motivation of achievement, orientation in time, plasticity of behavior, management of emotions, activity, creativity. The purpose of the article is to prove the effectiveness of the webinar program as a method of remote psychological support of the reservists' development.

Methods which have been used in the program elaboration: five-factor personal questionnaire (Khromov A. B. 2000); self-actualization test - CAT (Aleshina Iu.E., 2003); test for the diagnosis of achievement motivation (A. Mehrabian, 2002); self-development readiness test by V.L Pavlov; test for emotional consciousness (Vlasova O. I., Berezyuk, 2015). The effectiveness of the psychological support program was tested using the Gsigns criterion and the t-test for dependent samples. Among the methods of psychological support, special attention is paid to: narratives, methods of educational coaching, narration and symbol drama.

According to the results of the study (106 people), distance learning in the format of webinars has proved to be an effective method of maintaining the staff reserve of the SESU. The implementation of this program and testing its effectiveness have shown positive, statistically significant results.
\end{abstract}

Keywords: personal development, distance learning, psychological support, coaching.

\section{Introduction}

One of the priorities of modern Ukraine as a European state is the desire of its citizens to build a modern, democratic society focused on the interests of people, open to creative innovations and aimed at development. This is a society in which everyone can realize his/her inalienable rights to qualitative education and medical service, deserving work and pensionary 
guarantee, to have free access to objective information, modern knowledge, to use social and personal development.

Such guidelines are due to the process of intellectualization, which actively penetrates the lives of Ukrainians, saturated with its mental activity. In this regard, trends in the labor market, requirements for candidates. In addition to the standard intellectual potential of any (professional) activity are changed, they become important: scientific, creative and innovative components, which, in their turn, requires additional analysis and rethinking of the necessary competences and personal qualities of office employees, especially their personnel reserve (Kalenychenko K. M., 2018). The task of specialists in the public employment service is not only to fulfill certain functional responsibilities, but also to provide appropriate social services that must meet the conditions of modern production and management. A specialist of SESU must have modern information technology; be able to adapt to the rapid changes of the labor market, to perceive and introduce new forms of work; be ready to make his|her own decision to achieve the strategic goals of the organization (Dmytriiev-Zarudenko, 2010; 26-30). It determines the actuality of the study of the factors which determine the selfdevelopment of the reservist's personality over the course of his|her life and the modern tools of psychological and pedagogical support of a such process.

The purpose of the article is to demonstrate the effectiveness of the dictance learning program of psychological support of personal growth of the personnel reserve of the SESU by interpreting the results of a formative psychological- pedagogical experiment of teaching such a contingent of persons.

\section{Theoretical background}

The problems of formation and professional development of personnel potential are the subject of scientific exploration of national and foreign researchers, in particular, Karamushka L M. (2009), Shchkin G. V. (1994), J. Hadsen and J. Reich J. (2015), KhomenkoSemenova L O. (2015), Pritchard J. (2014), Romanov N. M. (2010) and others. An analysis of the scientific and methodological literature on training and development of the personnel reserve convincingly proves that the emphasis in modern professional adult learning shifts from the formation of professional skills to the development of their social and personal skills (soft skils), such as: change management, leadership, emotional intelligence and creativity. In particular, James Pritchard (2014), while studying at the University of Oxford at Brooks University, examines "coaching of reasonable actions" of US civil servants, uses group coaching, mentoring, and even yoga philosophy and practice to develop participant leadership. The practice developed by J. Pritchard is understood by the author as an innovative approach to USSL self-service (CSL) and has methodological support in the form of a workbook for specialists in such a "teamwork for primary and collaborative care" (Oxford University Press, USA, 2014). By 2014, the practice of organizing such work was mastered by more than 470000 US civil servants.

In the analysis of modern technologies for the development of the personality of a specialist of the State Employment Service, the achievements of distant education deserve special attention, methodical 
supply of which is presented by audio- and videotransmissions, E-Learning, webinars etc. In modern Ukraine, distance education is actively developing thanks to the computerization of the population and the development of IT technologies. The experience of using it captures the undoubted benefits of such training. First of all, it is an expansion of the number of people who are able to receive training, namely persons with special needs. In addition, it makes it possible to train its users in remote areas of the country. In these circumstances, communication with teachers can be accomplished by a variety of ways, both online and off-line, and teacher and student contacts are more frequent, faster, and more effective via chat and email than in-person or correspondence since they do not require spatial integration of both sides of learning. Third, the use of remote technologies is effective for organizing an individual approach to educational activities. A student himself/herself chooses the pace of learning and at the same time can promptly receive teachers' answers to the questions that arise during the learning activity. In the fourth place, the development and implementation of the curriculum as a series of webinars solves the problem of accessibility in a single time dimension of educational services to users of educational services from different regions of the country and even the world.

The problems of distance education are integrated at the pole of the psychological readiness of the population to use such educational programs. So, from 2012 to 2014, Harvard University researchers J. Hadsen and J. Reich conducted research among MOOC (Massive Open Online Courses), online platforms with free educational courses.
The main advantage of these platforms is their accessibility. Users only need Internet access to master the knowledge content they host. The developers of the free learning project believed that such services would help democratize knowledge and allow different sections of the population to close the educational gap. The researchers checked 68 online courses from Harvard University and MIT. Over the course of the project, 164198 Americans aged 13-69 passed. It turned out that the most common category of MEP users is university students, usually from wealthy families. Also, online courses are extremely popular with those who involved in science and technology. But people from poor regions or low levels of education were in the minority: according to the study, they simply had no need to acquire such knowledge. (John D. Hansen, Justin Reich, 2015).

Thus, despite the obvious advantages, the use of distance learning has real limitations, which overcoming it requires educators and developers to create programs of appropriate psychological and pedagogical support for the audience of users. In view of this conclusion, the objectives of our study included: 1) to develop the form and content of the program aimed at developing the personality of the reservist of the SSSU; 2) describe the procedure for on-line testing of such a program; 3) to present statistics in favor of the effectiveness of the developed psychological support program.

\section{Methodology}

The study involved 106 personnel reserve staff of the State Employment Service of Ukraine (SESU), who underwent refresher training at the Institute of Training of SBSU of the city of Kiev in the semester period from 01.09.2018 to 
"SOCIALIZATION \& HUMAN DEVELOPMENT" INTERNATIONAL JOURNAL

31.12.2018. Among them, there were 98 women and 8 men between the ages of 19 and $43(\mathrm{M}=30.89 ; \mathrm{SD}=7.74) .85 \%$ of these persons do not have higher education (see Table 1), with $62 \%$ working in the PESU, 26\% having part-time employment and $11 \%$ not working (see Table 2).

Table 1. The education of respondents

\begin{tabular}{|l|c|c|c|c|}
\hline & Frequency & Percentage & $\begin{array}{c}\text { Valid } \\
\text { percentage }\end{array}$ & $\begin{array}{c}\text { Accumulated } \\
\text { percentage }\end{array}$ \\
\hline accountant economist & 8 & 7,5 & 7,5 & 7,5 \\
\hline master of manicure & 8 & 7,5 & 7,5 & 15,1 \\
\hline without specialization & 76 & 71,7 & 71,7 & 86,8 \\
\hline travel agent & 8 & 7,5 & 7,5 & 94,3 \\
\hline florist & 4 & 3,8 & 3,8 & 98,1 \\
\hline photographer & 2 & 1,9 & 1,9 & 100,0 \\
\hline Total & $\mathbf{1 0 6}$ & $\mathbf{1 0 0 , 0}$ & $\mathbf{1 0 0 , 0}$ & \\
\hline
\end{tabular}

Table 2. Employment of respondents

\begin{tabular}{|c|c|c|c|}
\hline \multicolumn{2}{|c|}{} & Frequency & Percentage \\
\hline \multirow{4}{*}{ Valid } & does not work & 12 & 11,3 \\
\cline { 2 - 4 } & works & 66 & 62,3 \\
\cline { 2 - 4 } & part-time & 28 & 26,4 \\
\cline { 2 - 4 } & Total & $\mathbf{1 0 6}$ & $\mathbf{1 0 0 , 0}$ \\
\hline
\end{tabular}

The composition of the sample is due to the peculiarity of a complete set of research groups that were previously selected as a promising staff reserve of such service. The initial ascertainment of participants was conducted during the training sessions, correctivedevelopmental work and their final psychological examination - during the intersession period.

In order to develop a program of psychological support, the research participants were offered a battery of tests to determine the dimensions of their personality and motivation to achieve, which included: A five-factor personal questionnaire (Khromov, 2000); Selfactualization test - SAT (YU.E. Aleshyna); Diagnostic test for the achievement motivation by A. Mehrabian (Fetyskyn, 2002; 72-76); V.L Pavlov's "Readiness for Self-Development" test to determine the type of readiness (Piekhota, 2009; 30-33); Emotional Self-Test for the diagnosis of peculiarities of the development of intrapersonal emotional intelligence of personality (Vlasova, Berezyuk, 2015). The author also has developed a questionnaire focused on identifying the objective characteristics of the subjects' life (age, gender, place of residence, education, profession, previous and current professional activity, etc.).

The effectiveness of the psychological support program was tested using the Gmarks criterion and the t-Student test for the dependent samples. All mathematical operations were performed in the IBM SPSS Statistics computer program (version 20.0).

\section{Results}

In forming the components of the program of psychological support, we relied on the results of an empirical study 
"SOCIALIZATION \& HUMAN DEVELOPMENT" INTERNATIONAL JOURNAL

that describes the personality of the employee of the State Employment Service of Ukraine and demonstrates the connection of personal dimensions of civil servants with their need to develop themselves. In the article "Factors affecting the personal development of employees of the State Employment Service of Ukraine" (Kalenichenko K.M., Vlasova O.I., 2019) the experience of such a study, which, in particular, revealed low and average indicators of this category of employees on the following scales: motivation achievements, time orientation, creativity, plasticity, empathy, emotion management is described in detail. The applied correlation analysis has showed a positive relationship between the motivation data of the employees of the SESU and the development of their need to know themselves $(\mathrm{R}=47, \mathrm{p}<01)$. In their turn, respondents' desire to know themselves was related to such dimensions of their personality as creativity $\mathrm{R}=55$, plasticity of behavior $\mathrm{R}=64$, time orientation $\mathrm{R}=66$, responsibility for their emotions $R=42$, emotion management $\mathrm{R}=66$, empathy $\mathrm{R}=$ 48 , plasticity $R=68$, curiosity $R=49$, prudence $\mathrm{R}=62$, responsibility $\mathrm{R}=53$, and activity $\mathrm{R}=54$. The identified dependencies were put in the basis for the development of the Program of psychological support for personal and professional development of the personnel reserve of the State Employment Service of Ukraine. Its implementation was carried out in the format of a webinar cycle. The tasks of using the program became the need to: 1) increase the level of development of the psychological qualities of the participants, which contribute to their personal growth (motivation to achieve, orientation in time, creativity, plasticity, empathy, management of emotions); 2) to create educational conditions for the transition of the reservist's personality to self-development and self-improvement in the conditions of organized educational process.

The implementation of the program includes three content blocks: Personal development of the head; Time management technologies; Individual Development Plan (KM Kalenichenko, 2018). Its structure is described by the following topics: Goal setting; Fundamentals of time management and project planning; Leadership as the personal development of a leader; Development of emotional intelligence and creativity; Change management technologies; Creating an individual development plan (see Table 3). Each block provides self-study tasks (for which a list of recommended literature is provided). The total duration of the distance learning course is five weeks (based on 2 webinars per week). During the course of the webinars, three basic functions of participants' training were realized through the help of special interactive techniques in the structure of each block: informationcognitive, correction-developmental and. control and diagnostic. Among the leading methods of the program there were minilectures, coaching techniques, narrative method, techniques of production situation analysis, group symbolism and others. 
"SOCIALIZATION \& HUMAN DEVELOPMENT" INTERNATIONAL JOURNAL

Table 3. Structure of the program of psychological support of the personnel reserve of the SESU

\begin{tabular}{|c|c|c|c|c|}
\hline № & $\begin{array}{l}\text { Stages of the } \\
\text { forming } \\
\text { experiment }\end{array}$ & Block & Webinar & Tasks \\
\hline 1 & Preparatory & & 1 lesson & $\begin{array}{l}\text { Acquaintance with the group, } \\
\text { organizational issues, class time and } \\
\text { course program. }\end{array}$ \\
\hline 2 & Main & $\begin{array}{l}\text { Time } \\
\text { management } \\
\text { technologies }\end{array}$ & $\begin{array}{l}\text { Goal setting } \\
(2 \text { lessons })+\text { self- } \\
\text { study }\end{array}$ & $\begin{array}{l}\text { Increasing the competence of } \\
\text { participants in the topic, forming their } \\
\text { motivation for self-development, } \\
\text { their self-exploration with the help of } \\
\text { the technique symboldrama } \\
\text { "Mountain Motive". }\end{array}$ \\
\hline 3 & & & $\begin{array}{l}\text { Time management } \\
\text { and project } \\
\text { planning } \\
(2 \text { lessons })+\text { self- } \\
\text { study }\end{array}$ & $\begin{array}{l}\text { The feedback is about the drawings } \\
\text { and the narrative of the students. } \\
\text { Increasing your own competence in } \\
\text { the subject. consolidating knowledge } \\
\text { by developing your own project plan. }\end{array}$ \\
\hline 4 & & $\begin{array}{l}\text { Personal } \\
\text { development of } \\
\text { the head }\end{array}$ & $\begin{array}{l}\text { Role of emotional } \\
\text { intelligence } \\
(2 \text { lessons })+\text { self- } \\
\text { preparation }\end{array}$ & $\begin{array}{l}\text { Feedback on organizing your own } \\
\text { reservist projects. Increasing your } \\
\text { own competence in the subject. } \\
\text { understanding your own emotions. } \\
\text { Passing a self-test to determine } \\
\text { leadership style. }\end{array}$ \\
\hline 5 & & & $\begin{array}{l}\text { Creativity } \\
\text { Development } \\
(1 \text { lesson }) \\
\end{array}$ & $\begin{array}{l}\text { Increasing your own competence in } \\
\text { the topic, developing the reservist's } \\
\text { creativity. Reflection. }\end{array}$ \\
\hline 6 & & & $\begin{array}{l}\text { Change } \\
\text { management } \\
\text { technologies } \\
(2 \text { lessons })+\text { self- } \\
\text { study }\end{array}$ & $\begin{array}{l}\text { Increase your own competence in the } \\
\text { topic. Mastering future managers with } \\
\text { methods of diagnosis and self- } \\
\text { diagnosis of psychological factors } \\
\text { that influence the features of change } \\
\text { management in the organization. }\end{array}$ \\
\hline 7 & & $\begin{array}{l}\text { Individual } \\
\text { development } \\
\text { plan }\end{array}$ & $\begin{array}{l}\text { Creating a } \\
\text { personal } \\
\text { development plan } \\
(2 \text { lessons })+\text { self- } \\
\text { study }\end{array}$ & $\begin{array}{l}\text { Development of an individual } \\
\text { reservist development plan. } \\
\text { Development of an individual } \\
\text { development plan for future reservist } \\
\text { subordinates. Finalization of } \\
\text { development plans, Summary of work } \\
\text { and individual control. }\end{array}$ \\
\hline 8 & Finishing & & 1 lesson & $\begin{array}{l}\text { Summarizing, conducting the second } \\
\text { diagnostic slice, summarizing the } \\
\text { results. }\end{array}$ \\
\hline
\end{tabular}

In developing the program of to such aspects of the organization of its psychological support of training of the realization as: constant support of personnel reserve of the State Employment motivation to the training of participants, Service of Ukraine, we have paid attention availability of materials and training 
"SOCIALIZATION \& HUMAN DEVELOPMENT" INTERNATIONAL JOURNAL

facilities (both for students and for teachers), balance between theoretical and practical tasks, an opportunity for participants of the program to learn without breaking from the main activity, and at an individual pace and using modern techniques. For the purpose of optimal information development by participants, the duration of one webinar did not exceed 60 minutes. At the end of each lesson, the materials remained available for reviewing.

At the final stage of implementation of the program of psychological support for the development of the staff reserve of the SESU, in order to identify the individual changes of participants, they were retested on the scales: need for self-knowledge, motivation to achieve, empathy, managing their emotions, orientation in time, creativity and plasticity of behavior.

Comparative analysis of the results of diagnostic sections before and after the forming experiment showed the presence of statistically significant differences in the performance of reservists according to the $\mathrm{G}$ - criterion. The critical values of the criterion $G$ for the statistical significance levels are $p \leq 0.05$ and $p \leq 0.01$. As can be seen from table 4 , the statistical significance between the scores of all involved in the diagnosis of scales before and after the participants of the distance learning program $p<0.01$. Also, the $Z$ value is normalized and associated with a significance level of $p=0.000$. Since the significance level is less than 0.01 , we can be confident in the statistical significance of the differences between the indicators before and after the program. To account for the differences obtained between the diagnostic sections before and after the forming experiment, the t-Student criterion for the dependent samples was selected. It allows to compare the averages of two measurements of the same trait for the same sample.

Table 4. The Indicators of the significance of the differences before and after the escort program

\begin{tabular}{|l|l|r|r|r|r|r|r|}
\hline $\begin{array}{l}\text { Determinants of } \\
\text { personal growth } \\
\text { before and after } \\
\text { the support } \\
\text { program }\end{array}$ & WKM & $\begin{array}{c}\text { Achievement } \\
\text { motivation }\end{array}$ & Empathy & $\begin{array}{c}\text { Emotion } \\
\text { Management }\end{array}$ & $\begin{array}{c}\text { Time } \\
\text { Orienta } \\
\text { tion }\end{array}$ & $\begin{array}{c}\text { Creati } \\
\text { vity }\end{array}$ & $\begin{array}{c}\text { Flexibility } \\
\text { behavior }\end{array}$ \\
\hline$Z$ & $-8,125$ & $-8,002$ & $-4,101$ & $-9,900$ & $-10,100$ & $-8,267$ & $-9,592$ \\
\hline $\begin{array}{l}\text { Significance of } \\
\text { differences (P) }\end{array}$ & 0,000 & 0,000 & 0,000 & 0,000 & 0,000 & 0,000 & 0,000 \\
\hline $\begin{array}{l}\text { Note: WKM =I want to know myself } \\
\mathbf{p}<\mathbf{0 , 0 1}\end{array}$
\end{tabular}

The data in Table 5 show that the average values of the individuals we had studied after completing the distance

learning program increased on almost all selected scales. 
"SOCIALIZATION \& HUMAN DEVELOPMENT" INTERNATIONAL JOURNAL

Table 5 .The Indicators of personal development of a SSSU reservist before and after escort

\begin{tabular}{|l|c|c|c|c|}
\hline Determinants of personal growth & $\begin{array}{c}\text { Average } \\
\text { Points } \\
\text { to }\end{array}$ & $\begin{array}{c}\text { Average } \\
\text { Points } \\
\text { After }\end{array}$ & $\begin{array}{c}\text { Standard } \\
\text { Deviation } \\
\text { to }\end{array}$ & $\begin{array}{c}\text { Standard } \\
\text { Deviation after }\end{array}$ \\
\hline WKM & 2,7925 & 3,6038 & 0,92290 & 0,81275 \\
\hline Achievement motivation & 93,3679 & 106,7170 & 21,11119 & 22,55945 \\
\hline Empathy & 2,8868 & 3,1887 & 1,26732 & 0,97700 \\
\hline Emotion Management & 2,8679 & 4,5094 & 1,10476 & 1,04422 \\
\hline Creativity & 41,0377 & 44,3962 & 8,25420 & 6,76501 \\
\hline Time Orientation & 38,0943 & 46,0189 & 4,36987 & 4,75491 \\
\hline Flexibility behavior & 7,9623 & 9,5472 & 1,92193 & 2,15200 \\
\hline $\begin{array}{l}\text { Note: WKM =I want to know myself } \\
\text { p< } \mathbf{0 , 0 1}\end{array}$
\end{tabular}

The indicators of the positive dynamics of reservists on the scale of achievement motivation (106.7170 vs. $93.3679=12$ points) have been particularly different. The time orientation scale has showed high differences $(8$ points $=$ 46.0189 versus 38.0943). The average results of the growth of indicators which have been obtained by us on the scales of creativity are (by 3,3 points $=$ from 41,0377 to 44,3962), The average low increase of the results of the program is fixed for the scales of emotion management (1,64 points $=4,5094$ against 2,8679 ) and plasticity of participants' behavior (1.5849 points = 9.5472 vs. 7.9623$)$. The lowest increase in the number of reservists was indicated by the empathy scale (3.1887 versus $2.8868=$ 0.3019 units), which is known to have predominantly individual-genetic determination of manifestations.

\section{Discussion}

As a matter of discussion, it should be noted that the executed research has demonstrated the effectiveness of on-line use of some modern technologies and methods of professional development and psychological support of personal growth of employees of SESU.
In the process of designing a program to support the development of personnel reserve, we actively used the techniques of psychological support of future managers, highlighted in the monographic study by Karamushka L. M., Moskalov M.V. (2011), who have reasonably demonstrated the ability to develop the psychological readiness of such professionals for leadership by preparing them to manage change in the organization. The analysis of production situations, group discussions and brainstorming, role-playing and business games used by researchers for this purpose were adapted in our work for use in webinar mode.

As an important resource in the preparation of the distance learning program it should also be considered coaching technology, which has proved to be particularly productive for raising the self-organization and self-regulation of educational and professional activities of the personnel reserve representatives. As in the studies of S.M. Romanova (2010), Yu.V. Nikonenko (2012), L. KhomenkoSemenova (2015) we have adopted the four-stage GROW coaching model proposed by J. Whitmore (2003) as a 
methodological basis for the development of our program. The four symbols that make up the name of this model correspond to the first letters of the words indicating the steps in the client's problem decision with the coach. The first stage "the goal" involves defining the goals and objectives of solving the problem; - the second stage of "reality" - defining the state of the problem, identifying the resources, knowledge needed to solve it; - the third stage of "option" - the search for possible ways to solve the problem, the choice of the most optimal; - the fourth stage of "will" application of selected strategies and their testing in action. In our case of implementation of the tested distance program, the letters of its name indicate the corresponding stages of the on-line discussion. Through the use of such a logic of organizing the virtual communication of the participants of the program intensified the formation of their appropriate skills of productive self-organization of their own communication and activity, which testified to the final analysis of their reflexive feedback.

The results of the initial ascertainment section of the study have showed low indicators of the temporality of the reserve staff of the State Employment Service of Ukraine as its participants, the lack of a well-developed mechanism of personal time experience. As a methodical tool for solving such a problem, the method of narrative has been used in the work, and its application is a consistent description of the person's life in a given time interval (Chepelev N.V. et al., 2013). The choice of such a psychotechnical instrument, which has been shown by the statistical calculations presented above, has contributed to a significant increase of participants' indicators on the time orientation scale $(8$ points $=46.0189$ versus 38.0943). On the other hand, Gone J.P., Miller P.J., Rappaport J. (1999), revealing the potential of using narrative practice, consider that its use not only enhances human competence over time, but also plays a large role in the construction and representation of his/her identity (including also his/her cultural identity). According to scholars, in many of the personal narratives they have identified as "cultural identity narratives", narrators always maintain tensions between the individual and the sociocultural environment. Thus, such narratives, among other things, provide a unique opportunity for the researcher and the authors of the texts to explore their conscious, reflexive self-construction, taking into account the fullest extent of the personality's relationship with the culture, and thus to make apparent for the sake of exploring what actually determines the person's behavior (Gone JP et al., 1999). Taking into account given in our study the complexity, informational content and simplicity of the narrative method application, it is recommended for more extensive utilization in on-line psychological support programs for adult learning related to the solving problems of the methodological support of their personal growth.

We also have come into collision with some technical difficulties related to the quality of communication services when implementing the psychological support program for the personnel reserve of the SESU. Interruptions in Internet connection in some cities of residence of program participants were compensated by webinar entries. In addition, not all students in the study groups joined the classes in a timely manner, including important reasons, but due to the availability of webinar records, 
they were able to view them at a convenient time, perform the necessary independent tasks and thus to ensure a more complete training in the program and the following webinars.

\section{Conclusion}

One of the conditions for the successful realization of the task of development of the personality of the reservist of the State Employment Service of Ukraine is his / her qualified psychological support in order to form the desire of such a specialist for constant personal self-improvement throughout his/her professional activity. The presented research has shown that the program of psychological support of the personnel reserve of the SESU, due to the complex approach of the authors to its design and implementation and the interested attitude of the participants to participation in it, allows to create both external and internal conditions for self-development of the personality of the employee-reservist of the SESU.

According to the research, the main substantive characteristics of actualization and self-development of the future manager's personality are: its directed expansion of cognitive ideas about themselves, increasing motivation of achievement, emotional intelligence, gaining positive experience in the development of time orientation and goal setting, plasticity of their own behavior. Such components of psychological support, being included in the appropriate training program of the reserve staff of SESU, determine the orientation and dynamics of future managers of employment services, contribute to the maturity of those professionally important personal mechanisms, the use of which enables a person to transform him- or herself, organize independed activity for future self-perfection.

Implementation of the developed program and verification of its effectiveness have shown positive statistically significant results, which allow its use in further work. Distance learning in the form of webinars has proved to be an effective didactic form of organization of psychological support in professional adult education. In terms of planning for further research, attention should be drawn to the limitations of the program application of psychological support of the personnel reserve of the State Employment Service of Ukraine. In particular, further optimization requires methodological support aimed at developing participants in psychological training of empathy, emotion management and plasticity of behavior.

\section{References}

Aleshina Iu.E., Gozman L.Ia., Zagika M.V., Kroz M.V. (2003) Samoaktualizatsionnyi test (CAT) [Self-actualization test (SAT)]. «Psikhologiia. Perm» nauchnopoznavatelnyi zhurnal dlia psikhologov i pedagogov. Retrieved from: http://www.psyperm.narod.ru/T40.htm (accessed 23 March 2020). [in Russian]

Dmytriiev-Zarudenko V.V. (2010) Moduli kompetentnosti v praktytsi diialnosti derzhavnoi sluzhby zainiatosti. [Models of competence in the practice of state employment service]. Rynok pratsi ta zainiatist naselennia. Sotsioloho psykholohichni aspekty pratsi ta zainiatosti. no. 3, 26-30. [in Ukrainian]

Fetyskyn N. P., Kozlov V. V., Manuilov H. M. (2002) Sotsyalnopsykholohycheskaia dyahnostyka 
"SOCIALIZATION \& HUMAN DEVELOPMENT" INTERNATIONAL JOURNAL

razvytyia lychnosty y malukh hrupp [Socio-psychological diagnosis of the development of personality and small groups] (pp. 72-76). Moscow: Ynstytuta Psykhoterapyy. [in Russian]

Gone J.P., Miller P.J., Rappaport J. (1999) Conceptual self as normatively oriented: the suitability of past personal narrative for the study of cultural identity. Culture and Psychology. 5(4), 371-398.

John D. Hansen, Justin Reich (2015) Democratizing education? Examining access and usage patterns in massive open online courses. Science. Vol. 350, Issue 6265, 1245 1248. Retrieved from: 10.1126/science.aab3782 (accessed 28 March 2020).

Kalenychenko K. M. (2018) Intelektualizatsiia pratsi, yak psykholohichna peredumova osobystisnoho rozvytku osib, shcho perenavchaiutsia u Derzhavnii sluzhbi zainiatosti [Labor intellectualization as a psychological precondition for personal development of trained persons in the State Employment Service]. Naukovyi visnyk Khersonskoho derzhavnoho universytetu. Seriia «Psykholohichni nauky», vol. 2, no. 1, 31-45. Retrieved from: http://pj.kherson.ua/file/2018/psychology 01/ ukr/part 2/7.pdf (accessed 24 March 2020). [in Ukrainian]

Kalenychenko K. M. (2018) Pobudova prohramy psykholohichnoho suprovodu pratsivnykiv Derzhavnoi sluzhby zainiatosti Ukrainy [Designing a program of psychological support for employees of the State Employment Service of
Ukraine]. Zbirnyk naukovykh prats «Teoriia i praktyka suchasnoi psykholohii», Klasychnyi pryvitnyi universytet, no. 4, 133-138. Retrieved from: http://www.tpspjournal.kpu.zp.ua/archive/4 2018/26.pdf (accessed 25 March 2020). [in Ukrainian]

Karamushka L.M., Moskalov M.V. (2011) Psykholohichni umovy pidhotovky maibutnikh menedzheriv do upravlinnia zminamy $v$ orhanizatsii : Monohrafiia. [Psychological conditions of preparation of future managers for change management in the organization: Monograph.] (pp. 109-149). Kyiv : «Prosvita». Retrieved from: http://elibrary.kubg.edu.ua/id/eprint/11567/ 1/Moskalyov Monografiya.pdf (accessed 18 March 2020) [in Ukrainian]

Khomenko-Semenova L. O. (2015) Kouchynh yak efektyvna tekhnolohiia formuvannia uspishnoho studenta. [Coaching as an effective technology for forming a successful student]. Visnyk Natsionalnoho aviatsiinoho universytetu. Seriia: Pedahohika, Psykholohiia. no. 7, 130-134. [in Ukrainian]

Khromov A.B. (2000) Piatyfaktornui oprosnyk lychnosty: Uchebnometodycheskoe posobye [FiveFactor Personality Questionnaire: A Training Manual]. Kurhan: Kurhanskoho hos. Unyversyteta. [in Russian]

Nykonenko Yu. V. Stanovlennia sotsialnykh zdibnostei u studentiv z funktsionalnymy obmezhenniamy [Developing social abilities in students with functional limitations]. 
(PhD Thesis), Kyiv: DVNZ "Un-t menedzh. osvity". [in Ukrainian]

Piekhota O.M. (2009) Indyvidualnist uchytelia. Teoriia $i$ praktyka [The personality of the teacher. Theory and Practice] (pp. 30-33). Mykolaiv: TOV Firma "Ilion". [in Russian]

Pritchard, J. (2014) Coaching and Mentoring in the Civil Service. Journal Bespoke Executive Coaching. 3 (6), 126 - 130. Retrieved from: http://www.ridlerandco.com/executivecoaching/coaching-and-mentoring-in-thecivil-service/ (accessed 20 March 2020)

Romanova S. M. (2010) Kouchinh yak nova tekhnolohiia $v$ profesiinii osviti [Coaching as a new technology in vocational training]. Nats. aviats. untu. Seriia: Pedahohika. Psykholohiia. no. 3, 83-86. [in Ukrainian]

Thorpe S., Clifford J. (2003) Coaching Handbook: An Action Kit for
Trainers and Managers (p. 67). London: Cogan Page

Vlasova O. I., Kalenichenko K. M. (2019)

The personality traits of employee of State employment service of Ukraine that affect their desire to selfdevelopment and the motivation of achievement. New stages of development of modern science in Ukraine and EU countries: monograph / edited by authors. 6th ed. (pp. 373-393) Riga, Latvia: Baltija Publishing. Retrieved from: http://www.baltijapublishing.lv/download/allscience-3/all-science_part_6.pdf (accessed 25 March 2020).

\section{Acknowledgment}

The study was conducted on the basis of the Institute of Training of the State Employment Service of Ukraine in the period from 01.09 .2018 to 31.12 .2018 academic year. 


\section{THE FEATURES OF ADOLESCENTS'S PERCEPTIONS ABOUT PARENTHOOD}

https://doi.org/00.00000/SHDISJ-00-0.0-0000

Yablonska Tetiana,
ORCID ID: 0000-0001-7272-9691
Bulatevych Nataliya,
ORCID ID: $0000-0002-2971-8740$
Maksymchuk Daria,
ORCID ID:0000-0001-5359-7849

Abstract

The relevance of the study of the parenthood perceptions of modern adolescents is determined by decreasing level of paternity readiness among modern youth. The aim of the study is to investigate the features of adolescents' parenthood apprehensions.

The study involved 63 teenagers (37 boys and 26 girls) aged 15 to 17 years. Adolescents' parenthood perceptions were studied with the help of «Ideas of Ideal parenthood» (R.Ovcharova, Yu.Degtyaryova), as well as with the method of «Composition about parenthood»(O.Karabanova, A.Shvedovskaya, modification by S.Abdullina). Such methods as the descriptive statistics, correlation analysis, Student's ttest were used for data analyses.

Parenthood perceptions are considered as an indicative basis for future parenthood readiness. The content and hierarchy of different components of these apprehensions are defined, such as: cognitive, emotional and behavioral.

The content of adolescents' parenthood apprehensions were revealed, including the image of the future child, the image of relationships in the future family, the idea of himself/herself as a parent. In particular, adolescents' perceptions about themselves as future parents were found to be the least represented in the descriptions of the subjects; they are often associated with ambivalent feelings.

Significant differences in the content of adolescents' parenthood apprehensions about ideal parenting were found. Their structure depends on gender: girls' perceptions are wide enough and mostly they are positively emotionally colored, the majority of the boys' perceptions are not formed and often they have neutral, negative or ambivalent emotional coloring. Gender differences in the structure and level of components of parenthood perceptions manifest themselves in the significantly higher level of girls' behavioral and emotional components, as well as in the greater interconnection of the different components of boys' parenthood perceptions.

Keywords: parenthood, parenthood apprehensions, image of future family.

\section{Introduction}

Nowadays the Institute of Family is undergoing changes that some scientists call the crisis of the family, others - its transformation. These processes are particularly noticeable in contemporary
Ukrainian society, burdened by the complex socio-political and economic situation (Yablonska, Bulatevych, \& Mambetova, 2019). First of all, the ordinary families feel the consequences of this situation, in which the family 
"SOCIALIZATION \& HUMAN DEVELOPMENT" INTERNATIONAL JOURNAL

relationship and the upbringing system are broken.

Changes that take place in the family also cause the transformation of ideas about paternity, the emergence of a variety of forms. Along with the fact that the birth of children is a significant human value, in modern world there are a number of unfavorable trends. Thus, statistics shows an increase in cases of deviant paternity, the emergence of orphanage while there are parents (Abdullina, 2018; Zakharova, 2017; Ovcharova, 2005). In general, there is a trend of delaying the birth of a child, paternity is becoming more "late". The reasons for this are the priorities of career development and self-realization, a stable hedonistic orientation of the individual (the desire to enjoy life before raising children), etc. There is the fact that more and more often, after the birth of the child, parents try to distance themselves from the independent realization of parental functions and hand over their children into the hands of helpers. Increasingly, there are couples who, for various reasons, consciously decide to be childless (the socalled "child free") (Zakharova, 2017; Lindsey S., Strutzenberg A., \& Strutzenberg C., 2019).

Studies in this field (Zakharova, 2017; Meshcheriakova, 2002; Ovcharova, 2005; Yablonska, Bulatevych, \& Mambetova, 2019) show a decrease in paternity readiness among modern youth, a decrease in intergenerational interactions in the exercise of parental functions, increasing anxiety associated with ideas about parenthood. Therefore, studying of the peculiarities of ideas of modern children, adolescents and young people about parenthood is relevant and timely.
Purpose of the study - to investigate the features of adolescents' ideas about parenthood.

Research methodology and organization. The study involved 63 adolescents ( 37 boys and 26 girls) between the ages of 15 and 17, students of the 10th and 11th grades of secondary schools in Kyiv.

Adolescents' perceptions of paternity were explored using R. Ovcharova's and Y.Degtyaryova's «Idea of Ideal Parenthood», which is a variant of semantic differential developed on the basis of content analysis of compositions about paternity. The technique includes 54 pairs of qualities, each of which is rated on a 7point scale. In the structure of ideas about paternity, R. Ovcharova distinguishes cognitive, emotional and behavioral components, each of which is calculated in total using 16 pairs of qualities (Ovcharova, 2005).

In addition, the respondents wrote the composition about the future parenthood (author's modification of the method "Parent's composition" by A. Karabanova, A. Shvedovskaya) by S. Abdullina (Abdullina, 2018). The respondents were given blank with unfinished sentences and it was suggested to complete them with the most appropriate phrase or several phrases. The respondent can write whatever he wants, or what he considers important and necessary. The respondent's answers are divided into three meaningful blocks after analyzing the method "Future Parenthood": "The image of the future child", "The image of the relationship in the future family", "Me as a father/mother".

Descriptive statistics, correlation analysis, Student's t-distribution were used for data processing. 
"SOCIALIZATION \& HUMAN DEVELOPMENT" INTERNATIONAL JOURNAL

\section{Theoretical background}

The works on the ontogeny of the parental sphere of the person, note that psychological readiness for paternity goes through a long period of formation through the formation of ideas about paternity, starting from preschool age (Meshcheriakova, 2002; Filippova, 2002; Chan, \& Tam, 2016) Perceptions of parenthood are studied as an indicative basis for future parental readiness (Abdullina, 2018; Zakharova, 2017). The components of the idea of paternity are distinguished in a number of works, such as: value-semantic (sense of parenthood and place in the system of values of personality), cognitive (image of the future child and himself as parents), emotional (emotional attitude to oneself in the parental role) and behavioral (child care skills) (Ovcharova, 2005; Pavlova, 2012).

\section{Results}

An analysis of the results of the «Idea on Ideal Parenthood» methodology showed that the expressiveness of each component of the conception of girls and boys is different. Table 1 provides descriptive statistics for the sample as a whole and separately for the boys and girls groups.

Table 1.The components' expressiveness of ideas about ideal parenthood in adolescent groups $(\mathrm{N}=63)$

\begin{tabular}{|c|c|c|c|c|c|c|}
\hline \multirow{2}{*}{$\begin{array}{c}\text { The } \\
\text { components of } \\
\text { ideas }\end{array}$} & \multicolumn{2}{|c|}{$\begin{array}{c}\text { Boys } \\
\mathbf{N = 3 7 )}\end{array}$} & \multicolumn{2}{c|}{$\begin{array}{c}\text { Girls } \\
(\mathbf{N = 2 6})\end{array}$} & \multicolumn{2}{c|}{$\begin{array}{c}\text { In general, on a sample } \\
\mathbf{( N = 6 3 )}\end{array}$} \\
\cline { 2 - 7 } & Average & $\begin{array}{c}\text { Standard } \\
\text { deviation }\end{array}$ & Average & $\begin{array}{c}\text { Standard } \\
\text { deviation }\end{array}$ & Average & $\begin{array}{c}\text { Standard } \\
\text { deviation }\end{array}$ \\
\hline Cognitive & 11,0 & 12,80 & 16,08 & 7,50 & 13,1 & 11,15 \\
\hline Emotional & 12,08 & 8,38 & 15,96 & 4,86 & 13,7 & 7,35 \\
\hline Behavioral & 14,70 & 9,85 & 41,0 & 21,65 & 17,6 & 9,77 \\
\hline
\end{tabular}

The analysis of girls 'and boys' perceptions about ideal parenthood revealed the similarity in their hierarchy as the components of perceptions were expressed. The behavioral component of apprehensions about ideal parenthood is more expressed; it includes ideas about parents' skills in caring for, supporting, bringing up and teaching a child. In a girls' sample it is followed by a cognitive, then emotional component with the same degree of expression. Instead, boys have emotional component in the second place and cognitive one in the third place. The emotional component includes indicators that describe the subjective experiences of the person in the parental role, parental feelings, and attitudes towards the child, which is demonstrated through the palette of emotions and emotional states. The cognitive component encompasses the perceptions of being father/mother, child's image, parental functions, and more. The dominance of the behavioral component of perceptions may indicate either a greater awareness of adolescents in what the ideal father/mother should do and how they should behave, or their confidence about the most desirable parental behavior for the child. Less expressiveness of the cognitive and emotional component may indicate its less manifestation in adolescents' parents' behavior, and thus - less representation in apprehensions about ideal parenthood.

A correlation analysis was performed to identify significant relationships between the cognitive, 
"SOCIALIZATION \& HUMAN DEVELOPMENT" INTERNATIONAL JOURNAL

emotional, and behavioral components of parenthood perceptions within a sample of adolescent boys and girls (table 2).

Table 2. Pearson's correlation coefficient between components of apprehensions about ideal parenthood

\begin{tabular}{|c|c|c|c|c|}
\hline \multirow{2}{*}{$\begin{array}{l}\text { Components of } \\
\text { apprehensions } \\
\text { about parenthood }\end{array}$} & \multicolumn{2}{|c|}{ Cognitive component } & \multicolumn{2}{|c|}{ Emotional component } \\
\hline & $\begin{array}{l}\text { Girls } \\
\mathrm{N}=26 \\
\end{array}$ & $\begin{array}{l}\text { Boys } \\
\mathrm{N}=37 \\
\end{array}$ & $\begin{array}{l}\text { Girls } \\
\mathbf{N}=26\end{array}$ & $\begin{array}{l}\text { Boys } \\
\mathbf{N}=37\end{array}$ \\
\hline Emotional component & $\begin{array}{c}0,376 \\
\mathrm{p} \leq 0,058\end{array}$ & $\begin{array}{l}0,562 * * \\
\mathrm{p} \leq 0001\end{array}$ & & \\
\hline Behavioral component & $\begin{array}{c}0,234 \\
\mathrm{p} \leq 0,251\end{array}$ & $\begin{array}{c}0.521 * * \\
\mathrm{p} \leq 001\end{array}$ & $\begin{array}{c}0,247 \\
\mathrm{p} \leq 0,224\end{array}$ & $\begin{array}{l}0,649 * * \\
\mathrm{p} \leq 0001\end{array}$ \\
\hline
\end{tabular}

The analysis of the data shows that there are no significant correlations between the components of the apprehensions about ideal parenthood within the group of girls, but instead, there are significant correlations between all components of apprehensions about ideal parenthood within the group of boys. This demonstrates the close connection between the components of boys' apprehensions about ideal parenthood and their interdependence.

The Student's t-test for the independent samples was applied to test the statistical significance of differences in the expressiveness of the components of apprehensions about ideal parenthood in the boys' and girls' samples. The results of the analysis are presented in table 3 .

Table 3. Significance of the differences in expressiveness of components of apprehensions about ideal parenthood

\begin{tabular}{|c|c|c|c|c|c|}
\hline \multirow{2}{*}{$\begin{array}{c}\text { Components of } \\
\text { apprehensions }\end{array}$} & $\begin{array}{c}\text { The Livin's criterion } \\
\text { for equality of } \\
\text { variations }\end{array}$ & t-test & $\begin{array}{c}\text { The } \\
\text { difference in } \\
\text { average }\end{array}$ & $\begin{array}{c}\text { Significance } \\
\text { level }\end{array}$ \\
\cline { 2 - 3 } & $\mathbf{F}$ & Significance & & & \\
\hline Cognitive & 3,494 & 0,07 & $-1,81$ & $-5,08$ & 0,075 \\
\hline Emotional & 2,460 & 0,12 & $-2,12$ & $-3,88$ & 0,038 \\
\hline Behavioral & 0,069 & 0,794 & $-2,947$ & $-6,95$ & 0,005 \\
\hline
\end{tabular}

As table 3 shows, significant differences in the expression of the emotional and behavioral components of perceptions about parenthood among boys and girls were discovered. Thus, girls, unlike boys, understand ideal parents significantly more emotionally involved in the process of interaction with the child, in the educational process, those who have more corresponding parenting skills.
Comparing these results with the correlation analysis data described above, we can assume that boys' apprehensions about parenthood are not only less formed in terms of their behavioral and emotional component, but also less differentiated compared to girls' perceptions.

Differences between girls and boys were also found in the analysis of the results of the composition about future 
parenthood. Thus, $39 \%$ of the respondents demonstrated a positive emotional background of the work, most of whom $(72 \%)$ were girls. Instead, boys dominate in the study groups, where the relationship with the child is described emotionally neutral, ambivalent, negative or not described at all. Thus, the domination of neutral emotional background or the presence of formal responses characterized the compositions of $37 \%$ of respondents, including $78 \%$ of boys and $22 \%$ of girls. An ambivalent description of future parenthood was observed in $5 \%$ of the total sample (66.5\% boys and $33.5 \%$ girls). Negatively colored answers, indicating reluctance to have a baby have the same distribution of responses. The absence of any answers about themselves as a parent and about their future child was found in $14 \%$ of the sample, including $89 \%$ boys and only $11 \%$ girls.

All discovered differences in perceptions about parenthood are expected, but their nature causes anxiety in the context of preparing young people for parenthood. Yes, it can be expected that the poverty, the narrowing of the boys' apprehensions about parenthood, which also have a negative emotional coloring, can cause further difficulties in accepting the role of the father.

Analysis of the exact meaning blocks of the «Composition about future parenthood» gives an opportunity to analyze the content of modern adolescents' perceptions about parenthood. The apprehensions about future child include a description of their hobbies, expected personal traits (both positive from a teenager's point of view and negative ones), and concerns about the child. Among the apprehensions about a future child's hobbies, on the first place are the statements about the child's ability to choose what he likes, ability to dedicate time to his own wishes. The second position is divided between training and sports. A complete list of apprehensions about child's hobbies is presented in table 4.

Table 4. Rating of characteristics of the future child by the results of the analysis of "Composition about parenthood"

\begin{tabular}{|c|c|c|c|}
\hline Child's interests & Positive qualities of a child & $\begin{array}{c}\text { Negative qualities } \\
\text { of a child }\end{array}$ & $\begin{array}{l}\text { The biggest fears } \\
\text { about the child }\end{array}$ \\
\hline $\begin{array}{l}\text { 1) A child should } \\
\text { choose his own } \\
\text { hobbies and } \\
\text { interests } \\
\text { 2) Education. } \\
\text { Sport } \\
\text { 3) Communication } \\
\text { with his/her } \\
\text { family and } \\
\text { friends } \\
\text { 4) Creativity } \\
\text { 5) Learning } \\
\text { foreign } \\
\text { languages; Self } \\
\text { development }\end{array}$ & $\begin{array}{l}\text { 1) A sense of happiness } \\
\text { 2) Kindness } \\
\text { 3) Mind } \\
\text { 4) Purposefulness, success, } \\
\text { confidence, diligence } \\
\text { 5) Communication skills, } \\
\text { openess, friendlyness } \\
\text { 6) Culture, manners, politeness } \\
\text { 7) Sincerity, honesty } \\
\text { 8) Joy, cheerfulness, sense of } \\
\text { humor } \\
\text { 9) Autonomy } \\
\text { independence } \\
\text { 10) Ability to stand up for } \\
\text { themselves } \\
\text { 11) Determination, courage }\end{array}$ & $\begin{array}{l}\text { 1) Disobedience } \\
\text { 2)Selfishness, } \\
\text { laziness } \\
\text { 3) Failure to study, } \\
\text { closing in } \\
\text { themselves, } \\
\text { falsehood } \\
\text { indifference }\end{array}$ & $\begin{array}{l}\text { 1) Drug addiction, } \\
\text { alcoholism, } \\
\text { smoking, } \\
\text { friendship with } \\
\text { "bad company" } \\
\text { 2) Diseases } \\
\text { 3) Homosexuality }\end{array}$ \\
\hline
\end{tabular}


"SOCIALIZATION \& HUMAN DEVELOPMENT" INTERNATIONAL JOURNAL
12) Responsibility
13) Humanity
14) Restraint, peace, depth
15) Adequacy

As we can see from the table 4, among the desirable personal characteristics of the future child, the feeling of happiness is most commonly named. Kindness is next in importance, and in the third place is mind. In general, the number of positive traits is much greater than the number of negative traits of the future child, as well as the future probable problems, which are associated with it (Table 4). Probable drug addiction, alcoholism, smoking, friendship with a "bad company" are the biggest concerns about their future child among teenagers. Possible diseases are on the second place.
And several male respondents expressed fears about their child's homosexuality.

The analysis of apprehensions about relationships with children in the future family shows that most of the respondents want to see them as good, friendly, trusting, sincere, open and loved. Several respondents have noted that they wished to have relationship with their future child not similar to those, which they have with their own families, or they want it to be better. Also some single characteristics - such as equal and free, soft and understanding, warm, harmonious were also named.

Table 5. Rating of perceptions about relationships in the future family and joint affairs with the child

\begin{tabular}{|l|l|}
\hline Perceptions about relationships in the future & \multicolumn{1}{c|}{ Joint affairs } \\
family & 1) Spending time together \\
\hline 1) Good & 2) Conversations \\
2) Friendly & 3) Walking \\
3) Trusting & \\
4) Normal & \\
5) Not like with their own parents
\end{tabular}

Among joint affairs with their future child young people generally speak about spending time together without any specific activities. Also, among the common activities they name conversations with child, namely sharing secrets, talking honestly, and sharing everything as if they are friends. Walking is also an important common activity. Rarely answers are: to play together, to have common interests, to do one thing, to travel, to spend evenings together, to play sports.
$92 \%$ of the respondents emphasize the importance of friendly, trusting, open relationships with the child, they point how important a respect is for each other and understanding. It is also important that the child should not be ashamed of his parents, a child should be proud of them.

Regarding the description of themselves as a future father / future mother, the lowest number of respondents' responses was recorded here. Some respondents point out that they feel happiness and pride when they are thinking about a future baby, they are dreaming of 
several children and a strong family. Available descriptions often also reflect fears and anxieties about potential parenthood, marking their incompetence, fears of failing to cope with the role of "good father" or "good mother", and feeling that they will not be able to find a common language with their child. But many teenagers respond that they do not even think about future parenthood.

\section{Disscusion}

According to the researchers, during adolescence period there is a certain duality of the parent sphere and ideas about themselves as a father / mother. (Ovcharova, 2005; Filippova, 2002). On the one hand, researches show the high value of family for young people of 14-18 years, at the same level with the value of "love" and "health". 72.5\% of respondents choose family as the most important value, which indicates its priority in the structure of young people's vital values. But, on the other hand, some teenagers express a bright negativity about future family life. Researches show that they often have an uncertain, sometimes neglectful, type of parental position. They have incomplete knowledge of importance and necessity to take into account such areas of parenthood as the personal qualities of parents; skills and practice of upbringing, knowledge about patterns of development of the child; the image of father/mother can be not sufficiently balanced about the components of parenthood (cognitive, emotional, behavioral). Many adolescents can be characterized by the lack of selfconfidence; partial acceptance of themselves; uncertainty in others evaluation of themselves; they need support from others. They usually have unformed goals of their lives or they can have some manifestations of situational activity or passive anticipation of the situation.

The findings from our study on the structure of parenthood apprehensions among adolescent boys partially correlate with the study of Petrosiants V.R. and Lytkina P.E. (Petrosiants, \& Lytkina, 2017), who studied ideas of young men of 18-23 years old. Scientists note that the brightest is the behavioral component of parenthood apprehensions. The second place takes the cognitive component; and the last is the emotional one.

Comparing the results, which were received by the method "The composition about parenthood" with the study by S.A. Abdullina, it can be stated that people that were interviewed show more responses with positive emotional background of composition (39\% vs. 16.1\%), neutral background (37\% vs. $17.7 \%)$, and also the major number of composition with negative emotional background (5\% vs. $1.6 \%$ ) (Abdullina, 2018). Besides, $5 \%$ of the compositions, which were received in our study, have an ambivalent emotional background; this category of answers in the Abdullina's study is not presented. Comparison of the rating of characteristics of the future child shows that the list of qualities, which were named by young people, corresponds with each other in both studies. Thus, Russian teenagers note the following (in order of decreasing frequency) as: kindness, mind, independence, beauty, success, purposefulness, health, friendliness, happiness, individuality, sensitiveness, respectability, honesty, modesty, manners, and talent. However, their answers do not present the negative characteristics of the future child, as it is presented in our study. But the adolescent's vision about hobbies of their future child slightly differs: 
therefore, the first place in our study takes the answer "the child should choose his/her own hobbies"(see table 4). But in Abdullina's study there is no such answer, which probably reflects an orientation to the democratic style of upbringing.

\section{Conclusion}

As a result of the research, the features of adolescent's apprehension about future paternity were revealed, particularly, the content and representation of the cognitive, emotional and behavioral components of these ideas among boys and girls. It was found that the hierarchy of representation of main conceptions among young boys and girls is similar with dominance of the behavioral component. This can point out the greater awareness about parent's skills and competences, compared to the representation of the child's image and feelings related to the parental role.

Also gender differences in the structure and level of expression of main conceptions of paternity were revealed. Therefore, if we compare boys versus girls, the components of the concept are interrelated, interdependent. Girls have a significantly higher level of formation of the behavioral and emotional component of ideas. This can prove that these conceptions about future parenthood will help them to be more emotionally involved parents into the process of interaction with the child and into the educational process, those who will have better parenting skills.

The content of teenager's perceptions of parenthood was revealed, especially the image of their future child and the image of relationships in the future family, and their own perceptions about themselves as future mother/father. It was revealed that adolescent's perceptions about themselves as future mother/father are least represented in the descriptions of respondents. They are often associated with ambivalent feelings, either reflecting joy and pride when thinking about having a baby, or fears about potential parenthood. Teenagers often worry about their own incompetence. They fear not to be able to cope with the roles of "good mother" or "good father."

Significant differences were found in the content of adolescent's perceptions of ideal parenting, their structure, depending on gender: if these ideas are quite often for girls, and mostly often they are positively emotionally colored, then most of the boys have not formed ideas and often they have a neutral, ambivalent, or negative emotional color.

The prospect of further research is to examine the relationship between teenagers' perceptions of parenthood with the nature of the child-parent relationship, as well as developing psycho-educational and psycho-corrective programs, aimed either at optimizing real child-parent relationships, or at correcting teenagers' stereotypical perceptions of family and parenthood.

\section{References}

Abdullina, S.A. (2018) Predstavlenyia o rodytelstve u detei doshkolnoho, mladsheho shkolnoho i podrostkovoho vozrasta (Dys. kand. psykhol. nauk). Avtonomnaia nekommercheskaia orhanyzatsyia vyssheho obrazovanyia "Moskovskyi humanytarnyi uniersytet". [Parenthood apprehensions in preschool children of primary school and adolescence]. Moscow. (Russian)

Zakharova E.Y. (2017) Rodytelstvo kak vozrastno-psykholohycheskyi 
fenomen (Dys. dokt. psykhol. nauk) [Parenthood as an age-psychological phenomenon].

Moskovskyi hosudarstvennyi universytet im. M.V.Lomonosova. Moscow. (Russian)

Meshcheriakova, S.Yu. (2002) Put k materynstvu nachynaetsia $\mathrm{s}$ mladenchestva. [The path to motherhood begins with infancy] Doshkolnoe vospytanye, 11, 81-89. (Russian)

Ovcharova, R.V. (2005) Psykholohyia rodytelstva [Psychology of Parenthood]. Moscow: Yzd-vo: Akademyia. (Russian)

Pavlova, T.V. (2012) Psykholohycheskie determynanty formirovania predstavlenyi lichnosti o roditelstve (Dys. kand. psykhol. nauk) [Psychological determinants of the formation of the person's ideas about parenthood]. Rossyiskyi unyversytet druzhby narodov. Moscow. (Russian)

Petrosiants, V.R., Lytkina, P.E. (2017) Struktura predstavlenyi ob idealnom roditele u yunoshei-studentov VUZa [The structure of apprehensions about the ideal parent of young students of the university]. Universum: Psykholohyia $y$ obrazovanie: elektron. nauchn. zhurn. 2(32). URL: http://7universum.com/ru/psy/archiv e/item/4286 (дата обращения: 18.03.2020).

Filippova, H.H. (2002) Psykholohyia materynstva: uchebnoe posobie. [The Psychology of Maternity: A Study Guide]. Moscow: Izd-vo Instytuta psykhoterapii. (Russian)

Yablonska, T. M., Bulatevych, N. M., Mambetova, A. A. (2019) Obrazy idealnykh batkiv yak skladova chastyna uiavlen pro batkivstvo $\mathrm{v}$ yunatskomu vitsi: etnopsykholohichni osoblyvosti. [The images of ideal parents as a component of apprehensions of parenthood in the youth: ethnopsychological features]. Teoriia $i$ praktyka suchasnoi psykholohii, 6(2), 142-147. DOI https://doi.org/10.32840/26636026.2019.6-2.25 (Ukrainian)

Chan, H.W., Tam, K.P. (2016) Understanding the Lack of ParentChild Value Similarity. The Role of Perceived Norms in Value Socialization in the Immigrant Families. Cross-cultural Psychology, 47(5), 651-669. DOI: 10.1177/0022022116635744

Lindsey, S. Aloia \& Claire Strutzenberg (2019)

Parent-Child Communication Apprehension: The Role of Parental Alienation and SelfEsteem. Communication Reports, 32 (1), 1-14. DOI: $\underline{10.1080 / 08934215.2018 .1514641}$ 


\title{
PECULIARITIES OF THE RELATED TYPE OF MOTIVATION AND ACADEMIC SUCCESS OF STUDENTS: CROSS-CULTURAL ASPECT
}

https://doi.org/00.00000/SHDISJ-00-0.0-0000

Zapeka Yana,

ORCID ID: 0000-0002-3412-3629

Su Fey,

ORCID ID: 0000-0002-6772-0921

Lilia Sirocha

ORCID ID: 0000-0003-1033-8075

\begin{abstract}
The purpose of the article is to present the results of the study of the relationship between the type of motivation of academic activity with the academic achievement of Ukrainian and Chinese students and identify cultural differences.

Research methodology. In order to find out the cultural characteristics of academic motivation and academic achievement of students, the sample included 30 Ukrainian and 30 Chinese students. We used the following diagnostic methods as: a questionnaire "Studying the motives of students' educational activity" (modified by A.O. Rean, V.O. Yakunin); a questionnaire «Diagnostics of students' educational activities by A.O. Rean, V.O. Yakunin» (in the modification of N.T.Badmayeva); a questionnaire « Learning the motivation of studying in higher educational institutions » (by T.I. Ilyina).

Results of the research. The received results show that there are differences in the indicators of the educational motivation of Ukrainian and Chinese students. Thus, unlike Chinese students, Ukrainians are more driven by external motives (getting a diploma), while Chinese students - with internal and gnostic motives (acquiring knowledge, mastering the profession). According to the results of correlation analysis, we can say that the internal and cognitive motives of the educational activity (acquiring knowledge, mastering the profession) directly relates with the interest in the profession and satisfaction of the chosen professional career (professional motives, motives of creative self-realization, educational and cognitive motives, communicative and social motives). The average score of the exam session has a direct correlation with the motivation for creative self-realization.

Discussion. It is shown that since Ukrainian students, unlike Chinese, can be characterized by external motivation to study, it is necessary for educational socialization to focus on the formation and development of the student's personality and nurturing independence and mature, subjective, and active life position.
\end{abstract}

Keywords: motivation of academic activity, academic achievement, adolescence, cultural dimension, socialization of personality.

\section{Introduction}

The modern world is becoming increasingly global and can be characterized by such features as variability, uncertainty, and increased stress. A famous Israeli historian and futurologist Y. N. Harari predicts that in the coming decades, due to the increasing technological development of society and the algorithmization of a large number of 
processes, the role of man in various professional fields will be radically reconsidered (Harari, 2018). Moreover, due to the emergence of some professions and the disappearance of others, a person will be forced to adapt to such changes. The Russian specialist in the field of personality psychology O.G. Asmolov, continuing this view, points out that now it is worth talking not about the process of human adaptation to changes, but rather about the process of "pre-adaptation". This process is an individual's ability to foresee changes and be ready for future events (Asmolov, 2015). According to the authoritative Ukrainian researcher in the field of developmental and pedagogical psychology O.I. Vlasova, in modern education there has already been a transition from the paradigm of knowledge to the paradigm of competence. According to the competency approach, the criterion for the success of learning is mastering competencies. We mean that it is the students' ability to apply knowledge and skills in practice. And one of the main tasks of modern institutions of higher education is the formation of students' competence of self-education, without which successful educational and professional activity is impossible (Vlasova, 2015). This task arises as a practical necessity, taking into account the fact of the credit-module system of education. According to this system, most of the study material the student has to study and master independently. These conditions are fixed in many documents that regulate the requirements for the organization of the current educational process. In this regard, it is necessary to point out the relevance of the thesis of lifelong learning. It is necessary to form the students' readiness to design and implement their own trajectory of educational activities throughout their professional careers All these will ensure the success of the individual in social and professional life.

At the macro level, educational institutions and other cultural and social institutions provide the process of socialization of the individual, entry of a young person into the world of culture, learning of patterns of behavior in society, systems of roles, and social statuses. Nowadays either education or personality experiences the active influence of information technologies (Internet, virtual reality, media, social networks, etc.) and change of vectors in the values of the individual. As an example, we can point out characteristic differences according to the theory of three generations $(\mathrm{x}, \mathrm{y}, \mathrm{z})$. This escalates the problem of communication between generations in the field of education, which turns out in topical issues that are often discussed in modern forums and conferences: "What to teach?", "What will be useful and necessary in the future?", "How to teach?" However, let's not forget that a very important role in academic success is played by the student's attitude to the learning process and knowledge, his interest in learning and his conscious need to acquire knowledge. Therefore, an important and urgent task of higher education is the formation and development of students' positive motivation for learning. Therefore, the aim of our research is to study the relationship between the type of motivation and academic success and finding out the impact of cultural characteristics on the learning process of the individual, using the example of Ukrainian and Chinese students. 


\section{Theoretical framework}

Many studies of domestic and foreign scientists are devoted to the problem of the success of the educational activity of students. One of the main determinants of success is the activity of the individual in achieving the goal. We mean that learning is not possible without a conscious goal to acquire certain knowledge, skills, and abilities. In the activity of learning a person reproduces not only knowledge and skills, but also the ability to learn, that is the ability to selfdevelopment as a subject of life. Therefore, the result of successful learning is also a positive dynamic of the personal development of the user of educational services. In educational activity, not only cognitive functions are combined, but also the needs, motives, emotions, and will of the learner. Studies of psychological and pedagogical aspects of student activity conducted by V.O. Yakunin indicate that the level of educational activity does not yet determine the student's academic achievements. According to the scientist's point of view, such core characteristics as intelligence and motivational orientation of the personality play a bigger role in the academic success (Yakunin, 1998) The impact of abilities on academic performance is not so simple, because a lot of depends from what exact place specific abilities occupy in the personality structure of a particular student, in the system of his life values. However, the author considers the connection between the academic success of students and special abilities, which are crucial for the development of professionally important qualities, to be unambiguous. The educational activity of students differs in its professional orientation and, accordingly, it differs with its increasing importance of professional motives for self-education.

So, it is obvious that a certain level of cognitive abilities and individualtypological features of the student can contribute to the effective acquisition of competencies. But, in many cases not only cognitive abilities and level of intelligence are important for successful learning, but mostly personal, motivational, and value characteristics, which are responsible for their successful use (Gordeeva, Osin, 2012).

In the process of receiving the higher education, the psychological basis of professional activity is formed. Therefore, a very important role in the formation of the individual as a professional has the period of entering into educational and professional activities. Motivation plays a significant role at this stage because the future study of the student depends on the motivation of the student to get a profession.

A motive - is the main driving force in the study of any educational subject. The human educational activity is carried out for it. Objects of the outside world, ideas, thoughts and experience, that is, what the need embodied - all these can be motives. Learning motivation is a complex and dynamic mental construct. It contains some components (meanings, motives, goals, interests) and it is manifested in a specific activity - learning. There are external and internal factors, which influence the motivational sphere of the student's personality. Internal psychological factors include: individual-typological features of personality, a potential of personality, its thirst for knowledge, a need for selfaffirmation and recognition, self-education skills, an achieved level of selfdevelopment, etc. And external 
"SOCIALIZATION \& HUMAN DEVELOPMENT" INTERNATIONAL JOURNAL

psychological factors include: the level of prestige, wages, the importance in the labor market, etc.

The structure of learning distinguishes the actual motives of learning and professional motives, which determine the direction of human activity and orientation in professional activities. Professional motivation is an internal driver of development and professionalism as a personal neoplasm and the individual as a whole. It provides the development of professional education and the culture of the individual.

According to A.A.Markova, in the process of receiving the higher education, learning motivation consists of two groups of motives - educational - professional and social. At the same time, until the end of students' study from the group of educational and professional motives should be formed motives of professional self-education. And from the group of social motives should be formed motives of professional cooperation (Markova, 1990).

Learning activity is always motivated by the fact that there are several sources of student activity - personal, internal and external. Personal sources of activity are interests, needs, attitudes, standards and stereotypes. All these determine the desire for self-realization and self-improvement. Internal sources of learning motivation include cognitive and social needs.

$\begin{array}{ccc}\text { External } & \text { sources of learning } \\ \text { motivation } & \text { include } & \text { expectations; }\end{array}$
requirements for compliance with social norms of behavior, communication and activities; and opportunities as objective conditions that are necessary for the development of educational activities. Different cultural peculiarities (western or eastern culture) also affect attitudes in the structure of personality and the selfconcept of students and their motivation (for example, the focus on success and high achievements is the feature of Western culture, which is embodied in the worldview of the individual). That is, the type of culture of the country affects human behavior, including his professional selfdetermination, and business activity.

In the context of discussing the research topic, it is necessary to consider the problem of learning motivation through the prism of the well-known typology of cultural dimensions by G. Hofstede. The system of personal values is formed in the process of socialization (in the family, schools, at work) and it differs in masculine and feminine cultures. The person's worldview begins to form in the family, and cultural stereotypes that are accepted in society are based. Hofstede's research shows that in masculine cultures children are taught ambition, contest, and a desire to become better, to succeed through their own efforts. Leaders and the best pupils, students are most valued in educational institutions (Reynolds, Valentine, 2014). On the contrary, in feminine cultures children are taught modesty, obedience, maintaining harmonious relationships with others, observance of moral and ethical norms of behavior. In schools, pupils and students do not try to be different from others, they do not strive to achieve high results because the main thing is to learn how to adapt to society and maintain good relations in the team.

The type of culture also influences which specialties students choose when they enter higher education institutions. In masculine countries, specialties are divided depending on what type of behavior is specific to a particular gender (women often choose pedagogy, and men - law and 
engineering). Students choose their future profession on the basis of future income or obvious benefits. In feminine countries, the social roles of men and women do not differ. Approximately the same number of men and women study in the same specialties. The choice of future profession is more influenced by interest in a particular subject, rather than by the desire for money (Reynolds, Valentine, 2014.).

\section{Research design and survey sample}

To study the peculiarities of the relationship between the type of motivation of educational activities with the academic success of students, we interviewed 60 students (30 Chinese students and 30 Ukrainian students), which formed two groups for comparison. We used the following diagnostic methods as: a questionnaire "Studying the motives of students' educational activity" (modified by A.O. Rean, V.O. Yakunin); a questionnaire «Diagnostics of students' educational activities by A.O. Rean, V.O. Yakunin» (in the modification of N.T.Badmayeva); a questionnaire «Learning the motivation of studying in higher educational institutions») (by T.I. Ilyina) (Karelin, 2007). In our study, we have also used a scale to evaluate one's satisfaction with academic success and indicators of the level of academic achievement in the form of the average score for the semester (based on selfreport).

We have used such quantitative methods of mathematical processing and data analysis with the use of a package of SPSS 17.0 as: k-means method, calculation of standard deviation and normal distribution, Spearman's correlation coefficient, Student's t-test.

\section{Results}

Analysis of the results of the questionnaire «Learning the motivation of studying in higher educational institutions» (by T.I. Ilyina) included a comparison of averages between groups of Ukrainian and Chinese students according to Student's ttest for independent samples. We found that the indicators on the scales "acquisition of knowledge", "mastery of the profession" and "getting a diploma" differ significantly (tabl.1).

Table 1. Comparative statistics of groups of Ukrainian and Chinese students according to the questionnaire

«Learning the motivation of studying in higher educational institutions » (by T.I. Ilyina)

\begin{tabular}{|l|l|c|c|c|}
\hline \multirow{2}{*}{ Scale } & \multicolumn{1}{|c|}{ Students } & $\mathbf{N}$ & Average value & $\begin{array}{c}\text { Standard } \\
\text { deviation }\end{array}$ \\
\hline \multirow{2}{*}{ Acquisition of knowledge } & Ukrainian & 30 & $8,7^{* *}$ & 1,618 \\
\cline { 2 - 5 } & Chinese & 30 & $10,5^{* *}$ & 1,661 \\
\hline \multirow{2}{*}{ Mastery of the profession } & Ukrainian & 30 & $5,8^{*}$ & 1,661 \\
\cline { 2 - 5 } & Chinese & 30 & $7,3^{*}$ & 3,161 \\
\hline \multirow{2}{*}{ Getting a diploma } & Ukrainian & 30 & $6,5^{*}$ & 3,161 \\
\cline { 2 - 5 } & Chinese & 30 & $8,0^{*}$ & 1,611 \\
\hline
\end{tabular}

$*$ - $\mathrm{p}<0,05, * *-\mathrm{p}<0,001$ (Student's t-test for independent samples)

Chinese students have higher scores on the scales of mastering the profession and acquiring knowledge, and Ukrainian students - on a diploma scale. This indicates a greater manifestation of curiosity, the desire to acquire professional knowledge and form important professional qualities among Chinese students during their education. If we are talking about Ukrainian students - the focus 
on formal receiving of the diploma is dominant.

Analysis of results of the questionnaire 'Diagnostics of students' educational activities by A.O. Rean, V.O. Yakunin" (in the modification of N.T.Badmayeva) also showed significant differences for groups of Chinese and Ukrainian students on the scales "communicative motives", "avoidance motives", "professional motives", "motives of creative self-realization", "educationalcognitive motives" and "social motives" (table 2).
Chinese students have higher scores on all scales except the "avoidance motives" scale. The data show that Chinese students are primarily guided by internal educational and cognitive motives, professional motives, and motives of creative self-realization as the leading motives of educational activities. In the second place, they have communicative and social motives. In Ukrainian students, on the other hand, the external motive for avoiding failure was more pronounced. No significant differences were found between the groups on the scale of "prestige motives".

Table 2. Comparative statistics of groups of Ukrainian and Chinese students according to the questionnaire "Diagnostics of students' educational activities by A. O. Rean, V. O. Yakunin" (in the modification of N. T. Badmayeva)

\begin{tabular}{|l|l|c|c|c|}
\hline \multicolumn{1}{|c|}{ Scale } & \multicolumn{1}{|c|}{ Students } & $\mathbf{N}$ & Average value & $\begin{array}{c}\text { Standard } \\
\text { deviation }\end{array}$ \\
\hline \multirow{2}{*}{ Communicative motives } & Ukrainian & 30 & $3,5^{*}$ & 0,809 \\
\cline { 2 - 5 } & Chinese & 30 & $3,9^{*}$ & 0,857 \\
\hline \multirow{2}{*}{ Avoidance motives } & Ukrainian & 30 & $3,3^{*}$ & 0,788 \\
\cline { 2 - 5 } & Chinese & 30 & $2,8^{*}$ & 0,866 \\
\hline \multirow{2}{*}{ Motives of prestige } & Ukrainian & 30 & 3,5 & 0,792 \\
\cline { 2 - 5 } & Chinese & 30 & 3,6 & 0,795 \\
\hline \multirow{2}{*}{ Professional motives } & Ukrainian & 30 & $4,0^{*}$ & 0,795 \\
\cline { 2 - 5 } & Chinese & 30 & $4,6^{*}$ & 0,818 \\
\hline \multirow{2}{*}{$\begin{array}{l}\text { Motives of creative self- } \\
\text { Eealization }\end{array}$} & Ukrainian & 30 & $3,8^{*}$ & 0,790 \\
\cline { 2 - 5 } Educational-cognitive motives & Chinese & 30 & $4,4^{*}$ & 0,813 \\
\cline { 2 - 5 } & Ukrainian & 30 & $4,0^{*}$ & 0,795 \\
\hline \multirow{2}{*}{ Social motives } & Chinese & 30 & $4,6^{*}$ & 0,790 \\
\cline { 2 - 5 } & Ukrainian & 30 & $3,8^{*}$ & 0,813 \\
\hline
\end{tabular}

$*-\mathrm{p}<0,05, * *-\mathrm{p}<0,001$ (Student's t-test for independent samples)

Thus, the received results make it possible to state the difference in the indicators of educational motivation of Ukrainian and Chinese students. Thus, unlike Chinese students, Ukrainians are more guided by external motives, and Chinese students are guided by internal ones.

To determine the relationship between the learning motivation scales in the sample as a whole, we performed a correlation analysis using the Spearman correlation coefficient and a two-way significance criterion. It was found that the indicator of "knowledge acquisition" has a direct correlation with the scales of "mastery of the profession" $(\mathrm{r}=0.712$; $\mathrm{p} \leq 0.01)$, "communicative motives" $(\mathrm{r}=$ $0.630 ; p \leq 0.01)$, "professional motives" ( $\mathrm{r}$ $=0.633 ; \mathrm{p} \leq 0.01)$, "social motives" $(\mathrm{r}=$ $0.633 ; p \leq 0.01)$, "motives of creative selfrealization" $(\mathrm{r}=0.633 ; \mathrm{p} \leq 0.01)$ and 
"SOCIALIZATION \& HUMAN DEVELOPMENT" INTERNATIONAL JOURNAL

"educational-cognitive motives" $(\mathrm{r}=0.633$; $\mathrm{p} \leq 0.01)$. On the contrary, the indicator "knowledge acquisition" has an inverse correlation with the indicators of "getting a diploma" $(\mathrm{r}=-0.608 ; \mathrm{p} \leq 0.01)$ and "avoidance motives" $(\mathrm{r}=-0.637 ; \mathrm{p} \leq 0.01)$. Therefore, the thirst for knowledge and curiosity are directly related to the development of internal learning motives.

The indicator "mastery of the profession" has a direct correlation with the scales "communicative motives" $(\mathrm{r}=$ 0.684; $\mathrm{p} \leq 0.01$ ), "professional motives" ( $\mathrm{r}$ $=0.736 ; \mathrm{p} \leq 0.01)$, "motives of creative self-realization" $(\mathrm{r}=0.736 ; \mathrm{p} \leq 0.01)$, "educational-cognitive motives" $(\mathrm{r}=0.736$; $\mathrm{p} \leq 0.01)$ and "social motives" $(\mathrm{r}=0.736$; $\mathrm{p} \leq 0.01)$. On the contrary, the indicator "mastery of the profession" has an inverse correlation with the indicators of "getting diploma" $(\mathrm{r}=-0.685 ; \mathrm{p} \leq 0.01)$ and "motives for avoiding failure" $(\mathrm{r}=-0.716$; $\mathrm{p} \leq 0.01)$. The received correlations confirm that the internal motives of educational activity are directly interrelated with interest in the profession and satisfaction with the chosen professional path.

The indicator "getting a diploma" has a direct correlation only with the "motive to avoid failure" ( $\mathrm{r}=0.810$; $\mathrm{p} \leq 0.01)$. On the contrary, the indicator "mastery of the profession" has an inverse correlation with the scales "social motives" $(\mathrm{r}=-0.811 ; \mathrm{p} \leq 0.01)$, "educational and cognitive motives" $(\mathrm{r}=0.811 ; \mathrm{p} \leq 0.01)$, "professional motives"( $\mathrm{r}=-0.811$; $\mathrm{p} \leq 0.01)$ and "communicative motives "( $\mathrm{r}$ $=0.794 ; \mathrm{p} \leq 0.01)$. These correlations indicate that those students who are more driven by external motives that are related to a formal attitude to the profession, they are guided not by motives of professional development, but they rather try to avoid failure. They focus on the assessment of others and follow the way of least resistance.

The average score of the creditexamination session has an inverse correlation with the motivation to avoid failures, and vice versa has a direct correlation with the motivation of creative self-realization. This may indicate that the motives for creative self-realization are supported by the desire to devote more time to their work and to develop as a professional, and the desire of selfimprovement, which has a positive effect on academic success.

The results of comparing the averages between the groups of Ukrainian and Chinese students showed that, while for Chinese students the focus is on "acquiring knowledge", Ukrainian students are more focused on "getting a diploma". This is confirmed by the distribution of motives by the questionnaire "Studying the motives of students' educational activity" (modified by A.O. Rean, V.O. Yakunin); where students were offered 16 motives, and they had to evaluate each of them on the basis of significance from 1 to 7 points. The results were processed by determining the frequency of mentioning the motives as the most significant in the whole sample. Based on the received results, the rank of the motive was determined. This allowed us to build a hierarchy of motives for Chinese and Ukrainian students. The five most important learning motives in each group were selected for analysis.

Ukrainian students consider such motives as more priority as: to successfully study, continue their study and fulfill pedagogical requirements, not to be worse than their classmates, to get approval from parents and others. The nature of these motives is more focused on the process of 
"SOCIALIZATION \& HUMAN DEVELOPMENT" INTERNATIONAL JOURNAL

activity in the short term and the dominance of external motives.

Chinese students have shown a greater focus on the desire to become a highly qualified specialist; they want to get intellectual pleasure, they have a desire to gain the respect of teachers, successfully study and receive a diploma. Therefore that indicates the dominance of internal, more mature professional motives for learning, focus on long-term results, focus on the work in the specialty, social utility, and development of professional competencies. It can be assumed that Chinese students are more aware of why they need knowledge and how they will be able to use it in the future.

We also compared the average scores of the methods used according to gender. It is interesting that the leading motive for the group of men was "mastering the profession". And if we compare the women group - the motives of "getting a diploma" and "acquiring knowledge" were more dominant. This combination of motives may indicate either about satisfaction with the chosen profession or importance for part of the sample of formal consolidation of their status in society. That can mean the importance of higher education.

\section{Discussion}

The results of our study indicate differences in the cultural profiles of learning motivation of Chinese and Ukrainian students and the relationship of motive to creative self-realization with academic success. These results in some way complement the data of the research by L.V. Bondar, in which it is stated that external motives of educational activity really matter for students with low and medium levels of educational motivation.

These external motives are namely the approval of parents, teachers, diplomas, and communicative motives. Also, according to L.V. Bondar, senior students are more willing to work in the specialty and to produce public benefits and acquire professional competencies. According to our study, this is typically only for Chinese students. So, we can assume that Ukrainian students will also have this motivation, but in later courses (Bondar, 2017).

Besides, the results of our study confirm the data of a sociological study by R.K. Malinauskas, which was on a sample of students of Lithuanian pedagogical educational institutions. Such motives as "the desire to expand horizons and erudition" and "the need for constant intellectual development" dominate among the motives for the development of personality. But at the same time, these motives do not differ between junior and senior students. The motives of "selfeducation" and "orientation to new knowledge" prevail among the cognitive motives. This indicates that students of different courses realize the need to study during their lives. According to social motives, the differences between junior and senior students are only based on such motives as "awareness of the need for higher education." This can be explained by the fact that senior students have a better understanding of the needs of the market in specialists. Junior and senior students have internal motivation as the dominating in the structure of motivation. In the second position, fourth-year students have an external positive motivation. The first-year students have an external negative motivation as the most dominant, particularly, the desire to avoid critics from teachers and friends, avoidance of possible punishments, and troubles (Malinauskas, 2005). Therefore, this corresponds to the 
"SOCIALIZATION \& HUMAN DEVELOPMENT" INTERNATIONAL JOURNAL

data of our research, namely the results of a sample of Ukrainian students.

\section{Conclusion}

In our research, we have found significant differences in learning motivation among students from different cultures. Chinese students are primarily guided by the motives associated with the acquisition of knowledge and mastery of the profession, and Ukrainian students are guided by the motive for getting a diploma. This indicates a more mature learning position of Chinese students. We can assume, on the bases of the differences due to cultural and socio-economic conditions of development of countries, that such motivation of Chinese students is formed since school years. It can be due to high competitiveness, diligence, independence and earlier autonomy in relation to the parental family, because of the education in boarding schools. And a more superficial and formal attitude to learning and acquiring professional competencies among Ukrainian students can be explained by more bright crises of professional choice and separation from the parental family. The results of the study reveal that the predictor of academic success may be indicators of learning motivation, in particular, high rates of internal and cognitive motivation. The received results can be used in order to improve the quality of education in higher education institutions and to provide practical advice to curators, which will be useful in educational work with students. In the context of the data covered in the article, it may be promising to check for crosscultural differences at different stages of education of students of different specialties.

Conflict of interests: The authors declare no conflict of interest.

\section{References}

Asmolov A.G. (2015) Psikhologiya sovremennosti: vyzovy neopredelennosti, slozhnosti i raznoobraziya [The Psychology of Modernity: Challenges of Uncertainty, Complexity and Diversity] / A.G. Asmolov. Psikhologicheskiye issledovaniya (elektronnyy zhurnal) [Psychological research (electronic journal)] - T.8. \#40 [in Russian]

Vlasova O.I. (2015) Psykholohiia vyshchoi shkoly : pidruchnyk [Psychology of High school: a textbook] / O.I.Vlasova, V.A.Semychenko, S.Y.Pashchenko, Y.G.Nevidoma / za red. O.I.Vlasovoi. - K. : VPTs «Kyivskyi universytet» [PCP «Kyiv University»], 2015. - 405 p. [in Ukrainian]

Gordeeva T.O. (2012) Osobennosti motivatsii dostizheniya i uchebnoy motivatsii studentov, demonstriruyuschih raznyie tipyi akademicheskih dostizheniy (EGE, pobedyi $\mathrm{V}$ olimpiadah, akademicheskaya uspevaemost) [Features of achievement motivation and educational motivation of students demonstrating different types of academic achievements (USE, victories in olympiads, academic performance)] / T.O. Gordeeva, E.N.Osin.

Psihologicheskie issledovaniya. [Psychological research] - T.5. \#24. P.4. [in Russian]

Bondar L.V. (2017) Osoblyvosti motyvatsii navchalnoi diialnosti studentiv - maibutnikh praktychnykh psykholohiv [Features of motivation of educational activity of students - future practical 
psychologists] / L.V.Bondar. Visnyk Natsionalnoho aviatsiinoho universytetu. Seriia: Pedahohika, psykholohiia [Bulletin of the National Aviation University. Series: Pedagogy, Psychology], Vol. \#10. - 154 p. [in Ukrainian]

Harari Y.N. (2018) 21 urok dlya 21 stolittya [21 lessons for the 21st century] / Y. N. Harari - K.: Book Chef - 416 p. [in Ukrainian]

Karelin A.A. (2007) Bolshaya entsiklopediya psikhologicheskikh testov [Big Encyclopedia of Psychological Tests] / A.A. Karelin - M.: Eksmo - 409 p. [in Russian]

Malinauskas R.K. (2014) Motivatsiya studentov raznyih periodov obucheniya [Motivation of students of different periods of study] /
R.K.Malinauskas

Sotsiologicheskie issledovaniya [Sociological studies] - \#2. - P.134138 [in Russian]

Markova A.K. (1990) Formirovanie motivov ucheniya [The formation of motives for learning] / A.K. Markova, T.A.Matis, A.B.Orlov M.: Prosveschenie - 192 p. [in Russian]

Sana Reynolds, Deborah Valentine (2014). Guide to Cross-Cultural Communication, - $134 \mathrm{p}$.

Yakunin V.A. (1998) Pedagogicheskaya psikhologiya: Ucheb. posobiye/Evrop. in-t ekspertov [Educational Psychology: Textbook/ Europe. Institute of experts.] / V.A.Yakunin - SPb.: Izd-vo "Polius" $-639 p$. 